(1) 

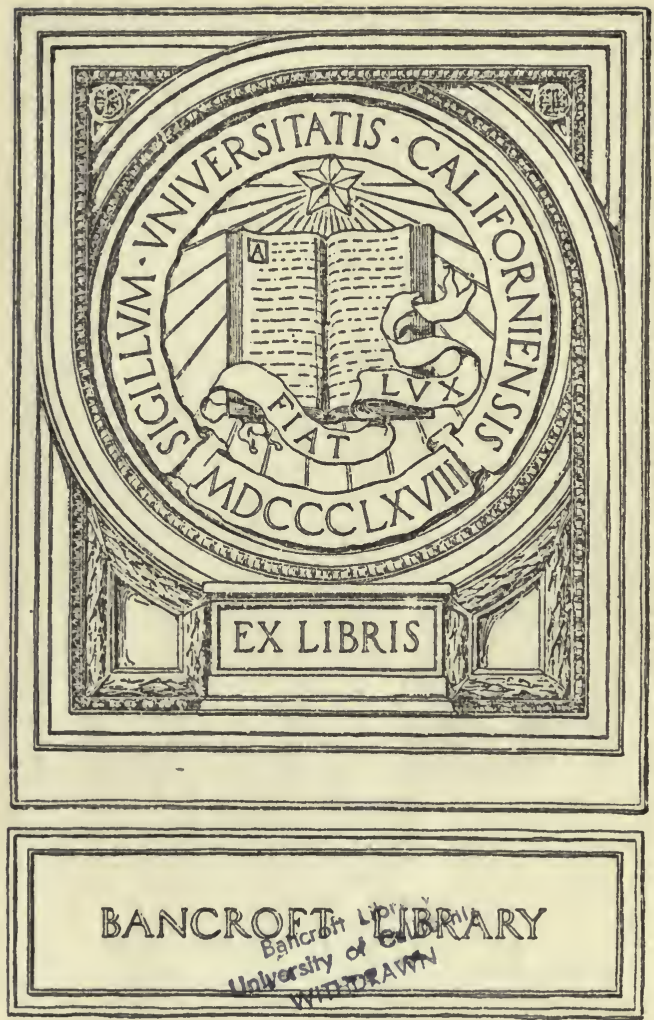




\section{THE ARGENTINE REPUBLIC}




\section{BY PIERRE DENIS}

\section{B R A Z I L}

Translated, and with an Historical Chapter by BERNARD MIALL. With a Supplementary Chapter by DAwSON A. VINDIN, a Map and 36 Illustrations

Cloth, 15/-net. Third Impression

"Altogether the book is full of information, which shows the author to have made a most careful study of the country."-Westminster Gazette.

T. FISHER UNwIN LTiD LONDON 
Digitized by the Internet Archive in 2007 with funding from Microsoft Corporation 


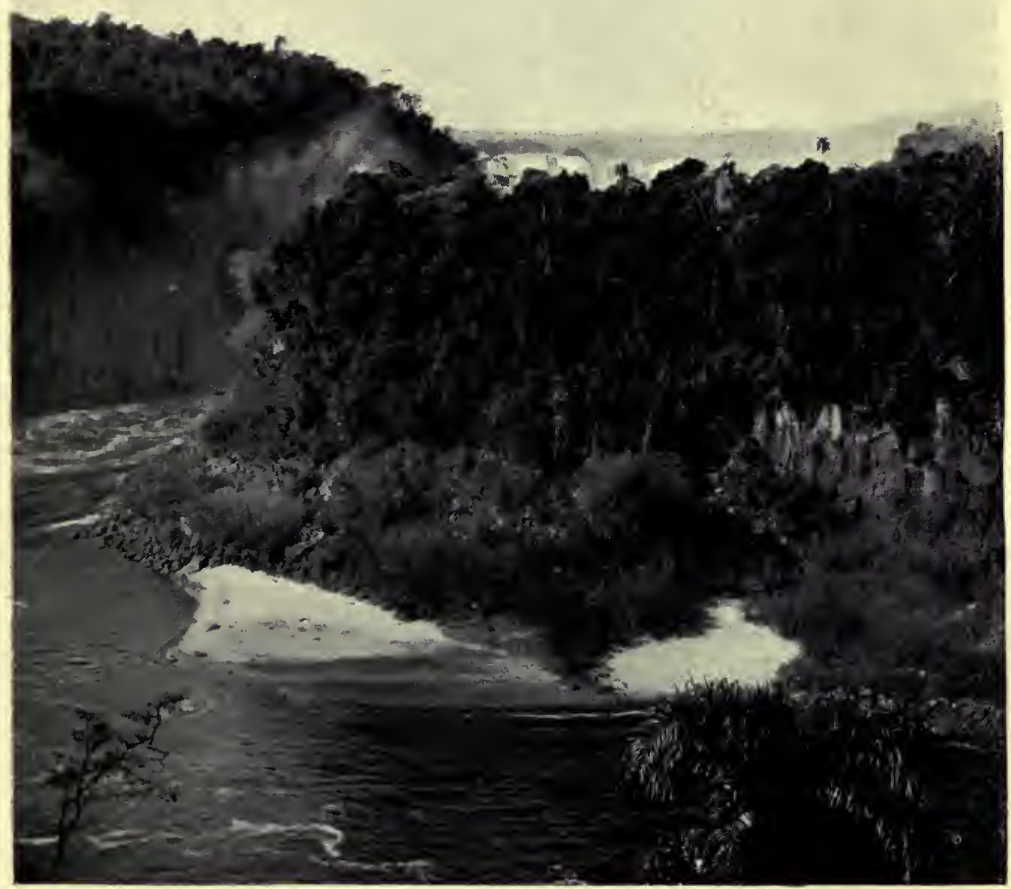

THE FALLS OF THE YGUASSU.

Thirteen miles above the confluence with the Paraná. Like the Parana at the Salto Guayra, the river cuts through a layer of basalt intercalated in the red sandstone. The forest of the province of Misiones has a tropical character near the river. The araucarias cover only the higher parts of the tableland. 


\section{THE ARGENTINE \\ REPUBLIC • ITS DE-}

VELOPMENT AND PROGRESS By PIERRE DENIS, D. es L. Agrégé d'Histoire et de Géographie

Translated by JOSEPH M C A BE

T. FISHER UNWIN LTD LONDON: ADELPHI TERRACE 
1.2815

. D392

First published in English in 1922

(All rights rescrved) 
13228

Bancroft Library

University of Californio

WITHURAWN

\section{INTRODUCTION}

In the following chapters I have endeavoured to indicate the essential aspects of colonization in modern Argentina: the conquest of the soil by man, the exploitation of its natural resources, the development of agriculture and cattle-breeding, and the growth of the population and enlargement of the urban centres.

For a new country like Argentina it is not convenient to adopt the strictly regional plan which seems to be the best means of giving a complete and methodical description of the historic countries of western Europe, where it is the only way to keep in close touch with the geographical facts. In western Europe each region is really an independent unity. It has for ages lived upon its own resources; each population-group has its horizon definitely limited; and the complex action of the environment upon man, and of man upon the country, has proceeded in each district rather on the lines of an isolated and impassioned dialogue between the two. It is quite different in Argentina. There, many of the facts which we have to record consist in an expansion of the population, a spread of methods of exploitation from zone to zone of the country, and the influence upon colonization of commerce and of the varying needs of the markets of the world.

It may be well to reply in advance to a criticism which my Argentine friends are sure to make. They will complain that I have paid no attention to the 
people of Argentina, the creators of the greatness of the country. It is true that I have deliberately refrained from any reference to the political and moral life of the Republic, the national character and its evolution, the stoicism of the gaucho, the industry of the colonist and the merchant, or the patriotism of the Argentinians generally. My work is not a study of the Argentine nation, but a geographical introduction to such a study.

I began the work during a stay in Argentina which lasted from April I9I2 to August I9r4. In the course of these two years I was able to visit most parts of the country; and, as the information I gathered during my travels is one of my chief sources, I give here a summary of my itineraries.

October-November I912: Rosario-Region of the colonies of Santa Fé-Forestry-industries of the Chaco SantiagueñoBañados of the Rio Dulce-Salta-Jujuy-Sierra de la Lumbrera.

November-December 1912: Tucumán-Valley of Tapi-Santa Maria to the west of Aconcagua-Cafayate (Valley of Calchaqui).

December 1912-January 1913: Catamarca-Andalgala-Valley of Pucara-Córdoba-Villa Maria.

January-February 1913: Region of the Pampas (Province of Buenos Aires, south of Cordoba and of S. Luis, district of the Central Pampa).

March I9I3: Corrientes-Posadas-Asunción-Forest-industries of the Chaco of Santa Fé.

August 1913: Region of the Pampas (Province of Buenos Aires).

March I9I4: Lake Nahuel Huapi-Valcheta-San AntonioThe Rio Negro.

April r9r 4 : Rioja-Sierra de los Llanos-San Juan-Mendoza. July r9I4； Entre Rios.

These journeys, by rail or on well-known roads, were not supposed to be for the purpose of exploration 
or discovery. Their one object was to enable me to make a provisional classification of the chief types of country and forms of colonization, and to draw up a methodical programme for more thorough research. The work which I trusted to do in a more leisurely way was, however, suspended in IgI4, and, in spite of my very strong desire to do so, I was unable to resume it on the spot in I9rg. I have therefore been compelled to publish my first observations, completing them, as well as I could, by a bibliographical study of the country. I have made use of some fragments of a popular work which I began, at the request of the Argentine Commission, for the International Exhibition at San Francisco, of which several chapters were published in my absence by the University of Tucumán (Pierre Denis, Modern Argentina: Chapters of Economic Geography. Publications of the University during the Centenary of the Congress of Tucumán of I8I6. Buenos Aires, I9I6). ${ }^{x}$

My knowledge of the publications on Argentina has two conspicuous gaps. The first is deliberate. I declined to study at second hand the documents and chronicles which are our sources, to the end of the eighteenth century, for the history of the various provinces that were to form Argentina. Hence the historical data on colonization which will be found in the following chapters relate almost entirely to the nineteenth century.

The second gap I was, to my great disappointment, unable to fill up. A large part of the local publications -official or other-maps, statistics, etc., never reached Europe, and Buenos Aires is the only place where one can make a thorough study of them. These publications were available to me until IgI4. Since then

I I take the opportunity to thank M. J. B. Teran, who undertook to edit these chapters, and to express, with him, my satisfaction that events have falsified his rather pessimistic predictions as regards the author. 
I have been restricted to the resources of the Paris and London libraries, which are very scanty; and less has been sent from Argentina since the war. I have not the complete statistics up to date.

I trust, however, that this picture of Argentina has much more than a retrospective character; that it is not out of date before it is published. I may add that no statistics would enable one to solve the problem which Argentina in 1920 presents to an observer. Has the European War merely retarded the economic evolution of the country, or has it given that evolution a new direction? Will or will not the relations which Argentina is now resuming with the rest of the world be of the same character as the pre-war relations?

The effects of the war upon the life of the country must not all be put on the same footing. That some of the exporters to Argentina have gained by the war and others lost-that the share of the United States, and even of Japan, has greatly increased-is a fact that may be regarded from the Argentinian point of view as of secondary importance. The war has, moreover, had the effect of disorganizing marine transport and bringing about a sort of relative isolation which is not yet quite over. The reduction in the imports of English coal has made the petroleum wells of Rivadavia of greater value to the country. It has compelled the Argentinians to make a hurried inventory of their natural resources in the way of fuel. Local industries have tried to meet the needs of the Argentinian market, where they had no longer to bear the competition of European goods. The grave disturbance of prices has enabled them to export certain products which had hitherto been confined to home markets. The war has, moreover, not interfered with the existing streams of export on a large scale from Argentina. The Republic continues to send its cereals, meat, hides and wool to Europe; and there is no reason to suppose that 
the competition of buyers is likely to diminish, or that the cultivation of wheat and lucerne must become less profitable.

The two essential effects of the war seem to have been the stopping of the stream of immigration and the progressive reduction of the support which Europe gave to the work of colonization in the form of advances of capital.

From I9I4 to I9I8 only 272,000 immigrants landed at Buenos Aires, while 482,000 emigrants left the country. In IgI 8 the figure of immigration and emigration was only 47,000 , less than a tenth of what it was in a normal year before the war. The withdrawal of European capital was felt from the very beginning of the war, and it has gone on uninterruptedly, capital from North America not being enough to supply the deficiency entirely. At the same time the extraordinarily favourable balance of trade has led to the storing of an ample reserve of capital in the country. Argentina has, in a very short time, won a financial independence which, in normal conditions, would have entailed long years of work and prosperity.

However it may seem, these two facts-the interruption of immigration and the accumulation of capital - cannot be considered independently of each other. The inquiry opened by the Social Museum of Argentina (La immigración despues de la guerra, Museo Social Argentino, "Bol. Mensual," viii, I9I9, nos. 85-90) show that a speedy restoration of immigration is expected in the Republic. Certainly it seems clear that the political and social insecurity in Europe, the misery of the old world, will probably enhance the attractions of Argentina. We must remember, however, that the stream of emigration from Europe to the Republic in the nineteenth, and the beginning of the twentieth, century was provoked by a complex combination of economic conditions which were closely related to each other. High wages in Argentina were connected with 


\section{0}

\section{INTRODUCTION}

the high interest on money; that is to say, in other words, with the scarcity of capital. The future will decide whether immigration, and the rapid progress of colonization and production, which characterize pre-war Argentina can be adjusted to the policy of accumulation of capital to which the war has condemned the country. 


\section{CONTENTS}

INTRODUCTION

PAGE

CHAPTER I

THE NATURAL REGIONS OF ARGENTINA

I7

The physical environment-Colonization and the natural regions-The struggle with the Indians-Argentine unityArgentina and the world.

\section{CHAPTER II}

THE OASES OF THE NORTH-WEST

The inhabited zones of the Andes in the north-westValles, Quebradas, Puna-The irrigation of the vallesThe historic routes-Convoys of stock-The breeding of mules and the fairs-The struggle of the breeders against drought-The Sierra de los Llanos.

\section{CHAPTER III}

TUCUMÁN AND MENDOZA

Tucuman and the road to Chile-The climate and the cultivation of the sugar-cane-The problem of manual labourIrrigation at Mendoza-Water-rights-Viticulture-Protection and the natural conditions.

\section{CHAPTER IV}

\section{THE EXPLOITATION OF THE FORESTS}

Manual labour on the obrajes-The land of the bañados and the agricultural cantons of Corrientes-The timber-yards of the Chaco and the tannic-acid works of the ParanaThe exploitation of the mate-The forestry industry and colonization. 


\section{CHAPTER V}

PATAGONIA AND SHEEP-REARING

The arid tableland and the region of glacial lakes-The first settlements on the Patagonian coast and the indigenous population-Extensive breeding-The use of pasture on the lands of the Rio Negro-Transhumation.

\section{CHAPTER VI}

\section{THE PLAIN OF THE PAMPAS}

The limits of the prairie-The rains-The wind and the formation of the clay of the Pampas-The wind and the contour-The zones of colonization on the Pampas-Hunting wild cattle and primitive breeding-The sheep-farmsThe ranches-The region of "colonies"-The region of lucerne, maize, and wheat-The combination of agriculture and breeding-The economic mechanism of colonizationThe exchanges between the different zones of the Pampas.

\section{CHAPTER VII}

ROADS AND RAILWAYS .

Roads on the plain-The salt road-The " trade route" Transport by ox-waggons-Arrieros and Troperos-Railways and colonization-The trade in cereals-Home traffic and the reorganization of the system.

\section{CHAPTER VIII}

\section{THE RIVER-ROUTES}

The use of the river before steam navigation-FloodsThe river plain-The bed of the Parará and its changesThe estuary and its shoals-Maritime navigation-The boats on the Paraná.

\section{CHAPTER IX}

THE POPULATION • • • . . . . . 260

The distribution of the population-The streams of emigration to the interior-Seasonal migrations-The historic towns-The towns of the Pampean region-Buenos Aires.

\section{BIBLIOGRAPHY}




\section{ILLUSTRATIONS}

PLATE

I. THE FALLS OF THE YGUASSU - . . Frontispiece

II. THE ARID ANDES-

FACING PAGR

PUNTA VACAS, ON THE TRANS-ANDEAN

RAILWAY • • . , . . , . 22

QUEBRADA DE IRUYA . . , , , , 22

III. THE PATAGONIAN ANDES . . . . . 38

IV. VEGETATION OF THE INTERIOR VALLEYS (ANDES

OF THE NORTH-WEST) . . . . . . 48

FOREST ON THE OUTER SLOPE OF THE SUB-ANDEAN

CHAINS • . . . . . . . 48

V. DRY SCRUB OF THE CENTRAL CHACO • . . 58

MARSHES (ESTEROS OR CANADAS) OF THE EAST-

ERN CHACO . . . . . . . $\quad$. 58

VI. THE VALLE OF SANTA MARIA, NORTH-WEST OF

MOUNT ACONCAGUA . • . • • 70

THE OASIS OF ANDALGALA . . . 70

VII. THE OASIS DEL RINCON, BELOW SAUJIL (ANDAL-

GALA LINE, PROVINCE OF CATAMARCA) • 82 THE MONTE AT EL YESO $\quad$. $\quad . \quad$. 82

VIII. A VINEYARD AT SAN JUAN • • • • • 92

A VINEYARD AT MENDOZA • • • • • : 92

IX. THE LAND OF THE BAÑADOS • • • . IOO

LORETO : FARMING BY INUNDATION • • • IOO 
X. LORETO: THE RIO PINTO IN THE DRY SEASON . II2 LA BANDA (SANTIAGO DEL ESTERO) • • • II2 XI. QUEBRACHO TRUNKS LYING AT THE STATIONS - II6 XII. YOKE OF CREOLE OXEN USED FOR THE TRANSPORT OF TIMBER ON THE EASTERN CHACO, OR CHACO OF SANTE FÉ • • • • • • I28 WORKS AT TARTAGAL (EASTERN CHACO) FOR MAKING TANNIC ACID . . • . • • I28 XIII. THE VOLCANO PUNTIAGUDO . • . . . I42 CERCAS ON THE LIMAY (RISING IN LAKE NAHUEL HUAPI), NEAR THE CONFLUENCE OF THE TRAFUL • • • • • • . . • I42 XIV. THE PATAGONIAN TABLELAND (NEUQUEN) • • I54 XV. THE PAMPEAN PLAIN-

TRES ARROYES (BUENOS AIRES PRAIRIE BETWEEN THE SIERRA DE TANDIL AND THE SIERRA DE LA VENTANA) • . . • I66 TOAY, ON THE CENTRAL PAMPA (590 FEET) • I66

XVI. THE PAMPEAN PLAIN-

THE RIO BAMBA (IN THE SOUTH OF THE CÓRDOBA PROVINCE, 500 FEET ABOVE SEA-LEVEL) • • • • • • • I82

BUENA ESPERANZA (SAN LUIS PROVINCE, I,I66 FEET ELEVATION) • • • • • • • I82

XVII. THE PAMPEAN PLAIN-

BUENA ESPERANZA (SAN LUIS PROVINCE) • $I 94$ JUNIN (I5O MILES WEST OF BUENOS AIRES, 330 FEET ELEVATION) • • : ; \& I94 
XVIII. AN OX WAGON . . . . . . . . 2 . 2

THE MAIL COACH . . . . . . . 210

XIX. THRESHING ON THE PAMPA . . . . . 220

SACKS OF WHEAT READY FOR LOADING ON THE

RAILWAY • . . . . . . . 220

XX. CONFLUENCE OF THE YGUASSU AND THE PARANÁ 236

XXI, THE PARANÁ AT CORRIENTES . • . . 244

THE BARRANCA AT PARANÁ (ENTRE RIOS), LEFT

BANK • • . . . . . . 244

XXII. THE PARANÁ ABOVE THE ESTUARY • • 250

XXIII. THE OLDER INDUSTRIES OF THE PAMPA-

DRYING HIDES • • . . . . 262

DRYING SALT MEAT • • • • • . 262

XXIV. A HERD OF CREOLE CATTLE . . . 268

A HERD OF DURHAM CATTLE. . . . . 268

\section{MAPS}

I. ARGENTINA : THE NATURAL REGIONS • • . 28

II. IRRIGATION IN THE WEST AND NORTH-WEST OF

ARGENTINA • . $\quad$. $\quad$. $\quad 52$

III. THE CATTLE-BREEDING AREAS • • • • I88

IV. DENSITY OF THE MAIZE CROP • • • • I $~ I 8$

V. DENSITY OF THE WHEAT CROP • • • . 200

VI. THE RAILWAYS • • . . • . . 226

VII. ESTUAARY OF THE RIO DE LA PLATA • • • 254 



\title{
The Argentine Republic
}

\author{
CHAPTER I
}

\section{THE NATURAL REGIONS OF ARGENTINA}

The physical environment-Colonization and the natural regionsThe struggle with the Indians-Argentine unity-Argentina and the world.

THE South-American continent is divided, from west to east, into three great zones. The lofty chains of the Andes stretch along the Pacific coast; at the foot of these are immense alluvial tablelands; further east are the level plains of the Atlantic coast. The eastern zone, the tablelands, ends southward at the mouth of the Rio de la Plata. It enters Argentine territory only in the north-east corner of the province of Misiones. Below $35^{\circ} \mathrm{S}$. lat. the alluvial plains open freely upon the ocean. The position of Buenos Aires, in the threshold of the plain of the Pampas, is somewhat like that of Chicago at the beginning of the prairies; if you imagine the north-eastern States and eastern Canada struck off the map, and the sea penetrating inland as far as the Lakes.

The three essential aspects of Argentine scenery are mountain, plain, and river. The Paraná, indeed, is a whole natural region in itself, with its arms and its islands, and the ever-changing low plain over which its floods spread, as one sees it from the top of the clay barrancas (cliffs); though it is so broad that one cannot see the opposite bank. It wanders over the plain like 
a foreigner, an emissary from tropical America; for it has a flora of its own and tepid waters which often cause a fog over the estuary where they mingle with the waters of the sea.

From the general mass of the Argentine plains, we must set apart the region between the Paraná and the Uruguay, which Argentinians call "Mesopotamia." While æolian clays form the soil of the Pampa on the right bank of the Paraná, fluvial deposits-sands and gravel, in which it is impossible to distinguish the contribution of the Uruguay from that of the Paranácover a great part of Mesopotamia. The earlier beds of the rivers may be traced here, not only by the alluvial deposits they have left, but by the lagoons which still mark their course. Running waters have shaped the landscape and scooped out a system of secondary valleys, and these reflect the history of the river itself and the variations of base-level which led to alternate periods of erosion and deposit.

On the right bank, on the contrary, the Paraná has no tributaries of any importance except at the extreme north of the country. The scarcity of running water is, in fact, one of the characteristic features of the plain of the Pampas. Except in the east, along the Paraná, where a network of permanent streams develops on a comparatively impermeable and fairly humid soil, and except at the foot of the mountains, where irregular torrents and streams, swollen after a storm and scanty in the dry season, disappear, as a rule, within sight of the hills that gave them birth, there is no superficial organized drainage. As a whole, the alluvial covering of the Pampas, the upper beds of which are cut through by the barranca of the Paraná, is not of river origin; it was brought and distributed by the wind, which took the place of running water. The clay of the Pampas is a present from the winds. The increasing dryness of the climate toward the west, as one approaches the Cordillera, 
explains the feebleness of the erosion by water and the extent of the erosion by wind.

It is aridity, too, that gives their particular character to the Argentine Andes. They have little trace of perpetual snow, the lower limit of which approaches to within about four miles of the Bolivian frontier. There are no glaciers there; they reappear in the south only in the latitude of San Juan and Mendoza, on the flanks of the three giants of the southern Cordillera, Mercedario, Aconcagua, and Tupungato. Below the small number of steep furrows which the glaciers have carved, and usually up to the top of the mountain, there spreads what has been called, very expressively, " the zone of rubbish." In this the winter's snows, fretted by the sun in that clear atmosphere, form those multitudes of narrow pyramids which the Argentinians compare to processions of white-robed pilgrims. The underlying rock is rarely visible. It is covered with a thick cloak of rubbish, split off by the frost, which the slow-moving waters released by the melting of the snows heap up at the foot of the slopes, at the bottom of depressions. The half-buried summits are succeeded by basins of accumulation. In the valleys round the mountains there are immense beds of detritic, halfrounded shingle. The torrents have cut their way through the alluvial mass, and they flow at the foot of high terraces which mark the sites of former valleys.

The spread of colonization toward the south during the last generation has extended Argentine territory beyond the limits of these classic scenes. The Patagonian Andes differ profoundly from the Northern Andes; and the change is not more sudden than that of the climate, to which it is due. Going toward the south, one passes, almost without a break, from the Atlas Mountains to Scandinavia. The moisture increases in proportion as the mean temperature falls. The mountains are covered with snow, and the glaciers 


\section{NATURAL REGIONS OF ARGENTINA}

lengthen. In one part of Patagonia they still form a continuous cap, an "inland sea," concealing the rock over the entire central zone of the Cordillera; though they are only the shrunken remainder of a glacial cap which was once far more extensive. Here ice was the chief sculptor of the scenery. It has made elevated tablelands, broadened the deep valleys which cut the flank of the mountain, polished their sides, and deposited at the point where they open out the amphitheatres of the moraines, behind which the waters have accumulated and formed lakes; and these lakes stretch back like fiords to the heart of the Cordillera, and are the pride of Patagonia.

The waters of these moisture-laden mountains have, to the east, carved out the Patagonian tableland. It is crossed by broad and boldly cut valleys, several of which, abandoned by the rivers which scoured them, are now dead valleys. The rubbish from the wearing down of the mountains and the glacial moraine has been spread over the whole face of the tableland in the form of beds of gravel. But the rivers that rise in the Andes cross a country of increasing aridity as they descend eastward. There is no tributary to add to their volume. There is none of that softening of lines, of that idle flow of a meandering stream which characterizes the final stage of a river in a moist district. Their inclination remains steep, and their waters continue to plough up coarse sediment; and everywhere, up to the fringes of the valleys, the fluting of the sandstone and steepness of the cliffs bear witness, like the edges of the hamadas of the Sahara, to some other form of erosion than that effected by running water-the influence on the country of the westerly winds. On the tableland the wind polishes the rounded pebbles, makes facets on them, and gives them the colouring of the desert.

Thus from the north to the south of Argentina there is a complete contrast in the way in which the 


\section{MAN AND THE SOIL}

controlling forces of the landscape are distributed. In the north the moist winds come from the east; the rains lessen as they pass westward. The clays, capped with black soil, of Buenos Aires are æolian deposits, brought by the wind from the desolate steppes which close the Pampa to the west, fixed and transformed by the vegetation of a moister region. In the south, on the contrary, the rains come from the Pacific, and the fluvio-glacial alluvial beds of the Patagonian tableland are evidence of copious reserves of moisture in the Andes; but the arid climate in which the waters have left them has made its mark upon their surface.

This diversity of the physical environment is only fully brought out by colonization. It is colonization, the efforts and attempts of human industry to adjust agricultural or pastoral practices to the natural conditions, which enable us to assign the limits of the natural regions. In this differentiation it is essential to notice the historical element.

The introduction of new crops gives a geographical meaning, which had hitherto escaped observation, to climatological limits such, for instance, as the line of 400 millimetres of rainfall which is the western frontier of the region of cereals. These limits of crops remain uncertain for a time, then experience and tradition gradually fix them. They always keep a certain elasticity, however, advancing or receding according as the market for the particular produce is favourable or unfavourable.

Improvement in the methods of exploiting the soilthe adoption of better agricultural machinery, dry farming, etc.-usually leads to the extension of the sphere of a particular type of colonization, as it enables this type to overcome some natural obstacle which restricted its expansion. Sometimes, however, it brings to light a new obstacle and creates a new geographical limit.

To this category belongs the northern limit of the 


\section{NATURAL REGIONS OF ARGENTINA}

belt of selective breeding, which slants across the plain of the Pampas from the Sierra de Córdoba to the Paraná. The more or less degenerate cattle of the natives had spread over the whole of the South American continent, except the tropical forests, since the seventeenth century, adapting themselves easily to very different climatic conditions, from the Venezuelan llanos to the sertao of Bahia and the plains of Argentina. But pedigree animals, more valuable and more delicate, introduced on to the Pampas fifty years ago, are not able to resist the malady caused by a parasite called the garrapate. Hence the southern limit of the garrapate suddenly became a most important element in the economic life of the Republic. It would lose its importance if we discovered a serum that would give the animals immunity against Texas fever.

The range of one and the same cause varies infinitely with the circumstances. The limit of the prairie, as of the scrub (monte) which surrounds it on every side, and keeps it at a distance of 320 to 440 miles from Buenos Aires, had no decisive influence on primitive colonization. Whether covered with grasses or brushwood, the plain is equally suitable for extensive breeding. The ranches are the same on both sides of the border. At the end of the nineteenth century, however, when the area of cultivation increased, the prairie was at once found to be superior. The labour required for clearing the brushwood before the plough can work is enough to divert from it, at least for some time, the stream of agricultural colonization. While the population of the monte, wood-cutters and breeders, are indigenous, the prairie has absorbed the immigrants from Europe, and the border of the scrub has become in many places an ethnographical frontier. ${ }^{\mathbf{r}}$

The changes which man has made in the floral land-

I See E. A. S. Delachaux, "Las regiones fisicas de la Republica Argentina," Rev. Museo Plata, xv, I908, pp. I02-131. 


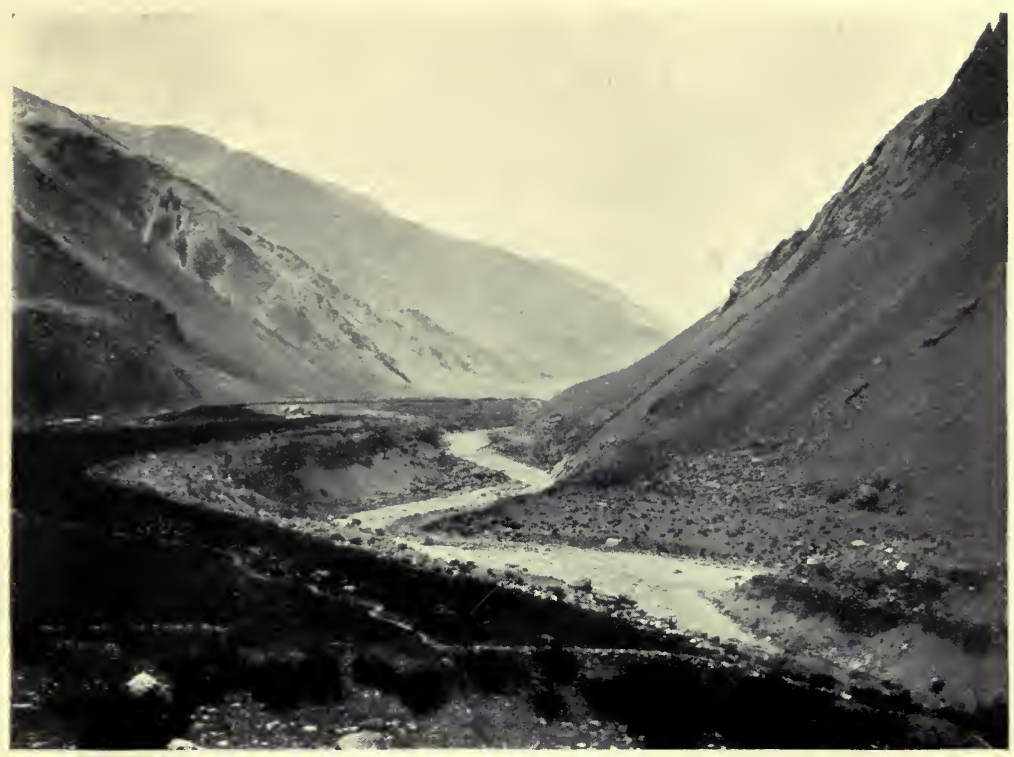

THE ARID ANDES. PUNTA VACAS, ON THE TRANS-ANDEAN RAILWAY.

The bottom of the valley is 8,000 feet above sea-level ; the sides buried under rubbish. It is especially in this latitude, above a height of 10,600 feet, in the zone where the moisture falls as snow even in summer, that the rock is everywhere buried under its own rubbish. This is Keidel's Schuttzone. It extends to the foot of the Alpine peaks, carved by glaciers.

Photograph by Moody, Buenos Aires.

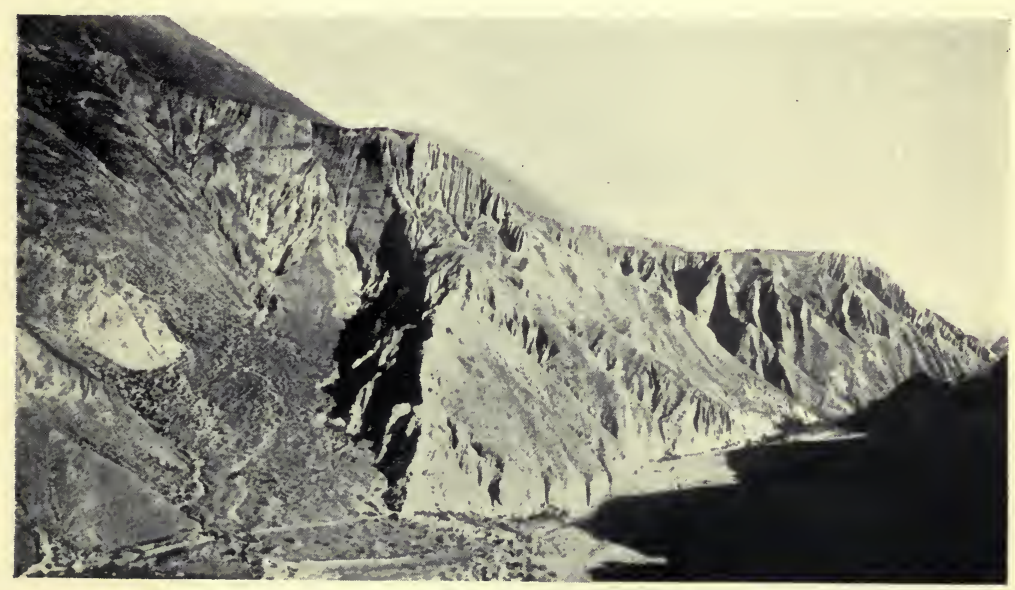

QUEBRADA DE IRUYA.

Eastern slope of the Sierra de Santa Victoria, 65 miles from the Bolivian frontier, in the zone of summer rain. The valleys have been filled with an enormous mass of torrential alluvia. The water afterwards made a course through the mobile deposits.

Photograph by Keidel, Mines Division. 

scape are, as a rule, slight. The limits of the forest zone have scarcely been altered. The beech forest of the southern Andes seems to be less tenacious than the monte which surrounds the Pampa, and it has been ravaged by fire along the whole edge of the southern steppe at $37^{\circ} \mathrm{S}$. lat. The work of man is generally confined to changing the primitive complexion of the natural formations, without altering their general appearance. Thus valuable essences are disappearing from the forest and the scrub, the larch and the cypress from the district of the Patagonian Lakes, and the red quebracho from Santiago del Estero.

A change that is scarcely visible, but is of considerable economic importance, thus takes place in the vegetation of the prairie owing to the presence of herds. The pasto fuerte, composed of rough grasses, which is the natural vegetation, is being succeeded by the pasto dulce, in which annual species, soft grasses, leguminous plants, etc., predominate. It is mainly composed of plants of European origin. The difference between the pasto dulce and the pasto fuerte or duro is so important for the farmer that there is hardly a single work on Argentina which does not dwell on it. The idea, however, that the pasto dulce has advanced steadily westward, starting from the vicinity of Buenos Aires and constantly enlarging its domain, is not strictly accurate. In I895 Holmberg I traced the western limit of the zone of the pasto dulce through Pergamino, Junin, Bragado, Azul, Ayacucho, and Mar Chiquita. When we compare this with earlier observations, we see that in the course of the nineteenth century the zone of the pasto dulce has extended by about a hundred miles on the southern Pampa. When Darwin travelled from Bahía Blanca to Buenos Aires in I833, he found no pasto dulce except round Monte, on the right bank of the Salado. Further north, on the other

I Holmberg, "La Flora de la Republica Argentina," in the Secundo Censo de la Republica Avgentina, vol. i. (Buenos Aires, 1898). 


\section{NATURAL REGIONS OF ARGENTINA}

hand, the extent of the pasto dulce does not seem to have altered appreciably. The expedition to the Salt Lakes in 1778 found that there were already thistles beyond the line of the ranches, and these are characteristic of the pasto dulce in the Chivilcoy region on the Salado, which was then abandoned to herds of wild cattle. "There was thistle enough to cook," says the journal of the expedition. The difference is connected with the history of colonization in the province of Buenos Aires, where ground was gained only toward the south between 1800 and 1875 . Since 1895 the pasto duro has been eliminated by agriculture rather than by the feet of the herds. Hence the advance of the pasto dulce is no longer in a continuous line moving toward the west. It is sporadic, depending upon the construction of new railways which open up the plain to the plough. ${ }^{x}$

Colonization does more than emphasize the individuality of each of the natural regions. It connects together different features, and blends them in a complex vital organism which goes on evolving and renewing itself.

The occupation of the whole of the soil of Argentina by white colonists is quite a recent event. The second half of the nineteenth century was characterized by a rapid territorial expansion, and over more than half the country the expression " new land " must be taken literally. It is only one generation since it was taken from the Indians. There can be no question here of tracing the history of the relations between the white population and the free Indians of the Chaco and the Pampa. The most formidable of these were, in the north, the Abipones and the Tobas. On the Pampa, the foes of the colonists were Indians of Araucanian descent, Ranqueles, Pehuenches, etc., who came down from the mountains and took to horses. At the close of the eighteenth century the frontier

- Diario de la expedicion de 1778 a las Salinas (Coll. de Angelis, iv.). 
of Buenos Aires was on the nearer side of the Salado, and was bordered on the south-east and north-west by the fortresses of Chascomus, Monte, Lobos, Navarro, Areco, Salto, Rojas, and Melincue. The proposal of D'Azara to extend it as far as the Salado was not carried out, and it was not until 1828 that there was a fresh advance westward. ${ }^{x}$

The new frontier, which would not be altered until I875, passed by Veinte Cinco de Mayo and Blanca Grande, at the north-western extremity of the Sierra de Tandil. It included the entire region which lies between the Sierra de Tandil and the lower Salado, where the village of Tandil had been established in r823. In addition, a line of forts stretched from Blanca Grande in the south-west to Bahía Blanca. The expedition sent in search of a port south of the mouth of the Plata had not found any nearer site that was suitable. But Bahía Blanca was to remain an isolated advance post until I880, sharply separated from both the colonized zone of the Pampas and the establishments on the Patagonian coast.

While the cultivated area was thus growing toward the south, it was being reduced in the north of the province of Buenos Aires and the south of Córdoba. The lands of the lower Rio Cuarto were not occupied. About I860 (Martin de Moussy) the farthest establishments in this sector were S. Jose de la Esquina and Saladillo on the Tercero. The road to Chile by the Rio Cuarto, Achiras, and San Luis was threatened. The advance of colonization in this zone was at first in the west to Villa Mercedes on the Rio Quinto. The

- F. de Azara, Diario de un reconocimiento de las guardias y fortines que guarnecen la linea frontera de Republica Argentina (1796, Coll. de Angelis, vol. vi.). The documents collected by de Angelis show clearly that there had been some idea in the middle of the eighteenth century of occupying the whole plain to the east of the Sierra de Tandil. These ideas of expansion, of which D'Azara's plan is another instance, were interrupted by the Revolution (Diario de D. Pedro Pablo Pabon, Coll. de Angelis, iv, etc.). 


\section{NATURAL REGIONS OF ARGENTINA}

line of the Rio Cuarto by Carlota was reoccupied, and before 1875 the frontier had been pushed back to the Rio Quinto, where it joined the forts of southern Buenos Aires by way of Sarmiento, Gainza, and Lavalle.

At last, in 1878 , General Roca abandoned the classical methods of fighting the Indians, and took the offensive. $\mathrm{He}$ deprived the Indians of their refuges to the south of San Luis and the Central Pampa, and threw them back toward the desert. The Argentine troops followed in their steps as far as the Andes and the Rio Negro. There are to-day few traces in the immense territory that was won of the indigenous population. Its extreme mobility had masked its numerical inferiority. ${ }^{\mathrm{I}}$

The history of the northern frontier is much the same. At the end of the eighteenth century the Spanish outposts ran along the course of the Salado. To the north of Santa Fé, at Sunchales, Soledad, and San Javier, they protected the direct route from Santa Fé to Santiago del Estero. These outposts were abandoned during the revolutionary period, and the Indians advanced as far as the suburbs of Santa Fé. The roads both to Santiago and, by the Quebracho Herrado, to Córdoba were cut. ${ }^{2}$ Urquiza reorganized the Santa Fé frontier, first as far as San Javier, then below $29^{\circ} \mathrm{S}$. lat. between Arroyo del Rey on the Paraná and Tostado on the Salado. The expedition of 1884 brought the Argentine army as far as the Bermejo, and broke the resistance of the Tobas. The forts which, more to the north, guarded the province of Salta,

I M. J. Olascoaga gives (La conquête de la Pampa Receuil de documents relatifs d la campagne du Rio Negro, Buenos Aires, I88I) valuable documents concerning both the details of the fight with the Indians and the distribution of their invernadas (common lands) in the region of the Pampas. Olascoaga translates it " winter quarters" ; it was pasturage on which they kept their cattle and from which they set out on their expeditions.

- See Thomas J. Hutchinson, Buenos Aires and Argentine Gleanings. 


\section{FIGHTS WITH THE INDIANS}

on the further side of the Sierras de la Lumbrera and Santa Barbara, had been dismantled at the beginning of the nineteenth century, as the tribes in this part of the Chaco were not hostile. ${ }^{\mathrm{I}}$

The memory of the fights with the Indians is so completely blotted out to-day, and the menace of invasion by the tribes has been so rapidly extinguished, that it is difficult to realize fully the profound influence they once had on colonization. The line of forts was a frail barrier that was constantly broken through. The Indians of the Pampa stole cattle from the ranches of Buenos Aires, and sold them in Chile. Colonel Garcia calculates in I8I6 that about 40,000 animals were stolen every year. ${ }^{2}$ Colonel Roca gives the same figure in 1876. The Pampa put no natural difficulties in the way of the movements of the Indians, no points which might serve as bases for the frontier. D. Pedro Pablo Pabon points out that the proximity of the Sierra, instead of giving protection to outposts in the Tandil region, would be an additional source of insecurity, as it increased the difficulty of keeping watch. In the north the Indian incursions followed the clearings in the scrub, avoiding the dense and impenetrable parts. The lagoon of Mar Chiquita, to the west of Santa Fé, was a valuable rampart, in the shelter of which a fairly large population had established itself round Concepción del Tio.

The enlargements of the frontier were sometimes due to expansive movements of colonization, the breeders occupying new land beyond the line of forts and demanding protection, and sometimes to the arbitrary action of a Government which was eager to extend its territory, though it was still without the means of exploiting it. Roca has well shown the

"See Geronimo de la Serna, "Expedicion militar al Chaco," Bol. I, Geog. Argentino, xv. 1894, pp. II 5-79.

:Nuevo plan de fronteras de la provincia do la Republica Argentina (Coll. de Angelis, vol. vi). 


\section{NATURAL REGIONS OF ARGENTINA}

defects of this system of premature military occupation. "To go far away from the populated districts in acquiring new territory is, in my opinion, only an aggravation of the inconveniences of defensive war, and it places a desert between the new lines and the settled regions. ... Invasions occur at once."' We should therefore be likely to make serious mistakes if we were to identify the history of colonization with that of military occupation. Moreover, the garrisons of the forts did not take a very active part in the exploitation of the soil. The plan which D'Azara proposed, of making blandengues (lancers) colonists and rooting them to the soil by distributing it amongst them, seems to have been purely Utopian. His description of the frontier shows clearly how slight a hold the early colonization had on the Pampa, where the only relatively industrious element was represented by the groups of civilians (paisanos) who gathered about the works and moats of the forts. It was different on the Santiago del Estero frontier, where there was agriculture as well as breeding. Here the fort was identical with the village, and each soldier had his plot of wheat, maize, or water-melons. ${ }^{2}$

The provinces which were to combine in forming the Argentine Republic had no economic unity. They were really two countries, two separate worlds, the coast regions and the mountain regions (de arriba), joined together, but not blended, by the main road from Buenos Aires to Peru, by way of Córdoba, Tucumán, and Salta. They represented two different branches of Spanish colonization. "Two human streams," says Mitre, "contributed to the peopling of the vice-royalty. . . . The first came directly from Spain, the mother country. It occupied and peopled

Letter to the Minister of War, October 19, I875.

- See the curious picture, which Hutchinson gives us, of military life on the Rio Salado de Santiago about the middle of the nineteenth century. 


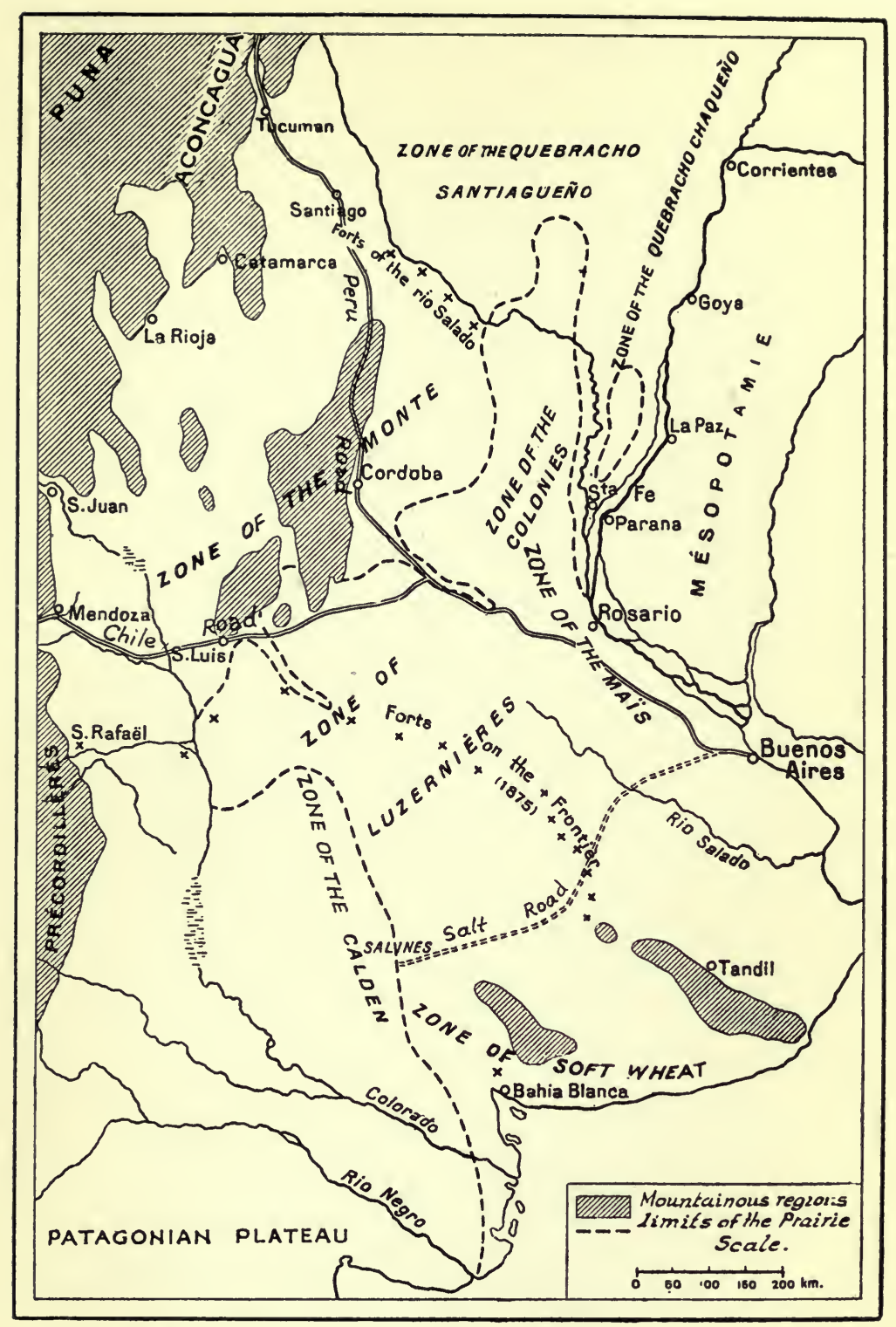

MAP I.-ARGENTINA. THE NATURAL REGIONS.

The map shows the distribution of the natural regions-the dry Andes in the north-west, with irrigated cultivation; the monte, or brush, which is still used for extensive breeding; and the Pampa, with its great areas of cereals and lucerne. The line marking the frontier of 1875 shows the speed at which colonization has developed in the western half of the plain of the Pampas. The only regions not given on the map are the plateau of Misiones, with its tropical forests, and the wet Andes of Patagonia. 

the banks in the basin of the Rio de la Plata, in the name of the right of discovery and conquest, and fertilized them by its labour. The other stream came from the ancient empire of the Incas, already subdued by the Spanish armies. This spread toward the interior of the country as it passed from the Pacific to the Atlantic, occupied the land in virtue of the same rights, and exploited it by means of a feudal system. . . . The same year, I535, saw the foundation of the two towns, Buenos Aires and Lima, and was the centre of these two cycles of discoveries and conquests. Thirty-eight years later, in the same year, I573, the Conquistadores who came from Peru founded the town of Córdoba, two hundred miles away from the Paraná, while those who came from the Rio de la Plata founded the town of Santa Fé on the banks of that river."I

Tucumán and Salta were established by conquerors from Peru, while San Juan and Mendoza were built by the Chilean Spaniards. The line of demarcation between the two zones of colonization crosses the immense desert plains of the interior, not the elevated tablelands of the Andes.

The two types of Argentinians differed in every respect, in blood as well as in environment. The indigenous race, which was eliminated on the coast, mingled intimately with the conquering race in the interior.

The establishments on the Rio de la Plata had originally been merely stages on the road to Peru, and had no value of themselves. The elevated tablelands of the Andes long remained the economic centre of Spanish America, and the provinces of the interior, which sold them cattle and mules, depended very closeiy upon them. The end of the eighteenth century was marked by more rapid progress in the region of the Pampas. The vice-royalty of La Plata was created. × Mitre, Historia de Belgrano, I, ch. i. pp. 4 and 5. 
Freedom of trade was secured between Buenos Aires and the Spanish ports. The export of hides increased. The influence of Buenos Aires spread over the interior and, in spite of the Córdoba tariff, reached the regions of the north-west. "The creation of the viceroyalty," says Dean Funes, "and the new direction taken by commerce had the effect that Buenos Aires became the centre of considerable and important business."1

This commercial development, which seemed destined to bring closer together the two halves of Argentinian territory, was interrupted in the first half of the nineteenth century. This did not, however, break the connections between the provinces to the north-west of the tableland and those on the Pacific slope, and indeed, they became more varied and more binding. Packs of mules, carrying the ore of San Juan and La Rioja to the foundries of the Chilean side, added life to the Cordillera. When Chile, transformed into an agricultural country, could not meet its own demand for cattle, the oases of the Argentine side were sown with lucerne for fattening the cattle which were to cross the mountains. The provinces of Mendoza, San Juan, La Rioja, Catamarca, Tucumán, and Salta were held within the orbit of the Andes districts.2 There are historical reasons for this set-back to the influence of Buenos Aires. The wars of the revolutionary period and the conflicts between the Buenos Aires Government and the maritime powers checked the commercial enterprise on the banks of the Plata. This political isolation of the province of Buenos Aires, under the Rosas Government, lasted until I853. Poncel gives us statistics of the imports of Catamarca

3 D. Gregorio Funes, Ensayo de la historia civil del Paraguay, Buenos Aires, y Tucumán (Buenos Aires, 3 vols., 18r6).

2 The Woodbine Parish map (1839) puts Tinogasta eighty miles out of its proper position, at the very foot of the Come Caballos range, thus reducing by one half its distance from Copiapo, on the Chilean slope. 


\section{THE GROWTH OF BUENOS AIRES}

which show the great importance of this date in the history of Argentine commerce:

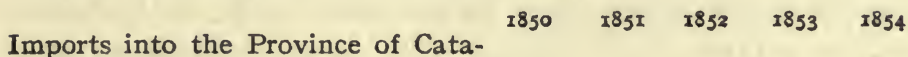
marca:

From the Pacific across the Cor$\begin{array}{llllll}\text { dillera (in millions of piastres) } & 72 & 50 & 71 & 40 & 12\end{array}$

From the Atlantic (Buenos Aires $\begin{array}{lllllllllll}\text { or Rosario) } & \ldots & \ldots & \ldots & \text { II } & 7 & 20 & 64 & \text { II }\end{array}$

In I854-5 the Cordillera route definitely ceased to be of commercial importance to Catamarca, and it was afterwards used merely for the export of cattle.

But the attraction of Buenos Aires after 1853 was not merely due to its commercial life and its intermediate position between the provinces of the interior and Europe. It was chiefly based upon the economic development of the region of the Pampas, which began about this date, and altered the balance between the two halves of Argentina. The exploitation of the Pampa, the improvement in breeding methods, and the introduction and expansion of agriculture on the plain of the Pampa, which fill all publications on modern Argentina, are in themselves one of the great events in the economic history of the nineteenth century. They had also an indirect but profound influence upon the life of other parts of Argentina. The consuming capacity of the Pampa increased simultaneously with its wealth and population. It absorbed the products of the neighbouring provinces and in turn made customers of them, distributing amongst them, according to the services they rendered, part of the gold it obtained from beyond the Atlantic. One after the other the provinces lost the relations which had hitherto connected them with foreign lands. There was the same development all over the zone of cereals and lucerne-the direction of the stream of commerce was reversed. In some places, as at

- B. Poncel, Mes itinéraires dans les Provinces du Rio de la Plata, Province de Catamarca (Paris, 1864). 
Tucumán and Mendoza the change was accomplished a generation ago. In other places, as at Salta and San Juan, it is still going on. In yet other places, the more remote valleys, like Jachal and Santa Maria, it will occur in the near future. By a singular anomaly the Far West of North America, which sprang up half a century ago, tends to withdraw more and more from the influence of the eastern States, which provided it with capital and immigrants, while the Far West of Argentina, which is just as old as the east and by no means a creation of the east, since it developed in isolation and freedom, and was already adult and rich when they came into contact, has nevertheless fallen into complete dependence upon the east in the course of a few years.

The life of the whole country depended upon the great colonization movement which transformed the plain of the Pampas. This brought about an economic unity which was at once reflected in the political world. The railway from Buenos Aires reached Tucumán before I880; Mendoza, San Juan, Salta, and Catamarca before I890; and La Rioja before I900. The establishment of closer economic relations between the coast and the provinces of the interior has nearly always inaugurated a period of great prosperity for the latter. In every case the influence of Buenos Aires vitalized them, put an end to their slumbers, and made them rich.

Not only did the coast take for itself the products of the western provinces, which had hitherto found their way to other markets, but new centres of production had to be created to meet its needs. The forests of the Chaco received a great influx of wood-cutters, to provide the sleepers for the railways. The valley of the Rio Negro was planted with vines, to provide the wines of the colonies in the district of Bahía Blanca. The attraction of the Pampa was felt as far as the frontiers. Paraguay competed with Corrientes in 


\section{MENDOZA AND TUCUMÁN}

the supply of tobacco and oranges; with Misiones in the supply of yerba maté. Each district chose the particular crop which was best suited to its climate, in order to secure the highest possible advantage from its relations with Buenos Aires.

The two most brilliant satellites of the Pampa, the most important productive centres of the interior, are Tucumán and Mendoza. All the other important towns of Argentina belong themselves to the region of the Pampas. Tucumán and Mendoza, which live by supplying the Pampa with sugar and wine, have become in turn secondary centres of attraction. They are a sort of regional capitals, and they have their own spheres of economic influence. A network of commercial streams has developed about them, and this has led to the formation of new roads. These lines of local interest are easily recognized on a map of the railways, where one sees them superimposed upon the regular fan of lines which converges toward Buenos Aires. La Rioja provides the props for the vines of San Juan and Mendoza. From the north of Córdoba to Salta, a distance of about 250 miles, the wood is cut for the fuel of the sugar-works of Tucumán. Santiago dries the fodder for its troops of mules. The prairies of Catamarca, which once fattened the cattle that were intended for Chile, and often came even from Tucumán, now sell their beasts to the butchers of Tucumán. The wines of San Juan find their best customers at Tucumán. Even the nearest portions of the plain of the Pampas, to the north-east of Santa Fé and the south of San Luis, supply maize and wheat to Tucumán and Mendoza, instead of sending them to the ports for export.

While Argentina lives on the Pampa, the Pampa lives on export. It has been developed through the inflow of European immigrants, and Europe pays by sending its manufactured products and capital. Except as regards emigration, the United States had, 


\section{NATURAL REGIONS OF ARGENTINA}

before the war, much the same relation to Argentina as the countries of Western Europe. Thus the economic prosperity of the Republic binds it more and more closely to the life of the whole world. Its position in the temperate zone of South America had retarded its entrance into world-commerce, and this explains the slowness with which its colonization proceeded at first. Its climate and products were too similar to those of Spain. Not only the mining and metallurgical centres of the Andes and of Mantiqueria, but even the sugar and cotton regions of Brazil, the Antilles, and the Guianas, were developed before the plains of the Pampas.

The turn of the Argentine Republic did not come until the growth of population in the industrial countries of Europe made them dependent upon foreign lands for their food, and until the application of steam to ships made it possible to export wool, meat, and cereals on a large scale.

When we compare the economic organization of Argentina with that of the United States, we see that it is both less complex and less capable of being selfcontained. The difference is due to the architecture of the country. I said at the beginning of this chapter that Argentina has no equivalent for the zone of the Atlantic tablelands, which is now the great industrial region of North America. The industrial prosperity of eastern North America provides a safe home market for the farmers of the west, and relieves them of the need of exporting their produce. Moreover, the Atlantic tablelands, the original centres of population, where the first generations of colonists lived on land that was often poor, have seen the gradual formation of reserves of labour and capital which were afterwards used in colonizing the west. The east sifted, in a sense controlled, the influence of modern Europe in the colonization of the United States. It classified and assimilated the new emigrants who set out for the west, 


\section{FOREIGN MARKETS}

mingled with the troops of native pioneers on their way to the prairies. In the same way, when European capital flowed into the United States, it found in the eastern cities a large treasury and a body of financiers in whose hands it had to remain.

In Argentina, on the contrary, everything speaks of the close and direct dependence of the country upon oversea markets. The soil itself bears the marks of this solidarity. It is seen in the network of the railways, the concentration of the urban population in the ports, and the distribution of the cultivated districts in concentric circles which are often limited, not by a physical obstacle, but by the cost of freightage between the productive centre and the port. Thus we get a geographical expression of facts which seem at first sight to belong to the purely economic or sociological order. 


\section{THE OASES OF THE NORTH-WEST AND PASTORAL LIFE IN THE SCRUB}

The inhabited zones of the Andes in the north-west-Valles, Quebradas, Puna-The irrigation of the valles-The historic routesConvoys of stock-The breeding of mules and the fairs-The struggle of the breeders against drought-The Sierra de los Llanos.

THE whole life and wealth of the arid provinces of north-western Argentina depend upon irrigation; the water-supply definitively settles the sites of human establishments. The water resources are irregularly distributed. They are especially abundant in the south (San Juan, Mendoza, and San Rafael), where the torrents of the Cordillera are fed by the glaciers, and on the outer fringe of the hills above the Chaco, at the foot of Aconcagua, which gathers masses of cloud and rain on its flanks (Tucumán). In the intermediate district, on the contrary, in the regions of La Rioja and Catamarca, and in the interior of the hilly zone to the north-west of Tucumán, the amount of available water is small ; the oases shrink into small spots far removed from each other.

This natural inequality was not felt at first. For a long time the spread of cultivation and the progress of wealth were restricted only by the scarcity of population, the difficulties of transport, and the inadequacy of the markets. The best endowed oases paid no attention to the surplus supply of water, for which they had no use. We have to come down to the close 


\section{THE ANDEAN VALIEYS}

of the nineteenth century to find men reaching the limits which nature has set to colonization, and mapping out their domain. It is not until then that La Rioja ceases to compete with Mendoza, or Catamarca with Tucumán. While large industrial enterprises develop at Mendoza and Tucumán, strong centres of urban life arise, the population increases, and immigrants stream in, the oases of the interior scarcely change. Their population does not keep its level. Life has an archaic character that one finds nowhere else in Argentina. The physical conditions have retarded, one would almost say crystallized, the economic development. The living generation exploits the soil in ways that to some extent go back as far as the indigenous tribes, the masters of their Spanish conquerors in the art of irrigation. The industry of fattening and convoying cattle, which was once the chief source of wealth of the whole country, is still alive in those districts.

The zone of the elevated tablelands of the Andes without drainage toward the sea-the Puna-has still, below $22^{\circ} \mathrm{S}$. latitude on the northern frontier of Argentina, a width of about 250 miles. This breadth steadily contracts southward as far as $28^{\circ} \mathrm{S}$. latitude, where the Puna ends about the level of the road from Tinogasta to Copiapo.

To the east and south of the Puna the Argentine Andes are cut from north to south by a series of long gullies and large basins, between which there are lofty and massive chains with steep flanks. Some of these lie in the heart of the mountains, while others often open like gulfs upon the edge of the plain. These depressions with rectilinear contours are a common feature of the topography of the Andes in this latitude. The central plain of Chile is closely related to them. In the Argentine speech they are called valles: Valle de Lerma, Valle Calchaqui, Valle de Iglesias, de Calingasta, d'Uspallata. They are, however, not "valleys" in 
the sense of hollows made by erosion by running water. They owe their formation to tectonic movements, subsidences of the surface.' The scanty rivers of the arid Anacs are not capable of doing work of that kind. When they enter the already formed bed of a valle, they seem to be lost in the immense space. Often they dry up in it, leaving behind the sediment and salts with which the water was laden. In other places they cut at right angles across the valle, escaping by narrow breaches in it, while the depression continues its course on either side, taking in sections of a number of independent streams.

Opposed to the valle is the eroded ravine, carved out by water, the quebrada. It opens upon a valle with a V-shaped mouth, which widens out at the top, and one can recognise at sight the various slopes and the successive stages of erosion. Narrow and winding, a level bed of shingle filling the entire base of the valley, it rises rapidly toward the mountains and provides a route from the valle to the puna. These valles, quebradas and puna are the three inhabited zones of the Andes. The first is the richest. The inhabitant of the valle, proud of his comparative comfort, has for his neighbour in the quebrada or the puna-the coyada-a contempt such as one finds the inhabitants of the good land in Europe feeling for the people in poorer districts.

The narrower the valle, the less rain there is. The observations give II2 millimetres of rain per year at Tinogasta, 290 at Andalgala, and 200 at Santa Maria. Salta and Jujuy have a much moister climate, and have no less than 570 and 740 millimetres of rain annually. This is because the eastern chain of the Andes, which stretches from the Sierra de Santa Victoria on the Bolivian frontier to Aconcagua, sinks lower at the latitude of Salta, and lets in the moisture of the Chaco to the heart of the zone of the Andes. The rains of Salta and Jujuy are suspended during the winter, but they are so heavy during the summer months 


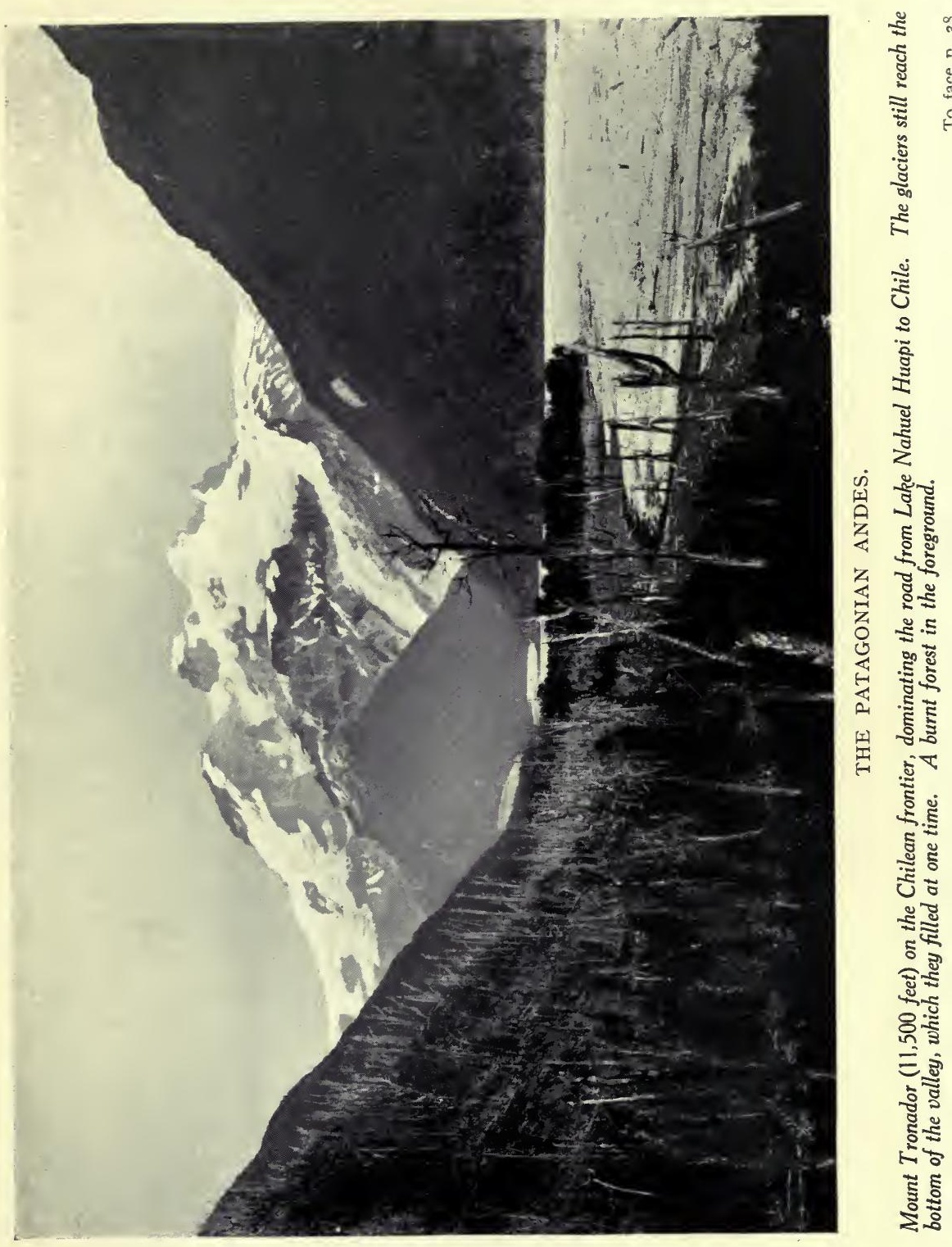



(November to March) that maize, which needs only the summer rain, can be cultivated without irrigation. But when we follow the Valle de Lerma southward from Salta the maize harvest becomes more and more uncertain, and it is no longer sown in dry soil when we get to about twenty miles from Salta, in the latitude of the confluence of the Arias and the Juramento. However, the summer rains, which are good for maize, are very injurious to the vine; they spoil the grapes. Thus the southern limit of the cultivation of maize in dry soil almost coincides with the northern limit of the vine. At that point we have the real beginning of the typical scenery of the valles.

The need of irrigation is due to the scarcity of rain, but it is accentuated by a number of causes which tend to increase the aridity. The valles are the scene of scorching day-winds, the zonda, like the Föhn of the Swiss Alps, which, there being no snow, dry up the water of the springs and of the irrigation trenches, or use the deposits left by the waters to form dunes, which they push southward, sometimes like veritable glaciers of sand. Moreover, the soil of the valles is generally composed of coarse and permeable alluvial deposits, which absorb the rain-storms immediately. There is at the foot of both sides of the hills which enclose each valle an immense and far-lying bed of imperfectly rounded shingle. This double zone of detritus is strangely desolate, for the vegetation on it is restricted to isolated bushes of jarilla and tola. From the sheepfolds on the mountains to the oases in the valleys one hardly meets a single house. The bed of the valley is not so desolate. A broad ribbon of sand marks the dry bed of a torrent, and on the clays of its banks, if the sheet of water underground is not too deep, one finds, in spite of the goats and asses and charcoal-burners, little forests of algarrobas, which the foundries use for fuel.

The modern alluvial beds, gravel and sand, represent 


\section{THE OASES OF THE NORTH-WEST}

the upper stratum of a considerable series of continental deposits which lie on the Paleozoic crystalline rock of the Andes. ${ }^{I}$ They chiefly consist of red sandstone and coloured marls, which crop up here and there through the alluvial covering and give the landscape a rugged character, worn by water and wind. There is no trace of humus: nothing to soften the vivid colours of the rock. Bodenbender, to whom we owe the first general attempt to classify the series, points out the importance of distinguishing the different strata in connection with the question of water supply and the conditions of human life.2 A complete geographical study would have to follow the geological description in detail. In places-on the eastern edge of the Sierra de los Llanos-the fine modern clays are in contact with the granites of the hills and form above them a thick bed that is rich in fresh water. In other places-southwestward of the Sierra de la Famatina, as far as the Bermejo-the outcrop is of red sandstone only. The tablelands of Talampaya and Ischigualasta, which are cut across by the gorges of the tributaries of the Bermejo, form one of the most conspicuously desert regions in the whole Republic. Wherever the gypsiferous marls of the Calchaqui are near the surface, the springs are saline. The undulations of the impermeable rocky substratum bring to light the water that gathers in the alluvial beds. Thus the streams which come down the Famatina range in the west disappear in the alluvial beds on the fringe of the Sierra, but re-appear presently in the oasis of Pagancillo.

3 This series, stretching from the Permian to the Tertiary, also includes, especially in the region of the sub-Andean chains, on the fringe of the Chaco, a number of marine strata (see Bonarelli, Las sierras subandinas del Alto y Aguaragie y los yacimientos petroliferos del distrito minero de Tartagal ("Ann. Min. Agric.," Seccion Geologia, Mineralogia, y Mineria, viii. No. 4: Buenos Aires, 19r3).

2 G. Bodenbender, Parte meridional de la Provincia de la Rioja y regiones limitrofes (Ann. Min. Agric., Seccion Geol., Minerol., y Mineria, vii. No. 3: Buenos Aires, 1912). 
Hence the valles are by no means wholly productive. The oases represent only a limited portion of them. It would be impossible to imagine a more striking contrast than that of the freshness and life of the oases compared with the surrounding desert. Screens of poplars shelter them from the zonda. The water runs along trenches paved with round pebbles under the spreading vines, at the foot of which, to economize water and space, lucerne is sown. Each garden feeds a family. Near the raw-brick houses there are large earthenware vessels, as tall as a man, in which the corn is kept. The hammering of the cooper fills the air.

In places the oasis is watered by a stream. In those cases there is on each side of the bed of the stream a narrow fringe, a continuous ribbon, of smiling gardens, which hide the path. Above and below Santa Maria a trench is opened every mile in the wet sands of the Rio. The water rises in it and fills it, and is directed by it toward one of the banks, where it is jealously collected and distributed. The water which flows from the irrigated fields and returns to the river, as well as that which the porous side of the trench has permitted to escape, goes to fill another trench and supply other fields farther on. The region of Los Sauces, in the northern part of the province of La Rioja, to the south of Tinogasta, shows a different type of irrigated cultivation, on account of the sandy course of the stream. The fields follow the feeding artery for about fifty miles. It is bled at the beginning of each bend, the waters remaining underground like hidden wealth.

In most cases however, the valle has no running water. What reaches it from the lateral quebradas is lost in the alluvial beds accumulated at the point where the quebrada enters the valle. In order to make use of it the cultivated areas are grouped on the cone of deposition; at least, that is the position in the great majority of the oases. A costa is a line of separate 
oases with their backs to the same slope. When the valle is narrow, the costas on either side of the sterile depression face each other, like two parallel roads. The water of the quebrada is never sufficiently abundant to irrigate the whole of the cone of the torrent. In order to create an oasis there, they have selected the most easily cultivable zone, which is usually the foot of the cone, where the deposits are finer and more fertile, retain the moisture better, and require less watering. The summit of the cone is composed of coarse stones, the first to be dropped by the torrent as it loses its strength. These are bad lands, where the water is wasted.

To meet the occasional drought and the danger of sudden floods in this fluvial zone, which is entirely the domain of the torrent, there is need of constant care and ingenuity. At Colalao del Valle the cultivated fields are five or six miles from the summit of the cone. After a number of successive years of drought the stream of water which reached them on the flanks of the cone lost half its volume and threatened to disappear altogether. They then built a stone dam at the outlet of the quebrada, and the water accumulates behind this during the night. At three o'clock in the morning the sluices are opened, and the stream, having thus nursed its strength, reaches the fields down below about seven o'clock. Then the sun and the wind rise, just at the time when the reservoir is empty, and by the middle of the day the stream ceases, and irrigation is suspended. At Andalgala, above which rises the glittering crest of Aconcagua, the waters of the melting snows which feed the torrent have not time to be " decanted" before they reach the valley. They come down laden with mud and sand. Above the points where the irrigation-channels begin the people make, in the bed of the torrent, a dam of branches of trees which filters the water. It is swept away by every flood that occurs, and is at once restored. 
What is even more admirable than the ingenuity of the vallista in utilizing the natural resources is the minute detail of the water-rights. It seems as if the vallista is even more cunning in protecting himself from his neighbour than in dealing with nature. The water-customs of these Andean valleys are worth an extensive study. The water does not belong to the State, and is not used by concession from the State. It is private property. The owner uses or abuses it as he pleases on the lands which he has selected. A man may be poor in land and rich in water, which he accordingly sells. There are frequent business deals in regard to water-rights, just as in regard to the soil and its produce. Appropriation of water often precedes appropriation of the soil. Many oases are communities where the non-irrigated lands are common to the whole population, and the irrigated fields alone are divided.

A primary group of customs regulates the relations to each other of communities higher up and lower down the same stream. At Catamarca the water of a certain stream is shared by Piedra Blanca and Valle Viejo. Piedra Blanca, in the upper part, absorbs the whole of the water for a week, but it must then suspend its irrigation during the following week and permit the stream to flow down the valley. The same evening, or the next morning, according to the season, the water reaches Valle Viejo. It is a custom known as the quiebras in the southern valleys of the desert side of Peru, where it allows different stages of cultivation to proceed simultaneously. In the same way, above Santa Maria, where several communities (S. Jose, Loro Huasi, etc.) receive the water brought by a channel from the Rio Santa Maria, each of them has a right to the full output of the channel for three days. At the end of that time the sluices are closed, and the water passes to the next community. There is grave trouble for any oasis that has its rights infringed or 


\section{4 THE OASES OF THE NORTH-WEST}

does not compel the communities higher up to respect them.

Amongst individuals the water-right is generally defined by a measurement of time, a certain number of days or hours-during which the owner controls the entire flow of the spring or stream. It is only when the water is more abundant that we find another method of fixing the right of water, defining it by bulk. The water is then said to be demarcada, as the unit is customarily the marco, or the volume which passes through an opening about twenty-one centimetres in width and eight in height. The marco has infinite divisions, and each subdivision has its own name-the naranja, the bombilla, the paja, and so on.

As all the water is utilized, and the rights of all are equally entitled to respect, the division of the water into marcos (demarcacion) is in practice merely a proportional distribution of it amongst those who have rights to it. If the sum total of rights expressed in marcos represents something like the total flow of a stream during an average season, in the time of low water it is disproportionate, and the water no longer flows to the tops of the marcos. In other words, the quantity of water granted to each rises or falls with the rise or fall of the stream itself.

Theoretically, when the water-right is defined in marcos it is permanent. Often, however, it is impossible to grant each proprietor a permanent title to the water. Even in oases where the water is "demarked," the turno-that is to say, the turn of the proprietors to have water-which is the absolute rule in the poorest oases, reappears during the months of scarcity, in winter, when there is no rain, and at the beginning of summer. It reappears also when the right of ownership has been broken up into fractions that are too small, and it is better to grant a larger volume of water for several hours instead of a constant stream of water which would be too scanty for profitable use. At 
Andalgala the "turn" is sometimes obligatory, and regulated by custom, in channels where the irrigating proprietors are too numerous; at other times optional, and settled by convention amongst the owners themselves, when water is scanty. At Valle Viejo (Catamarca), when the water runs low, they set up the mita ; that is to say, the sluices remain closed in each channel during four days out of eight, each proprietor in turn giving up his right to a permanent supply in order to have a double allowance when his turn comes. The turno is, therefore, a general practice. Everywhere we can see the farmers on the watch along the acequias, waiting for the moment to close their neighbour's trench with a pellet of clay and to let the stream into their own trenches with a blow of the spade.

The most minute precautions are taken in order that no one shall suffer injury. As the irrigation is always slower and less thorough during the night, they take it in turns to have the day and the night alternately. When the community receives the water from another community higher up the stream, the succession of "turns" amongst its members differs every time. The water comes down charged with sediment, pushing in front of it a mass of liquid mud, as the flush of a torrent does. It takes some time for the stream to become regular and clear. The first irrigator therefore exercises his right under unfavourable conditions. In the local phraseology the volcada de agua is not as good as the corte de agua, which means the irrigation that begins when the acequia is full.

Irrigation entails the services of quite a staff of arbitrators and administrators. The head men, who have jurisdiction of a higher order and secure the accurate distribution of the water amongst a number of channels or communities, are now, as a rule, officials of the administration, appointed by the provincial authorities (juez de Irrigacion at Catamarca, juez de rio at Rosario de Lerma). But the juez de agua of each 
community or each channel is a syndic elected by the interested parties. At Santa Maria the juez de agua is elected by the owners and confirmed by the Government. He controls irrigation throughout the department, settling all differences, submitting plans of work to a meeting of the owners, and assigning their respective charges in labour and contributions according to their rights.

This land of customs and traditions is also a land of lively movement. The briskness of the traffic is primarily due to continuous exchange between the various zones of the mountainous district. This large trade, so scattered that the railways could not dream of satisfying its needs, is carried, in the old fashion, on the backs of mules. The lively aspect of the roads between the tableland and the lower valleys of the region, the brisk interchange of goods between zones with different climates, is one of the common features of life on the Andes.

But the classic spectacle presents a different aspect in different latitudes. In Peru, and in southern Bolivia, the higher valleys-Jauja, Cuzco, the Pampas of Cochabamba and Sucre-have centres of dense population and agricultural wealth at a height of between 9,000 and Ir,000 feet. They raise cereals, and receive from the tropical districts (montañas and yungas) sugar, cane-brandy, cocoa, and coca-leaf. The valleys of the Argentine Andes are usually at a less elevation than the yungas and montañas of Bolivia and Peru. But they are not hot districts, and have not tropical vegetation. Frost prevents the harvesting of sugarcane at Salta, at a height of 4,000 feet. As to the cocaleaf, which is not as much used here as in the north, the Argentine valles do not send it to the tableland, but receive it indirectly from there, through the southern yungas. In default of tropical crops, the Argentine valles sow wheat and maize, which they sell to the 


\section{TRAFFIC ON MULES}

Indians of the cold districts of the Puna for wool and salt.

These commercial currents are of very ancient, probably pre-Columbian origin. Boman has discovered ears of maize in the prehistoric tombs of the Puna de Atacama.I The Puna, at a height of II,000 to I2,000 feet, is permanently inhabited, unlike the high valleys of the Cordillera de San Juan, which are occupied only during the summer season by Chilean shepherds. It is primarily a pastoral and mining region, but it has some tilled land, at more than 6,700 feet above the level of the valleys. The higher limit of annual cultivation in the cold districts, which is fixed by the summer temperature, does not fall in the same way as that of arboriculture in warm districts, because trees suffer from the winter frosts. The Indians of Cochinoca and Susques sow lucerne and barley for fodder, and the quinoa and potato for food. Transport between the Puna and the valles is carried on by the inhabitants of the Puna, and is not shared by the vallistas. They are especially active in the north, in the province of Jujuy. Belmar shows how important the sales of the Puna woollen goods were by the middle of the nineteenth century. ${ }^{2}$ These fabrics were used by the mill-owners of the Rio Grande de Jujuy to pay for the work of the Indians of the Chaco, whom they employed in the sugar-cane harvest. The competition of the manufactured products of Europe now menaces the domestic weaving of the Puna, just as the competition of the flour of the Pampa menaces the cultivation of cereals in the valles.

Besides this traffic of local interest the valles serve for a traffic of a higher, almost a continental character. It seems certain that during the pre-Spanish period

Eric Boman, Antiquités de la région andine de la République Argentine et de la Puna de Atacama: Mission scient. G. de Créqui-Montfort et E. Sénéchal de la Grange (Paris, vols. i. and ii. 1908).

- Belmar, Les provinces de la Fédération argentine (Paris, 1856). 
the road from the Peruvian tablelands to Chile avoided the inhospitable desert of the Puna de Atacama, entered the region of the valles to the east, and crossed the Cordillera in the latitude of Tinogasta, or even a little further south. That was the route of the armies of the Incas, which in the fourteenth century came as far as Maule. The pre-Columbian roads, of which Boman has found traces between the Valle de Lerma and the Valle Calchaqui, seem to correspond with this direction of traffic. By this route the long quechua passed. amongst the Diaguites populations. The conquerors followed the Indian guides. Almagro, in going from Peru to Chile, passed through the valles at the eastern edge of the Andes.

Later the valles were incorporated in the many variations of the historic high road, one of the first and busiest of Spanish America, which goes from the Rio de la Plata to Lima : a route both for armies and merchants. The plan proposed by Matienzo (I566) to make a road from the silver mines to the estuary of the Paraná, through the Valle de Calchaqui, seems to have been intended merely to improve a line of communication that had already been in use. Buenos Aires for a long time received European goods by this road. About I880 the Salta route recovered for a time its continental importance, during the Pacific War and the occupation by the Chileans of the maritime provinces of Bolivia.I At that time it was the only outlet for Bolivia.

But of all the forms of traffic that have enlivened the valles the most constant, and the form that has had the most profound influence on their existence, is the movement of cattle. The cattle trade has been of fundamental importance in the history of the colonization of South America. Animals were the only goods that could be conveyed any great distance. At the beginning

"See Brackebusch, "Viaje a la provincia de Jujuy," Bol. Instit. Geog. Argent., iv. 1883, pp. 9-17. 


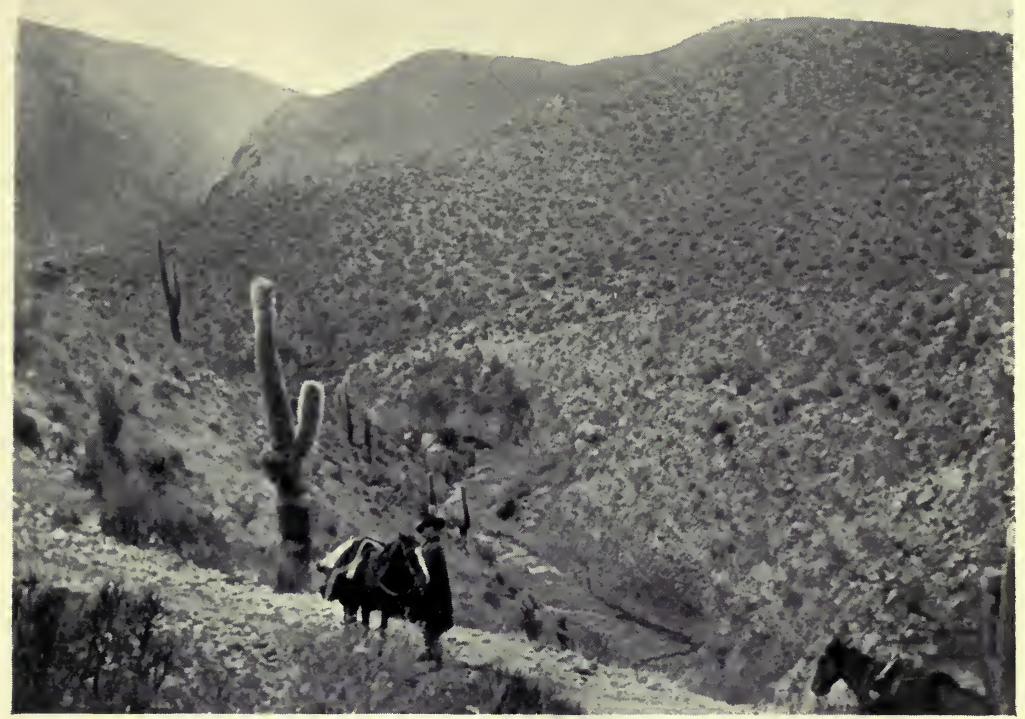

VEGETATION OF THE INTERIOR VALLEYS (ANDES OF THE NORTH-WEST).

Descent of Tafi del Valle, going to Santa Maria. The ravine is excavated out of the mass of coarse deposits which forms a fringe between the mountain and the valley. On this permeable soil the vegetation is particularly thin. Cactus. Photograph by the Author.

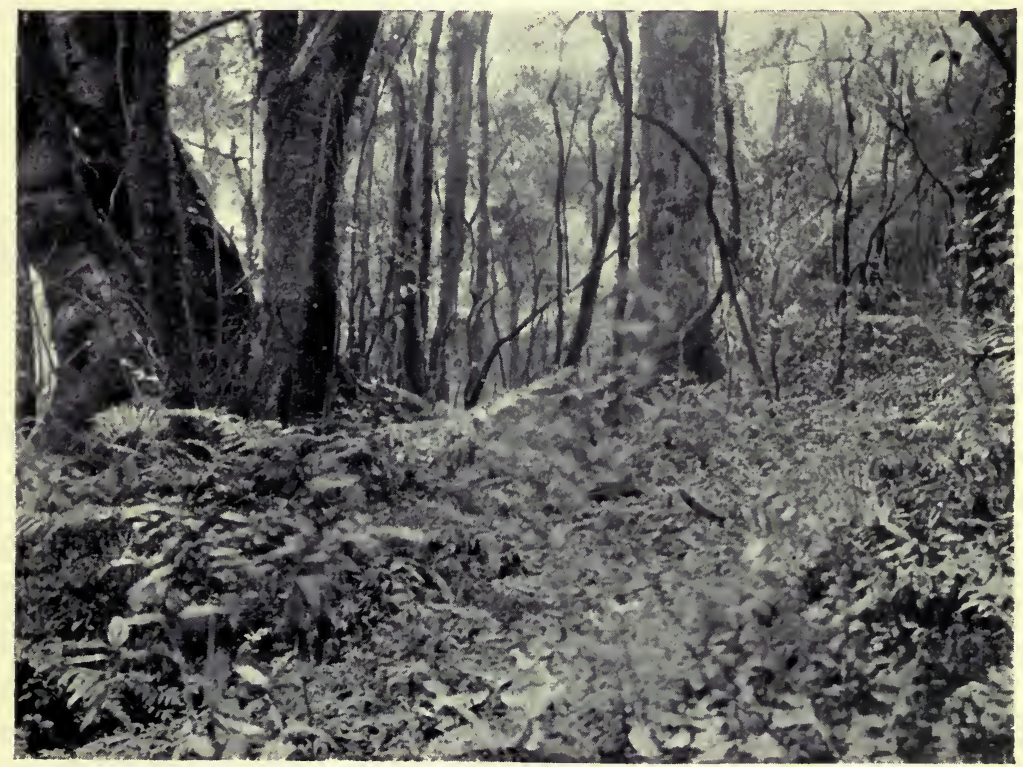

FOREST ON THE OUTER SLOPE OF THE SUB-ANDEAN CHAINS. Sierra de San Antonio (Salta province). Perennial foliage, creepers, ferns.

Photograph by the Author. 

of the conquest the productive regions of the continent, which supplied the export trade with Europe, were very limited in extent. Pastoral colonization began at once, and spread over a very wide area. Herds of oxen, for meat or draught, horses, and mules, made their way toward the centres of consumption: towns like Lima, Bahía, and Rio, the Peruvian mines, and the sugarrefineries of the north-east of Brazil, and later toward the yerbales of Paraguay or the seaports of the Caribs and the Rio Grande do Sul, where the jerked meat industry developed. The cattle routes converge upon these centres.

The export of cattle and mules from the Argentine plains to Peru was fully established by the close of the sixteenth century, and it seems to have continued without interruption ever since. Upper Peru is, however, not the only market on which the Argentine breeders lived. At the end of the eighteenth century D'Azara demanded that they should permit the sale of horses and mules to Brazil, for use in the mines. The cattle traffic with Portuguese territory had not then assumed the form of a regular commerce, and the Brazilians made raids on the north-eastern provinces for the animals they needed-60,000 a year, D'Azara says. I The export of cattle to Paraguay and Misiones was, on the other hand, of substantial economic importance in the eighteenth century. Before the Revolution, Rengger says, as many as 200,000 head of cattle passed yearly from Corrientes to Paraguay, which paid for them in maté and tobacco. ${ }^{2}$ This trade was kept up intermittently in the nineteenth century. The exports from Corrientes were especially important at the time when the Paraguay stock was reconstituted after the war (40,000 head of cattle in 1875$)$.

- Memorias sobre el estado rural del rio de la Plata en I801, Escritos postumos de D. Felix de Azara, published by D. Augustin de Azara (Madrid, 1847).

2. A. Rengger, Reise nach Paraguay in den Jahren 1818 bis 1826 (Aarau, 1835). 
Finally, the Chilean market was opened to the Argentine breeders about the middle of the nineteenth century. In the time of Martin de Moussy the convoys of cattle to Chile were so numerous that the lucerne fields of both slopes were stripped bare at the very beginning of the season; and they were rented at a high price. ${ }^{\mathrm{I}}$ Not only the mining provinces of the north, but central Chile also, bought Argentine cattle. The opening of the Chilean market was followed by a remarkable expansive movement in the pastoral colonization of Argentine territory. We can follow the progress of this not only in Martin de Moussy's book, but in all contemporary works of travel. Its chief theatres are the provinces of San Luis and of Santiago del Estero, north of the Rio Dulce, where Hutchinson, in particular, describes the activity of the ranches. ${ }^{2}$ Finally, after the Pacific War (1880) the nitrate district, taken from Bolivia and Peru by Chile, received a great influx of population, and works sprang up in the midst of the desert. The nitrate fields, wholly barren and doomed, under their shroud of grey dust, to an unalterable desolation, became at once one of the chief centres of consumption for Argentine stock.

It is difficult to give accurate details of the volume of trade in cattle in colonial Argentine. However, the facts given by travellers (though they often merely borrow from each other) suffice to show how important this traffic was in the life of the country and the extent of the zone that was occupied with it. As early as the middle of the seventeenth century Córdoba seems to have exported to Peru as many as 28,000 to 30,000

I The fattening of cattle for Chile was no longer done in the invernadas of Mendoza at the beginning of the nineteenth century. See an article on Mendoza in the Telegrafo Mercantil, January 31, 1802, which tells of the development of ranches on the Tunuyan. Mendoza and San Juan were their only markets, and they did not sell cattle to Chile.

2 T. J. Hutchinson, Buenos Aires y otras Provincras argentinas (translated by L. Varela, Buenos Aires, 1866). 


\section{THE REARING OF MULES}

mules annually. $x$ At the close of the eighteenth century, we read in D'Azara, 60,000 mules were exported; and Helms gives the same figure. ${ }^{2}$ The mules were bought young by Córdọba dealers at Buenos Aires, Santa Fé, and Corrientes, reared at Córdoba, and then sent to Salta, where they were sold in their third year to muledealers from Peru.

An article in the Telegrafo Mercantil of September 9, I80I (reproduced in the Junta de Historia y Numismatica americana, Buenos Aires, 2 vols., IgI4-5) contains very valuable information in regard to the mule trade. From I760 to I780 Salta sent between 40,000 and 50,000 mules annually to Peru. At Salta they were worth ten piastres each before they were broken in, and thirteen or fourteen afterwards; and they were sold at the age of four years. The arrieros, who conveyed European goods and home products (ropas y frutas), bought a large number of them. The Telegrafo complains that this trade has been gradually transformed. The mules now came from Santa Fé and Córdoba to Salta two years old, and after the invernada they were still, at fair time, barely three years old. They suffered much during the long journey to Lima, and the losses of the caravans were heavy. They could not be loaded for the journey, and, as the arrieros could no longer secure adult and strong animals, the freight to the tableland had risen, to the serious loss of merchants on the coast. The reply of a Potosi mule-dealer (December I3th) clearly shows that the last years of the eighteenth century had been marked by increasingly heavy demands from Peru for Argentine mules. In order to meet these demands the Córdoba breeders had developed production. The buyers, coming to Salta from Lima, Cuzco, and Arequipa, took, without dis-

- Azcarate de Biscay, quoted in H. Gibson, La evolucion ganadera in Censo agropecuario nacional Buenos Aires, 1909, vol. iii.

2 A. Z. Helms, Voyage dans l'Amérique meridionale (Paris, 1812). The journey was in 1788 . 
cussion or examination, the batches that were offered them. The correspondent of the Telegrafo complains bitterly of these caballeritos who came from Peru with their 100,000 piastres, and raised the price at Salta, alleging that their instructions were to get mules at any cost.

Robertson gave in I8I3 the recollections of a muledealer as to the convoys of mules between Santa Fé and the Andes, which had already ceased at that time. Each convoy or arreo comprised 5,000 to 6,000 mules. They came from Entre Rios, or even from the Uruguay, whence they were brought, after crossing the Paraná, to the Santa Fé ranches. The Santa Fé breeders owned the best part of the land on the left bank of the river. The expedition also included thirty waggons of goods and 500 draught-oxen; and fifty gauchos were in charge of it. The main expense was then tobacco and yerba. One feature of this mule traffic that is emphasized in all the descriptions is that it was divided into two stages, with an interval between them, for breaking in. As we have already learned from Azcarate, Córdoba Santa Fé, Santiago, and Salta kept the mules for two or three years before sending them to Peru. Córdoba and Santiago del Estero seem to have been important in connection with the industry of breaking in the mules.

The sending of cattle on foot to Bolivia and Chile is now only a subsidiary element of the national economy, but it is not yet quite extinct, as the table on p. 53 shows.

Whatever its point of departure, the traffic in stock always passed through the valles. Transport of cattle was particularly difficult in the Argentine Andes. The chief obstacles were not the elevation of the passes or the steepness of the roads, but the scarcity of water and the extent of the travesias, which were equally poor in pasturage and water, and had to be crossed rapidly by doubling the stages. The difficulties of the journey were very profitable to the oases that lay along the 


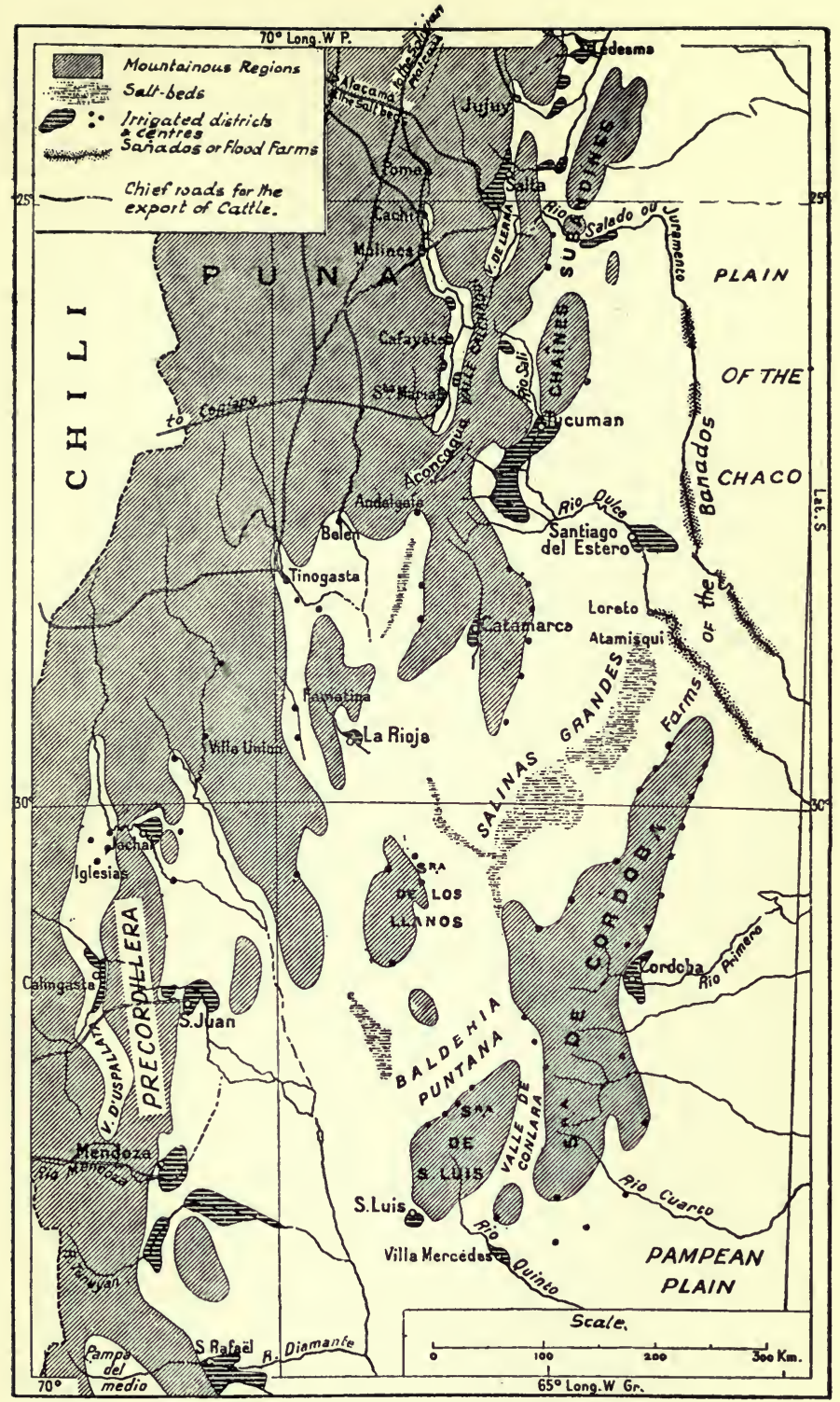

MAP II.-IRRIGATION IN THE WEST AND NORTH-WEST OF ARGENTINA.

Extent of the irrigations in the north (zone of the great summer rains), and the south (glacier zone). The historic industry of fattening sattle in the invernadas and the export of cattle to the Andean regions only survive in part. On the other hand large modern industries have developed at Tucumán, Jujuy (sugarcane), Mendoza, and San Juan (vines), and they supply the Buenos Aires market. 

route. The cattle-driver could not dispense with the hospitality of the vallista or dispute the price he cared to charge.

The length of the journey and the difficulty of keeping the animals in good condition in the poor pastures of the breeding districts made it advisable to stay longer in the oases. There thus arose lucerne-farms-the invernadas-to receive and fatten the cattle which passed through. Lucerne is the characteristic and most profitable produce of the valles. It is grown

\begin{tabular}{|c|c|c|c|c|c|}
\hline & Igro & IgII & 1912 & I913 & 1914 \\
\hline $\begin{array}{l}\text { Export of Cattle : } \\
\text { To Bolivia .. } \\
\text { To Chile .. }\end{array}$ & $\begin{array}{r}3,600 \\
61,200\end{array}$ & $\begin{array}{r}6,600 \\
87,500\end{array}$ & $\begin{array}{r}6,200 \\
68,400\end{array}$ & $\begin{array}{r}6,300 \\
58,800\end{array}$ & $\begin{array}{r}4,800 \\
28,300\end{array}$ \\
\hline $\begin{array}{l}\text { Export of Mules : } \\
\text { To Bolivia .. } \\
\text { To Chile .. }\end{array}$ & $\begin{array}{l}2,700 \\
2,300\end{array}$ & $\begin{array}{l}4,600 \\
3,200\end{array}$ & $\begin{array}{l}7,900 \\
5,000\end{array}$ & $\begin{array}{l}8,300 \\
2,600\end{array}$ & $\begin{array}{l}2,500 \\
3,500\end{array}$ \\
\hline $\begin{array}{c}\text { Export of Asses: } \\
\text { To Bolivia }\end{array}$ & 9,000 & 10,500 & I 5,000 & I 5,600 & $14,400^{1}$ \\
\hline
\end{tabular}

I Imperfect statistics given by Poncel for the province of Catamarca give us some idea of the respective shares of the various Andean districts in the export of Argentine cattle about the middle of the nineteenth century. In 1855 the province of Catamarca sold 2,700 head of cattle ( $x, 300$ to Chile, 200 to Bolivia, 600 to San Juan and Mendoza), 3,200 mules (2,500 to Bolivia 600 to Salta-which also were for Bolivia), and 1,200 asses (700 to Bolivia and 400 to Salta).

wherever there is an assured supply of water, and is invariably found in the upper section of the system of irrigation-channels ; the cereals are sown lower down, and are the first to suffer from drought. In the quebradas, where space is more limited, the lucernefields cover the entire oasis. Every cattle track has a corresponding line of invernadas, which is often completed on the opposite slope by a last group of lucerne-farms where the beasts recover from the journey before they are sold and dispersed. 
Besides the official routes there have for a long time been clandestine tracks, through more difficult ravines. by which stolen cattle were conveyed with impunity. Guachipas was the gathering place for cattle of suspicious origin, and, to avoid being seen in Salta and Jujuy, they passed through the Quebrada del Toro or the Quebrada d'Escoipe. When Brackebusch visited Guachipas in I880 the inhabitants still kept something of their reputation as smugglers.

A map of the cattle-tracks which are still used in the Argentine Andes is a complicated network in which we can trace two main directions, crossing each other at right angles. One set of tracks leads to the west, toward the Pacific coast, the other set to the north, toward the Bolivian tableland.

The cattle traffic is now restricted to Chile. It survives at San Juan, Jachal, Vinchina, and Tinogasta. The cattle descend to Chile about Coquimbo, Vallenar, or Copiapo. But the trade is now busiest in the region of the saltpetre-beds. The roads lead from the Valle de Lerma and the Valle Calchaqui toward the tableland by the Quebrada del Toro or the Quebrada de Cachi or de Luracatao, crossing lofty passes at the foot of the Nevados of Acay and.Cachi, and reuniting between Santa Rosa de Pastos Grandes and San Antonio de los Cobres to cross the Puna de Atacama. Vegas (pastures) and fresh water are scarce here. The track passes interminably by depressions covered with a carpet of glistening salt, dominated by volcanic crests. It is used in every season of the year, but in winter the caravans are exposed to the cold wind laden with snow, the viento blanco. San Pedro is the port in this desolation. Here there are, on the flanks of the enormous cone of Licancour, fields of lucerne and groups of figs and algarrobas. The cattle are left there for a few days' rest, to prepare them for the last stage, the Calama oasis on the Antofágasta railway.

The centre of this trade is Salta, or, rather, the little 
village of Rosario de Lerma, nine miles south of it, where most of the caravans are formed. The saltpetre works make yearly contracts in advance with the Rosario dealers, fixing the number and price of the beasts to be delivered at Calama. The cost of transport includes, besides the pay of the cattle-drivers - eighty to a hundred piastres a journey-the shoeing of the mules, the rent of pasture at San Pedro, and the value of the beasts which die on the way. In I9I3 the number of animals exported by this route was put at 30,000 . The saltpetre works buy also draughtmules for their waggons. Draught-mules must be heavy, and only animals over five feet in height are sent to Chile. Bolivia is now the only market for the smaller mules and for asses.

The trade in mules in its traditional form and the industry of breaking-in still flourish at Santa Maria. The mule-dealer's business is very different from that of the cattle-dealer. The mules are so tough that it is possible to send them by roads which would be unsuitable for cattle.I The journeys are longer, and the contracts are less settled in advance. Moreover, breaking-in is a delicate operation that requires experience. The survival of the mule-trade at Santa Maria is an example of the maintenance of an industry owing to the presence of skilled handicraft. The men who break in the mules at Santa Maria have a remarkable caste-pride. Their first job is to go to Santiago or Córdoba to buy the mules. They bring them back to Santa Maria by way of Catamarca or the valley of Tafi. At Santa Maria the mules are broken in, then taken to the lucerne-farms at Poma to be put into good condition. There they remain in pasture for several months; and at length, when the season is suitable, the little band of Santa Marieños gathers together and,

I For instance, herds of mules are taken from Abrapampa, on the line of the Quiaca, to the saltpetre mines of Antofágasta, whereas every effort to convey cattle by this route has failed. 
driving the now docile beasts in front of them, and putting no loads on them in order that they may keep fresh, make for the fair at Huari in Bolivia, or even as far as Sucre. There they sell at a hundred and fifty piastres each the animals which they had bought for half that price before being broken in. The number of mules hibernating at Poma is about 4,000.

The business done in the fairs of the southern Andes is very varied in character, but their main function was always as markets for stock. ${ }^{I}$ They are held in March or April, when the rains do not fall, but pasture is still abundant and travelling easy. The fair at Vilque, north of Lake Titicaca, is no longer visited by dealers in Argentine mules. The Salta fair which was held at Sumala, near Rosario de Lerma, has ceased to be important; at the close of the eighteenth century it was the chief centre of the mule-trade. The fair held at Jujuy is still, like the annual pilgrimage to the Virgen del Valle de Catamarca, one of the great dates in the life of the Andes. In the eighteenth century it was mainly a cattle-fair, but it is now frequented only by mule-dealers. The development of the railways is gradually causing it to decline.

The cattle-trade has long been really a form of barter. The Argentinians who took their herds to Peru brought back with them European goods that had come via Panama and the Pacific. At Jachal direct communication with Argentina is still so costly that they prefer to get many manufactured articles from Chile. Everywhere else, however, the sellers of stock take payment in cash. The Santa Marieños bring back from Bolivia only a few bags of coca and, for chief payment, letters of exchange, which they cash in the Salta banks when they return. Their gains swell the profits of the merchants of Salta, Catamarca,

I There is an interesting study of fairs on the elevated tableland by G. M. Wrigley, "Fairs of the Central Andes," in the Geographical Review (New York), vii. 1919, pp. 65-80. 
and Jujuy, who get their goods at the large importing houses of Buenos Aires. It is the first form under which the influence of Buenos Aires reaches the valles. It gets their custom before it begins to absorb their produce.

A large proportion of the stock sent to Chile now comes from the Andean valleys themselves. The most arid and desolate regions round the oases breed only goats and asses; but as soon as the soil improves sufficiently to give a better vegetation, it is found good enough for a hardy and tenacious breed of horned cattle. The land is divided into large ranches, and the owners have also lucerne-farms, either individually or communally, the tillers of the oasis each putting in their beasts, which wander about in small groups without control. During the summer they go of their own accord up to the cerros, where the rains have brought out the vegetation, and drinking-water is found in the ravines for several months. In the winter they return to the valley, within range of the reservoirs and permanent acequias. Bodenbender gives us a few details about movements from place to place owing to such differences, as they are in vogue in the western part of the province of La Rioja, in the district of Guandacol. There the herds are taken during years of drought up to the mountains of the west.

Apart from the Andes, the zone which used to feel the influence of the trans-Andean markets has been steadily reduced in the last forty years. At one time it comprised the whole range of the scrub, and even overflowed upon the prairie region, but it is now limited to the nearest cantons to the fringe of the mountains. Over the greater part of the monte the cattle are now sent in other directions; either to Buenos Aires or to other Argentine towns with a growing population, such as Córdoba, Mendoza, and Tucumán.

The rupture of commercial relations with Chile has, 
however, not made any notable change in the pastoral industry. Pastoral life in the scrub has very uniform characters. It is chiefly dominated by the question of water-supply. Natural open water is scarce, and the cattle can drink only where man's industry makes it possible. The problem of taming the beasts, which the breeders on the prairies have not always been able to solve, is simplified by the scarcity of water. There is no need to hunt the cattle, no periodical rodeos, when the herd is drawn in every night by thirst to the water-supply. Advance in colonization means the provision of wells and reservoirs (baldes and represas), without which the breeders cannot occupy the plain permanently, but have to fall back during the dry season upon the few streams that cross it. The word balderia means districts where the presence of a sheet of water not far underground has enabled them to form a system of wells. The best known is the Balderia Puntana, in the northern part of the province of San Luis.

Of the regions apart from the Andes which still depend on the Chilean market it will be enough to mention two, which may be regarded as typical. The first is the Chaco Salteño, on the eastern slope of the Sierra de la Lumbrera. The Lumbrera is a lofty anticlinal range of limestones and red sandstones, which pass to the west underneath the clay of the Chaco plain, and separate it from the great longitudinal sub-Andean corridor, which was followed by the old road, and is now followed by the railway from Tucumán to Jujuy. Colonization began beyond the Lumbrera in the eighteenth century by passing round it, from south to north, by the valleys of the Juramento and the San Francisco (which joins the Bermejo). The ranches, which employed the Indians-the occupation of the Chaco at this point being pacific-bordered the Bermejo and the Rio del Valle, which flows from the Lumbrera range toward the former bed of the 


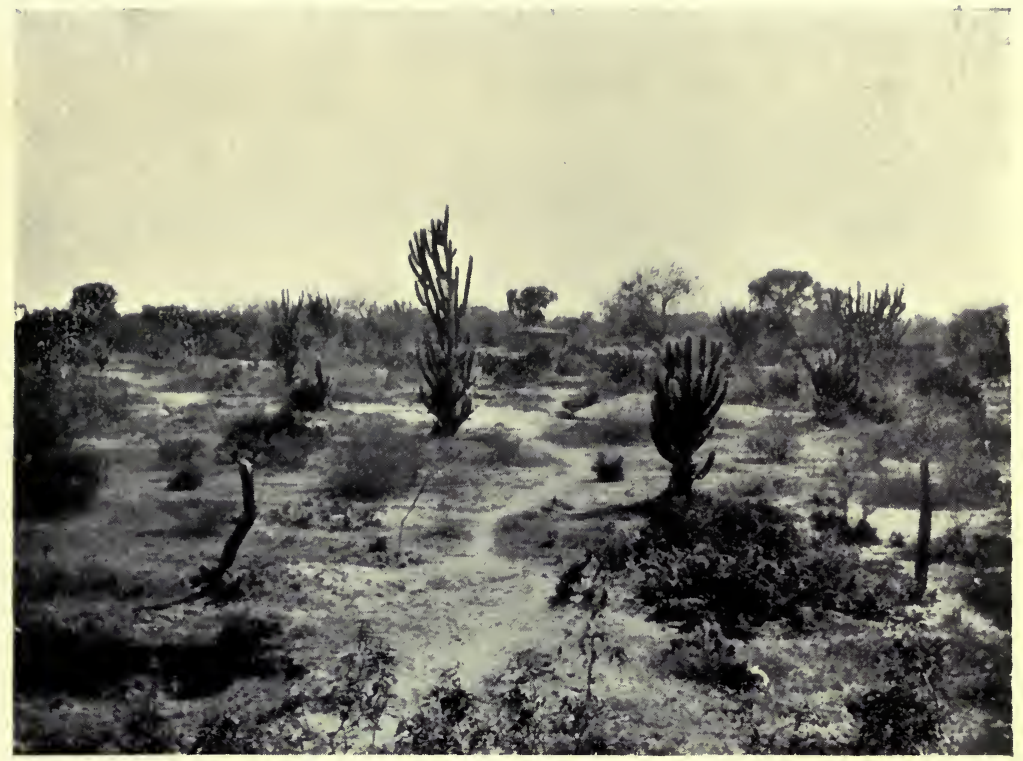

DRY SCRUB OF THE CENTRAL CHACO.

On the Añatura line (province of Santiago del Estero). Cactus. The leafless tree in the foreground is a red quebracho. The leafy trees are white quebrachos.

Photograph by the Author.

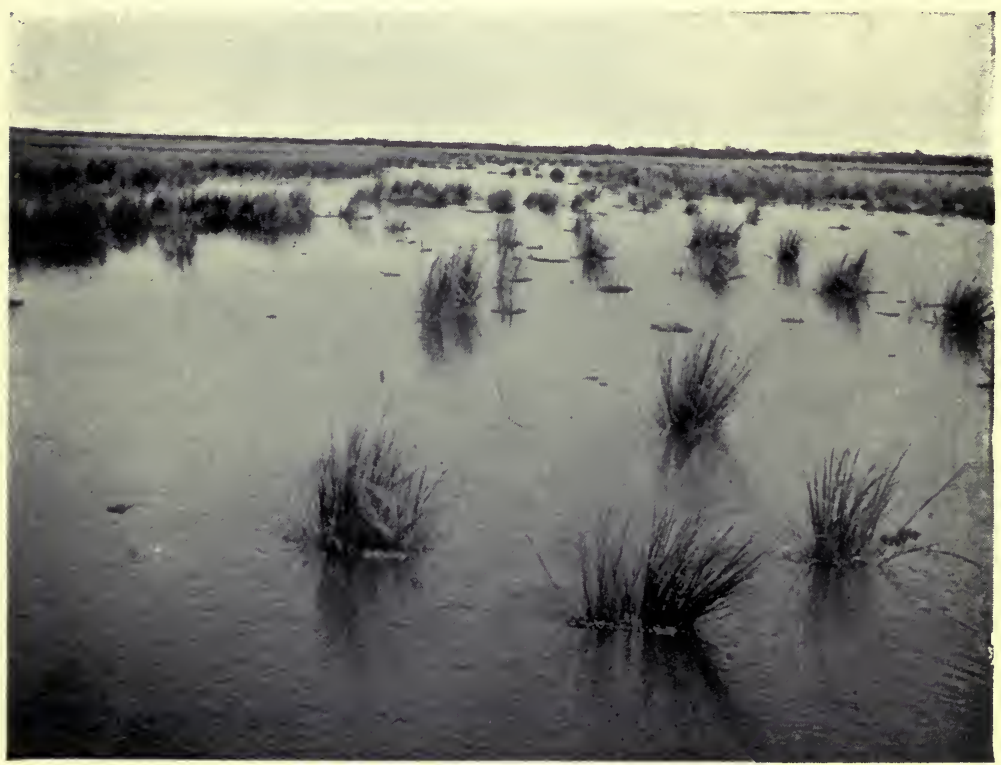

MARSHES (ESTEROS OR CAÑADAS) OF THE EASTERN CHACO.

On the Tartagal line (province of Santa Fé). It is by means of these marshes, which form in the forest, that this part of the plain is drained. Photograph by the Author. Plate V.

To face p. 58 . 



\section{ROUNDING UP THE CATTLE}

Bermejo, and washes the foot of the range at the edge of the plain.

The cattle live in the scrub during the summer, when the rains have brought out the grasses. In winter they go up to the moist forest, with perennial vegetation, which covers the flanks of the range. $I$ The comparative abundance of water lessens the labour of the breeders and, at the same time, the discipline of the herds. When the time comes, the whole ranch is mobilized for the purpose of collecting the adult cattle and making a convoy of them. Horsemen, with the double leather apron which hangs at the saddle-bow to protect them from the branches, ride up the range with their dogs and plunge into the scrub. The savage beasts are rounded up and held at bay. The procession is formed, and sets out, either by the rugged paths across the forest and mountain or along the easier tracks over the plain to Embarcacion or Lumbreras, where they reach the railway. If buyers from the sugar-refineries at Jujuy do not take them, the cattle are put into trucks and sent to the Salta market, where there are sales all the year round. At Salta the beasts are fattened on the lucerne-farms before crossing the Cordillera. There is hardly any tillage, either because the winter drought makes the result dubious or because the breeders are not good at agricultural work.

The Sierra de los Llanos in La Rioja is another centre for extensive breeding. From the railway, which follows the range at some distance, between Chañar and Punta de los Llanos, before it reaches La Rioja, no one would have the least suspicion of the importance and life of the region. It is, nevertheless, one of the main foci of Argentine history. It has proved a cradle of population and wealth. It was there that Quiroga and, later, the strange adventurer who was known by the nickname of the "Chacho" gathered the strength

I On Aconcagua also the moist forest serves as winter pasture for the cattle from the ranches. 
that enabled them to dominate part of Argentina. Colonization is even older here than in the Chaco Salteño. It occupied two distinct periods, separated by a long interval. At first it advanced from north to south, passing round the foot of the Sierra. It is marked by a line of springs, poor but permanent, the waters of which are absorbed as soon as they flow down to the porous alluvial beds of the plain. They appear much in the names of the district-agüitas, aguaditas, and so on, abound. The road from La Rioja to San Luis passed these springs, and some population grew up about them. Thus the two sides of the range-the costa baja in the east and the costa alta in the west-became inhabited. . The estate of Facundo is one of these aguaditas of the costa alta.

The two costas form the historic territory of the Llanos. It was from there that colonization swarmed over the plain long afterwards. This expansive movement began about $185^{\circ}$; that is to say, at a time when the breeders enjoyed comparative peace and security, and especially when the invernadas of San Juan and Mendoza were developed, together with the export of cattle to the agricultural provinces of Chile. The price of stock rose, and the unoccupied land became of value. The occupation and exploitation of the plain was the work of the last two generations. They pushed on to the very edge of the salt lakes, leaving no vacant space. The travesias which surrounded the narrow inhabited zone of the costas were filled with life. The Sierra and its two costas are no longer an oasis in the desert, as they were in the time of Sarmiento; though they still differ from the remainder of the pastoral zone in the density of their population and the variety of their resources.

The early date of the colonization may be traced in a special system of tenure, though this is also found in parts of the provinces of Catamarca and Santiago del Estero. On the plain the right of ownership was 
obtained in the nineteenth century by purchase or by concessions of public lands which belonged to the provincial Government. They were allotted in very large estates, and these, intact or broken up, are the actual ranches. In approaching the foot of the range one passes estates in the mercedes. The name indicates concessions that date from the colonial epoch, and they are, in all parts of South America that were early colonized, the source of land-ownership. But what is peculiar to the mercedes of the Llanos is that they have never been divided amongst the heirs of the first owner. ${ }^{I}$ Sometimes the number of co-proprietors is small. They are conscious of their relationship to each other and know the value of the rights of each. The merced is in that case only an undivided property held in common. Sometimes, however, the numbers of comuneros is so great that they have lost count of the exact share of the merced which belongs to each of them. The merced feeds a whole population, legitimate heirs and usurpers mixed together. In these cases it is a real communal property, and one might compare it, in spite of its different origin, with the Indian communities which exist in Argentine territory as well as that of most of the other Andean States.

The economy of the Llanos is less simple than that of the Chaco Salteño. There is agriculture as well as breeding. There is not much rain, and it is confined to the summer months. The mean rainfall is, no doubt, higher than what we find at La Rioja (about 30 centimetres), but it is not good enough to dispense with irrigation. The aguadas, springs and brooks at the foot of the range, are the only provision of permanent water, and it is very limited. The oases watered by these springs and brooks cover only a few acres at

I The title of the merced often shows clearly the attraction which the springs at the foot of the Sierra had for colonists. The land of the merced of Ulapes is defined thus: "The spring and the land within two leagues of it in every direction." The spring is the centre. There its protecting deities live. 
the foot of the steep cliffs of the range. It has not been possible to cultivate the land far from the mountains. At Chamical a trench that was made to convey water to the railway dried up. All that can be done is to follow for a few miles with a line of wells a subterranean stream of fresh and not very deep water. At Bella Vista a comunero has dug an acequia several miles long, and he sells the water at a rate of five piastres for forty-eight hours. But when it reaches the end of the acequia, it is lost between the trench and the field to which they would conduct it. At Ulapes, though it is one of the chief centres, it takes the full outflow of the spring during sixteen hours to irrigate one cuadra (a little over two acres), and each man's "turn" is for seventeen days. The entire oasis measures about fifty acres. At Olta the thin stream of water is surrounded by so many cupidities that the "turn" comes only every fifty-eight days, so that each field has to live fifty-eight days on one watering. At Catuna where a trickle of brackish water is eagerly collected at the foot of a dejectioncone, the water-right is regulated by an arrangement of turns that covers ninety days, so that plants die of thirst in the interval. The plots vary according to the quantity, quality, and regularity of the water. The orange-tree is the most exacting, the fig the most tenacious, of the trees. The poorest oases consist only of a few gardens of dusty fig-trees.

However small it is, the oasis always stands for a rudiment of communal life, a poblado, a centre round which life is organized in this pastoral, anarchic, amorphous world. Land that has a water-right is regarded as detached from the merced and never remains undivided.

Besides these properly irrigated lands there are the bañados: cultivated plots in the hollows, where the moisture left by the storms is concentrated and preserved. These are much more extensive, and they 
are very irregularly distributed. Inequalities of the alluvial ground that almost escape the eye are suffcient to direct the streaming of the water after rain, and it is quickly absorbed. Man assists nature as well as he can, and one sees everywhere tiny ridges of earth across the paths, for the purpose of diverting the water to the plots. These are the tomas. When you follow a toma downward, you see it after a time pass under a hedge of dry thorn, and this encloses a field, a cerco. The crops have to be jealously guarded against the cattle which roam in the scrub. The cercos are sometimes so numerous that they give the impression of a regular agricultural district. Most of them are planted with maize. The maize harvest rarely fails in the summer, for it is then, on account of the regular rains, that the maize grows and ripens. When the ears have been gathered, the cattle are let into the cerco, as maizestraw is excellent fodder. But wheat also grows well in the bañados. Provided the year has had a few late showers, the wheat sown in autumn stands the winter drought more or less well, and ripens after the early rains, at the beginning of summer. The Llanos produce a hard wheat; it is not milled, but eaten, like rice, in the grain. There have been times when the Llanos have exported wheat. The census of 1888 gives the Department of General Belgrano, on the eastern slope of the Llanos, an area of 900 acres under maize and I,900 under wheat. When the Chilecito railway was constructed, this wheat competed with that brought on mules from Jachal, in the mining district of the Famatina range. Like the gardens in the oases, the cercos may be divided, and they are the personal property of those who cultivate them.

Sowing and reaping are, however, mere episodes in the life of the Llanero. He is mainly occupied with cattle-breeding. The quality of the pasture differs considerably according to the nature of the soil and the good and bad character of the season. Sometimes 
it forms a thick carpet under the brushwood, but in other places it is poor and there is nothing but the leaves and pods of the algarroba. If the herd is too large, the grass will not grow again; the breeder recognizes at a glance the campo recargado-the field which has had its capacity overstrained. The pasture has to be carefully nursed. But the most urgent problem is to get a supply of water for the cattle. Round the Sierra the underground water is often fresh, and there are plenty of wells. Still, in order to avoid having to draw the water, they dig large trenches at suitable spots in the clay, and round these they arrange the earth that has been dug out, with an opening toward the hills to catch the water when it is raining. These are the represas. As in the case of the bañados, ridges of earth direct the stream to the represa. It is surrounded by a hedge as carefully as the field is. On the plain rain is rare, and the represas are usually the only reserve. They have to last the whole year; even two years if there is a particularly dry summer that prevents re-filling. Thus they become sometimes veritable lakes. From a distance you can see, above the top of the brushwood, the bald curve of the mound of beaten earth which encircles them. The water flows over it when there has been much rain. The mound is sometimes $4 \frac{1}{2}$ to $5 \frac{1}{2}$ yards high; as it is at Tello, between the Sierra d'Ulapes and the Sierra de los Llanos, where the San Juan coach used to change horses.

The represa is the real centre of the estate. The house is built near it, and guards the entrance. From early morning until dusk the cattle come to it, singly or in groups. The rancher admits them, lets them drink, and closes the gate behind them. If the thirsty cattle have not his mark and belong to a neighbour, he sends them to drink at their own represa; but he gives water to lost beasts, from a distance, whose owner will presently come for them. Near the represa 
is the enclosure (potrero) for calves that have just been born. The cows come there every morning, and they are milked for a few months to make cheese. Like the cerco, the represa is the personal property of the man who made it, or of one who has inherited it and sees to its upkeep.

The cattle of the Llanos move a good deal. There are certain irregular migrations, and others that are periodic or connected with the seasons. Everywhere on the fringe of the Sierra the cattle remain in the ravine and on the foot-hills during the winter. In the summer they return of themselves to their querencia on the plain. The irregular migrations are due to scarcity of water or pasture. Driven by hunger, the beasts travel a long distance of their own accord. They mingle with other herds, sometimes so far from the ranche where they were born that no one recognizes their mark. Sometimes, again, the rancher himself goes, when his represa is dry, to ask hospitality in some more favoured canton. He is fortunate if the drought has not been general; if part of the country has been spared and can offer a refuge.

But it sometimes happens that the whole district has suffered, and the land is naked and scorched everywhere. There is then no help except a long journey, to San Luis or to the lucerne-farms of San Juan, for the cattle. The misfortune of the Llanos sends up at once the rent of the invernadas all round. A general evacuation of the cattle is a desperate remedy, and is, in fact, often impracticable. During the whole summer the men wait patiently, hoping for the end of the drought. There is room for hope until April, when storms are still possible. If the month ends without rain, it is too late to remove the exhausted cattle; the stages across the desolated country are too severe.

The memory of the worst years of drought-the "epidemics," as the Llanero calls them-lives for a 
long time. They make a deep impression on the popular imagination, and legend makes plagues of them, in the Biblical way. The drought of 1884 was particularly disastrous. The herds were destroyed, and families that had been wealthy the day before set out on foot, " having nothing to put a saddle on": a touching picture of misery for this race of centaurs, people who feel themselves mutilated when they are not on horse. The rain returns next year. The pasture grows all the better because the herd is smaller, and the Llanos give the traveller who crosses them an exaggerated impression of their natural wealth.

Until quite a recent date the cattle reared in the Llanos were destined exclusively for Chile. Dealers from Jachal or Tinogasta came in the autumn, and the cattle passed the winter in the invernadas at the foot of the Cordillera. From the Sierra d'Ulapes, which is a southward continuation of the Llanos, the cattle destined for Chile were first sent to San Juan. They took one or two weeks to reach it. Five men were needed for a herd of a hundred beasts : eight for a herd of two hundred. The caravan was directed by an estanciero (rancher) or his capataz, or by dealers who came originally from the Llanos.

Exports to Chile have not entirely ceased. In I9I3 the dealers from Tinogasta and Jachal, who had not appeared in I9I2, came back. The southern part of the Sierra d'Ulapes, which is some distance from the railway, reserves its cattle for San Juan. The cattle are, however, more and more sent by rail to the coast. In the Sierra d'Ulapes the dealers from Villa Mercedes, which has become one of the great markets of Argentina, come every year, rent an enclosure (protrero), and collect in it, one by one, a herd of cattle, which they then take away on foot. They are sold at the fair at Villa Mercedes, and they disperse in every direction toward the fattening zones of the Pampa.

This commercial revolution has led to a rise in the 
price of cattle, and this in turn has raised the value of land. When the value of the land rises, the methods of working it are necessarily improved, there is greater security, and thefts of cattle (cuatrerismo) become impossible. The farmers are not content merely to enlarge their represas or dig deeper wells. They divide the fields by fences-cheap iron wire stretched on home-made posts, or hedges of spines like those which protect the bañados. Thus pasture can be reserved untouched for the difficult months.

This subdivision of the land by fences began in the south, in the Ulapes district, in touch with the richer districts of San Luis and Córdoba. In the Llanos proper the practice has scarcely begun. At Ulapes it is even done on the mercedes. Each comunero, without opposition, encloses as much space as he can, and leaves his cattle outside, on the common land, as long as possible. He only brings them into his enclosed land when the common pasture is exhausted. This will bring about the end of the mercedes; and, indeed, communal ownership is not suited to modern conditions. The latest sign of progress is the appearance of lucerne fields. Lucerne can be grown on the bañados wherever anything else can be grown; and the creation of lucerne-farms will give the pastoral industry a security and stability it never had before, besides enabling the breeders to collect stores of dry forage and exploit the full pastoral capacity of the monte. 


\section{TUCUMÁN AND MENDOZA THE GREAT INDUSTRIAL ENTERPRISES}

Tucuman and the road to Chile-The climate and the cultivation of the sugar-cane-The problem of manual labour-Irrigation at Mendoża - Water-rights - Viticulture - Protection and the natural conditions.

THE great industrial forms of cultivation, the sugarcane and the vine, gave a new aspect to the scenery of Tucuman and Mendoza at the end of the nineteenth century. The increase of population and wealth which they entailed was so sudden, the economic advance so swift, that the owners of vineyards and the sugarmakers have now lost all recollection of the primitive industries which gave life to colonial Tucumán and Mendoza, and were maintained until the last generation. Nevertheless, if one compares Tucumán or Mendoza with some centre of irrigated tillage in north-west Argentina, one quickly perceives the original features which three centuries of history have given them. The system of land-tenure, water-rights, the distribution of the cultivated zones, and a thousand other features, show that the colonization is old. The exploitation of the soil and utilization of the water have not proceeded on a methodical plan, conceived in advance, which would make each piece of work-the dams and channels of distribution, for instance-subordinate to the whole. The engineers who constructed the great modern dams of Mendoza, San Juan and Sali, had not to create a region of new estates, but merely to 


\section{DAMMING THE WATERS}

improve the water-supply, which was used wastefully by the existing estates. There is nothing more suggestive than the contrast between these stone dams, built according to all the rules of hydraulics, and the network of irregular channels, following the accidental variations of the land and the slope, which preceded them, and to which they have been accommodated as far as possible. In some cases the primitive acequias could not be altered so as to start from the dam. The accumulations of water succeed each other down the slope, held up by a simple barrier of branches and earth which is periodically destroyed by floods. The modern flood-proof dam (dique nivelador), which cuts the torrent in its entire width, and enables them to make use of its whole volume, allows a certain amount of water to pass, for the use of the acequias lower down. This falls back into the broad, stony bed, exposed to evaporation and infiltration as it was before.

Long before the development of the sugar industry on a large scale, there was a typically urban life, added to the common fund of pastoral life, at Tucumán. The neighbouring cantons of the scrub-Trancas, Burruyacu, and Graneros-sent cattle and mules to Peru and Chile, like the other Argentine plains. But Tucumán drew still greater profit from its position as chief stage on the high road to Peru, at the point where the plain passes into the mountain. Primitive Tucumán was an excellent type of high-road village. The road determined its position at the point where the Sali had to be crossed. The first site of the town, near Monteros, was abandoned in the eighteenth century, when the high road to Peru settled in the sub-Andean region and ceased to run through the Calchaqui valley. The road sustained its chief industries, tanning and harness-making for the muleteers of the Andes, and waggon-making for the troperos of the plain. The road and the people travelling along it afforded an 
outlet for its wheat and flour, and facilitated the export of its tobacco to the coast-provinces. The waggon-owners were really contractors, conveying stuff at their own cost. Moreover, part of Bolivia came to make its purchases at the shops (tiendas) of Tucumán, and the merchants of the town took in exchange Bolivian ore for export. Thus the road built up a nucleus of available capital at Tucumán. This capital was invested, at the close of the nineteenth century, in sugar; and it has increased a hundredfold. Most of the works still belong to old fanilies of the town.

The sugar-region is comparatively small. It covers an area which has exceptional climatic features, owing to the vicinity of Mount Aconcagua. While the higher chains of the Andes further north are separated from the Chaco plain by lower ranges, on which the east winds leave their stores of moisture less freely, Tucumán has on its west the great mass of Aconcagua. It rises, a giant landmark, at the beginning of the plains, from which there is nothing to separate it, and gathers the clouds round it.

On the eastern slope of Aconcagua is the limit of the crescent of tropical forest, which begins about three thousand miles away, on the flank of the Venezuelan and Colombian Cordilleras, and is connected in the centre, in the equatorial zone, from Guaviare to Mamore, with the forests of the Amazon region. At its two ends it is reduced to a narrow belt which does not reach, in the east, the alluvial plains, the savannahs of the Orinoco and the scrub of the Chaco. The humid forest of the Argentine Andes is nowhere more luxuriant than near its southern limit, above Tucumán. There are no palms or tree-ferns, but the convolvulus abounds, and the evergreen trees are covered with epiphytes. Aconcagua is one of the sharpest climatological limits in the world. In the latitude of Salta one has only to go about I50 miles to pass from the moist forests 


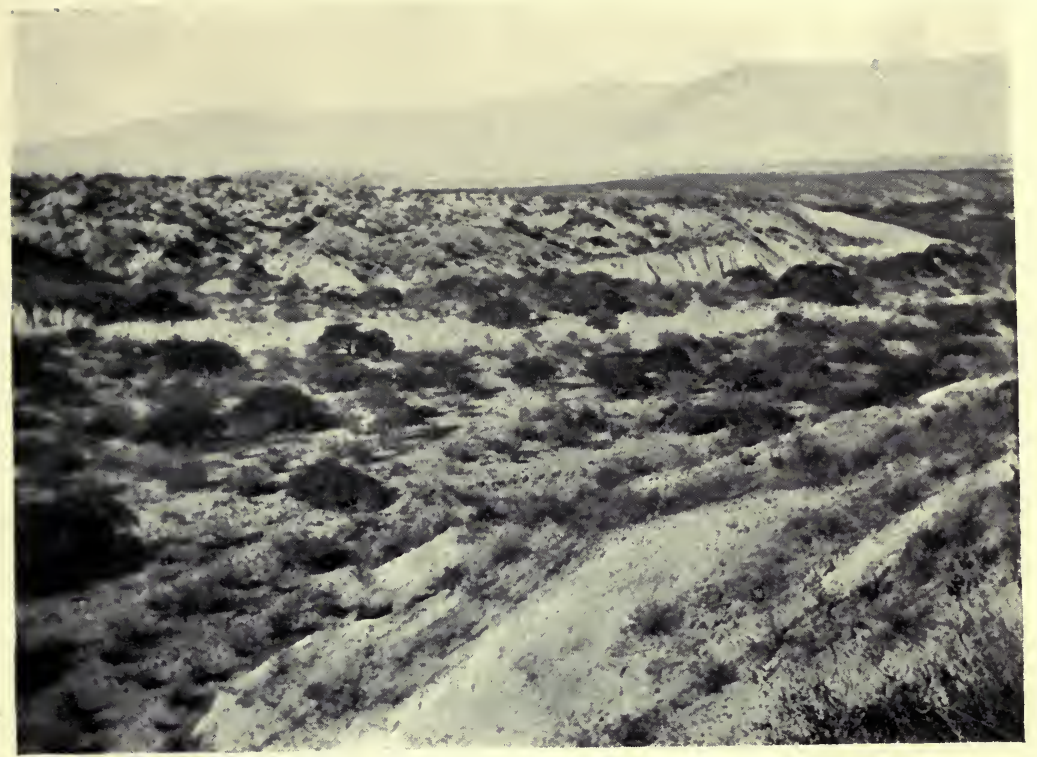

THE VALLE OF SANTA MARIA, NORTH-WEST OF MOUNT ACONCAGUA.

At the bottom of the valle one can see the sandy bed of the river as a white line in the foreground. Zone of torrential terraces, which follows the edge of the valle.

Photograph by the Author.

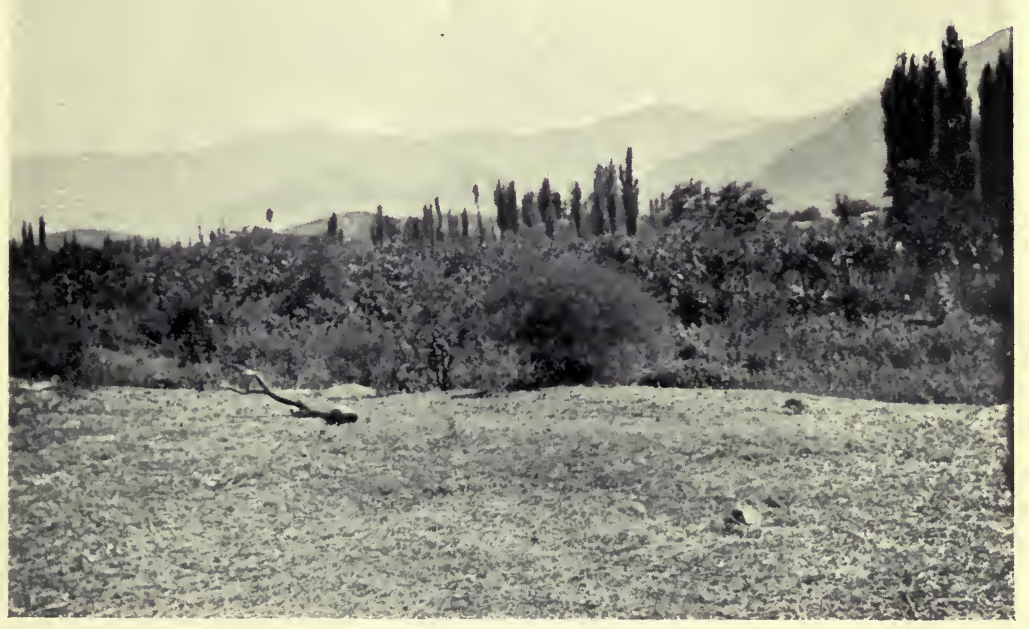

THE OASIS OF ANDALGALA.

At the western foot of Aconcagua, the snowy crest of which can be seen.

Photograph by the Author. 

of the sub-Andean chain of the Lumbrera to the arid valley of Cachi. On both sides of Aconcagua there are less than fifty-five miles between the sugar-cane fields won from the forest and the oasis of Andalgala, or that of Santa Maria, which are right in the desert zone. According as one approaches Aconcagua from the east or the west, one finds, from base to summit, either the successive stages of vegetation of the humid Andes-from forest to grain-sown prairie (paramo or pajonal)-or those which are characteristic of the arid Andes, from the spiny scrub of the valleys to the fields of resinous tola of the Puna. The contrast of climates is repeated in the character of the soils. Aconcagua contains in itself the entire Andes in miniature. At the foot of the narrow zone of Alpine crests, in the few square miles of the elevated valleys of Tafi and Pucara, there is a small agricultural and pastoral world, in a temperate climate, that has nothing quite like it elsewhere, narrowly confined between the forest and the desert. ${ }^{\mathrm{I}}$

The sugar district of Tucumán is not, properly speaking, an oasis ; that is to say, it is not an irrigated canton in the midst of a desert, but a moist patch in the heart of a less favoured region. The traveller who comes from the Chaco finds that the dust disappears from the moister air as he approaches Tucumán. The rainfall approaches 974 millimetres at Tucumán. Irrigation is a valuable aid to the farmer, but it is not indispensable. Maize is generally raised without watering, and part even of the sugar-cane crop is raised on land that is not irrigated. It is not the relatively heavy rainfall that has led to the development of the sugar-cane estates at Tucumán, but the evenness of the temperature, together with the atmospheric moisture

I The higher valleys of Aconcagua offer inexhaustible interest to the visitor. At Sancho (Pucara valley) there is a group of Italian colonists who grow maize and wheat: a unique fact, I believe, in the whole of this part of Argentina. The Tafi valley is mainly pastoral, the pastures of the valley being used in summer and the forest for winter pasture. 
and the rareness of frost. The mists which develop at the foot of Aconcagua form a protecting mantle above Tucumán which prevents nocturnal radiation. The nearer one gets to the mountain, the later, rarer, and lighter the frosts are. If, on the contrary, one goes out some distance westward toward the plain, the frost becomes more severe, and it is impossible to grow sugar-cane. Not only the humidity, but the contour also, has some influence on the changes of temperature and the distribution of frost. The depressions in which the cold air accumulates, in virtue of the well-known meteorological phenomenon of inversion of temperature, are more exposed than sloping districts, where the air circulates regularly and freely. The eastern limit of the zone spared by the frosts passes about thirty-five miles from the foot of Aconcagua. It has only been made clear by experiment, and one can still see there the traces of abandoned plantations.

The water-supply in the Tucuman district consists, primarily, of numerous evenly flowing streams which come down the eastern flank of Aconcagua (Lules, Famailla, Angostura, Gastona, Medinas, etc.). They join the Sali to the south of Tucumán. The Sali is an irregular torrent which rises in the sub-Andean depression to the north and Tucumán, and, after squeezing Aguadita between the north-eastern extremity of Aconcagua and the sub-Andean chain of Burruyacu, enters the plain at Tucumán. It then flows southward, meandering over a large bed of shingle in which it has not had force enough to excavate a valley, and the inclination of the land on its left bank (to the east) is toward the east and south-east. The lands on the right bank of the Sali are consequently better provided. with water than those on the left bank. The difference is so marked that, as the estates on the right bank get most of their supply elsewhere, the water of the Sali nearly all goes to the left bank. In IgI2 a siphon 
was actually constructed underneath the bed of the Sali to convey the unused water of the Rio Lules to the right bank. Lastly, to the north of Tucumán the Sierra de Burruyacu provides a few intermittent streams of water, which the estancias (ranches) formerly conducted, with great labour, to their represas. These do not suffice for irrigation on a large scale.

The sugar-cane was first grown at the gates of the town and, to the east, at Cruz Alta, on the left bank of the Sali. These were some distance from the mountain because, as there was less rain and the soil was fairly dry, the natural vegetation was less luxuriant, and it cost less to prepare the ground. ${ }^{I}$ The Central Córdoba Railway, which passes along the right bank of the Sali south of Tucumán, is the axis of another zone of cultivation and of old factories. Colonization afterwards went further west. A new provincial railway, describing a section of a circle, was grafted at Tucumán (I888-90) and Madria upon the Central Córdoba line. It keeps close to the foot of the range, the falda, and enables farmers to settle on it. The new estates have not confined themselves to the alluvial plain ; they have crept up the foot hills, and are constantly going higher. In the latitude of Tucuman the mountain approaches within eight or twelve miles of the Sali, and the possibilities of extension westward are strictly limited; indeed, they are already exhausted. Further south, on the contrary, the plain extends more than fifteen miles to the east of the provincial railway. West of Monteros, Concepción, and the existing line of works, there is a reserve of available land; there is room for a fresh advance westward. There is also room for expansion to the north-east, at the foot of the sub-Andean chain of Burruyacu,

I In 1894 it was calculated that ground that was not yet cleared was worth Ioo to I50 piastres a hectare at Cruz Alta, and the cost of clearing 150 to 200 piastres, whereas in the moist forest at the foot of the Sierra the land was worth only 75 to roo piastres, the cost of clearing it was double ( 300 to 350 piastres). 
where the frosts are slight. It is in this direction that most of the clearing is now going on.

These various districts do not offer quite the same conditions to the farmer. The Falda is the most suitable, not only on account of the rareness of frost, but because of the fertility of the soil, as the tropical forest has accumulated inexhaustible stores of humus. The sugar-cane returns are higher there than anywhere else. Irrigation is not necessary, but, on the other hand, the humidity reduces the proportion of sugar in the cane. Irrigation is the rule in the next belt, between the local railway and the Central Córdoba line (on the right bank of the Sali). On the left bank a large number of the estates must still do without watering.

The most original feature of the organization of the sugar industry at Tucuman is the maintenance of a class of independent cultivators, the cañeros, side by side with the large enterprises. This survival of small and medium properties is a fact to which we find no parallel in the other sugar districts of tropical America. ${ }^{x}$ Everywhere else, in Brazil and in the Antilles, the farms which worked up their own produce, on primitive methods, have been absorbed by the central works. The home-worker has lost his land as well as been ruined in his industry by the competition of the modern factory. At Tucumán, on the contrary, the sugar industry never passed through the stage of domestic production. It was set up in full development, some devoting their capital to building works, others to growing the cane. Irrigation seemed from the first to dictate a concentration of ownership; the refineries at Cruz Alta constructed costly special canals to bring the water of the Sali. It is only large proprietors who have the resources needed to carry out work of this kind, and sufficient influence to secure permission to conduct the water over adjoining estates. However, the law of 1897 reorganized irrigation and withdrew

Except, perhaps, in Barbadoes. 
the water-supply from the control of a few privileged big capitalists. Public works, undertaken by the provincial authorities, brought the water within the reach of every farmer. Since 1897 the number of waterconcessions has risen from 230 to nearly 2,000 .

The interests of the factory (ingenio) and the farmers (cañeros) are not indissolubly connected. Their respective parts in the final product of the sugar industry are not invariable. The increase in the number of factories means an increase in the number of canebuyers, and so tends to raise the price. During the years antecedent to 1895 the refineries improved their machinery, and their productive capacity increased faster than the cultivated acreage. The price of the cane then rose to about twenty piastres a ton. As this figure is far above the net cost, the refineries endeavoured to profit themselves by the advantages that accrued to the cañeros, and they bought land for cultivation. It is to this period that the big concerns of Cruz Alta belong. Afterwards the production of cane increased, and nearly met the demands of the refineries, so that their competition relaxed. They ceased to buy land, and the price of cane was lowered.

The refineries now deal with cane which they grow themselves, with paid workers of their own; with cane that they buy at a reduced price from tenants (colonos), who grow it on their own estates; and with cane sold them by cañeros who own their own fields. The range of the country absorbed by each refinery is often very extensive. The Sugar Congress of I894 estimated that half the cane-harvest was transported by rail, and that freight from one canton to another in the sugar district brought the railways more than a third of what they got for conveying sugar from Tucumán to the coast. Each railway company tries to keep along its own line the cane it carries to the refineries, so that the transport of the sugar when it is made will fall to itself. Thus the cane-market is 
divided into two separate compartments, with very little exchange between them. The first comprises the zone that depends on the Central Argentine and the State Railway; the second is the zone of the Central Córdoba and the old local line bought by the Central Córdoba.

Certain parts, such as Cruz Alta and the district round the town, have too many works in proportion to their production of cane, and they are centres of import. The price of the cane is always higher here than in the agricultural districts. Each works has its customers. At the stations it instals weighing machines for receiving and weighing the cane. It is only the more important cañeros who have the privilege of selling by the truck-load, or selling to distant works. The small growers are compelled to deal with the local refinery. They sell it their canes direct, or, sometimes, through agents and dealers. In the days when the works were competing for cane it became the custom to sign the purchase-contracts as early as possible; sometimes at the beginning of October, as soon as the harvest of the year is over. In order to make sure of the loyalty of the cañero the manufacturers advance money to him, in proportion to their difficulty in getting cane.

Cañeros and mill-owners have had to work together to settle the problem of labour. There was not enough at hand, and it had to be recruited elsewhere. Agents were sent all round-to Catamarca and Santiago del Estero, and even to the province of Córdoba-to collect and bring gangs of workers. They were a mixed, unsteady, undisciplined lot. The owners of the works advanced them money in order to keep them, and then, fearing to lose the money advanced, would not dismiss them for laziness and irregularities. These troubles are not felt as much now as they were at the time when the industry was expanding. The population of immigrant workers has settled down and taken 


\section{THE SUGAR-CANE HARVEST}

root. Besides creoles it includes a small number of Italians and Spaniards; but while the creoles have been definitely incorporated in the sugar industry, the European immigrants use their savings to buy a bit of land and take to farming.

In normal times Tucumán has all the labour it requires, but the harvest always compels it to seek help in other provinces. In May and June the agents, well supplied with money, set out for the Salado, the districts round the Sierra d'Ancasti, etc. The temporary attraction of Tucumán at this season is felt over a considerable distance. At Santa Maria, on the far side of Mount Aconcagua, 600 people-men, women, and children-emigrate for five months, and live on the cane-fields. The merchants of Santa Maria make them advances, in the name of the refiners, to the amount of about sixty piastres per worker. Further north the Tucumán enganchadores come into collision with those from Salta and Campo Santo, and they divide the available labour between them. Some of the temporary immigrants settle down permanently every year, and swell the normal population of the sugar industry.

Outside the Tucumán district an unfortunate attempt was made to plant the sugar industry at Santiago del Estero, and large works were constructed. But the frost is severe there. For some years they tried to keep the Santiago works going with cane brought from Tucumán, but the freight was too heavy, and the works had to be abandoned, or else dismantled and set up elsewhere. The valley of the Rio Grande, from Jujuy to 200 miles north of Tucumán, in the subAndean depression between the Sierra de Zenta and the Lumbrera, has, on the other hand, suitable conditions for the cultivation of the cane. Frost is rare. The climate is warmer than at Tucumán, the canes ripen more quickly, and the average return is higher. The water-supply also is good. There have long been 
plantations in this region. Their first market was the region of the tableland and the valleys, where they chiefly sold brandy: a traffic of long standing, which one always finds round the cold districts of the Andes, from Colombia to the north of Argentina. The modern refineries of Ledesma and San Pedro took the place of the primitive mills as soon as the railway approached Jujuy, and even before it entered the valley of the Rio Grande. They then sent their sugar by waggon in November and December, between the close of the sugar season and the commencement of the rains, which spoil the roads.

The sugar district of Jujuy now has a very different economic and social organization from that of Tucumán. Here there are no farmer-proprietors. Each centre is a large estate, in the midst of the forest, where the workers are lodged and fed by the works that employs them. The contractors who clear the ground for them are obliged by the terms of their contract to import their workers directly from the south, so that they will not take any away from the farming. There is no available labour, no free market, on the spot. Since the completion of the Quebrada de Humahuaca line, however, there has been a good deal of immigration, to settle or temporarily, of the mountaineers of the tableland. The sphere of influence of San Pedro now extends as far as Bolivia. For the harvest, which, like that of Tucumán, requires a good deal of additional manual labour, the works look to the wild Indians of the Chaco. This curious stream of seasonal migration, which the sugar campaign of Jujuy provokes every winter outside the zone of white colonization, is of very old date, going back more than sixty years. Belmar notices it about the middle of the nineteenth century. The recruiting agents of San Pedro and Ledesma set out from Embarcación, where the railway ends, and enter the Chaco, from which each of them brings a troop of some hundreds of natives between March and June. 
The number of these temporary immigrants seems to be about 6,000. The Chiriguanos of the north leave their families on the Chaco, and the men come alone. The Matacos immigrate in whole tribes. They camp in huts like those of their own villages, under the shelter of the works, and are paid in maize, meat, and cigars. In October, when the algarroba flowers and makes them dream of their own country, they receive the remainder of their pay in money, and spend it in brandy, clothing, knives, and firearms.

The history of Mendoza resembles that of Tucumán in many ways. In the province of Cuyo, as at Tucumán, urban life has been precocious. In the middle of the eighteenth century Mendoza and San Juan exported wines, dried fruit (pasas and orejones), and flour to the coast and to Paraguay. Part of the so-called "Chilean flour" consumed on the Pampa, really came from Jachal and Mendoza. This trade ceased in the nineteenth century, but San Juan and Mendoza found another source of wealth in fattening cattle and sending them to Chile. Belmar, in 1856 , estimates the extent of the lucerne farms of Cuyo to have been 150,000 cuadres (440,000 acres). ${ }^{\mathrm{r}}$ As at Tucumán, the present period is characterized by a rapid expansion of cultivation and a rapid growth of population. But, whereas at Tucumán the neighbouring provinces have provided the whole of the manual labour required, and the actual population is essentially creole, at Mendoza there has been a larger number of foreign immigrants. In I9I4, foreigners were 3 Io per I,000 of the entire population of Mendoza: a larger proportion than for the whole country. The immigrants going straight to Mendoza from the ports numbered I2,000 in I9II, and I5,000 in I9I2; almost as much as for the province of Santa Fé, and more than for the province of Córdoba. Thus Mendoza plays a part of its own in the charm

I A few convoys of cattle still use the Uspallata road, especially over the Espinacito pass in the Cordillera de San Juan. 
which Argentina has for the imagination of Europe. When we examine a chart of the population of South America, we notice that the oases of Cuyo contain the only important groups of European population at any distance from the coast.

The prosperity of Mendoza to-day depends upon the cultivation of the vine, just as that of Tucumán depends upon sugar. The cultivation of the vine is possible in the greater part of Argentina. In the early days of colonization there were vineyards as far as the Paraguay. They still flourish at Concordia on the Uruguay and at San Nicolas on the lower Paraná. But the wet summers of the eastern provinces are not suitable for them. The climate for them improves as one goes westward, and there is less rain. The dry zone of eastern Argentina is the special field of the vine. There it has spread over nearly twenty degrees of latitude, and it depends, like other cultivation, upon irrigation. In the Andean valleys of the north-west it rises to a height of 7,500 feet. South of Mendoza the higher limit of the vine sinks rapidly, and there are no vineyards in the mountainous district itself. On the other hand, its range increases; in the east it spreads as far as the Atlantic coast, in the valley of the Rio Negro.

The former centres of viticulture in the north-west, in the oases of the costas of La Rioja, Catamarca, and Salta, have scarcely been affected by the advance; and, in any case, their extent is very limited. The vine-district of the Rio Negro is only in process of creation, and its output is still small. Thus the area of production on a large scale is limited to the three oases of San Juan, Mendoza, and San Rafaël, which in I9I3 yielded 4,750,000 hectolitres, out of the total Argentine production of $5,000,000$ hectolitres. These three centres differ from each other to-day rather in their economic development than in their physical conditions. At San Juan, the transformation of the earlier methods of production and the traditional creole industries is 
only now taking place. At Mendoza it is quite finished. The San Rafaël centre, on the other hand, is of recent origin; it was created on the site of a fortress which guarded the Indian frontier until I880. Cultivated areas have appeared on virgin soil, in the midst of the desert. These different circumstances account for diversities which, though they will disappear in the course of time, are still obvious to the traveller. The general scene is the same everywhere. Arid and desolate mountains close the horizon in the west; at their feet spreads the immense alluvial deposit on which the vineyards, surrounded by rows of poplars, grow wherever water is to be found.

There are so few gaps in the lower slopes of the Cordillera that the available water is gathered at a small number of points. The Rio San Juan alone drains a belt of the Cordillera at least I 40 miles broad. Each of the two oases, Mendoza and San Rafaël, has two streams of water to feed it. The Mendoza and the Tunuyan at Mendoza, and the Diamante and the Atuel at San Rafaël, approach each other, when they leave the mountains, so closely that the estates they water blend into a continuous area. Then, however, instead of uniting, they diverge and are lost, separately, in the plain. These streams have less fall than the thinner torrents of the oases of the north-west, and the average inclination of the dejection-cones which bear the vineyards is slight. The upper slopes of the cone, where thin beds of clay lie upon shingle, give clear wines of excellent aroma. Hence, in the Mendoza district, the vineyards of Lujan and, further down, of Godoy Cruz, Guaymallen, and Maipu produce choice brands. On the plain, to the east of Mendoza, at San Martin and Junin, the harvest is larger, but the wine is rough, and one can often taste the saltpetre of the clayey soil. There is the same difference between the upper and lower district at San Juan and San Rafaël. 
The oases of San Juan and San Rafaël spread evenly over the most suitable parts of the alluvial talus, but the oasis of Mendoza has a peculiar shape which can only be explained by historical causes. The cultivated belt is a narrow strip along the Tunuyan, for more than sixty miles, as far as the heart of the plain, out of sight of the Cordillera. It is one instance, out of a thousand, of the influence of traffic on colonization, As a matter of fact, the road from Mendoza to the coast, by which the cattle convoys of San Luis went to the invernadas, passes along the Tunuyan. The estates grew up by the side of it. The villages of Santa Rosa, Las Catitas, and $\mathrm{La} \mathrm{Paz}$, which mark the various stages of it, are all of ancient origin. Strangers are rarely found there. One still sees in them very old houses, built before the railway was made, dating from the days of the carril or waggon-road. The importance of this line of water across the desert is clearly seen on the Woodbine Parish map.

The use of irrigation in this district raised different technical problems from those of the north-western provinces. In this latitude the torrents of the Andes are formidable when the snows meet, at the beginning of summer. The flood is all the greater and more sudden as the heat is late. From all the ravines of the mountains the muddy waters then converge toward the valley. The flood scours the bed of the river, erodes its banks, and threatens to find a way amongst the estates. Even the towns of Mendoza and San Juan have more than once been in danger. The fear of diverting the flood and of bringing it upon themselves compelled them to be content with raising only light and frail dams in the path of the torrent. At San Juan they used, for a long time, the waters of the Arroyo del Eestero, a small brook fed by infiltration from the Valle de Zenda, and it was some time before they ventured to draw upon the river itself.

Another problem, which the smaller oases of the 


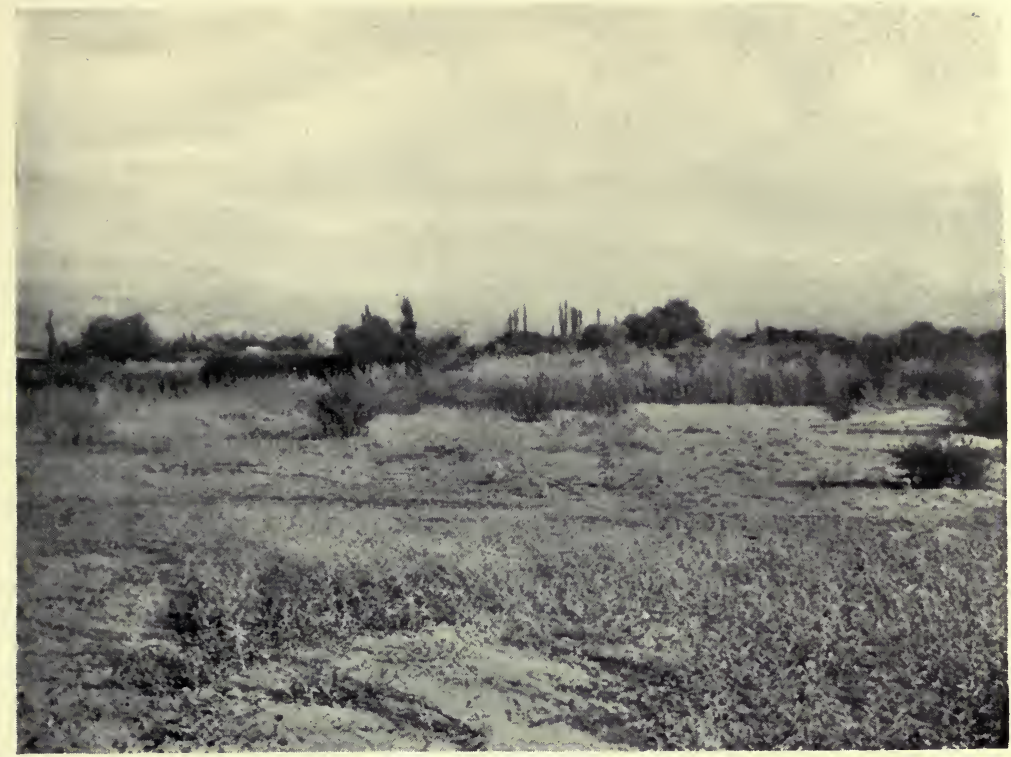

THE OASIS DEL RINCON, BELOW SAUJIL (ANDALGALA LINE, PROVINCE OF CATAMARCA).

The dejection-cone, at the foot of which is the very small oasis, is seen resting against the Sierra d'Ambato. Photograph by the Author.

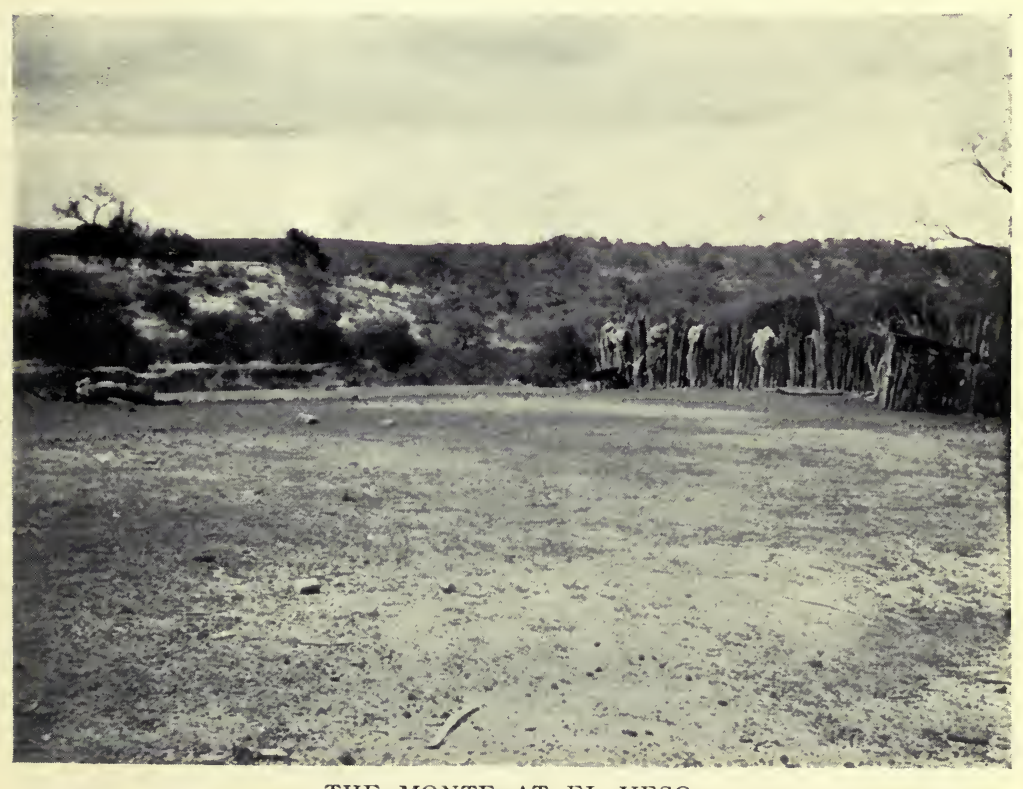

THE MONTE AT EL YESO.

Zone of clay hills at the foot of the Sierra de San Antonio, at the edge of the Chaco. Corral (catile park) made from tree-trunks. Photograph by the Author. 

orth-west hardly know-the problem of drainage-is of paramount importance at San Juan and Mendoza, as far as a large part of the irrigated surface is concerned. The water infiltrating into the soil forms a subterranean sheet which approaches more or less to the surface according to the topography. It comes to the surface at the foot of the cone, where the slope dininishes and the cone gradually passes into the plain. Hence the cone has, at its base, a belt of marshes (ciénagas), and sometimes a line of good springs (barbollon). At San Juan, if you move far enough away to get a comprehensive view of the whole of the estates, you see that they occupy the middle belt, half-way down the cone, the top of which is composed of coarse shingle, while the bottom is too wet. The advance of the plots upward and the steadily increasing use of the available water tends to raise the level of the underground sheet and enlarge the area of marsh.

There is a fine black soil, very fertile when it is drained, and no irrigation is needed; as it is possible, according to the depth of the drainage-trenches, to regulate the level of the underground water so as to make it reach and feed the roots. The draining of the marshes, again, opens up a field for the further expansion of the estates, especially at San Juan, where it has scarcely begun. Moreover, the water that is obtained by draining the marshes enables them to create new irrigated estates further on. At Mendoza there is already a considerable area irrigated by drainage-canals (desagüe).

The level of the water in the marshes sinks in the summer and rises in winter, at the time when the irrigation of the upper districts is suspended or greatly reduced, and when the surplus of the acequias, which the fields no longer take, flows or infiltrates downward in any way that it can. Thus, contrary to the torrent itself, it is in winter that the drainage-canals are at 
their fullest. At Barriales (Mendoza), and on the lower course of the Zanjon canal, thousands of acres, watered by the drainage-canals and exposed to drought in the summer, have the right to take water from the river or the canal during the three summer months, from November to January. During the remainder of the year they are restricted to the use of the drainagecanals. This sort of concession seems to provide a means of using the surplus of the river during the summer.

With this exception there are no temporary rights limited to the high-water season and enabling them to raise quick crops, that ripen in a few months, round the area of perennials. At least, the expansion of the estates and the wish to use the full water-supply have led to the creation of eventual rights, besides the definitive rights. They do not come into play, theoretically, until the definitive rights have had their full supply, and then only in a fixed order. They are subordinated to the ordinary rights, and the market value of land with eventual water-rights is much lower than that of land with definitive rights. ${ }^{\text {I }}$ At San Rafaël, where colonization preceded the systematic inventory of the natural resources, the concession of eventual water-rights was a means of facilitating the development of estates; though they were very badly informed as to the surplus of the Atuel and the Diamante and the area that the new land might cover.

In practice, the co-existence of eventual and definitive rights presents many difficulties, and more than one pretext for fraud. Somtimes the owners of eventual rights have access to the river higher up than the older intakes, which ought to be served first. A whole group of canals feeding land with eventual rights is

x There are at present in the Mendoza province 275,000 hectares with a definitive right, and 303,000 with an eventual right. The concessions fed by the Diamante and the Atuel at San Rafaël, which amount to 120,000 hectares with a definitive right and 150,000 with an eventual right, are not yet entirely developed. 
in this way grafted upon the Tunuyan above $\mathrm{La} \mathrm{Paz}$, the rights of which are definitive and ancient.

At Mendoza and San Juan the water-rights, codified in provincial laws which date, like the dams, from the end of the nineteenth century, are very different from the water-rights which hold in the Andean provinces of the north-west. The variety of the physical conditions is reflected in the institutions. Here water is not an object of private ownership independently of the soil. The concession of water is assigned to a definite estate, and it is formulated in superficial measurements. The law fixes the volume of water that goes with each unit of surface. If the output of the river is not large enough to provide the volume stated in the law to the whole of the irrigated district, all the lands with definitive rights receive at least an equal amount, and the available water is shared by the canals in proportion to the extent of the surface they irrigate.

No law could secure for the farmers of Cuyo, even those with definitive rights, a constant supply of water, or save them from suffering in common from the variation in the volume of the torrents, and it was not even possible to guarantee them water in any permanent fashion. The turno is used everywhere when the water is low. Lower down, where the drought lasts nearly the whole year, the turno is the standing rule. At La $\mathrm{Paz}$, on the fringe of the irrigated area, it has to be applied rigorously. The turn of each owner comes every eight, ten, or twelve days. In normal times he receives the suerte de agua; that is to say, the output of a sluice of a fixed size during a half-hour for each hectare (a little over two acres) of land. But if the river runs low, it becomes impossible to supply several neighbours simultaneously, and, in order to avoid making the interval between supplies too long, the duration of the suerte de agua is reduced by half or three-quarters. 
The oases of Cuyo are like the small oases of the north-west as regards the function of those who are engaged in the administration of irrigation. The waterlaws give the provincial functionaries general directions. Below them, however, to arrange the distribution of the water and the upkeep of the canals in detail, they have allowed to survive, and have merely regulated, certain primitive democratic organisms. At San Juan the superintendence of the irrigation is entrusted to elected municipal councils and the governor of the department. At Mendoza, the owners appoint a council of three delegates and an inspector for each canal, and these settle the annual budget of the canal, submit it to the provincial authorities, receive the taxes, carry out the necessary repairs, and so on. The great subdivision of property and the large number of electors make these little republics very lively; and they are very jealous of their autonomy. ${ }^{x}$

Even within the narrow limits of the Cuyo district the climatological conditions, which control the growth of the vine, are not everywhere the same. The opening of the vineyards varies by several weeks, according to the locality. ${ }^{2}$ The northern slope of the cone, exposed to the sun and protected from the southern winds, is more precocious. Some districts, poorly sheltered from the southern winds, and very liable to have late frost, have not been planted with vines (district of the Tucuyan below San Carlos, to the south of Mendoza). Everywhere the dryness of the atmosphere causes the ripe grapes to remain long on the vine, so that the harvest may last two months or more

x There are more than 6,000 owners at San Juan to 9r,ooo hectares, and more than 9,000 at Mendoza (zone of the rivers Mendoza and Tunuyan) to 130,000 hectares (statistics compiled in 1899).

2 The difference is much greater at a distance from the Cuyo province. Catamarca, which specializes in the production of grapes for the table, is invaded by buyers from Buenos Aires, and begins to send grapes in December, two full months before the harvest begins in Mendoza. 
without any harm. It thus requires a relatively small supplement of manual labour, and does not necessitate seasonal migrations. The length of the harvest, moreover, facilitates the trade in grapes, which is one of the special features of the Argentine vine-industry.

The climate is not so suitable for making wine as it is for growing vines. The temperature is high at the time of the harvest, and it retards fermentation in the cellars. The grapes have too much sugar and too little acid for the transformation of the must to proceed of itself. Hence it is necessary to have an expensive equipment, improved cellars, and skilled workers. This industrial organization is beyond the reach of the small cultivators. The cultivation of the vine and the making of wine are, therefore, not always associated. They are taken up by two different classes of the population. Tucumán has its cañeros and factories, and Mendoza, by a division of labour which seems to the European visitor as strange as the climate which partly explains it, has its vine-growers (viñateros) and its manufactures (bodegueros). ${ }^{\mathrm{I}}$

Each of these two classes has had its share in the common work. The viñatores have created the vineyard. The creole vine, imported into Peru from the Canaries and spreading over the whole of the southern Andes, yields great quantities of a sugary, but rough fruit, which does not lend itself to imitating the wines of Europe. At Mendoza it has almost entirely disappeared, though it survives at San Juan. It is grown on trellis-work, wooden frames resting on forked branches of algarroba; though sometimes the strong stems rise without support to a height of about six feet and are crowned with shoots and leaves. The new vine has been grown from French cuttings. While

- While the cultivation of the cane has, for the most part, become dependent upon the sugar industry, which represents large capital, wine-making is, on the contrary, usually regarded as merely an annex of wine-growing. 
the creole vines look like orchards, the French vines are grown in rows of iron wire.

The plantations were first made by creole workmen, who were paid by the day. Afterwards, as immigration from Europe increased, long-term contracts came into vogue, in virtue of which the colonist received the bare land and undertook to have it planted with vines at the end of three, four, or five years. The owner supplied the material, and at the end of the contract the colonist received a few centavos for each vine, or sold the whole or part of the first harvest. On account of these contracts there were always a great many foreigners in the districts where vineyards were in course of formation. The proportion is now less at Mendoza than at San Rafaël, where colonization is more recent. Whenever they could, the owners left to the colonists, not only the business of planting the vines, but the upkeep of adult vineyards. In those cases the colonist receives a fixed sum per hectare (Ioo piastres, for instance), and has to dig, prune, irrigate, etc. A large number of these agricultural workers and small contractors have saved a small capital, and purchased land of their own. This they have planted, and they thus form a new class of working owners.

While the vinatores were multiplying vineyards, the bodegueros were transforming the methods of making wine. The weakness of imperfectly fermented wines, which turn sour and evaporate quickly, was all the worse for the growers of the colonial period because transport was slow, and there was no protection against the sun, which cooked the algarroba casks or the leather bottles on the backs of the mules. The vineyardowners often preferred to distil their wine and export brandy, flavoured with aniseed, to the Andean tablelands or the coast. The climate and the risks of transport had brought into existence an astonishing variety of methods of treating the must. Sometimes it was concentrated by boiling until it became a thick syrup 
(arrope), something like, apparently, the thick wines of the Mediterranean in former times. At other times the must was cooked without thickening it, to prevent immediate fermentation, as is done with the chicha in Chile to-day; or sour wines were mixed with boiled must and ashes of the shoots, which masked the acidity.

These traditions are now lost, but it is curious to see the bodegueros still endeavouring to meet the taste of the creole population of the north-west, which has retained the preference for sweet and fruity wines. San Juan, which caters to these customers, manufactures mistelas-fresh boiled must with an addition of alcohol - which are mixed with mature wines in order the imitate the imperfect fermentation of earlier days. Perhaps there is no part of the world where the art of winemaking has been pushed so far as in the bodegas of Mendoza. The correction of the must, and the analysis and treatment of diseased wines, follow the most modern of methods. The bodegas produce a very steady wine, which is guaranteed by their trade marks. The wine of the Mendoza type, which they endeavour to produce, is a strong red wine, of heavy colour, with twelve or thirteen per cent. of alcohol. It may euphemistically be called a blended wine, but is in reality diluted wine. Argentina does not produce very light wines, and has no use for diluted wine.

The number of wine-making cellars in I9I3 was 997 at Mendoza and 336 at San Juan. But they differ very much from each other in size. Most of them have only a small equipment and modest capital. Some, on the other hand, are large enterprizes which could produce enough to supply a city: vast constructions of brick or adobe, with light roofs as a precaution against earthquakes.

The owners of the cellars almost always have their own vineyards, but they also buy the harvests of cultivators who have not cellars. In I908 it was calculated that 140,000 tons of grapes were sent to the press 
by the owners and I75,000 tons bought by the bodegueros. ${ }^{\mathrm{I}}$

The conflicts of the interests of the vinateros and the bodegueros are the very woof of life at Mendoza. The price of grapes is infinitely more variable than that of wine, and the vinatero who has no cellar is at the mercy of the bodeguero. If he does not want to see his harvest go to waste, he has to accept unconditionally the price that is offered him. The bodeguero has, moreover, the advantage of disposing of the grapes grown on his own estates. If the circumstances do not encourage him to produce all he can, he sends to the press merely his own harvest and will not buy any other. Thus the whole burden of commercial crises falls upon the vineyard with no cellar.

The prices paid for the grapes differ a little for different parts of the vineyard, but the variation is more due to the number of bodegas in the district and their capacity than to the quality of the grapes. Transport of the grapes to a great distance is very expensive. In exceptional times grapes have been brought from San Rafaël to the Mendoza cellars, but each bodega gets its supply as far as possible from its own district. At San Juan the capacity of the cellars is proportionately less than at Mendoza, and the bodegueros have imposed very hard conditions on the growers. The price fixed in the purchase-contract does not of itself give a complete idea of the benefits which the bodeguero enjoys. The grapes are purchased by weight, but the bodeguero reserves the right to say at what date they are to be delivered. He begins to harvest his own vines when the fruit is scarcely ripe, but he puts back the harvesting of the grapes he buys as far as possible, even to April or May. These grapes exposed on the plant to the heat of the sun, become overripe; they gain in sugar and lose in weight. They

× More recent statistics are not to hand. The proportion differs a little every year according to the prices of wine and grapes. 
make vines with a higher percentage of alcohol, and with these he can correct the lighter wines made during the preceding weeks. Finally, the bodeguero does not advance money to the vinatero, as the manufacturer does to the cañero in the sugar industry.

The only safeguard of the vine-growers is the lack of understanding between the bodegueros and the competition between them. Although there are conventions amongst the bodegueros which lay down officially, before the vintage, the basis of all transactions, they are not respected except in so far as they serve a man's interest. If it is expected that the wine will easily be sold, and that grapes will be short, buyers are abundant, and contracts are signed before the fruit appears. It is a sort of gamble, as in the case of wheat and cotton. Bulls and bears struggle for the market. If the bulls win, the viñateros grow rich.I

When we compare the diagrams which show the production of wine and sugar in Argentina during the last thirty years, we see that they clearly illustrate the condition of dependence of the vineyard industry and the sugar industry as regrads the home market. The prosperity of the region of the Pampas, especially during the years before I9I4, is reflected at Mendoza and Tucumán. The expansive movement of the estates is similarly bound up with the construction of railways to connect them with the coast. Industry, on a large scale, began at Tucumán in 1876 : that is to say, at the opening of the Central Córdoba line. The area planted with cane rose from 2,200 hectares in 1876 to I4,800 in I886. The production of sugar was trebled

I Besides the causes of a geographical nature which I have indicated, the separation of cultivation from wine-making has other economic grounds, but they do not fall within the range of this book. The large bodega is better situated than the small cultivator for organizing the sale of his wines on the distant market of Buenos Aires. Also, the bodegueros alone are able to meet the competition of Buenos Aires merchants who imfort European wines and make adulterated wines. 
in four years, from $I 876$ to $I 880$. But the Central Córdoba was a narrow-gauge line, expensive to use and necessitating a transfer of goods at Córdoba. In I89I the broad-gauge line from Buenos Aires to Rosario was extended to Tucumán; and in 1892 the narrowgauge line from Rosario to Santa Fé, San Cristobal, and Tucumán was also brought into use. The following years were marked by rapid advances of the sugar industry. From I89I to I895 the area planted with canes rose from $I 4,200$ to 40,700 hectares, and the manufacture of sugar from $3 I, 000$ to $I 35,000$ tons. At Mendoza; also, the development of the vineyards dates from the completion of the San Luis Railway in I885. Plantations were at once started, and three years later they came into touch. In I887, the railway carried 27,000 hectolitres of wine from Mendoza to the coast; in I890-9I it carried 268,000 hectolitres. Production had increased tenfold in that short space of time.

As the home-production of wine and sugar increased, the imports from abroad fell. As early as I885 Tucumán was able to meet the home demand for raw sugar, and refined only was imported. In I888, a refinery was erected at Rosario to deal with Argentine sugar which came by rail, and foreign sugar which came up the river. Import ceased at this date, or there have since only been occasional years of import, to meet a scarcity. The imports of ordinary foreign wines continued to increase until I890 (800,000 hectolitres), or as long as the wine produced at Mendoza did not suffice to meet the demand. They have steadily declined since that date (350,000 hectolitres in I9I3), and are now only seven per cent. of the national production. We should add that, even in regard to ordinary wines, the Mendoza and the imported wine are not strictly comparable, that the competition between them is not simply a matter of price, and that some customers continue to prefer foreign wine. 


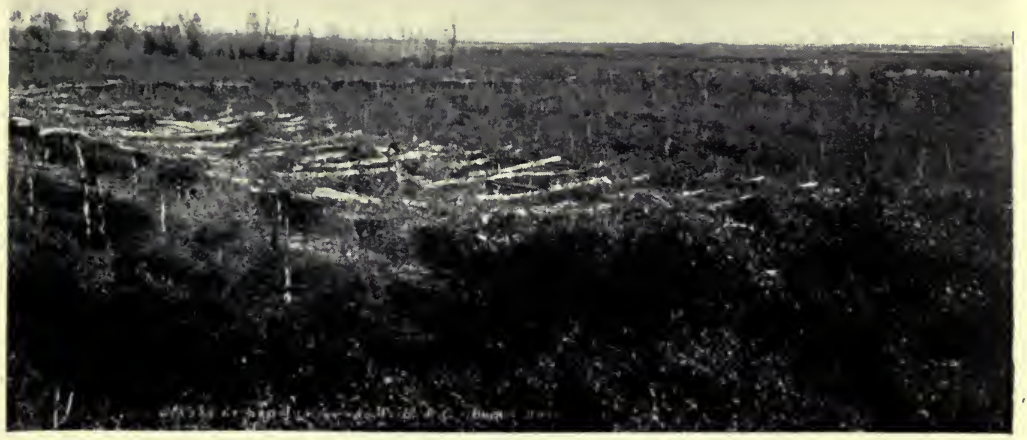

A VINEYARD AT SAN JUAN.

Trellissed creole vines.

Photograph by Boote, Buenos Aires.

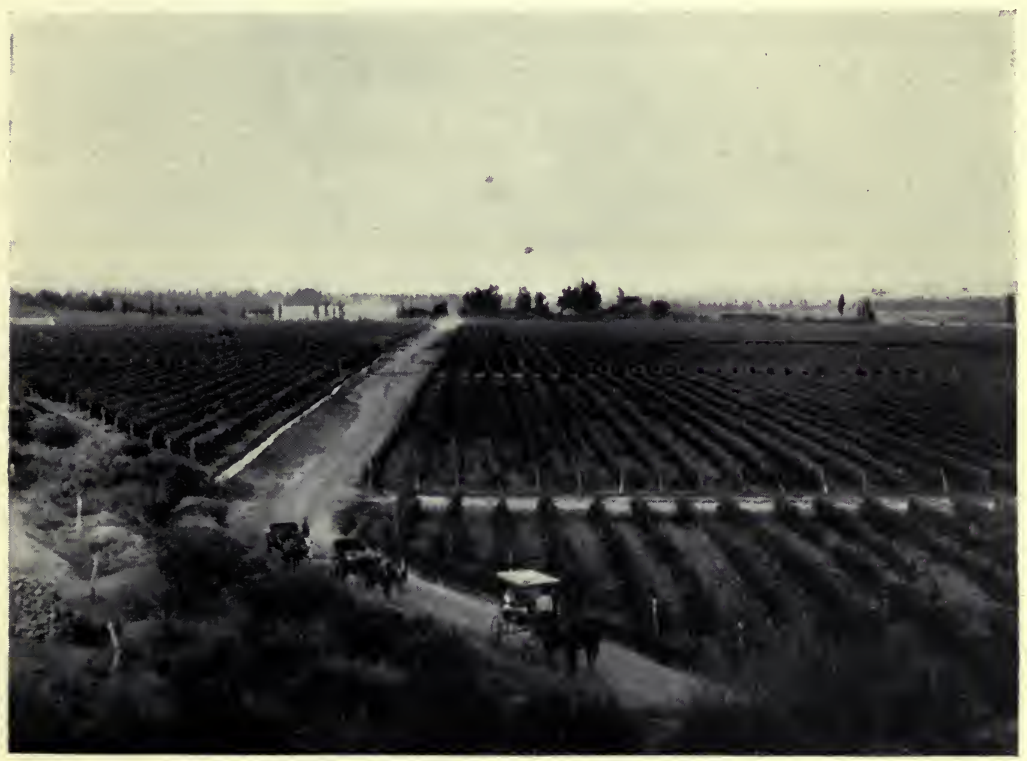

A VINEYARD AT MENDOZA.

French vines on wire. An irrigation-trench along the path. In the foreground (left) a winecellar (bodega).

Plate ViII.

Photograph by Soc. Fotografica de Aficionados, Buenos Aires.

To face p. 92 . 



\section{PROTECTIONIST TARIFFS}

The elimination of foreign wines and sugar and the development of Mendoza and Tucumán were facilitated by a Protectionist tariff. The details of this are very curious, as they had to be adjusted to the natural conditions. The need of protection is chiefly due to the distance of the market from the productive centres. Mendoza is 650 miles from Buenos Aires, Tucumán more than 750 miles. Freightage on the railways is dear. It is thirty-five piastres a ton for wine between Mendoza and Buenos Aires, or nearly double the normal maritime freight for the European wines sent from Bordeaux or Genoa. The charge for sugar is about thirty piastres a ton between Tucumán and Buenos Aires. Thus the cost of transport is nearly one sixth the entire cost of production. In spite of this common burden, the need of protection is not at all the same in Mendoza and Tucumán. The climate of Mendoza is excellent for the vine. The dryness of the atmosphere keeps down cryptogamic diseases, and the risks of cultivation are slight. The crop is abundant, the frosts late, and not serious. Hail is frequent, it is true, at the mouths of the Cordillera valleys, but it is never general ; it affects only a small part of the harvest. The curve of production is very regular. It rises every year very gradually, and in proportion to the increase of the cultivated area. As a result of all this, the wine market has a stability which the vine-growing countries of Europe, with their less reliable climate, do not enjoy. The protective tariff, therefore, remains fixed. The duty on foreign wines in the cask-eight centimes (gold) per litre-has not been altered since the introduction into Argentina of the wine-industry on a large scale. $x$

- Mendoza is further protected by law against fraud. This legislation is partly national and partly provincial. The national law, which takes into account the interests of the merchants of Buenos Aires, permits the manufacture of artificial wines. The provincial law, in the special interests of the productive districts, is more stringent. It prohibits the manufacture of artificial wines. It also 
The curve of sugar-production is just as irregular as that of wine-production is regular. From one year to another the output may vary by as much as roo per cent., and the changes cannot be predicted : I47,000 tons in I9I2, 335,000 tons in I9I4, I50,000 tons in I9I5. The reason is that the sugar output depends upon the season. Canes which have been touched by frost go sour and ferment in the ground. They have to be milled quickly, and the harvest must not be prolonged. Even in good years the costly equipment of the works is active during only three months (July to September, but at Jujuy, July to October).

This irregularity of production, which makes protection inevitable, also complicates it infinitely in practice. Sometimes the harvest is not large enough to meet home demands, and imports have to be permitted. Sometimes production is far beyond the home demand, and the sugar-manufacturers have to export the surplus so as to prevent a slump in prices on the overloaded home market. In order to meet these very different situations, the protecting tariff has had to be repeatedly modified and complicated. But it is impossible for us to give the history of it in detail here. The duties on foreign sugar were fixed, in successive instalments, between I883 and I89I; and special protective measures were taken in the interest of the refiners in I888. Over-production appeared for the first time in I895. Export at a loss, to relieve the home market, was at first organized by an association of the producers themselves (in 1896). But in 1897 the Government developed it by putting a premium on export. The export period lasted from I897 to I904. The law of I9I2, which gives its latest form to the Protectionist regime, gives the Government fixes the minimum percentage of alcohol, and prevents the dispatch from Mendoza to Buenos Aires of alcoholic wines to mix with must. Finally, it defends the viñatero against the bodeguero by fixing the quantity of grapes to be used in making a hectolitre of wine and so prevents fraud at the bodega. 


\section{THE TROUBLES OF TUCUMÁN 95}

the right to suspend for a time the duties on imports and allow foreign sugar to come in. As at Mendoza, the provincial Government intervenes as well as the national. The alternation of bad and exceptionally good harvests leads to the appearance of all sorts of unforeseen laws, modifying the bases of taxation, regulating production in the works, and restricting the acreage of cultivation. ${ }^{\text {I }}$ Thus Tucumán has lived in an atmosphere of storm and uncertainty and unceasing discussion, of discouragement and insecurity; the price of its geographical position at the extreme limit of the area in which cane can be grown.

Especially during the crisis of $1902-3$. 


\section{THE EXPLOITATION OF THE FORESTS}

Manual labour on the obrajes-The land of the bañados and the agricultural cantons of Corrientes-The timber-yards of the Chaco and the tannic-acid works of the Parana-The exploitation of the maté-The forestry industry and colonization.

From the Andes of Tucuman and Salta to the banks of the upper Paraná in the province of Misiones the north of Argentina is now a vast timber-yard for the exploitation of the forests. It resounds everywhere with the axe. This exploitation of the forest is of early origin on the river; in the eighteenth century Buenos Aires was supplied with wood from the Paraná. In the western Chaco the difficulty of transport by land retarded the development of the forestry industry. The only market for the timber of Tucumán was the Andean region. It was not sent to Mendoza after the beginning of the nineteenth century, when the willow was acclimatized in the oases of Cuyo. Below Rosas the wood of the quebracho was at first taken in waggons from Santiago to Buenos Aires, but this traffic ceased when the river-route was reopened, and we do not find it resumed until recent times, when railways were constructed.

The outer fringe of the forest and the scrub where the industry has had to find labour, is inhabited by a very sparse pastoral population. There are, however, besides the thinly populated districts of the farms, certain busy hives which lend animation to the scrub. These over-populated cantons are districts of cultivation by 
bañados, or the cultivation of flood-lands. There is constant intercourse between these ancient centres of creole life and the timber-yards of the forest. The forestry industry recruits its workers there, on temporary contracts. The wages paid are brought back to these centres and spent there. They help to maintain social groups of an archaic type, which the meagreness of their production would otherwise doom to extinction.

The bañados are scattered over the range of all the sierras within the limits reached by the torrents from the mountains before they are lost. They also stretch along the two rivers that are considerable enough to cross the scrub, the Salado and the Dulce. The course of the Bermejo, where the natural conditions are much the same, lies outside the sphere of primitive creole colonization. The tilled lands are not continuous on the Salado or the Dulce. There are no bañados wherever the bed of the river is enclosed by high banks which prevent flooding. The course of the Salado threads together, in the manner of a rosary, three main groups of bañados below $26^{\circ} \mathrm{S}$. lat., (Matoque and Boqueron) between $27^{\circ}$ and $28^{\circ} \mathrm{S}$. lat. (Brea), and between $28^{\circ}$ and $29^{\circ} \mathrm{S}$. lat. (Le Bracho and Navicha). But the classic country of the bañados, where they cover the widest extent and sustain the most considerable body of population, is the interior delta of the Rio Dulce below Santiago del Estero, in the departments of Loreto, Atamisqui, and Salavina.

Santiago is situated almost at the top of it. In its upper part the Rio Dulce is enclosed between high clay cliffs (department of the Rio Hondo). Below Santiago the river seems to run to the top of a sort of flattened alluvial cone, over which it wanders. Instances of the migration of rivers during the historical period are plentiful in the north of the Argentine plain. The scrub is scored east of the Salado with a network of dry beds, the edges of which gradually disappear as the 
vegetation extends over them. But there is no other part where the erratic nature of the waters is so marked, the vagabondage so considerable, as in this section of the basin of the Rio Dulce. The small towns of Atamisqui and Salavina, which lived on the waters of the Dulce, were suddenly ruined in 1825 , when the river, in consequence of a particularly violent flood, turned away to the south and lost itself in the Salinas Grandes. A canal was dug in 1897 to irrigate the district of Loreto, on the left bank of the Dulce, but the entrance was badly protected, and the flood of I90I swept into it, and, guided by it, reached the bed it had abandoned a century before, going south-eastward toward Atamisqui. That town and Salavina recovered their prosperity, while it was necessary to abandon the farms on the Rio des Salines, which now has water only during high floods. Actual beds, old beds that are always ready to serve again, and traces of canals changed and cut by the stream, form a great network in the midst of the plain ; and the flood rolls to one side or the other according to the road open to it, and the facility with which the various elements of the network lend themselves to the passage of the water. Such is the land of the bañados.

You enter it to-day at Loreto station, where the line from Santiago to Frias approaches within a few miles of it. This station is erected in the midst of the arid monte, and owes its existence to the neighbouring bañados. Turning eastward from the railway, as soon as one has crossed the broad, sandy bed of the Rio des Salines, one finds oneself in the heart of the bañados farms. The road passes between hedges (cercas), over the top of which one sees the green of the wheat and lucerne. The plots are very small : gardens rather than fields. In clearing the ground they have preserved the best-situated trees, and the light foliage gives a useful shade to the crops. The crown of the algarrobas rises everywhere above the top of the hedges.

The fields do not cover the whole area of the annual 


\section{HOW FLOODS ARE MET}

inundations. They are confined to the part where the flood is fertilizing; where it leaves behind it a fine, useful clay which keeps the store of moisture for several months. In other places the current is too rapid. It furrows the soil, leaves large holes in it like the lônes in the flood-area of the Rhone, and.sweeps away the barriers; or the water brings sterile sand which it deposits in long stretches; or again, if it is not drained away in time and evaporates on the spot, it deposits the salts it contains, and the land, looking as if it had a white leprosy, becomes unfit for vegetation.

The floods begin in summer, during November or December. They are caused by the rain-storms in the Tucumán district, and are very irregular. Some of the houses are evacuated, and others are protected by walls of earth, which are raised from hour to hour according to the rise of the waters. Behind these walls the people await the abatement of the flood. When the mud which is left behind has the proper consistency, they till it and sow wheat. The wheat grows in the winter, and is harvested in November quickly, so that the fresh flood may not overtake it.

The caprices of the flood compel them frequently to change the sites of their houses and fields. The ancient village of Loreto was evacuated after a flood, and is now merely a mass of deserted ruins. Round the naked trunks of the algarrobas, killed by excessive deposits of sand or salt, are uniform colonies of plants of the same age and the same species, which invade the area where the adult scrub has been destroyed. The mill has been rebuilt less than a mile away, and has not lost its customers, who have raised their ranchos some distance away. The insecurity of the plots has prevented the development of small ownership. The farmers are tenants of the ranches, which stretch from the river to a considerable distance in the interior.

The use of bañados for agriculture is of long standing. It probably goes back to the pre-Columbian period. 


\section{EXPLOITATION OF THE FORESTS}

Father Dobritzhoffer, who is the first to refer clearly to it, compares the Rio Dulce to the Nile ${ }^{\mathbf{r}}$; and in point of fact, the bañados have some resemblance to farming in Pharaonic Egypt, while there is nothing like them in the irrigated zones of the Andean valleys. The bañados were then devoted to the cultivation of wheat and pumpkins. The pumpkin, which is of American origin, had not yet been eliminated by wheat, which was introduced by the Spaniards. The wheat produced in the bañados maintained a fairly active export trade at the beginning of the nineteenth century, and the bañados were at times called, with some exaggeration, the "granary of the Vice-royalty." It is difficult to trace accurately the movements of the population of the bañados because of the constant changes of the administrative areas in the province of Santiago. The total population of the province is not now more than three per cent. of the total population of Argentina. but its comparative importance was much greater in the middle of the nineteenth century (nearly eight per cent. at the census of I86r). The departments of Loreto, Atamisqui, and Salavina on the Rio Dulce, which live mainly on the estates of the bañados, comprised 46,000 inhabitants in I86I, and only 43,000 in I895. The Woodbine Parish map and Hutchinson's description clearly give one an impression of a dense population in the area of the bañados. I refer elsewhere to the antiquity and constancy of the streams of temporary immigration which spread the population of the bañados over a large part of the territory of Argentina. ${ }^{2}$ The temporary emigration of the Santiagueños is distributed amongst most of the provinces of central and northern Argentina, but it is chiefly of interest in connection with the frontier region. The Santiagueño is a woodman above all else, and the forest area has the advantage over the other labour-markets of wanting workers at all seasons, summer or winter, whereas the sugar-cane

s Historia de Abiponibus.

- See the chapter on population. 


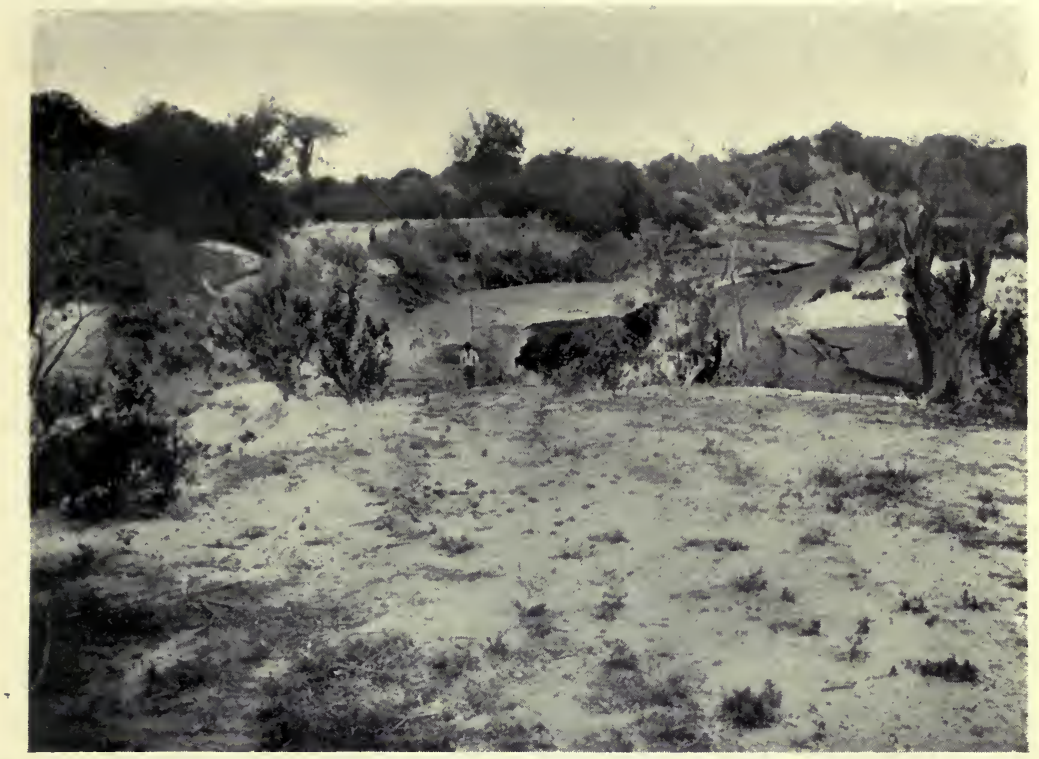

THE LAND OF THE BAÑNDOS.

On the Rio Dulce, near Loreto, in the dry season. Its actual bed, excavated at a recent date by a flood in soft clay, is not yet stable. Photograph by the Author.

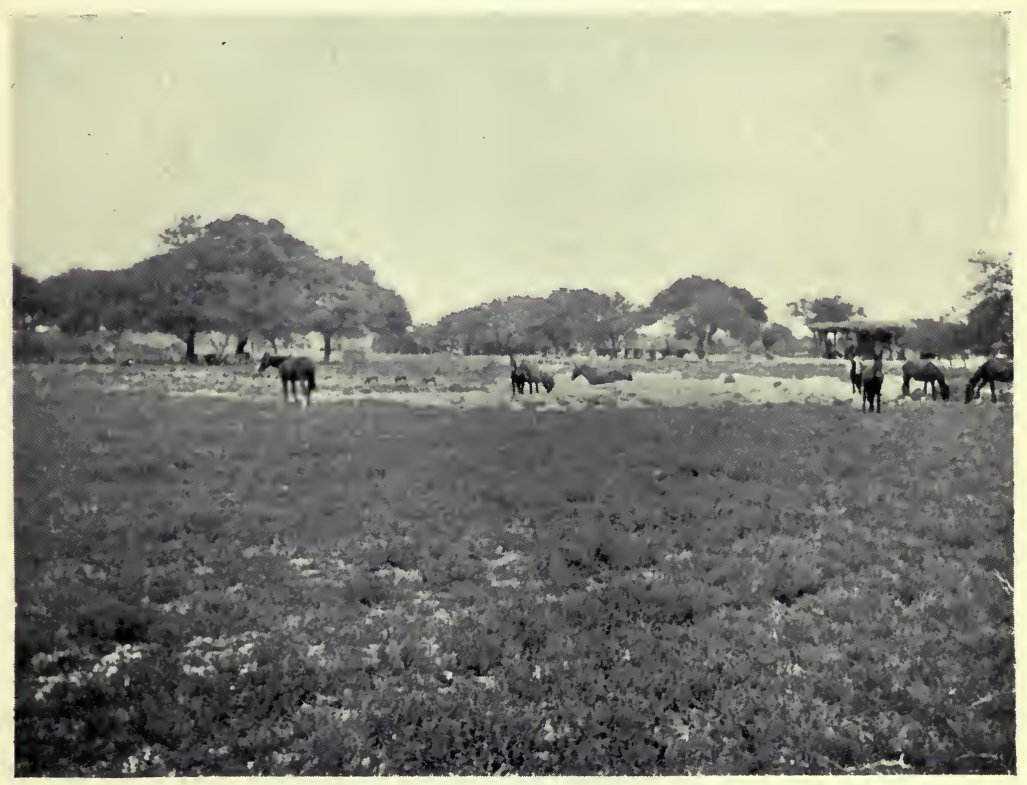

LORETO : FARMING BY INUNDATION.

In the zone of the scrub, where the floods of the Rio Dulce spread. The interior delta of the Rio Dulce is one of the earliest centres of population in Argentina.

Photograph by the Author.

Plate IX.

To face p. soo. 



\section{THE TIMBER WORKERS}

harvest at Tucuman and the harvest in the south only last a few months. They emigrate from the bañados to Tucumán in May ; to Córdoba and Santa Fé in October, November and December; but to the forests of the Chaco all the year round.

Apart from the bañados of the Dulce and the Salado, the province of Corrientes contains the main reservoir from which the timber industry drew its manual workers. Just as at Santiago del Estero, one finds at Corrientes also the opposition between agricultural and breeding districts which is so common in the older colonized regions of South America. The estancieros (ranchers), who are breeders, are the masters of Corrientes, but the line of low hills of sand and red clay, punctuated by lagoons, which crosses the north-western corner of the -province, is not subject to their domination. There the land is subdivided; there are once more fields. Tobacco was an article of export for this fraction of Corrientes, especially after the political isolation of Paraguay, the chief producer of tobacco in the nineteenth century. During the whole of the first half of the nineteenth century the tobacco-buyers travelled all over Corrientes after the harvest, in January and February. The fertile soil, moreover, with a mild climate in which tropical plants flourish as well as those of the temperate zone, provides the elements of a local comfort which is complete in itself. Here again agricultural colonization has created a relatively dense nucleus of population, capable of great increase. Although the administrative divisions do not exactly correspond with the natural divisions, the unequal distribution of the population in Corrientes is made plain by the figures given in the census of 1895 . The density rises in the agricultural areas to eight inhabitants per square kilometre, in the department of Bellavista ; ten at San Cosma ; fourteen at Lomas ; thirty at San Roque. It is only between one and two in the purely pastoral departments (Concepción and Mercedes). 


\section{EXPLOITATION OF THE FORESTS}

Corrientes also has its forests, and in these we find most of the species of the forests of the Chaco, in straight lines, along the water-courses, and in somewhat larger patches on the tablelands which separate the lower valleys near the Paraná. They at first supplied the Curupai bark which was used in the Corrientes tanneries. The yards for the construction of river-boats emigrated from Paraguay to Corrientes at the beginning of the nineteenth century, at the same time and for the same reasons as the tobacco trade. The exploiting of the red quebracho did not begin until about 1850 . In I887 Virasoro relates that fifty ships are engaged in loading with Nandubai timber on the banks of the Rio Corrientes and transporting it to Rosario. I Born on the left bank of the Paraná, the forestry industry emigrated toward the end of the century to the right bank, whither the workers of Corrientes followed it.

We find the same movement further north, on the Paraguay. The exploitation of the woods is in that case a very old industry on the tributaries of the left bank. D'Azara draws attention to its importance. ${ }^{2}$ Robertson found, when he went from Corrientes to Asunción in I8I4, a population of wood-cutters in the marshy belt near the river. During floods they took refuge in the agricultural cantons of the frontier on high ground, where they were well received. It seems, then, that wood-cutting was already a seasonal industry at this time. The exploitation of the forests is now rapidly invading the right bank, which was long abandoned to the wild Indians.

The Santiagueños and Correntinos do not mix. The two zones of expansion and of forestry, of which they are the pioneers, are independent of each other. The

"Val. Virasaro "Los esteros y lagunas del Ibera" in Bol. Instit. Geog. Argent. (vi. r887; pp. 305-3r).

2 Diario de la navegacion y' reconocimiento del Rio Tibicuari (Coll. de Angelis, vol. ii.). 
quechua, which is the language of the bañados of the Rio Dulce, is spoken in the timber-yards of the Chaco de Santiago ; the guarani, the language of Corrientes and the Paraguay, is most common along the river, in the Chaco de Sante Fé. Their respective spheres will not come into touch with each other until the Quimili branch of the Central Norte Railway, which comes from the Santiago province, joins the line of penetration at Resistencia, on the Paraná, in the west.

The forestry industry of the interior and that of the river-districts differ not only in the character of the workers, but in their organization and their market. The variety of red quebracho which is exploited in the west is not quite the same as the variety that is found in the east. Each has a name of its own-quebracho santiagueño and quebraco chaqueño. The former contains ten per cent. of tannin, the latter thirty per cent. The former is cut down for timber, the latter in order to extract the tannic acid. The one is sold in Argentina, and the other sent abroad.

The working of the timber at Santiago has remained in the hands of a number of small capitalists and contractors who do not own the land and do not work there. They are content to buy in small amounts and according to the demand at the moment, the right to exploit the forests (derecho de monte or derecho de leña). The trunks of exceptionally large quebracho provide logs that are sold by cubic measurement, but the district of the quebracho santiagueño mainly exports sleepers. Quebracho sleepers have been used in constructing the railways, both narrow and broad gauge, during the last twenty years on the Pampa. Tall and thin trees make telegraph posts; the smaller branches make stakes for wire fences. In parts of the bush where there is no red quebracho, the retamo is used, to make posts for enclosures, and also the white quebracho, which is sold in round logs. Finally, the forests provide wood for fuel. The works at Tucumán, and the locomotives over 


\section{EXPLOITATION OF THE FORESTS}

a good part of the land, use wood-fuel. The wood of the red quebracho, if left for some years in the yards where the sleepers are made and is rid of the sap-wood, which rots and falls out-the leña campana-is excellent fuel. Charcoal is cheaper to transport than the wood, and can therefore be sent farther over the whole prairie district. It is made in the monte, along all the railways, and especially in the thinner forests on the edge of the prairie.

The forestry of the interior is unstable as well as scattered and primitive. The equipment-saws that are easily taken down and set up-is not costly, and does not require much capital. When one canton of the forest has been exhausted, the saws are taken down and removed. The cuttings are not made in such a way as to allow the forest to recover, and so permit a continuous exploitation. Everything of any value is taken. The quebracho is, moreover, a tree of slow growth. The forestry industry has at times returned, after an interval, to land that had been stripped, but that is not because they had planted a new generation of trees. It is because it became profitable, as the state of the market and the cost of transport changed, to cut down the small trees which had not been considered good enough on the earlier occasion.

When the master obrajero removes, he is followed by the greater part of the workers. But to induce them to emigrate, or to recruit cutters in the bañados who will agree to work in remote or new districts, he has to be liberal and offer higher wages. Hence the conditions of work and the rate of wage are not the same in every part of the forest. The oldest area of working, which is crossed by the Central Córdoba, between the provinces of Catamarca and Santiago del Estero, has a surplus of good workers. On the other hand, the obrajeros of the valley from San Francisco to Jujuy, where the exploitation is more recent, have only a moderate amount of labour at their command: The returns 
are not higher there than in the south, though the forests are incomparably denser and richer. It has been very expensive to bring about a continuous stream of immigration toward the main region of forest work, which is now called the Chaco, along the railway that starts from Añatuya and goes about I30 miles further north. As the worker is on piece-work, the price per sleeper when the work was begun on the Chaco had to be double, on the Añatuya line, what was paid in the older line from Santiago to Frias, close to the bañados.

The work is profitable only within a short distance from the railways. Waggon transport raises the price rapidly. Moreover, the forestry industry is just as dependent on the railways for provisions as it is for the carriage of its wood. The obraje has no source of foodsupply on the spot. The marshy estates which begin to spread in the area of irrigation-canals at Banda, eastward of Santiago del Estero, supply only their customers at Añatuya and the Chaco line. Sometimes the railway has to bring water as well as food. Over a great part of the Chaco de Santiago there is no running water, and the underground sheets are little known, or inaccessible, or salty. The obraje is a land of thirst. In order to meet the demand for water they dig reservorrs like the represas on the ranches, which are filled by the rains. But as soon as the dry season sets in they become stagnant green pools, and the men have to rely on waggon-cisterns.

While the Chaco de Santiago is now a democracy of mall obrajeros and contractors, the eastern Chaco, alongs the Paraná, has quite a different type of society. It is entirely in the hands of the big tannic-acid factories, where the quebracho trunks are stripped and boiled, and their sap is concentrated in a viscous resin. The lofty chimneys of these works rise above the forest at intervals. Here the work assumes a capitalistic and industrial character which it has not in other places. It is con- 


\section{EXPLOITATION OF THE FORESTS}

trolled by powerful concerns, highly organized, which conduct it on a pre-arranged plan. It is true that the works do not deal with the entire output of quebracho, $\mathbf{x}$ but they almost control the market, even as regards the unworked wood which is exported, and they reserve a good deal of it for their branches in Europe. In order to secure the heavy loans which the works represent, the companies that have built them have been obliged to take over large forests, and they have come to own these. The concentration of the area in their hands goes on daily, and the number of companies is reduced by amalgamation or by the purchase of rival concerns and their estates. On the territory of the Chaco, where the administration of public lands was in the hands of the Federal Government, some precautions were taken to prevent the monopoly of the country; but the forests of the province of Santa Fé belong entirely to two firms.

The eastern Chaco has received from Europe, not only the capital that was needed for the construction of works, but also a number of workers, either for administration or for technical direction. These have proved more exacting than the creoles of the Santiago saw-mills. Beside most of the works there are now comfortable villas and brick towns for the workers. The expense was quite prudently incurred, as the industry is less erratic in this region. A tannic-acid factory cannot be removed like a saw-mill. When the timber-supply is exhausted in the district, the works gets its material from a distance, as long as the freightage permits. It depends on the railway, not only for the carriage of its products, as the saw-mills do, but for the supply of raw material.

The works are not all equally wealthy. They are

It is more and more necessary to deal with the extract of the quebracho on the spot the further north one goes toward the interior of the continent because the freights to the exporting ports rise higher and higher. 
scattered over about ten degrees of latitude, north of $30^{\circ} \mathrm{S}$. lat., within reach of the river, which keeps them in communication with the world, and at the same time has enabled them to tackle the full breadth of the forest. The quebracho is particularly abundant north of Santa Fé and south of the Argentine part of the Chaco, where it is the life and soul of the forest. The works which have been set up there, in the midst of the denser forests, have plenty of capital, and this enables them to nurse their supplies and buy timber at a distance. The forest is still almost virginal at their gates, so that they have a long future in front of them. On the other hand, the oldest works, on the southern fringe of the forest, and that of Corrientes, on the left bank of the Paraná, are already paralysed for want of timber.

The works are all at a short distance from the river ; not only for convenience of exporting their products, but because this is the only part of the Chaco where one can find fresh water. And the tannic-acid factory needs a great deal of fresh water. Along the river, in a belt about thirty to sixty miles wide, we find a permanent hydrographic network such as is found nowhere else on the plain. It consists of long series of marshes covered with rushes (cañadas), and in places they become at their mouths regular streams with well defined beds. The underground water also is generally fresh and plentiful, whether it is due to the abundant rain or to infiltration from the Paraná, and many of the works have successfully bored for it. In these parts one suffers from too much water as frequently as from thirst. On these immense and almost horizontal surfaces the water spreads from the cañadas over the whole forest. The railway, and even the houses, then stand out of a sheet of stagnant water, which takes months to disappear. Trunks which are badly placed, lying in the stations to be removed-sometimes, according to the market, lying there for years-are half buried in the mud. The waggons find it hard to move in the roads. Mules, 


\section{EXPLOITATION OF THE FORESTS}

which pay very well in the dry forests of the west, could not make the effort that is required here, and they use oxen-the finest beasts for a muddy country. The long-horned, lean creole cattle drag the waggons with difficulty, and a correntino, with long slender legs, shod with mud, guides and urges them, looking like a crane with his slow and cautious steps. The work of these drivers is much harder than that of the wood-cutters. They earn nearly twice as much, and it is the difficulty of getting enough men for this work that keeps down production.

The importance and stability of the large works has fixed the labour market on the right bank of the Paraná, and there is no need to go to Corrientes to look for men. They come of their own accord. A daily service of small steamers brings them to all the ports which dispatch quebracho. The left bank, on Argentine territory, has also no hiring centre, such as there still are at Asunción and Concepción in Paraguay.

Even on its own land the works leaves the working of the forest to contractors, from whom it buys the timber. But the obrajeros, whether they work in the company's forests or their own, are very dependent upon the works. The contracts vary according as they are owners or otherwise; according to whether they undertake to deliver the timber at the stations or leave it where it is felled; and according to whether they have the requisite oxen and waggons or have to loan these from the company. They draw advances from the company, and, on the other hand, they pledge themselves to purchase what they require for their workers at the company's stores. The profit of these sales increases the revenue of the works. The company monopolizes all trade, both import and export. It exercises an absolute sovereignty over the forest. It has merely deigned to grant the railway company space enough to construct its lines and its stations.

The last forestry centre in modern Argentina is in 
the province of Misiones on the upper Paraná. Posadas is its chief station, and protects its southern outlet. Its influence extends beyond the Argentine frontier, over a small part of Brazil and Paraguay. In Misiones there are two types of forest, which differ a good deal from each other, while neither resembles the quebracho forest. One is the forest of araucarias (pinos) which covers the elevated tablelands at a height above 2,000 feet. The other is the tropical forest, rich in essences and of perennial vegetation, which fills the bottoms and slopes of the valleys. The pine, which is also much worked on the Brazilian tableland, yields an excellent white wood, suitable instead of the northern pine. It would find a ready market at Buenos Aires, but it has never been worked on Argentine territory because of the great distance of the woods from a navigable river. On account of its position on the tableland the araucaria has to wait for the railways of some future date. ${ }^{I}$ As to the leafy tropical forest it includes a number of useful varieties (timbo, lapacho, etc), but the most esteemed of all is the cedar. Its wood is rose-coloured, scented, and fine-grained, and very suitable for furniture. At the time of D'Orbigny's travels the inhabitants of Corrientes were looking out for cedars from the mountains brought down the river when in flood. The obrajes of cedar-wood now extend twenty miles or so on the Argentine bank, and forty miles in the Paraguay bank, which is more even and better for transport. The trunks are floated in rafts down to Posadas; as the cedar, which is less dense than the quebracho, not only floats, but is improved by parting with sap in the water. At Posadas the rafts are taken to pieces, and the trunks are delivered to the saw-mills.

But timber is not the chief forest industry in Misiones, as it is on the Chaco. Beside the obraje in the forest there is the yerbal, a works for dealing with the mate

In Brazil the saw-mills for the araucarian pines are established along the Säo Paolo-Rio Grande Railway. 


\section{EXPLOITATION OF THE FORESTS}

(Ilex paraguayensis). It is well known that an infusion of maté (a kind of tea) is an important element in the food of the western States of South America. Gathering the leaves of the maté has been a profitable occupation for centuries: a unique instance, perhaps, in the forest industries of South America. It has never been interrupted, though it has often changed its locality.

The plantations made by the Jesuits were abandoned when the missionaries were dispersed. After the close of the eighteenth century Paraguay became the chief area of production. Villa Rica seems to have been the most prolific centre of the yerba. After that date, however, the Jujuy basin, further north, was exploited, and the yerbateros, who came from Curuguati, advanced eastward as far as the Falls of the Guayra on the Paraná. In the nineteenth century the trade in Paraguay maté seems to have suffered less than the tobacco trade from the policy of isolation adopted by the Dictators of Paraguay. The descriptions given by Mariano Molas, Demersay, and others, show that the business continued fairly actively. It even extended northward, and reached as far as the Rio Apa. Villa Concepción became a rival yerba market to Villa Rica. The monopoly exercised by the Paraguay Government, however, and the restrictions put upon the navigation of the river, led to the development of the yerba industry in the eastern Misiones on the left bank of the Uruguay. Itaquy served as port of embarkation. In the last third of the nineteenth century the yards moved from the left to the right bank of the Uruguay. Since 1870 the Paraná has supplanted the Uruguay, and the yerba trade has concentrated at Candelaria. This meant the resurrection of Misiones. In I880 San Javier, on the Uruguay, worked up 800 tons of yerba, and Candelaria more than I,000 tons. The yerbales round San Javier began to run out, and the yerbateros had to go further and further up the Uruguay, toward the yerbales of the tableland of Fracan and San Pedro. Candelaria 
was mainly fed by the yerbales of the right bank of the Paraná, on Paraguayan territory. Posadas has now succeeded Candelaria, and the yerbales that depend upon it are scattered over both banks up the Paraná.

The yerbales of Misiones lie outside the tropical forest proper. They are on the lower fringe of the pineforest, and begin at some distance from the river, with which they are connected by muddy and difficult muletracks. Maté can bear a cost of transport that would be fatal to timber. At the point where these tracks reach the river, the river-steamers stop at the foot of a shed that is almost hidden in the foliage. These are the "ladders" of the yerbales.

Work in the yerbales lasts six months out of the twelve. The pruners who collect the bunches of leaves and bring them to the furnaces, where they are dried, include Brazilians, Paraguayans and Argentinians. The Brazilians go to the yerbal to offer their services. The Paraguayans and Argentinians, nearly all from the province of Corrientes, are recruited at Posadas and the sister-town of Encarnación, which is opposite to it on the Paraguay bank.

The hiring at Posadas is done according to a traditional custom that does not seem to have changed for more than a century. The description given by D'Azara is not yet out of date. "The people of Villa Rica," he says, "depend mainly on being hired for the yerbales. The yerba industry is sometimes profitable to the masters, but never to the natives, who work cruelly without any profit. Not only are they paid in goods for the yerba they gather, but the goods are put at so high a price that it is terrible. They have even to pay for the hire of a bill for cutting the maté ... The natives contract as much debt as they can before they start for the yerbales, and as soon as they have done a little work, they say good-bye to the yerbatero, who loses his money. And the yerbatero in turn is exploited by the merchants who control him." Before he starts for the yerbal, says 


\section{EXPLOITATION OF THE FORESTS}

Robertson, the contractor (habilitado) gets an advance of four or five thousand piastres. With this he hires about fifty workers, supplies their needs, and gives them two or three months' pay in advance. The three essential and inseparable elements of the maté business are the yerbal in the forest, a shop at Posadas for hiring and paying wages in advance, and a yerba mill at Rosario or Buenos Aires.

The forestry industry in its various forms is not a definite occupation of the soil by man. After having stripped the forest, it leaves, and the land is open for colonization. Nearly everywhere there is a complete separation between forestry and permanent colonization. They do not employ the same workers; the wood-cutter (hachador) and the charcoal-burner are not the men who clear the soil. The clearing away of the stumps, which must precede agricultural work, is not their business, but the work of diggers. At Tucumán, where most of the workers in the cane-fields are Santiagueños, Italians and Spaniards are used for clearing the soil. The gangs of Mendocinos who go to cut props in the bush round Villa Mercedes will not sign on for clearing the ground in order to plant lucerne.

The history of forestry and colonization is one of the most diversified chapters in the general economic history of modern Argentina. Round the region of the Pampas, the first point where agricultural colonization came into touch with the forest belt is the district of the older colonies of Santa Fé. There it found the forestry industry already long established, on the banks both of the Salado and of the Paraná. The export of timber and charcoal to Buenos Aires and the lime-kilns of Entre Rios was at this time one of the few elements of economic life which Santa Fé had preserved. The colonists did not enter the forest, and did not mingle with the charcoal-burners, but they profited indirectly from their presence by selling them maize. Later, 


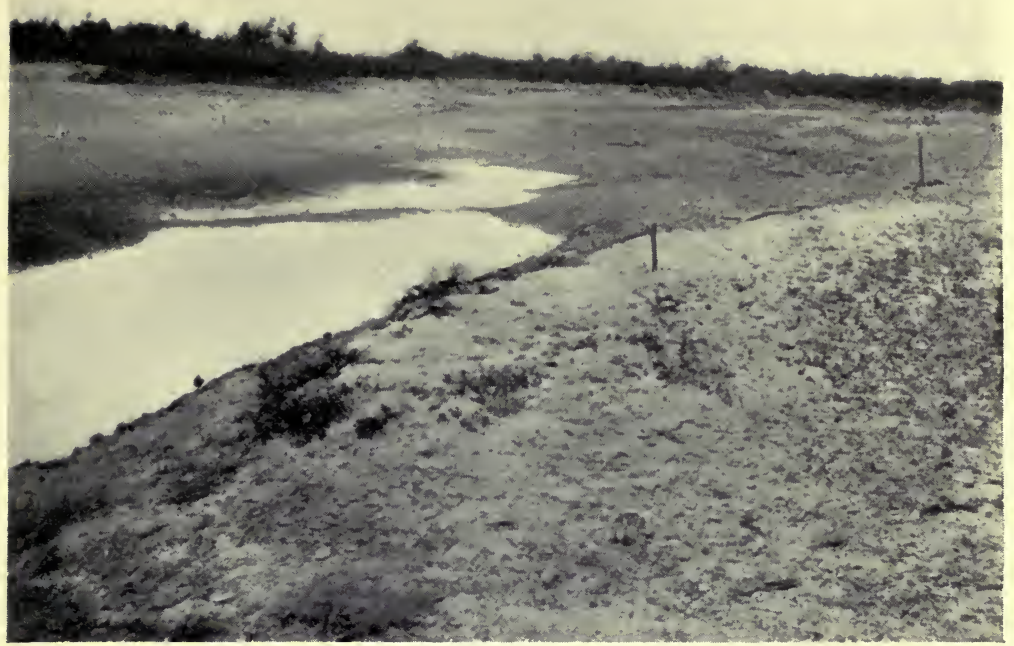

LORETO. THE RIO PINTO IN THE DRY SEASON.

One of the arms through which the flood of the Dulce flows.

Photograph by the Author.

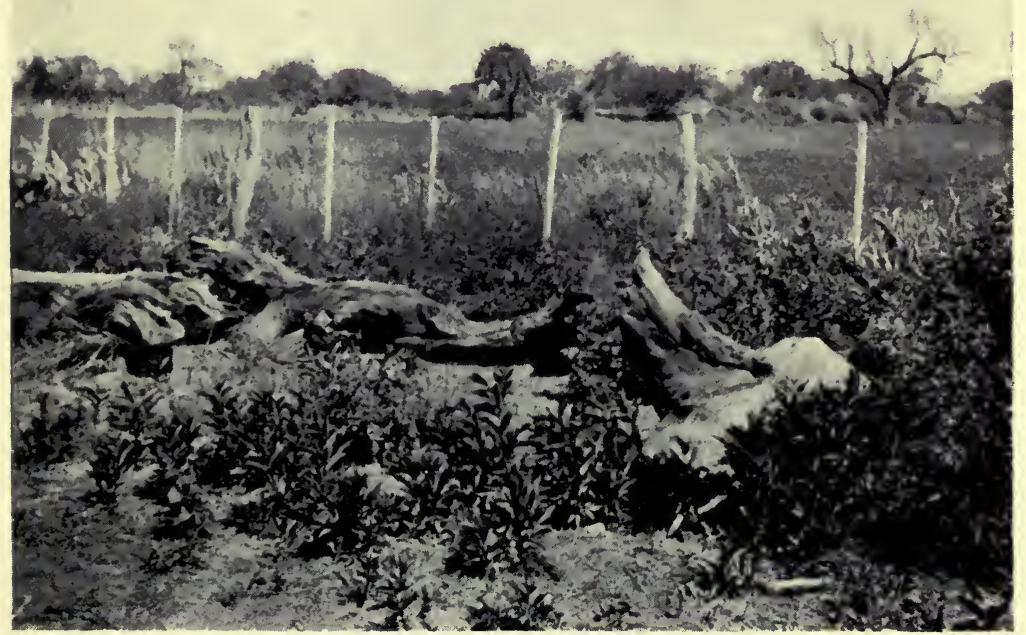

LA BANDA (SANTIAGO DEL ESTERO).

Irrigated lucerne fields on the left bank of the Rio Dulce. Zone of modern colonization: a contrast with the older farms of the flood-zone.

Plate $\mathrm{X}$.

Photograph by the Author.

To face p. II2. 



\section{CLEARING THE LAND}

agricultural work spread over the Central Pampa and the province of Córdoba, as far as the edge of the scrub in all parts of the prairie. Wood-cutting is carried on there, on a small scale, everywhere, at Toay as well as at Villa Mercedes and Villa Maria. The price of the wood he sells is a small supplementary income to the farmer, and clearing the soil helps to fill up his time during the dead season for agriculture. The lands covered with brushwood remained for a long time at a lower price than cleared land. They thus formed a sort of reserve which partly escaped the speculations in land, and on which small owners can find a footing more easily than on the Pampa. There is to-day a movement of Santa Fecinos eastward and southward in the belt of scrub to the south of Mar Chiquita along the line from Lehmann to Dean Funes.

The forest area of the Chaco, in northern Argentina, between the Andes and the Paraná, seems on the other hand to be intended for pastoral colonization. In point of fact, the forest of the Chaco, as well as the lighter scrub which is its southern extension, can be used for breeding without preliminary labour. The Indians have fed cattle and horses on it since the seventeenth century. The herds find food on every side, both in the very numerous clearings (abras) which cross the forest and in the forest itself, where the underwood and the herbaceous carpet grow fairly thick beneath the scanty foliage of the mimosas and quebrachas.

Over a good deal of the western Chaco pastoral colonization is earlier than the forestry. In the district of Santiago del Estero the farmers had advanced far beyond the wood-cutter and the railway; beyond the Salado, almost as far as the existing line from Añatuya to Tintina, where there are sheets and wells of fresh water. The old ranches go as far as Alhuampa. The old pastoral population has taken very little part in the forestry industry. It has been content to profit by it by renting the scrub to the obrajes. It was a sheer gift 


\section{EXPLOITATION OF THE FORESTS}

to them, as the felling of a few trees does not in the least lower the value of the pasture. The forestry has not entailed any change in the ownership of the land or in the breeding methods. The obrajes are merely passing guests whose traces are quickly obliterated.

In the eastern Chaco, however, the wood-cutters are real pioneers. It is they who have made the conquest of the forest, often in direct touch with the Indians, and the ownership of the land fell to them. They have themselves played an essential part in the actual development of breeding.

Leaving the river and travelling toward the forest on the west, one first crosses a narrow belt of estates which form an almost unbroken line from San Javier to Resistencia. These are old colonies, mostly founded about I870, at the same time as the first colonies in the centre of Santa Fé. They had the advantage of being within reach of the river-route, the network of railways that serves the colonies of Sante Fé not being constructed until after I880. They have not shown the same capacity for extension as the colonies on the prairie, but they are firmly rooted, on high and welldrained land, very different from the clays of the Chaco, where the alluvial beds of the Paraná alternate with stuff that seems to come from the left bank. They grow flax, earth-nuts, sugar cane, and cotton. Behind this slight agricultural façade are the large estates of the factories. In the division of the land the industrial firms sought the districts which were richest in quebracho. Buyers of land who had no industrial plans-foreign capitalists and Porteños-and who obtained large concessions in little-known regions, sold back to the factories the plots where there was plenty of wood, after they had taken stock of their property. They converted the remainder into estancias (ranches). The district to the north of the Central Norte Railway, from San Cristobal to Tostado, where the forest, which will presently yield to the plain, breaks into patches and looks 

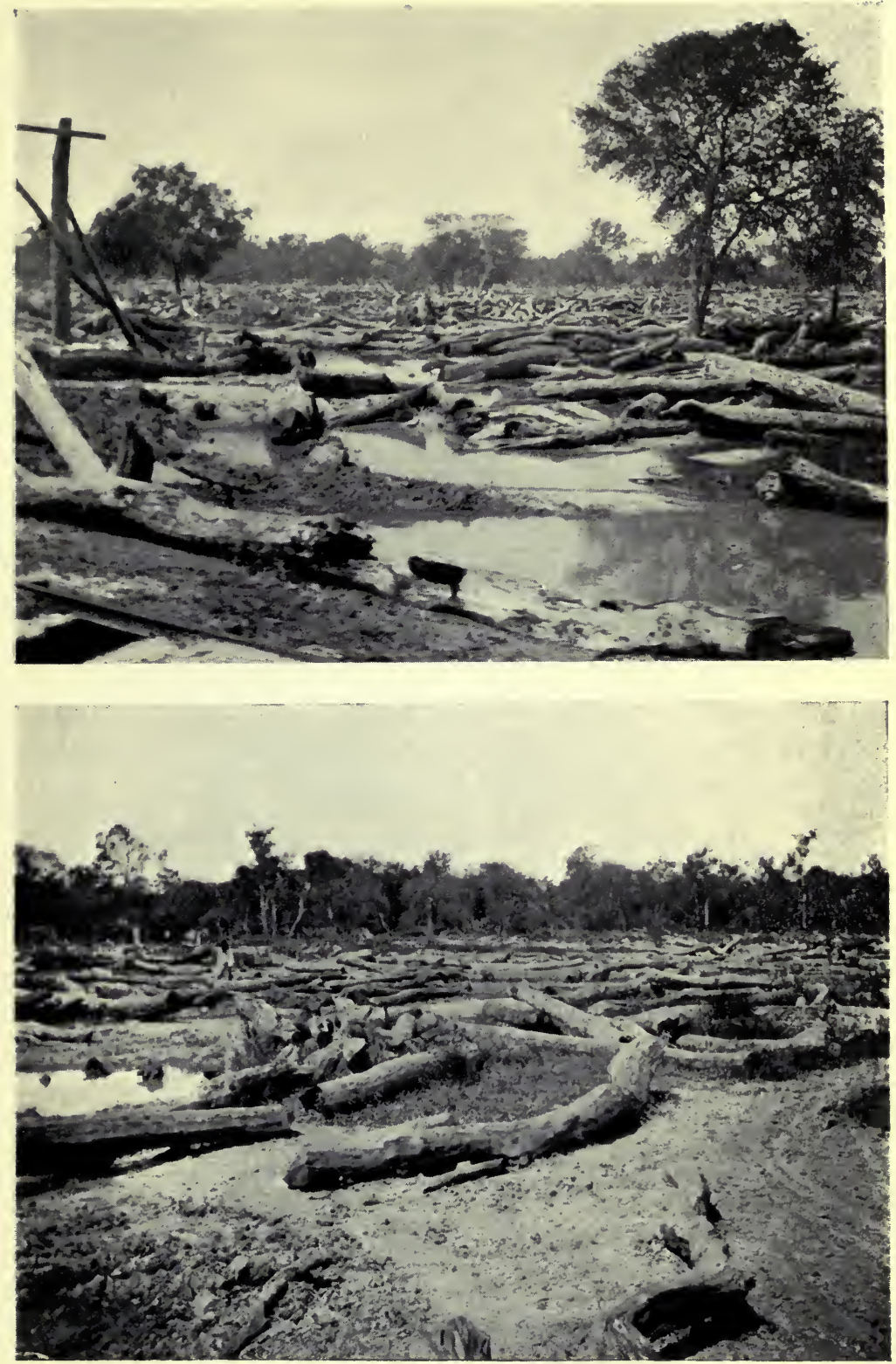

QUEBRACHO TRUNKS LYING AT THE STATIONS.

Eastern Chaco, on the Resistencia line (Santa Fé province). Here the quebracho is exploited for tannic acid, not sleepers.

Plate XI.

Photographs by the Author. To face p. sir6. 

like a park, includes a number of these modern estancias, in which lucerne is beginning to replace the grasses of the natural vegetation.

When one passes to the interior, the pastoral industry at once assumes a more primitive character. The quebracho concerns themselves go in for breeding, in order to make use of their large estates, when the timber has been removed but the works have not yet been set up. They need a large number of cattle, both for moving the timber and feeding their workers, and they endeavour to meet their needs themselves. In this district the forest is capable of feeding a far heavier herd than is the more arid scrub of the eastern Chaco. There are often a thousand head of cattle to 2,500 hectares. To the north and west of that part of the forest where the big companies have taken over the whole of the land, in the province of Chaco, a fairly large number of estates has been created. Further still, on either side of the Bermejo, cattle from Corrientes and the Paraguay have been put on the public lands by men with no rights. As their future is uncertain, they cannot do any expensive work, such as making wells, reservoirs, and enclosures. Sometimes they are compelled by drought to fall back upon the river.

Conditions are quite different in the forests of Misiones. The damp forest of Misiones does not lend itself to breeding. While the forest-workers on the west of the Paraná eat fresh meat, thanks to the proximity of the breeders, in the yerbales and obrajes of Misiones, the use of dried or " jerked " meat (carne seca), which is brought some distance, has remained the common practice, as it is in most parts of tropical America. On the other hand, there is now developing in Misiones an agricultural colonization of an original kind, quite distinct from the ordinary Argentinian type. This is because Misiones is a province apart in Argentina. It really belongs, by its geological structure and its climate, to the Brazilian tableland. The colonies in Misiones are merely an 


\section{EXPLOITATION OF THE FORESTS}

extension into Argentine territory of the great belt of colonies of southern Brazil, which stretches from the neighbourhood of Santa Catalina and the Rio Grande do Sul to the River Paraguay. The Brazilian type of colonization is based upon work with the hoe, in clearings that have been made in the forest by the axe and by fire. Ordinary farming would be impracticable between the large stumps which the clearers have to leave in the ground, to rot there slowly. It would, moreover, be useless, as the land, though rich in humus, is light and aërated. The red soil, a decomposition-product of the diabases which are at the root of all agricultural wealth in southern Brazil, covers a great part of Misiones. The economic inferiority of this agricultural colonization in the forest to the Pampean type which has conquered the grassy plains of the Rio de la Plata, is twofold. On the one hand, the surface that a man can develop is very small. The plots of the Brazilian colonies are ten times smaller than the average estate on the Pampa. On the other hand, it is difficult to get about in the forest, and this hinders the export of the produce.

The colonies in Misiones are still confined to the edge of the great forest, into which they will advance as the agricultural population grows. They form two groups : one on the river above Posadas (Candelaria, Bonpland, Corpus, San Ignacio, and Santa Ana), the other on the slopes of the hills, above the line from Posadas to Uruguay (San José and Apostoles). Foodstuffs, tobacco, fowl and eggs, which they now send by rail as far as Buenos Aires, are their chief resources. As it is possible for them to reach the big markets of the Pampas, by river or rail, they have a certain advantage over the Brazilian colonies. On the other hand, the various elements of their population are inferior. They are very mixed, comprising aboriginals-relics of the ancient Indian or half-breed population of Misiones who have got land but are in no hurry to cultivate it-Poles (grouped in a few villages, such as Apostoles and San José), and German- 


\section{FORESTRY AND AGRICULTURE 117}

Brazilians from the left bank of the Uruguay. At the present time there is a constant stream of GermanBrazilians through the province of Misiones, to embark at Posadas, sail up the Paraná, and settle, further north, in Matto Grosso. No doubt it would be possible to induce part of them to settle on Argentinian territory by offering them suitable land.

These peasant clearers of the land rarely find means to sell their timber. The tropical forest has an immense variety of species, but only a few of these are of value. The obrajero does not cut down the whole forest; he chooses his victims. In the waste land of the colonist it is by no means possible to utilize everything. Even in the area where the forestry industry flourishes, trunks with no faults, felled in order to make room for farming, are pitilessly burned and destroyed.

Yet the indirect advantages of the forestry to agriculture are numerous. Just as in the whole of southern Brazil, it affords a good market for agricultural produce. The crops from the colonies are stored in the shops at Posadas, and from there they go to the obrajes and yerbales. In addition, the industry finds work for more men. On the Rio Grande do Sul, and later on the Paraná, the wages paid for collecting maté have long been the surest resource of the colonies, and it is this that enabled them to subsist during the difficulties of their early period. In Misiones the attraction of the yerbales is not so strongly felt by the inhabitants. There are comparatively few colonists who are willing to leave their plots and hire themselves for distant work. The yerbales find their recruits, not amongst the immigrants from Europe, but amongst the ancient pobladores; that is to say, men who hold land without a title, whose position was recognized when the colony was formed-a floating population, not deeply rooted in the soil.

Agricultural colonization in turn will react upon the forestry industry in developing the cultivation of maté. Large plantations of ilex have already been established 


\section{EXPLOITATION OF THE FORESTS}

above Posadas. Already they enter the common life. They are scattered either over the estates of the national colonies or over the larger estates of the richer colonists ; for planting demands a considerable expenditure. Some of them belong to dealers who also work natural yerbales elsewhere. They are, if possible, set up in the forest, or at least on the fringe of it, in order to have a good supply of wood to dry the leaves. Thus the primitive industry of collecting maté is undergoing transformation while the natural growths are disappearing. 


\section{CHAPTER V}

\section{PATAGONIA AND SHEEP-REARING}

The arid tableland and the region of glacial lakes-The first settlements on the Patagonian coast and the indigenous populationExtensive breeding-The use of pasture on the lands of the Rio Negro-Transhumation.

THE northern limit of the Patagonian region passes to the north of the Colorado, in the latitude of the Cerro Payen and of the ridge which leads from Malargue to the Rio Grande in the sub-Andean zone ( $36^{\circ} \mathrm{S}$. lat)., and to the Sierra de Lihuel Calel in the southern part of the Pampa province. South of this line, from the Andes to the Atlantic, on the territory of the Neuquen, the Rio Negro, the Chubut, and the Santa Cruz, is the region of the sheep farms, their refuge since more profitable branches of farming have driven the sheep from the Pampa. The extensive breeding practised on these poor lands is not profitable enough to justify much expenditure, and is therefore all the more controlled by the physical conditions. It is true that cattle-breeding was once undertaken in the Spanish settlements of the lower Negro, and still exists in western Patagonia at the foot of the Andes, but one never finds there the particular combination of cattlebreeding and sheep-breeding which is characteristic of the Pampean region, in which the main function of the cattle is to improve the pasture and make it ready for sheep.

The climate is trying. The west winds are violent during the greater part of the year, especially on the 
coast, and merely relax a little in the winter. The mean temperature on the Atlantic coast falls nearly one degree for each degree of latitude (I4.6 $6^{\circ}$ at San Antonio, below $4 \mathrm{I}^{\circ}$ S. lat. ; $8.5^{\circ}$ at Santa Cruz, below $50^{\circ} \mathrm{S}$. lat.; and $5.3^{\circ}$ at Ushuaia, below $55^{\circ} \mathrm{S}$. lat.). The summei temperature falls even more steeply, but the difference is less notable in winter $\left(21.4^{\circ}\right.$ at San Antonio, $14^{\circ}$ at Santa Cruz, and $9.2^{\circ}$ at Ushuaia). The low summer temperature does not allow cereals to ripen south of the Chubut. In the sub-Andean valleys the summer is comparatively warm $\left(16^{\circ}\right.$ in January at Diez y seis de Octubre at a height of $I, 800$ feet), but there is severe frost, especially at the beginning of the winter, and no month of the year is quite free from it.

Rain is plentiful in the Cordillera, and on its western border : 800 millimetres at Junin, nearly two metres at San Martin (which the wet westerly winds reach by the gap of Lake Lacar), and nearly a metre at Bariloche, on Lake Nahuel Huapi. It diminishes rapidly, however, as soon as one leaves the mountainous region and goes further east over the tableland. The whole tableland has a rainfall of less than 200 millimetres (Las Lajas I80, Limay I50, San Antonio I80, Santa Cruz I35). It is only south of the Rio de Santa Cruz that the rainfall rises once more (Gallegos 400 millimetres, Ushuaia 500 millimetres). Hence Patagonia as a whole is, with the exception of a narrow belt at the foot of the Andes, a semi-arid region with a sub-desert climate. In the Patagonian Andes the rain falls, as on the coast of Chile, mainly in winter. Between Mendoza, which has the summer-rain feature of central and tropical Argentina, and Chosmalal, in the Neuquen Andes, the contrast is absolute. The summer months there (January and February) are dry, and the rain is confined to the winter months, from May to August. It is the same further south, at Bariloche and at Diez y seis de Octubre. On the 


\section{THE CLIMATE OF PATAGONIA}

Atlantic coast the winter-rain feature is less regular and uniform. At San Antonio the heaviest rains fall in autumn (April and May). There is a secondary maximum in August, and a few more showers in the spring (September and October). South of San Antonio the winter maximum, which is always marked, is cut by a short dry period (July and August at Camerones, June at Deseado and Santa Cruz). ${ }^{\mathbf{x}}$ In the interior, on the other hand, the winter-rain system remains unchanged. The predominance of the precipitations of the cold season is of great importance to the breeders. As a rule, they come down in the form of snow, which melts slowly, and the small quantity of moisture is at least all absorbed in the soil. South of the Santa Cruz the humidity increases, but the rainy season alters. At Gallegos the wettest month is December; at Ushuaia, the rains last from September to March. The snow-season (May-August) is the dry season, and the snowfalls are not heavy enough to interfere with breeding.

The surface of the Patagonian tableland is very uneven, though it bears traces of having been much worn by the agencies of its desert climate, which seems to have lasted through the whole Tertiary Era. Going up the Rio Negro, one sees the grey sandstones and Tertiary tufas which form the cliffs, on both sides of the lower valley. They give place higher up to the variegated marls and red sandstones of the Cretaceous which form the tableland at the foot of the first Andean chains. The core of ancient granites and porphyries crops up at places from under the mantle of Cretaceous and Tertiary sandstones. The horizon of the peneplain passes from the Tertiary and Cretaceous tableland to level masses of crystalline rock, the contour of which

This anomaly is doubtless due to the proximity of the sea and the respite of the westerly winds in winter. The coast, with its cold waters and the land-winds causing the deeper water to rise, has a special climate of fogs and mists. These, which remind us of the garuas of the coast of Peru, do not penetrate into the interior. 


\section{PATAGONIA AND SHEEP-REARING}

has been almost entirely effaced. Volcanic eruptions have occurred until quite recent times, and so eruptive areas are the salient features of the tableland, at Añecon and at Somuncurra, south of the district of the Rio Negro, in the ridge on the left bank of the middle Senguerr, in the Chubut province. The basalts have spread out in sheets, the surface of which seems to have cooled not long ago. Basalt flows are found as far as northern Patagonia, south of Valcheta and Maquinchao; but their chief seat is in eastern Patagonia. They cover the inhospitable tablelands to the east of Lakes Buenos Aires and Pueyrredon. The Rio Chico and the Santa Cruz cross them for the upper two-thirds of their course, South of Coile and Gallegos they spread almost to the coast, and the Tertiary Pampas in this part are dominated by an archipelago of small volcanic cones.

The tableland is crossed from west to east by deep and broad valleys, enclosed between high cliffs, often strangled by ridges of basaltic or crystalline rock, and very little ramified. The ravines (cañadones), which make breaches in their cliffs on both sides, go only a little way into the sandstone Pampa or the lava tableland. Only a certain number of these valleys are occupied by important rivers (the Rio Negro and the Santa Cruz, for instance) which are born in the Andes, but receive little addition from the light rains of eastern Patagonia. Most of the valleys have only intermittent streams (Sheuen, Coile) or are altogether dry and sown with salt lakes (Deseado). The west wind is now the ruler of this network of fossil valleys. It carves their slopes, and brings into them sand, with which it makes dunes.

We must not confuse with these dead valleys the long depressions, with no outlet, which are scattered over the granite and sandstone tableland (bajos, valles, cuencas). Some have obstinately, but wrongly, sought in these the traces of rivers that have disappeared; 
and the bajos of Gualicho and Valcheta have wrongly been regarded as the former bed of the Rio Negro and the Limay. Erosion by wind seems to have had something to do with these depressions. Their persistence, at all events, is one of the effects of the aridity which prevents normal erosion from moulding the surface of the tableland. The chief of them are centres for collecting running water. There is a group of valleys all round them, and alluvial beds accumulate in them.

The climate determines the character of the soil in Patagonia. The rounded pebbles of granite and eruptive rock, so often described since the time of Darwin, sometimes free and sometimes embedded in red sand or limestone, ${ }^{\mathbf{x}}$ are spread over the tableland like aureoles round the masses of rock, and they are particularly abundant in the coast region. On the Rio Negro they seem to be confined to the vicinity of the valley; they disappear as one goes away from it. The progressive reduction in the volume of the Rio Negro gravels, as one goes downward, has been observed to begin in the Andean zone, and it is from the Andes that they come. South of Santa Cruz, in a moister climate, in which the circulation of the water is less localized, the bed is more continuous, and it covers the Tertiary sandstones and clays. It is of fluvioglacial origin, and comes from the destruction of the old moraines, before the excavation of the actual valleys. But it is the wind that explains the concentration of the gravel at the surface. It separates the pebbles from the more mobile material about them. Wherever the outcrop-strata contain pebbles, the wind eventually converts the place into a field of shingle. It has

I The calcareous flag-stone of La Tosca, which is characteristic of the south-west province of the plain of the Pampa, stretches in the south as far as the Rio Negro in the coast-district. On the other hand, it is almost entirely absent a hundred miles to the west, between the Colorado and the Rio Negro, along the line of the railway from Fortin Uno to Choele Choel. 


\section{PATAGONIA AND SHEEP-REARING}

done this with the terraces of the Limay. The Tertiary marine deposits of the coast region also are rich in pebbles torn from the rocky promontories of the shore; hence the extent of stony soils in the coast region. The wind similarly strips naked the angular stones, of local origin and incompletely worn, round the isolated rocks of the desert tableland or 'on the flanks of the secondary ravines.

On the other hand, the bedding action of the wind creates deposits consisting of small and uniform elements from the sands of the dunes to the finest dust. The lightest particles, caught up repeatedly by the squalls and carried to a great height in the atmosphere, go beyond the Patagonian region and reach the bottom of the Atlantic or the plain of the Pampa. Some of this, however, is deposited in the depressions of the tableland, where the moisture fixes it and prevents the wind from regaining it. These æolian deposits in the depressions, a dark-grey clay, which hardens when it is dry, but is softened by water, form two entirely different kinds of soil. If the depression is closed in, or if the circulation of the water is too slight, there is a concentration of the mineral salts ; this is the salitral, either naked or sustaining a halophytic vegetation, which the saline efflorescences cover with a white coat during the dry season. If on the other hand, the underground waters have a free course, the æolian clay forms the mallin. Bushes and fine grasses grow on it, and, as they decay, gradually give it a darker shade and modify its composition. The soil above the mallin is rich in organic elements. It covers the bottom of the valleys between low terraces, covered with faceted pebbles, and dominated by the vertical cliffs of tufa and lava. The contrast between the verdure of the mallin and the arid, dusty, yellow steppe of the tableland is one of the most characteristic features of Patagonian scenery. The area in which mallin has been formed coincides with the most humid districts 


\section{ERUPTIVE SURFACES}

in the vicinity of the Andes and round the higher hills. On the road that runs along the right bank of the Limay, at some distance from the river, on the surface of the tableland, the limit between the country of the salitrales and that of the mallinas passes between Tricaco and Chasico, a hundred miles south-east of Neuquen; it almost tallies with the curve of a 200 millimetres rainfall. ${ }^{-}$Though the word mallin is not used at Santa Cruz, similar æolian soils are found in the western part of the tableland up to this latitude. Further south glacial deposits, clays with moraineblocks, fill the valleys, and from Gallegos onward, cover the greater part of the tableland.

On the eruptive flows of recent date the rock is naked. The wind carries away the products of its decomposition, and the dust accumulates only in the fissures. Traffic is difficult, sometimes impossible.

Toward the west the tableland is separated from the Cordillera by a longitudinal depression, though the continuity of this has been exaggerated. This depression, which outlines the contact between the folded zone of the Andes and the flat zone of the tableland, is very important from the point of view of colonization. Just at the frontier of the steppe and the forest, it is the most hospitable part of Patagonia, the richest in natural resources. Amidst the glacial lacustrine deposits which are accumulated on it there rise masses of different kinds of rock which break it up into compartments, granitic ridges of laccolites exposed to view, eruptive structures that have been dismantled. In the south the sub-Andean depression forms a broad passage between Lake Maravilla and Punta Arenas, about two hundred miles long, enclosed between the basalt cliffs of the tableland on the east and the mountains of the Brunswick Peninsula and

- G. Rovereto, "Studi di geomorfologia argentina: la valle del Rio Negro," Bull. Soc. Geol. Ital., xxxi. r912, pp. ror-142 and 181-237 


\section{PATAGONIA AND SHEEP-REARING}

William IV Land. The bottom of it is a singular glacial landscape, sown with lagoons, punctuated by scattered hills, with an impermeable soil of drift and mud. From Lake Argentina to Lake Buenos Aires the elevated tablelands, which rise to a height of 5,000 feet, back upon the Cordillera, and the sub-Andean depression is interrupted. Similarly, between Lake Buenos Aires and Lake General Paz the contour of the Patagonian tableland is not very marked above the sub-Andean zone. The glacial alluvia at the foot of the Cordillera rise to the level of the tableland, which sinks steadily eastward toward the Genua and the Senguerr. To the north, between Carrenleufu and Lake Nahuel Huapi, the retreat of the lakes has left long narrow beds right in the Cordillera, such as the Valle Nuevo del Bolson, the bed of which has been taken over by the Futaleufu west of the Cerro Situación. Further east the topographical features of the edge of the tableland (the valleys of the Chubut, Tecka, and Norquineo) lie from north to south. Hence within a space of little more than a hundred kilometres the sub-Andean zone has a series of parallel roads, communicating with each other by means of broad, transverse gaps, which at one time were occupied by the lower lobes of the glaciers. The sub-Andean depression does not go north of Lake Nahuel Huapi.

The morphological features of the Patagonian Andes begin at $36^{\circ} \mathrm{S}$. lat. ${ }^{\mathrm{I}}$ The edge of the Cordillera, in

I The great mass of the Patagonian Andes differs considerably in geological structure from the Argentinian Andes. The Paleozoic sedimentary rocks and the lofty chains of the pre-Cordillera cease at $36^{\circ} \mathrm{S}$. lat. The Mesozoic beds-variegated breccie and porphyritic conglomerates, sandstones, limestones, and marls-which form the western slope of the Andes in central Chile, pass to the eastern slope at $35^{\circ} \mathrm{S}$. lat., where they develop in regular folds, in the direction south-south-east, obliquely to the general line of the range. These folds account for the orientation of the interior valleys, which is remarkably uniform from the Rio Negro to the Collon Cura. They pass in the south-west under the sandstones of the tableland. West of this sedimentary zone, the zone of the sub-Andean granites and 
the Malargüe depression, below $35^{\circ} \mathrm{S}$. lat., still presents the typical scenery of the central Andes. The dejectioncone of the Atuel resembles that of the Mendoza. The fringe of torrential deposits, distributed in cones over which the waters spread, is due to the rapidity of the disintegration of the rocks in a desert climate. Keidel has pointed out the part played by the summer rains in transporting mobile elements, which the water drops as soon as the slope diminishes; the amount of precipitation being too slight to permit the formation and spread over the plain of a regular network of streams. From the Rio Grande onward the dejection cones disappear. The streams tend to become permanent, and sink into narrow valleys. The summer rains cease, and the water produced by the melting of the snows has only a feeble capacity for transporting stuff. The soil of the Cordillera is protected by a denser vegetation. The first thickets of molle appear in the valleys, the first scattered cypresses on the slopes, at the Rio Agrio, a tributary of the Neuquen. Then the forest invades the mountain : at first, from $38^{\circ} \mathrm{S}$. lat. to $39^{\circ} 30^{\prime} \mathrm{S}$. lat., a resinous forest of araucarias. At length, at Lake Nahuel Huapi, the forest assumes the general appearance which it has as far as the Magellan region. It is chiefly made up of different kinds of beeches. The coihue (Notofagus dombeyi) is the most conspicuous for about three quarters of a mile, rising above an impenetrable undergrowth of bamboo. Higher up the domain of the lenga (Notofagus

diorites, which have not been exposed further north except at the base of the western slope, opens out in the Patagonian Andes, of which it is the main body between Lake Lacar and the Gulf of Ultima Esperanza. In fine, the Patagonian Andes are characterised by volcanic formations. They are seen on the eastern slope about $36^{\circ} \mathrm{S}$. lat., in the lava-flows and ashes of Payen and Tromen. Further south volcanoes with acid lava and characteristic cones are restricted to the central zone (Lanin, etc.) and the Chilean flank, but flows of fluid basic lava cover enormous stretches at the eastern fringe of the Andes, and they have spread over a good deal of the Patagonian tableland outside the Andean region. 


\section{PATAGONIA AND SHEEP-REARING}

pumilio) extends as far as the fringe of the Alpine forests. The forest does not reach the eastern limit of the lakes. In the sub-Andean depression it is reduced to thickets of nirre (Notofagus antarctica) and mayten and clumps of calafate (something like myrtles).

It is on the Alumine, about $39^{\circ} \mathrm{S}$. lat., that we find traces of glacial erosion, as they spread over the landscape. At present there is no ice on the mountain except on the peaks of Lanin and Tronador, but from the Rio Puelo onward $\left(42^{\circ} \mathrm{S}\right.$. lat.), glaciers clothe all the summits which rise above 6,500 feet. North of the Aisen they form a narrow, but almost continuous, line. From the Aisen to the Calen fiord, and beyond the gap of the fiord as far as $52^{\circ}$ S. lat., the ice spreads in a considerable sheet which in some places attains a breadth of eighty miles. The tongues of the glaciers reach the Pacific below $46^{\circ} \mathrm{S}$. lat., and Lake San Martin on the Argentine slope below $49^{\circ} \mathrm{S}$. lat. In Tierra del Fuego the snow-line is at 2,300 feet, and the glaciers which the snows feed, reach as far as the fiords and Lake Fagnano.

Lake Carri Lauquen, on the Barrancas $\left(36^{\circ} 20^{\prime} \mathrm{S}\right.$. lat.), which was almost entirely drained in I9I4 through the breaking down of the natural dam of soft earth which confined its waters, is not a glacial lake. ${ }^{x}$ The chain of glacial lakes stretches from the Alumine to the Seno de la Ultima Esperanza, and is continued southward by Skyring Water, Otway Water, and Useless Bay-genuine lakes in communication with the Pacific by means of narrow channels. The lakes sometimes lie in a narrow and deep glacial valley, the bottom of which they fill; sometimes they branch out into the neighbouring valleys; at other times they advance eastward beyond the zone of the mountains and spread into round basins surrounded

Pablo Groeber, Informe sobra las causas que han producido las crecientes del Rio Colarado in r9I4. Dir. Gen. de Minas, Geol. e Hidrol., Bol. No. II, series B, Geologia (Buenos Aires, I916). 


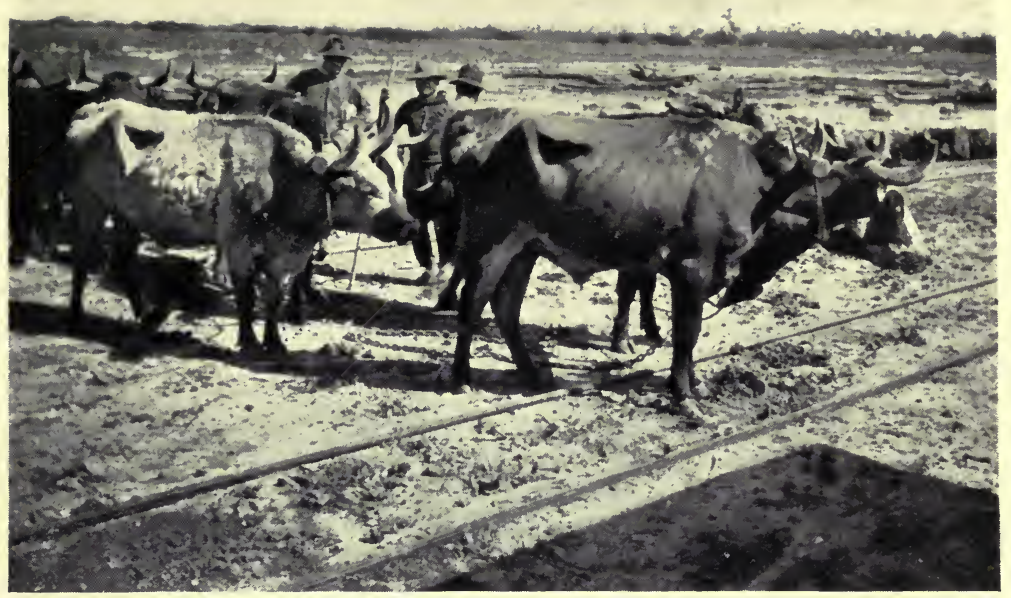

YOKE OF CREOLE OXEN USED FOR THE TRANSPORT OF TIMBER ON THE EASTERN CHACO, OR CHACO OF SANTA Fĺ:

On the Central (or Santiago) Chaco mules are used for transport.

Photograph by the Author.

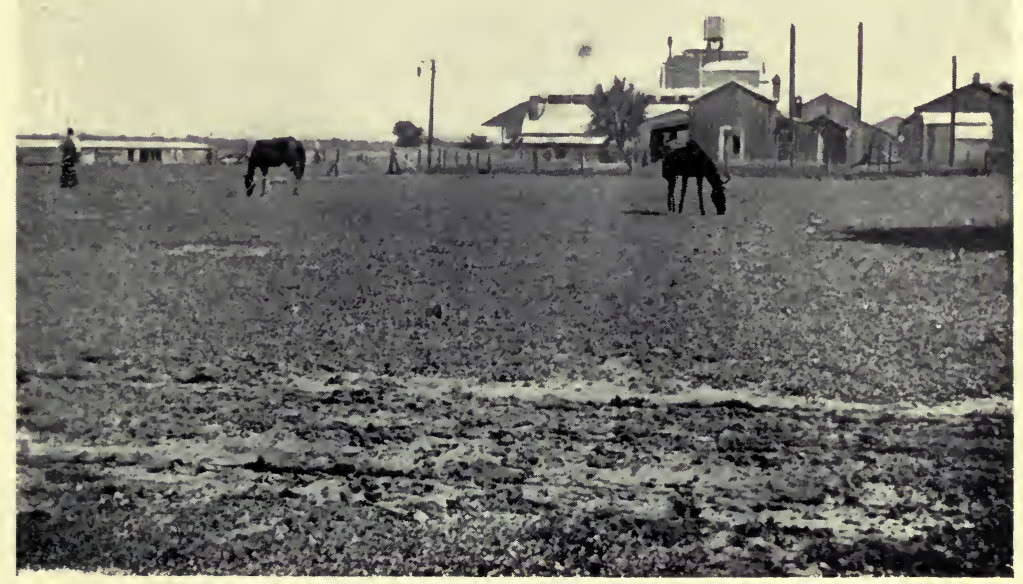

WORKS AT TARTAGAL (EASTERN CHACO) FOR MAKING TANNIC ACID.

These works, built by powerful firms, are permanent centres, drawing timber from a great stretch of forest, while the saw-mills of the Central Chaco move about freely, to be near the felling sites. Photograph by the Author. 

by circles of moraines. The largest of them include groups of ramified fiords, which represent their western half, while the eastern half spreads between lower banks. ${ }^{x}$

Pastoral colonization has now spread over almost the entire surface of Patagonia. The parts that are not yet occupied are of slight extent; they consist

I Most of the lacustrine depressions are continued eastward across the Patagonian tableland in the shape of distinct valleys. The eastern part of the Straits of Magellan is merely a submerged valley on the axis of Otway Water. Useless Bay also is continued eastward by the hollow which ends in the Bay of Sun Sebastian. Sometimes the waters of the lakes flow eastward, toward the Atlantic, along these valleys. Generally, however, the lakes of the western slope are drained on the west by means of narrow defiles across the Cordillera, or on the north and south by rivers which follow the sub-Andean depression and thread them together in the manner of a rosary. The valley which joins the lake to the Atlantic is in those cases a dead valley, and the inter-oceanic dividing line of the waters is marked by the frontal moraine of the old glacier, which confines the lake on the east. This arrangement is found, with surprising regularity, from the Alumine and the Lacar to the Neuquen, and as far as Lake Buenos Aires and the Seno de la Ultima Esperanza at Santa Cruz. The capture of the waters of the eastern slope by the rivers of the Pacific across the Cordillera is fairly ancient, and certainly pre-glacial. But during the Glacial Period the glaciers obstructed the transverse valleys of the Cordillera, and the waters of the eastern slope found their way to the Atlantic once more. With the retreat of the glaciers the valleys of the Cordillera were successively cleared. The lakes, dammed by the glaciers, were suddenly released and their level lowered. The valleys of the Patagonian tableland were finally abandoned, and the topographical accident of secondary importance, which the ancient frontal moraine of the glacier represents, came to mark the limit of the domain of the Pacific. The freshness of the contours of the dead valleys of Patagonia bears witness to the recent date of this conquest, which was too sudden or rapid to be called a " capture " in the proper sense. It has not been accomplished everywhere. From Lake San Martin to Lake Buenos Aires all the lakes of the eastern slope are drained into the Pacific by rivers which flow into the Culen fiord. But further south, Lakes Viedma and Argentino are still tributaries of the Atlantic. They correspond to the zone of the Patagonian Andes which is still covered by inland ice. To the north, in the basin of the Puelo and the Yelcho, where the trans-Andean valleys long ago ceased to be obstructed by ice, the lakes of the eastern slope which drain toward the Pacific are small in size. Their level to-day is much lower than it used to be, and a network of streams has developed east of them, on the earlier lacustrine region, which is now dry. 


\section{PATAGONIA AND SHEEP-REARING}

only of the most desolate regions in the south of the Rio Negro district and north of Santa Cruz. The expansion of white colonization began only about r880. Until then the interior was abandoned to the indigenous tribes and was almost entirely unknown. The Atlantic coast alone had been explored. The travels of Villarino along the Rio Negro and the Limay as far as Lake Nahuel Huapi had left only a faded memory. ${ }^{x}$ North of the Rio Negro, Woodbine Parish (I859), making use of the notes left by Cruz, who had crossed the Andes and the Indian territory between Antuco and Melincue in 1806 , was the first to publish definite information, to which no addition would be made during the next forty years. ${ }^{2}$

The settlements founded on the coast by the Spaniards at the close of the eighteenth century (S. José and P. Deseado) were ephemeral. Only one of them maintained an obscure existence, Carmen de Patagones, some miles above the mouth of the Rio Negro. One of its chief resources was the export of salt. Expeditions for this purpose began on the Patagonian coast about the middle of the eighteenth century (Journey from San Martin to Puerto San Julian about I753, Coll. de Angelis, V). After the revolution, Buenos Aires finally abandoned these costly expeditions by land to the salt districts of the Pampa, and was supplied with salt by schooners from Carmen. During the war with Brazil and the blockade of the Rio de la Plata, Carmen, protected by the bar of the Rio Negro, and the Bay of San Blas were the harbours in which Argentine, English and French privateers concealed their prizes and did their repairs after the storms of the Gulf of Santa Catarina. D'Orbigny visited Carmen during this period of equivocal prosperity. One of the most

- Diario de D. Basilio Villarino del reconocimiento que hizo del Rio Negro en el año de I782 (Coll. de Angelis, vi).

- It is Woodbine Parish who corrects Villarino's mistake in confusing the Neuquen, at its confluence with the Limay, with the Rio Diamante, known in the south of the Mendoza province. 
curious effects of the hospitality offered to the privateers was the unloading upon the Patagonian coast of blacks, intended for Brazil, who were taken from the slave-traders. Thus an unforeseen eddy brought to the south of the Pampean region part of the current of the slave-trade intended for the sugar-cane plantations in tropical America. A number of the Carmen ranches had coloured workers at this time.

Breeding, in fact, was just beginning to spread in the neighbourhood of Carmen at the time. The cattle had been brought by land from Buenos Aires, and had multiplied along the coast and the river above Carmen. South of Carmen, at San José, the cattle had run wild after the fort was abandoned. The Carmen herds were estimated, before the revolution, at 40,000 head. They disappeared during the revolutionary period, but were reconstituted immediately afterwards, and even during the war with Brazil there was an active export of hides and salt beef. Carmen profited mainly by trade with the Indians. It lived in terror of them, and had garrisons to give the alarm on the routes by which they could approach. But this state of chronic warfare did not prevent trade. Near Carmen there was a group of peaceful Indians who served as intermediaries with the tribes of the interior, who were jealous and hostile. Guides and interpreters were found in this colony, and through it came the first news of the interior. The traffic with the Indians continued for a long time to be of great use to the colonists. In I865 the Welsh colony established on the Chubut, which had many difficulties at first, was saved from complete disaster by its trade with the Indians.

The indigenous population comprised two groups : the Tehuelches, or Patagonians proper, men of tall stature, and the Araucans, the Ranqueles, the P'ehuenches and the Pampas. There was no fixed geographical limit between them. The Tehuelches lived in southern Patagonia; but the Araucans advanced eastward 


\section{PATAGONIA AND SHEEP-REARING}

as far as the Pampas region and southward beyond the Chubut. The Indian population of the valley of the Genua and the Sanguerr, south of the colony of San Martin, comprised in I880, ${ }^{\mathbf{x}}$ and still comprises, ${ }^{2}$ a mixture of Araucans and Tehuelches. The Araucans were acquainted with agriculture, but, once they had tamed the horse, they became mainly a pastoral and hunting people, like the Tehuelches.

In so far as they were hunters, the Indians of Patagonia were nomadic. The taming of the horse only made it easier for them to shift from place to place, and gave them a greater range. Their nomadism has too often been regarded as an aimless wandering. They had laws, settled by the physical conditions; and we can gather a few of these. They kept away from the coastal districts except in winter; that is the season when the rains provide water-courses there. It has been observed that names of Indian origin are lacking on the coast of Patagonia. The Spanish navigators who landed there during the summer found the country deserted and the camps abandoned. On the other hand, the share of the Indians in giving names is very considerable in the interior, as far as the foot of the Andes. During the summer the Indians approached the mountains, where they found good hunting grounds. In particular they chased the young guanacos in the breeding season, December and January. Popper has indicated similar migrations amongst the Onas of Patagonia ; they approach the coast in winter, and leave it in summer, to hunt in the interior.3 The district of Lake Nahuel Huapi and Collon Cura had some attraction from afar. The forest of araucarias produced seeds (pinones) which the Indians went to gather; and they also liked the wild apples which

- Carlos M. Moyano, "Informe sobre un viaje a traves de la Patagonia," Bol. Instit. Geog. Argent., ii. $188 \mathrm{I}, \mathrm{pp}$. 1-35.

, W. Vallentin, Chubut (Berlin, r906).

3 J. Popper, "Exploracion de la Tierra del Fuego," Bol. Instit. Geog. Argenl., viii. r887, pp: 74-93. 


\section{WANDERINGS OF THE INDIANS 133}

ripened on the former estates of the old Jesuit missions. The clusters of bamboo on the Cordillera provided the lances of the Aucas and Tehuelches.

Lake Nahuel Huapi is the first stage of the busiest of the routes used by the Indians. It came from the lower Santa Cruz, went up the Rio Chico, and from there northward followed the foot of the Cordillera. D'Orbigny was told about it: "All the Indians who live near the Andes go along the eastern foot of the mountains in their journeys, because they find water there, whereas they would find none if they went by the coast ; in that way they travel from the Straits of Magellan to the Rio Negro." The Indian track only left the sub-Andean depression between the Rio Chico and Lake Buenos Aires, in the district where the high basalt mesetias extend as far as the Cordillera, and on the Pampa of the Sanguerr.

From Lake Nahuel Huapi the Indians of the south descended the Limay and the Rio Negro, and reached the island of Choele Choel, some 230 miles above Carmen, where they met the Aucas and Puelches. There they exchanged their guanacos hides for woollen fabrics made by the Aucas. Choele Choel was the only large, purely indigenous market; the whites never visited it. Geographical reasons fixed the site of this market of the nomads. In the latitude of Choele Choel the Rio Negro approaches the Colorado and the archipelago of the Sierras of the southern Pampa, which mark so many stages on the routes from the Pampa to the Andes. To the south the coast-route, less exposed to snow than the sub-Andean track, began from Choele Choel. The Indians followed this to reach the Gulf of San Jorge and the Santa Cruz in winter, during the rainy season. Darwin notes the importance of the site and the ford of Choele Choel. Villarino had suspected it, and had, as early as $I 782$, pleaded for the building of a fort there. By holding this point, he said, they could prevent the tribes from 


\section{PATAGONIA AND SHEEP-REARING}

attacking Buenos Aires, or from approaching the Patagonian coast in the district of San José. $x$

As far back as we can go, the life of the Indians seems to have been deeply influenced by their relations with the whites. The Aucas brought to Choele Choel, not only the products of their industry, but also objects stolen or bought from the Christians on the Pampa. The report of Musters, who followed a Tehuelche tribe from Santa Cruz to the country of the Manzanas ("land of apples"), shows clearly that the attraction of the Nahuel Huapi region for the Indians was less due to its natural resources than to the presence of the Chilean settlements at Valdivia, from which came across the passes of the Cordillera certain quantities of brandy.

The Indian never took to cattle-breeding. His herd never consisted of more than mares and a few sheep. But trade in stolen cattle quickly became the chief occupation of the tribes. It would, however, be a mistake to imagine that the thievish Indian was merely and always a dreaded enemy of the ranches of Carmen. They sometimes had recourse to his services and profited by his misdeeds. After the Revolution, it was the Indians who helped to fill once more the ranches of the Rio Negro, bringing runaway cattle which had remained in the San José district. Later, Carmen bought the cattle stolen by the Indians at Buenos Aires. From 1823 to $I 826$ the number of the cattle sold by the Indians to the colonists on the Rio Negro is estimated at 40,000. Hence the breeders of Carmen had, as regards the Indians, alternate periods of armed conflict and complicity.

But Chile was always the great market for stolen cattle. Raids (malones) and the crossing of the Cordillera by convoys began in the eighteenth century, and continued throughout the nineteenth, until I880, when

I Informe de D. Basilio Villarino a Fr. de Viedma, Coll. de Angelis, v. 


\section{THE PATAGONIAN INDIANS}

the consolidation of Argentine authority on the eastern side gave a more regular form to the cattle-trade. The convoys came to a halt at Antuco and Chillan from which the Chilean buyers sometimes accompanied the Indian tribes as far as the tolderias on the edge of the Pampa. The trade in stolen cattle made use of all the passes of the Cordillera, from the Planchon pass below $35^{\circ} \mathrm{S}$. lat., which Roca had covered in 1877 by the fortress of Alamito, to the source of the Bio Bio. The one most used was the Pichachen or the Antuco pass. On the tableland the cattle-tracks formed a regular network with innumerable strands, spreading over a width of about two hundred miles. The most northern route started east of the Poitague district and, after fording the Salado and the Atuel, and passing the aguadas of Cochico and Ranquilco, entered the Cordillera at the bend of the Rio Grande. Another track ascended the Colorado and then reached the high valley of Neuquen. A third crossed from the Colorado to the Rio Negro, and, above the confluence of the Limay, to the Rio Agrio or the Alumine.

The first exact information about the range of the Patagonian Indians is supplied by a group of bold travellers who followed their tracks from 1870 to 1880 : Musters, Moreno, Moyano, Ramon Lista, etc. Their discoveries had already outlined the geographical survey of Patagonia when the campaign of $1879-1883$ opened it to colonization.

The story of white colonization since 1880 shows us several distinct streams of population. The first, starting from the region of the Pampa, went from north to south along the Atlantic coast, and gradually extended its sphere toward the interior. The breeders used the sea-route, the ancient Indian track with recognized sources of water, to convey their first herds. In I884, the only spot inhabited on the coast between the Rio Negro and the Deseado was the Welsh colony on the Chubut. In I886 Fontana reports ranches 


\section{PATAGONIA AND SHEEP-REARING}

in the Punta Delfin district, south of the Chubut.I About I 890 the whole district round the Gulf of San Jorge was occupied; and a little later the stream from the north met the stream from the south about San Julian and Santa Cruz. The expansion of colonization was. less rapid in the interior. Ambrosetti tells us of the establishment of the first ranches round the Sierra de Lihuel Calel in $1893,{ }^{2}$ and at the same time Siemiradzki still found few traces of colonization on the Colorado. 3

The second stream of colonization came from the Magellan region. It started in Chilean territory, about Punta Arenas. It was about I878 that sheepbreeding spread round Punta Arenas, and between I885 and 1892 was the most rapid growth of the ranches of the Magellan district. North of the Straits they occupied the lowlands round Skyring Water and Otway Water, then the plateau south of Gallegos. They spread along the Atlantic as far as the Santa Cruz. In 1896 the limit of the sheep-region was on the Santa Cruz about forty miles from the coast. 4 To the west, Puerto Consuelo was founded in 1892 , and in 1896 colonization came up against the mountain barrier which the Cerro Payen and the basalt tableland of the Cerro Vizcachas interpose between Lake Argentine and Ultima Esperanza fiord.

The spheres of primitive colonization in southern Patagonia on the coast still differ from each other in regard to density of population. But breeders in search of unoccupied land have not hesitated to push beyond. In I895 and I900 they passed west of the Gulf of San

× L. J. Fontana, "Exploracion en la Patagonia austral," Bol. Instit. Geog. Argent., vii, 1886, pp. 223-239.

2 J. B. Ambrosetti, "Viage a la Pampa central," Bol. Instit. Geog. Avgent., xiv. 1893, pp. 292-368.

3 J. V. Siemiradzki, Eine Farschungsreise in Patagonien, Petermann's Mitteilungen, xxxix. 1893, pp. 49-62.

4 J. B. Hatcher, Reports of the Princeton University expeditions to Patagonia I 896-9 (Narrative of the Expeditions and Geography of Southern Patagonia, Princeton, 1903). 
Jorge toward the basin of the Sanguerr and the Genua, (establishment of the Sarmiento colony, south of Colhuapi, 1897 : establishment of San Martin on the Genua I900). Since I900 the population has also advanced up the Santa Cruz and the Rio Chico as far as the zone of the Andes, and the lagoon which still existed twenty years ago, between the district of the Sanguerr and that of Lake Argentino, and is easily recognized on the maps of the Frontier Commission, has been almost entirely filled up.

The story of colonization in the northern part of the Patagonian Andes is more complicated. Immediately after the campaign of $\mathrm{I} 883$ the valleys of the Neuquen were invaded by Chilean immigrants, half-breeds of the frontier, who cannot always be easily distinguished from pure Araucans. A certain number of Chilotes, and even Germans from the southern colonies of Chile, were mixed with the halfbreeds. This stream of immigration had begun before the conquest. As early as I88I Host notices that there are at Chosmalal various families of Chilean farmers who held their lands from the Indian cacique. During the summer they took care of the migratory herds from the Chilean plain. Once the country was pacified, they grew rapidly in number. It was they who provided the manual labour for the placer miners of the Neuquen, where gold began to be worked in I8go. The area of Chilean colonization extends from the Rio Atuel, where Villanueva found Chilean immigrants in I884, to the south of Lake Nahuel Huapi, where Chileans were still met by Vallentin in I906, on the Rio Pico, close to $44^{\circ} \mathrm{S}$. lat. ${ }^{\mathrm{I}}$ South of Nahuel Huapi there is no regularly used route across the Cordillera. ${ }^{2}$ The Chilean colonists of the southern zone came from

× C. Villanueva, "De Mendoza a Narguin," Bol. Instit. Geog. Argent., v. 1884, pp. I 7 I-4.

: Chilean woodcutters have sometimes got as far as the eastern valleys in search of larch, but these were nomads who did not settle. 


\section{PATAGONIA AND SHEEP-REARING}

the north, therefore, along the eastern foot of the Andes. Bailey Willis calculated that there were 2,000 Chileans in a total population of 3,500 in the sub-Andean area from Nahuel Huapi to Diez y seis de Octubre. The total number of Chilean immigrants may be about 20,000 . It is not on the increase, as immigration from Chile was suspended from 1890 to I895. Since the reconstruction of the frontier the Chilean Government has tried to bring back part of the emigrants to its own territory. Many have gone to settle in the valley of the Lonquimay. In I896 Moreno saw traces everywhere in the valley of -the Collon Cura of the departure of Chilean colonists who had left the country.

At first it was only the Argentinians of the western provinces, San Juan and Mendoza, who vied with the Chileans for the soil. It is they whom Furque found in 1888 at Roca, on the Rio Negro. But beginning with I890-95, immigrants of various nationalities have settled on the Neuquen and the Negro. ${ }^{\mathrm{I}}$ Foreign capitalists organized their first ranches there. In I888, on the other hand, the Welsh of the lower Chubut, led by Indian guides, went from the coast to the subAndean region, and settled in the valley of Diez y seis de Octubre. Between I895 and 1900 the neighbouring valleys began to be inhabited, and the colonization areas of Nahuel Huapi and the Sanguerr came into contact. ${ }^{2}$

The most striking feature of colonization in Patagonia is the very low density of population. The Census

I Furque, “Descripcion del Pueblo General Roca," Bol. Instit. Geog. Argent., ix. I 888 , pp. 124-132.

2 In spite of their importance we must regard as mere episodes in the story of Patagonian colonization the influx of population caused on the eastern coast by the discovery of placer-gold at Cape Virgenes and on the Atlantic coast of Tierra del Fuego (1884), and the discovery of petroleum at Rivadavia (1907) in the course of drilling in search of water. Rivadavia is already, with its 3,000 inhabitants, one of the chief centres in Patagonia. 
of I9I4 gives $8 \mathrm{I}, 000$ inhabitants altogether for the territories of the Rio Negro, the Neuquen, the Chubut, the Santa Cruz, and Tierra del Fuego. A well-kept ranch of 25,000 square kilometres has only a staff of about a hundred men at the most, counting strangers, settled on its land; three hundred inhabitants, or scarcely more than one to ten square kilometres. This population falls into two distinct classes. One is the class of proprietors with regular titles : a rooted and stable class. At first the Government granted enormous concessions, which were taken up especially by English buyers, but it now seeks to break up the land, and the plots which it puts on the market for new pastoral colonies have not more than 625 hectares. This is too small for breeding, no matter how good the situation may be, and there will inevitably be, one would think, a concentration of estates in the hands of a few proprietors. The other part of the population occupy lands which they do not own. They are displaced steadily as the regular concessions are sold to new ranches. They live, so to say, on the margin of colonization, and are more and more restricted to the poorest lands. Sometimes these intrusos or pobladores get hospitality for their herds on the land of some ranch in return for their services. They have little capital, and never make material improvements. They take no care to nurse the pasture, and it matters little to them if it is impoverished.

The climate divides Patagonia into two distinct regions. In the west, the moist Andean zone is suitable for cattle-breeding. About 1870 the Chileans of Valdivia hunted wild cattle in the Nahuel Huapi district. Similarly the Frontier Commission met large herds of wild cattle on the shores of Lake San Martin, which were not yet occupied. Sheep do not get on well in the moist zone, where the rains have washed out the soil and carried away the salts which seem to be indispensable to the sheep. It is the arid tableland that 


\section{PATAGONIA AND SHEEP-REARING}

is the land of the sheep. There it has displaced cattle, even in the area which the early breeders at the end of the eighteenth century had filled with cattle. Between the sheep-area and the cattle-area is a mixed region, where the two are combined. It extends more or less according as the transition from a moist to a desert climate is gradual or sudden. It is especially important in the districts where colonization is already old, as in the Fuegian and Neuquen regions. It is lacking in districts where the colonization is recent (Chubut and Santa Cruz), where the sheep-breeders have had a free run as far as the Andes. The ranches of the Cordillera, which specialize in cattle-breeding, all have small flocks of sheep for their own use, their staff being so small that it does not pay to kill the cattle.

The sheep-area is by far the more extensive of the two. The patches of agricultural colonization are very scattered and small on its surface. They are restricted to the river-oases of the Rio Negro and the Chubut. These small tilled districts have preserved a remarkable economic independence as regards the pastoral zone, in which they seem lost. Thus the farmers on the Chubut exported their wheat to Buenos Aires until about I900, and they still send their bales of dry lucerne there. Some of the ranches have tilled small oases in suitable places, but these are merely intended to increase their stores of fodder; not for their flock of sheep, but for the saddle-horses used in watching the estate and the draught-horses used for transport.

The pastoral capacity of the Patagonian scrub is, on the average, from 800 to $x, 200$ head of sheep to 25 square kilometres: less than a tenth that of the prairies of the eastern Pampa. The ranch fixes its residence in the best part of the estate, where there is least fear of a shortage of water, and where pasture is most plentiful. To this the sheep are brought periodically to receive disinfecting baths against the scab, 


\section{SCARCITY OF FRESH WATER 141}

and for shearing. These incessant movements toward the centre of the ranch cause an almost permanent strain on the pasture, and this is one of the chief anxieties of the breeder. The area of the estate is divided as soon as possible into sections (potreros) by steel-wire fences, which enables them to watch over the reproduction and improvement of the flock and make the best use of the pasture. Fencing is more advanced near the Cordillera, as timber for the posts is found there.

Certain districts are still uninhabited on account of the lack of water. Some of the sources of water are permanent. The water issues at the base of the volcanic rocks, when the underlying rock is impermeable, and above the various levels of the marl in the Patagonian swamps; for instance, in the cañadones round the Gulf of San Jorge. Besides this, the rain and melting snow leave on the surface of the tableland a great number of pools, which evaporate in the dry season. These are temporary supplies, the manantiales, to which the breeders are reduced over large areas of the tableland. Most of the stagnant sheets of water which are permanent are saline. The proportion of salt in them is very variable, and changes in each case according to the cycle of dry and wet years. The water of the Carilaufquen was fresh in I900, and in I9I4 it had become brackish, though it could still be used for the flocks.

Finding permanent sources of water is the first concern of the breeder. In some districts he has succeeded in tapping sheets of fresh water by means of wells. There are none of these wells in the crystalline zones, the closed hollows, where the sheets of water are often large, but they are always saline. Neither are there any in the red sandstone district, the dryest of all. In the western region the wells are sunk in the arid valleys, along the track of the underground stream. Thus the Picun Leufu, the visible course of which is 


\section{PATAGONIA AND SHEEP-REARING}

lost seventeen miles above its confluence with the Limay, may be traced by a continuous line of wells. It is especially in the coastal districts that the wells have transformed the conditions of breeding. Water was first discovered at the foot of the dunes, along the coast itself (district of Viedma, San José, etc.). Since then deep borings have been made over the whole of the Tertiary platform on both sides of the lower part of the Rio Negro, north of San Antonio. There every ranch has its sheet-iron tank, sheltered by a clump of tamarinds, with a windmill to fill it.

All pastures are not equally available in every season. Those which are at a height of more that 4,000 feet in the north, and 2,300 to 2,600 feet in the south, are covered in winter with a thick mantle of snow. These are summer pastures. During the winter the animals are brought down to the principal valleys or to sheltered cañadones below the level of the tableland. The mallin is, as a rule, a winter pasture. When it is too wet, however, it is treacherous, and the animals are buried in it. They have to wait for fine weather before going into it. The pastures, too, which have no permanent water supply, or have only manantiales, which dry up at the beginning of summer, can only be used during the winter. Hence each ranch has to have, besides its assured water supply, a suitable combination of summer and winter pasturage, and it is far from certain that this will be found on every estate, cut up geometrically for colonization, as they were, by the administration of lands.

The constitution of the flock and the first occupation of the land have compelled breeders to undertake difficult journeys, and more than one of these proved disastrous. The earliest arrivals, driving their sheep along little-known tracks, could not avoid losses in crossing the arid parts of the tableland: parts which D'Orbigny, translating literally the Spanish word 


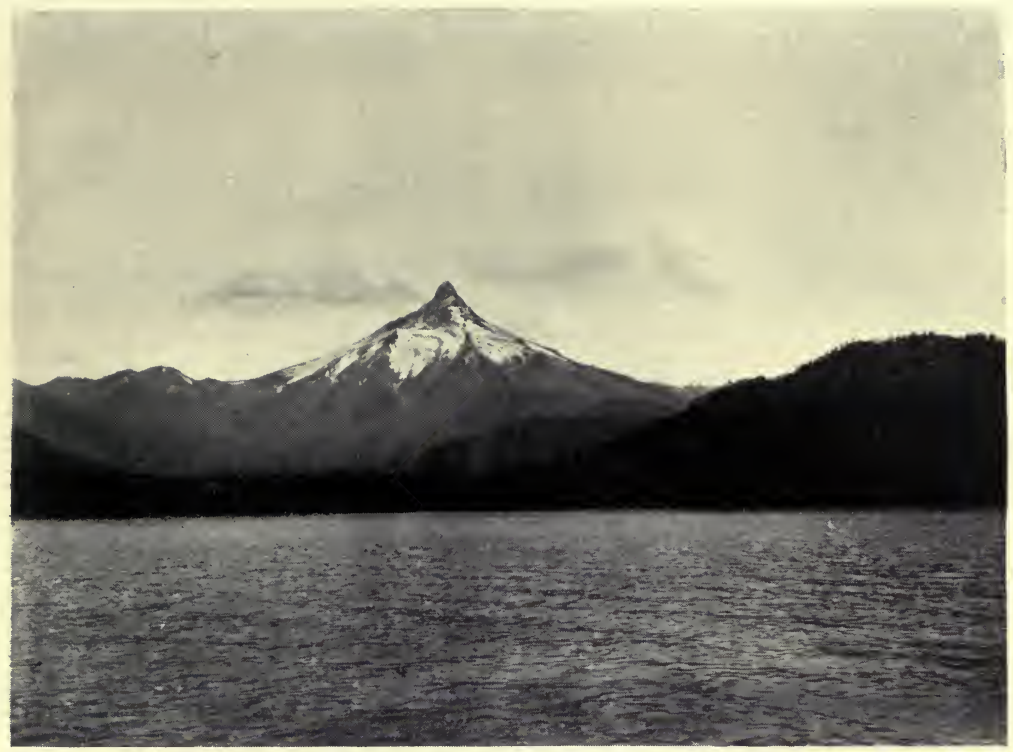

THE VOLCANO PUNTIAGUDO.

On the Chilean side, to the north of the road from Lake Nahuel Huapi. The glaciers come down lower on the western side, as the moist winds come from the west, and the rain becomes less and less frequent as one goes eastward toward the Patagonian tableland.

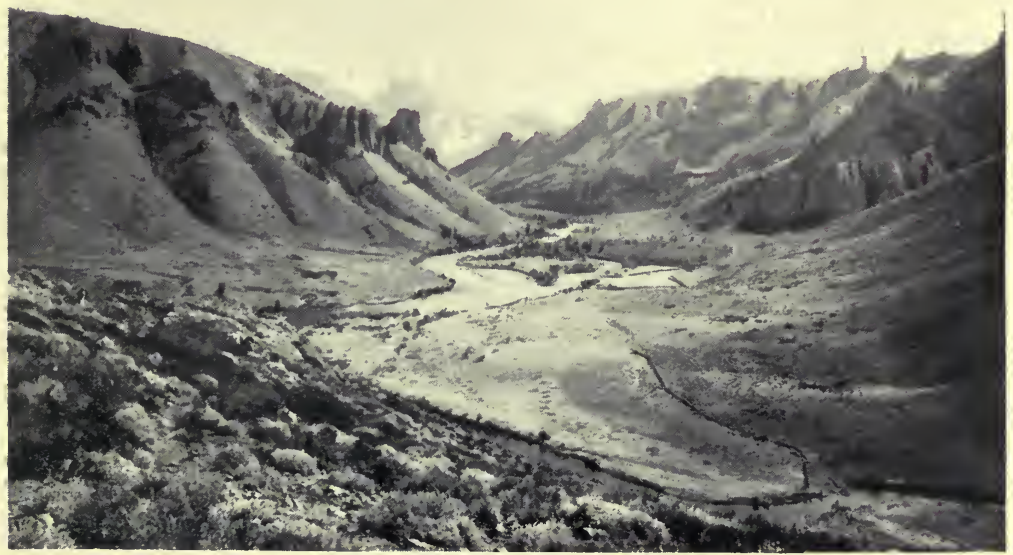

CERCAS ON THE LIMAY (RISING IN LAKE NAHUEL HUAPI), NEAR THE CONFLUENCE OF THE TRAFUL.

Here the Limay enters the sub-desert tableland. Last trees (cypresses) in the valley in the foreground. Photograph by Bailey Willis. 

travesia, calls " crossings." I When the ranch is established, the breeding does not necessitate any further movements of the flocks to a great distance, apart from certain special migrations, or "transhumations," which I will consider later. It is on each ranch, sometimes on each group of ranches combined in a single estate, that they pass alternately from winter to summer pasture. The only transport necessary is that of wool. The fleeces, which the west wind has heavily laden with dust, are collected in the sheds belonging to the ranch, or, in the case of the intrusos, on the premises of certain small traders (bolicheros) who are scattered over the tableland even at its extreme limits. Convoys of wagons then take them to the ports on the coast.

For some years now, however, wool has ceased to be the sole product of the ranches. A little before I895 the first slaughter-houses, for killing the older sheep that were no longer fertile, were erected on the Straits of Magellan. Refrigerators have succeeded these, and were opened at Puerto Callegos and San Julian. A third refrigerator is being constructed (I9I5) at Puerto Deseado. In southern Patagonia, also, part of the flock is sent to the refrigerators or to the slaughter houses of the Pampean region. The creation of the refrigerator has compelled breeders to adapt their work to the new economic conditions. The merino breed is being eliminated by the Lincoln in all districts which feel the influence of the refrigerator ; the Lincoln is of greater weight and quicker growth, but the merino survives in arid northern Patagonia.

Besides this, the establishment of the refrigerators has caused important movements of transport. The flocks which are to go to the refrigerators or the northern railways are moved in the good season, after the shearing,

- The search for possible routes for cattle in the districts that were not yet colonized helped in the study of Patagonia. Moyano was doing this when he explored the route from Santa Cruz to Lake Nahuel Huapi. 


\section{PATAGONIA AND SHEEP-REARING}

from November to April. The routes they take are not invariable. One of the most frequented, leading from the sub-Andean tablelands to San Julian, follows the Santa Cruz valley. When the land was cut up, there was no reason to foresee these movements, and nothing was done to facilitate them. The roads cross the ranches, which are compelled to allow it. It is a serious burden for some of them, unless they can make a profit out of their situation on the road by hiring pasture for the flocks as they pass.

The Andean zone itself is still mainly pastoral, but it is nevertheless far more varied and richer in possibilities of development than the tableland. Agriculture is already combined with breeding in that area.

The name vegas, which in the Puna and at San Juan means alpine pasture, is applied here to tilled patches in the Andean valleys. They are found in the north in the valley of the Neuquen, round Chosmalal. In the south, the valley of the Rio Pico marks the limit of cultivation. Irrigation is almost always necessary north of Lake Nahuel Huapi, where the vegas have, as a rule, a soil of coarse alluvia or permeable tufa, which dries up quickly. Water is plentiful, it is true, and increases in quantity rapidly as one travels southward. The chief obstacle to the extension of cultivation is the frequency of frost in spring and summer. The deep hollows of the sub-Andean depression south of Lake Nahuel Huapi, the height of which drops to $I, 000$ feet at the Bolson, and $\mathrm{r}, 600$ feet at Diez y seis de Octubre, have no frosts in summer, and they sustain small agricultural communities. At higher levels, in the basin of the lake or on the vegas of the Traful and Lake Lacar, at an altitude of about 2,600 feet, the distribution of the summer frosts is closely related to the contour and lie of the land, which may facilitate or impede the circulation of the layers of cold air, and the play of what has been called atmospheric drainage. The valleys which are very open from west to east, 
at the outlet of the lakes, where the west winds have a free passage, are little liable to frost. Wherever frost is frequent, cultivation has to be restricted to fodder plants. The more favoured cantons, which grow wheat, rye and potatoes, help to feed the local pastoral population, and export part of their produce to some distance on the tableland.

Cattle-breeding is, like sheep-breeding on the tableland, practised both by the pobladores on public lands and by ranchers who have settled on regular concessions, which they have worked up and fenced round. The high alpine pastures, above the fringe of the forest, are partly used, from December to March, as summerpasture. The forest also serves for pasture; it is a sort of common land, available both in winter and summer. Below the height of 3,500 feet the clumps of bamboos in the underwood provide shelter during the winter and fodder which is not buried under snow. The fires lit by the breeders have changed part of the primitive forest into a scrub which has been invaded by a leguminous climbing fodder, and it has superior pastoral capacity to the forest. East of the forest, the prairie, which is too much exposed to the winds, is not generally suitable for winter-pasture. The cattle take refuge in sheltered valleys and in the mayten thickets which follow the depressions. Bailey Willis puts the pastoral capacity of the virgin forest at 400 cattle to each 2,500 hectares, 600 for the burnt forest, and 350 for the sub-Andean prairies. The essential problem in connection with the question of completely developing the pastoral resources of the sub-Andean region is the problem of transit. There are no roads from one district to another and to the higher prairies. The fallen trunks which lie about the forest obstruct the way of the cattle. Collecting the animals for sale and watching them are both difficult.

It seems that the profit of exploiting the timber must necessarily be small. The forest, thinned by 


\section{PATAGONIA AND SHEEP-REARING}

fire and difficult of access, is partly composed of trees that are too old. The libocedrus has disappeared from one-third of it. The larch, which is the most valuable, passes into Argentine territory at few places. Sawmills are not so numerous on the eastern slope of the Andes as they are in the Magellan area.

The essential function of the forest is, according to Argentine experts on forestry, to control the watercirculation. In this land of glacial erosion and recent captures, where the water-courses have always a great variety of form, and there are lakes to make their output more regular, it is particularly easy to make use of hydraulic power. "White coal" will, Bailey Willis says, make a great industrial region of it, and plant an urban life in it. Bailey Willis, whose optimism and prophetic gift will not fail to surprise the European reader, has drawn the plans in detail of a future town of 40,000 souls at the eastern end of Lake Nahuel Huapi. The Patagonian land will supply the raw material of its industries; timber, leather, and wool.

One, at least, of the indispensable conditions of the development of urban life is fully realized in the district of Lake Nahuel Huapi and the Limay. It is a remarkable meeting-place of natural roads, and its economic value will increase in the future. It is the point where the road from eastern Patagonia by the sub-Andean depression, from the Gulf of San Antonio on the Atlantic, and from the Rio Negro by the Limay, and the roads that lead to Chile across the Cordillera, meet. The whole zone of the Andes between $36^{\circ} \mathrm{S}$. lat. and $42^{\circ} \mathrm{S}$. lat., the latitude of the southern part of the Chilean plain, has numerous and easy passes. There has always been close communication between the two slopes, and people have emigrated freely from one to the other. But north of $39^{\circ} \mathrm{S}$. lat. the passes are rarely lower than 5,000 feet. They are covered with snow in the winter, and can be used for traffic only in certain seasons. It is not the same 


\section{TRANS-ANDEAN ROUTES}

south of the volcano Lanin. That is the beginning of the glacial valleys which go to the heart of the Cordillera, some of them crossing the mountains from east to west. They have not yet been entirely explored. The Bariloche pass, south of the Tronador, by which the Chilean missionaries reached Nahuel Huapi in the eighteenth century, is no longer used. The Cajon Negro pass, west of Lake Traful, through which Bailey Willis traces the line of a southern trans-Andean railway, was only recently discovered, and the valleys which run into it on the Chilean side are not yet well known. The two best-known trans-Andean routes to-day are the Perez Rosales road, which leads from Chile to Nahuel Huapi by the north of the Tronador, and further north, the road from Lake Lacar to San Martin. Both these have received some attention, and the lakes are connected by telegraph or telephone. The frequent need to unload and reload makes the traffic costly, but it is permanent and is not interrupted in winter. The reduction of the export of cattle to Chile has cut down the traffic for a time, but it is sure to recover. The permanent importance of it is one of the facts most clearly written by nature upon the soil of South America.

It is not easy, in the absence of documents, to attempt to give for Patagonia as a whole a detailed description of the pastoral industry, and to follow step by step on the spot its efforts to adjust itself to the natural conditions. But the analysis may be attempted in regard to the region between San Antonio and Lake Nahuel Huapi south of the Rio Negro, I the valley of the Rio Negro, and the tableland which stretches westward between the Neuquen and the Limay. This part of Patagonia is now easily accessible, and it is entered by two parallel railways. One starts from

I This was the area studied by the Commission of which Bailey Willis was chairman. 


\section{PATAGONIA AND SHEEP-REARING}

San Antonio on the Atlantic, and goes westward to Lake Nahuel Huapi. It has (I9I4) reached Maquinchao, on the tableland, mid-way across the Andes. The other starts from Bahía Blanca. At Choele Choel it enters the valley of the Rio Negro, and ascends it as far as the confluence of the Neuquen. Then it goes I30 miles westward as far as Zapala, at the foot of the first sub-Andean chains. Each of these lines is ambitious to attract the trans-Andeans. At all events, they are in a hurry to reach the humid zone at the foot of the Andes, which could maintain a busier traffic than the desolate tableland.

The railway from San Antonio, and the road which is a continuation of it west of Maquinchao, cover a distance of 320 miles from the Atlantic to the Andes, and cross five distinct regions. The first is the coastal plain, composed of horizontal marine Tertiary sedimentary rocks, both of sand and clay. The plain rises slowly toward the west, and it attains a height of 650 feet at a distance of seventy miles from the coast. This coastal platform divides, on the north-west, the enclosed hollow of the Bajo del Gualicho from the Gulf of San Antonio. Its surface is very even. The gravel on it has formed a sort of conglomerate, and in spite of appearances, this gravelly soil is not bad for vegetation. It quickly absorbs the rain-water, which thus escapes evaporation. The vegetation is comparatively rich. There are no springs, but the autumn rains sustain manantiales in the marly surface, and these do not dry up until the spring. During the summer the plain is deserted, and there is no water. But the flocks return in the winter and remain there until spring. There is very little snow, as the temperature is moderate. In spite of the density of the pastoral population in winter, the pasturage is not injured. The grass grows plentifully amongst the thickets. This is because the flocks leave the district before the season when the grasses flower and reproduce, so the next generation is secured. 


\section{DEVELOPMENT IN THE SOUTH 149}

Part of the flocks which winter on the coastal plain pass the summer in the south-west, on the high basaltic tablelands of Somuncura. However, the whole of the surface of the tableland cannot be used permanently, or during the entire summer. There is plenty of water in spring, when the snows have melted. In the middle of the summer the flocks collect round the permanent springs, and they scatter once more over the mountain pastures during the autumn rains, before they return to the plain.

The second region is that of Valcheta. From Aguada Cecilia to Corral Chico the railway follows for sixty miles the edge of the outpour of lava from the south, which covers the Tertiary clays. In front of the basalt cliff the land dips in the north toward a closed depression, the Bajo de Valcheta, the bottom of which consists of clays impregnated with salt. Tertiary marine strata surround this hollow in the west and north, where they divide it from the Bajo del Gualicho, but here they form only a thin skin which covers the crystalline platform. The line of contact of the basalt and the Tertiary marls is marked by a series of good springs, and these give rise to permanent streams, such as the Arroyo Valcheta and the Nahuel Niyeu. At first they flow in a narrow valley crowned by basalts, with peaty prairies at the bottom, then over Tertiary marls, and, in the latitude of the railways, they pass into a gorge cut through the granites before losing themselves to the north in the salitral. A small agricultural oasis is sustained by the waters of the Valcheta.

The site of Valcheta has an exceptional importance in the story of Patagonian colonization. It marks a necessary stage in the Indian track from the Atlantic to Nahuel Huapi, which is now followed by the line of the railway. Musters halted there. The track from Choele Choel, on the Rio Negro, to the southern coast and the Santa Cruz also passed by there. It was so much used, says Ezcurra, that the hoofs of the horses 


\section{PATAGONIA AND SHEEP-REARING}

had hollowed it.I The Argentine village dates from I890. At first it lived by supplying fodder to the convoys of wagons which carried the wool. The railway has suppressed this traffic, and the only outlet of the oasis to-day is the small port of San Antonio, where the wool is shipped, and where the district is unsuitable for any kind of cultivation.

Like the coast region, the Valcheta district seems marked out by its moderate altitude to serve as winter pasture. In point of fact, it is used during the whole year. The springs do not dry up in summer. The streams which flow from the south toward the Bajo de Valcheta are permanent. In addition, a few wells have been bored in the Tertiary strata. Contrary to experience on the coast, therefore, cattle can be kept here during the summer. There is less chance for the grasses to reproduce, and the pasture tends to become impoverished.

The third zone, I30 miles from the coast, is that of the tableland of the Cerros Colorados, where low masses of red granite rise like an archipelago amongst the Tertiary formations deposited in the intervening depressions. In the west its altitude rises from 650 to $I, 300$ feet. It is one of the poorest parts of the tableland, and the size of the flock is reduced to 600 head to the square league. The naked rock crops up, not covered, as it is further east, by a bed of gravel. In the valleys there is little water, and it lies very deep. There are no periodical removals of the animals. Winter and summer they remain within range of a few poor springs, which are caused by various outcrops of lava of limited extent ; and they leave these, and wander over the tableland, only in the rainy season.

Beyond the Cerros Colorados the line rises rapidly, and at Maquinchao it reaches the basin of Lake Carilauf-

s Pedro Ezcurra, "Camino indio entre los rios Negro y Chubut: la travesia de Valcheta," Bol. Instit. Geog Argent., xix. 1898, pp. 134-38. 


\section{THE GREAT SHEEP-FARMS}

quen. This occupies the bottom of a closed depression, at an altitude of 3,000 feet, dominated on every side by a plateau of lava, toward which, in the south, a number of important valleys run (Nahuel Niyeu, Quetriquile, Maquinchao). These valleys rise in the south in the basalt plateau, at a height of 4,000 and 4,700 feet, and have no running water except at their upper ends. South of Carilaufquen they open upon a broad plain, round which there is a sombre cornice of lava, about 350 feet high. Water has collected on the plain, which consists of alluvial beds redistributed by wind : angular pebbles from the terraces, fine dust from the mallinas, and sand from the dunes round the lake.

This region is much better than that of the Cerros Colorados. There are many springs at the base of the lava-flows, on the sides of the valleys, and it has as yet not been necessary to look for the subterranean sheets which accompany some of the valleys. The elevated basin of the Quetriquile, though it is only occupied by intrusos, seems to have a particularly high pastoral density, and, I am told, feeds 500,000 sheep. In the western part of the region the spring is late, and there is risk of snow during the lambing season. There are, however, no rams there; the lambs are brought from Maquinchao. This arrangement of special zones for the multiplication of the flock enables them rapidly to improve the breed. Here again there are no removals of the animals to a great distance in order to use the pasture. The vegetation of the valleys suffered from the continuous presence of the flocks during the years of drought before I9I4; the reproduction of useful grasses was prevented. There is, however, less danger here than on the Cerros Colorados, because the mallinas are extensive, and they suffice for feeding the sheep during the periods when the manantiales of the tableland dry up, and the animals are confined to the valleys.

The fifth region comprises the high ridge which divides 


\section{PATAGONIA AND SHEEP-REARING}

the basin of the Carilaufquen from Nahuel Huapi, the water of which flows northward toward the Limay and southward toward the Chubut: successive eruptions have covered the surface with lava and ash, which at Añecon rise to a height of 6,700 feet. The granite platform which emerges in the north, at the Cerro Aspero and the Quadradito, rises to a height of 4,400 and 4,700 feet, and in some places presents a bold and rejuvenated aspect. The whole has been cut up in all directions by erosion, and it affords comparatively easy means of getting about, which the Indian tracks have followed. Below the higher slopes the valleys deepen into gorges, and these broaden out in the soft tufa and are lost at the cross-streams of lava or the outcrops of the granite. In so varied a land, with such marked differences of altitude, the winter and summer-pastures are always close together. Precipitation is more plentiful than at a distance from the Cordillera; the pasturage is richer, and the size of the flock rises to $r, 600$ sheep to the league. The sheep pass the winter on the lower slopes, where they are sheltered from the winds and the snow. They descend to the mallin when the dry season sets in and makes the soil firm. In summer they go on to the tablelands, where the pastures extend to a height of 5,000 feet.

Bailey Willis, studying the improvements that might be made in the pastoral processes, concluded that the essential point was to use each pasturage in its best season, and establish a carefully considered rotation on the various lands. This system, which alone would enable them to nurse the natural resources of the scrub in the way of plants for fodder, is used to-day in only a small number of districts-in the east, where the flocks winter on the coastal plain and spend the summer on the Somuncura tableland, and in the west, round the Añecon, where the summer and winter pastures are not far from each other. The custom 


\section{SUMMER AND WINTER PASTURE 153}

ought to be general. The area which ought to be reserved for winter pasture comprises the coastal plains, the whole of the low-lying district round Valcheta, and the lower part of the valleys to the south of the Carilaufquen. They are less extensive than the available summer pastures, but their capacity could be enlarged by developing the irrigated areas in the Bajo de Valcheta, and sowing lucerne in the mallinas of the basin of the Carilaufquen. The low valleys round the Carilaufquen ought to be reserved for winter pasture. In the summer the sheep would be taken south to the higher-level valleys, which afford permanent pasture. From there they would spread after the melting of the snow, and after the first rains in autumn, over the high tablelands which surround them.

This plan is obstructed in the first place by the actual terms of ownership, which were imprudently fixed before the examination of the country in detail had been concluded. Thus the Maquinchao ranch, in the lower valley, does not own the upper valley with the summer pastures that ought to belong to it. A more serious obstacle is that it is extremely difficult to remove the sheep. It is not merely roads that are wanting, but a water supply at the various stages. ${ }^{x}$

Between the railway that runs from San Antonio to Lake Nahuel Huapi and the Rio Negro, there is a desert region about seventy miles in width. Red sandstone predominates in it, and it remains uninhabited. North of this travesia the valley of the Rio Negro opens. Its width between Neuquen and Patagones ranges from five to fifteen miles. Its slope diminishes gradually toward the bottom (from 0.67 to 0.49 per $I, 000$ above Chelfaro; from 0.45 to 0.29 per I,000 above Conesa).

s The district of the Rio Negro is not the only part of Patagonia which faces the problem of increasing the winter pasture. Attention has been drawn to the possibility of enlarging the lucerne farms in the district of Colonia Sarmiento, south of Lake Musters, and making this a great wintering area for the Santa Cruz flocks. 


\section{PATAGONIA AND SHEEP-REARING}

The sandstone and marl cliffs which enclose it become gradually lower as one goes downward. They dominate the valley at a height of 650 feet at the confluence of the Neuquen, and are only Ioo to I30 feet high at Patagones. At the foot of them are broad terraces cut by dissymetrical ravines, in which the beds of sandstone outcrop on the western slope, exposed to the winds, while the eastern slopes are covered with gravel. On the banks of the river there is a strip about two miles wide with abundant herbaceous vegetation between lines of willows. This is covered by the normal floods. The remainder of the river plain, to the foot of the cliffs, has only a thin scrub, with dunes at intervals. Saline clays here overlie the river gravels. The level of the underground water, which is fed by the river, sinks lower as one goes from the banks toward the cliffs. Few parts of the tableland have so desolate an aspect as the bottom of these great Patagonian valleys, when they have not been transformed by irrigation. The pasturage is poor. At Conesa, however, the valley (costa) is used as summer pasture when there is a shortage of water on the surrounding tableland (planeza).

The water-supply is good, the volume of the river ranging from 200 to 900 cubic metres a second. Low water lasts from February to April (end of the summer). From May to July the river has sudden and violent floods-an effect of the autumn rains. The curve sinks again in August and September, to rise once more in October and December, when the snow melts on the Andes. The Limay, the upper basin of which contains large, lacustrine sheets, is more regular than the Neuquen, which has very pronounced low-water, as well as dangerous floods in the autumn. The first attempts at irrigation date from 1885 , when the canal of the Roca colony was dug. Others were made lower down at a later date. The co-operative groups organized for the administration of the canals have not been quite as successful as might have been expected. The 

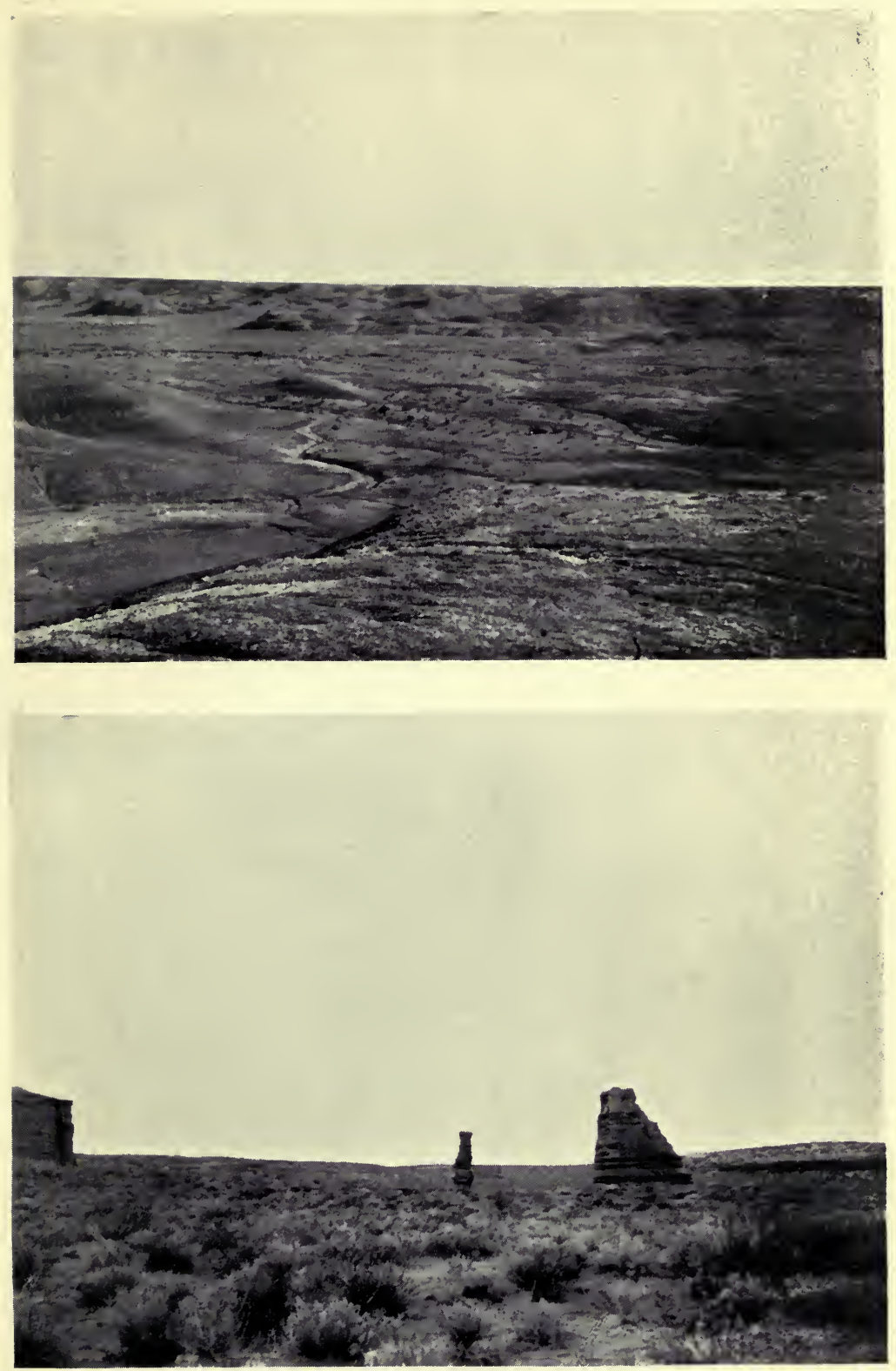

THE PATAGONIAN TABLELAND (NEUQUEN).

Indigenous vegetation. Rocks eroded by wind.

Photographs by Windhausen, Mining Division.

Plate XIV.

To face p. I54. 

advance of agricultural colonization has been slow. Costly preparatory work is needed to level the ground and organize the drainage, otherwise saline patches form and spread like leprosy at the expense of the cultivable areas. Lastly, the centre of the valley is exposed to floods. ${ }^{r}$

The chief crops are lucerne, cereals, and the vine. All the efforts and hopes of the colonists are now centred upon the vine. It is for the purpose of extending the vineyards that they are endeavouring to secure more workers. These are a singularly mixed lot, Chileans from the Neuquen rubbing shoulders with Latin immigrants (Italian and Spanish) from the region of the Pampas.

The lucerne is made up in bales and exported by rail to Bahía Blanca and Buenos Aires. The economic life of the agricultural oasis of the Rio Negro is no more connected with that of the pastoral tableland than is life on the Chubut. Neither sheep nor cattle are fattened on the Rio Negro. It is a curious contrast to the spectacle offered by the Andean regions of western and north-western Argentina, where for generations there has been a close association between the breeding industry of the scrub and the fattening on the lucernefarms. This is because the currents of the cattle-trade are not here as permanent and stable as they are in the north. The time when the convoys of Pampean cattle bound for Chile used the valley of the Rio Negro preceded the agricultural colonization of the banks of the river. The conquest of Patagonia put an end to this traffic. There was an interval of twenty-five years between the period of the export of Pampean

The work now (I9I4) in hand will reduce the risk of floods, and will enable them to enlarge considerably the extent of the tilled land. The Cuenca Vidal, which opens amongst the sandstone, below the level of the valley, on the tableland to the north of the Neuquen, will be arranged so as to absorb the flood-water, and it will feed a canal which will serve the left bank over an area of roo miles. The waters of the Limay will be available for the lower valley. 


\section{PATAGONIA AND SHEEP-REARING}

cattle to Chile and the export of cattle from the Neuquen to Buenos Aires, to which I will refer presently. As to sheep-breeding, it did not for a long time rear the animals for the meat-market, and it is only a few years since it found transport necessary. The farmers of the Rio Negro, who have little capital, and who sell and are paid in advance for their dry fodder, have not yet been able to take advantage of the reorganization of the cattle-trade.

West of the confluence of the Neuquen and the Limay the railway ascends the sandstone tableland, from $I, 700$ to 3,000 feet high, and goes as far as the foot of the first sub-Andean chain, the Zapala ranch. The eruptive rocks here have thrown up the sandstone, and the profiles raised north and south of Zapala, across the Sierra de la Vaca Muerta and the Cerro Lotena, cut through folds of Mesozoic strata which have been reduced by erosion to the level of the plateau. One already feels the vicinity of the Cordillera. Pasture is plentiful, the mallin is thick, and springs abound. The sheep-area stretches westward of Zapala, as far as the Rio Cataluin and the Rio Agrio. East of Zapala, on the other hand, the desolate condition of the country gets worse and worse. The supplies of water dry up in the summer, and the entire zone that lies east of $70^{\circ} \mathrm{W}$. long. is useless, on account of the lack of permanent water, except as winter commonage. Hence, transhumation is here indispensable. It has been practised for a long time on the Chilean slope of the Cordillera from the latitude of Coquimbo and San Juan to the north of Lake Quillen. At present it tends to disappear from the Andes of the Neuquen.I But there is still transhumation on

I As a matter of fact, of recent years there has been a practice on this slope of disguising the smuggling of animals under the name of " transhumation," as the removal of the sheep facilitated it and helped to maintain it. The shepherds got certificates exaggerating the number of their sheep from the Chilean officials before they crossed the frontier, and under cover of these they came back to Chile with additions to their flocks which they had bought on Argentine territory. 
the Argentine side. The sheep of the plateau, driven from their winter pasture when the water dries up, ascend the Cordillera. Sometimes the mountains are are not yet free from snow. In that case the journey is delayed, and the sheep feed on the way, to the great detriment of the land they cross.

There are many routes, and frequently they coincide with those which were formerly taken by the cattle of the Pampas in ascending to the passes of the Cordillera. Groeber mentions a transhumation track south of the Rio Barrancas and Lake Carri Lauquen. From the left bank of the Neuquen the flocks ascend by Chosmalal and Butamallin to the pasture of the Pichachen pass, or by Las Lajas to the Pino Hachado pass. From Zapala and the tableland further south they go to spend the summer in the Cataluin Cordillera, where the number of sheep in summer is calculated to be 70,000. Others go still further, to the source of the Alumine and the Arco pass. The volcano Lanin almost marks the southern limit of the zone of transhumation. The chief group of migrating sheep comes from the district of the Coyunco, the Cañadon Grande, and the Picun Leucu.

Transhumation is practised only by the intrusos. They go from the unowned lands of the tableland to the unowned lands of the Cordillera. The renting of winter pasture to owners is quite exceptional. The concessions of land granted by the Argentine Government are steadily reducing the area of the migrators in the Cordillera, and also the ways of communication between the tableland and the mountains. The proprietors do not care to receive the migrating flocks, and they put obstacles in their way by enclosing the land. The routes of the transhumation are now fixed by the spaces which remain open between the enclosed ranches. Moreover, the migrating intrusos are haunted by the fear of finding the winter pasture occupied by others during their absence, and they 


\section{PATAGONIA AND SHEEP-REARING}

have no proprietary title. The splitting up of the land and the organization of ownership will before long lead to the extinction of the practice of transhumation, and the greater part of the winter pasturage will be turned into permanent pasture by boring wells and nursing the water-supply.

The district round the Zapala ranch has become very busy since the construction of the railway, which has deeply affected the conditions of life there. It has made a sort of capital of Zapala. It is curious to contrast the renaissance which has followed upon the appearance of the railway in this district with the much less material changes which it has made at Maquinchao. The life which the railway concentrates at Zapala includes not only the wool trade, as at Maquinchao, but also the cattle trade. The herds which are to be exported gather round the ranch at the same time as the tropas of wagons, and a good price is paid for the right of pasturage. While the Maquinchao line ends at the port of San Antonio, which is merely fitted up for the export of wool, the Zapala railway feeds the refrigerator at Bahía Blanca. It joins up with the network of railways of the Pampa. Sheep arrive at Zapala, not only from the surrounding district and from the Neuquen, but from a good part of the Rio Negro, and even the Chubut. The convoys of animals coming from the south find it best to keep near the Cordillera, where the pasturage is better. Only a few of them descend the Limay as far as Senillosa. From Zapala to Senillosa there is no suitable road in connection with the railway, and further east it is necessary to go as far as Choele Choel to find tracks which lead to it. The exporting of the sheep lasts five months, from November to March.

Zapala station is also a point of convergence of herds of cattle. There are people at Zapala who still remember the time when the cattle brought from the Pampa to go to Chile passed through their valley. Although these 


\section{REVOLUTION IN CATTLE TRADE 159}

exports of Pampean cattle to Chile ceased after I885, the whole Andean region of the Neuquen still lived entirely on the Chilean market until very recently. The attraction of the Chilean market is one of the reasons for the survival of transhumation. It was to the advantage of the Argentine breeders to keep near the Cordillera and the passes through which the buyers came from Chile in the summer. The life of the small centres in the upper valleys which developed rapidly after the conquest (Chosmalal, Norquin, Codihue, Junin, and San Martin) was bound up with the Chilean cattle trade, and was reflected on the opposite side of the Andes in the prosperity of the corresponding markets in Chile.

In the years immediately preceding I9I4, a sudden revolution upset the cattle traffic on the Neuquen, and the attraction of Buenos Aires took the place of that of the Chilean market. The commercial influence of Buenos Aires was first felt in the wool-market. The tropas of wagons which brought wool to Zapala loaded up, in exchange, with the flour and salt that were needed for sheep-breeding in the pastures of the Cordillera (pastos dulces). The import trade followed the path traced by the export trade. The small Chilean wagons which still cross the Cordillera now only bring to the Neuquen the coarse flour of Chile, haricot beans, and wine. They return empty to Chile. After the woolbuyers, the cattle-merchants of Buenos Aires next found their way to the Cordillera. The centres where the sales of cattle for Chile used to be held are now in decay, and have lost part of their population. The cattle are sent to the fattening centres on the Pampa, or to the Bahía Blanca and Buenos Aires markets. Thus we have under our eyes, unexpectedly, in the north of Patagonia a transformation that occurred gradually half a century ago in all the western and north-western parts of Argentina. In its many forms it is the essential fact in the modern history of Argentine 


\section{PATAGONIA AND SHEEP-REARING}

colonization. The more distant provinces are detached in succession from foreign markets, and the whole national life is being organized round the great economic focus which the region of the Pampas has become. 
CHAPTER VI

\section{THE PLAIN OF THE PAMPAS}

The limits of the prairie-The rains-The wind and the formation of the clay of the Pampas-The wind and the contour-The zones of colonization on the Pampas-Hunting wild cattle and primitive breeding-The sheep-farms-The ranches-The region of "colonies" - The region of lucerne, maize, and wheatThe combination of agriculture and breeding-The economic mechanism of colonization-The exchanges between the different zones of the Pampas.

THE Pampean landscape is doubtless one of the most uniform in the world. Its monotony is tiring to the eye; it is partly responsible for the mediocrity of most of the descriptions of the Pampas. But this uniformity is an advantage for the purpose of colonization. Attention has often been drawn to the rapidity with which plants and animals introduced by Europeans spread in the Buenos Aires district, and, pushing ahead of the breeders and farmers, colonized the Pampas. In the second half of the nineteenth century, when the whole extent of the plain beyond the ancient Indian frontier was occupied, the development of it was so much easier because it was possible to use simpler and more uniform methods of exploitation. It needed neither large capital nor long personal experience on the part of the immigrant. Basques and Italians who had only just landed could take an active part in it almost without apprenticeship. The primitive groups of population could advance from one zone of the plain to another and take with them their own methods of farming and breeding, their own form of rural economy. 
A close study will, however, enable us to detect appreciable physical differences in the Pampean plain. Neither climate nor soil is the same all over it.

The name "Pampa" chiefly means a vegetal growth, a prairie. Its limits are the frontier of the scrub (monte), and strange as it may seem, it is still difficult to trace them exactly. North of Santa Fé, between the Salado and the Paraná, the Pampa stretches as far as Fives-Lille, a little beyond $30^{\circ} \mathrm{S}$. lat. ${ }^{\mathrm{I}}$ On the Central Norte and the Central Argentine lines the fringe of the monte reaches to Fuertin Inca and Malbran, about I7o miles north-west of Santa Fé. It then turns south-east and south, passing round the entire depression of Los Porongos and Mar Chiquita; and the line from Santa Fé to Córdoba crosses it at Francia and approaches the Rio Secundo. South of the Rio Secundo it goes westward and joins the foot of the Sierra de Córdoba south of the Rio Tercero (at the stream Tequia). From this point to La Cambre, some sixteen miles east of San Luis, the prairie extends as far as the edge of the sierras, and penetrates into the southern half of the Conlara depression, between the hills of Córdoba and of San Luis (Pampa de Naschel). The mimosa forest enters the steppe in narrow belts along the Rio Quinto to within a few leagues below Villa Mercedes, along the Rio Tercero as far as the confluence of the Saladillo, and along the Salado to the south of Santa Fé. There are, in addition, many isolated clumps of chañares and more extensive patches of wood in the north-west corner of the prairie (Santa Fé province). The monte along the Salado is continued south of Santa Fé along the Paraná, as far as the point where the chief arm of the river reaches the cliffs on

x On the left bank of the Salado, west of the Resistencia railway, a great gulf of low prairie penetrates into the forest of the Chaco in the north, almost as far as $28^{\circ} \mathrm{S}$. lat., but it has rather the character of one of the floodable clearings of the Chaco (esteros) than of the temperate Pampa. 


\section{THE SCRUB OF THE PAMPA 163}

the right bank, at San Lorenzo. This is the domain of the ombu, a tree with thick trunk and naked roots which is found scattered over the prairie in the Paraná region as far as south of Buenos Aires.

In the west, between San Luis and the mouth of the Colorado, the transition from the Pampa to the monte is gradual. Just as at Santa Fé, the approach of the monte is announced by the appearance of chanares, in the south-west corner of the Córdoba province and on the southern slope of the Sierra de la Ventana. The monte, properly so called, though impoverished, invaded by the jarilla, and mainly composed (as in northern Patagonia) of dwarf mimosas, covers the area of the Pampean sierras on the left bank of the Chadi Leuvu and the Colorado. Between this area and a line passing through Rancul, Anguil, Atreuco, and Bernasconi, where the naked prairie begins, there is a mixed zone which one may call the calden zone. This mimosa, a near relative of the algarroba, which has a wider range than the other plants of the monte in this latitude, forms woods at intervals in the south of the San Luis province and on the flanks of the parallel valleys of the central Pampa. Between these woods the tableland is generally covered by the prairie, with occasional patches of chañares. About twenty-five miles east of Buena Esperanza the line from San Rafael touches the far corner of a forest of caldenes, which stretches south-westward, and reaches the Rio Salado about $35^{\circ} 30^{\prime} \mathrm{S}$. lat. Beyond Buena Esperanza it keeps on the prairie as far as the crossing of the Salado, which here marks the limit of the monte. The Rio Negro line passes directly from the prairie to the Patagonian scrub mid-way between Bahía Blanca and the Colorado.

Within these limits the prairie extends without a break. The sierras of the Buenos Aires province have no arborescent vegetation.

The zone of the prairie, intermediate between tropical Argentina and the sub-desert regions of western 


\section{THE PLAIN OF THE PAMPAS}

Patagonia, has a medium rainfall. It decreases gradually from north-east to south-west. There is a rainfall of $I, 200$ to $I, 000$ millimetres on the lower Paraná, and only 400 to 600 millimetres on the western edge of the Pampa. The zone which lies between the 800 millimetres and 600 millimetres average is more than 270 miles in breadth. But what is most characteristic of the climate of the Pampa is the equal distribution of the rain throughout the year, and the absence of a real dry season. In this the Pampa differs from the surrounding regions, both in the south-west and the north. At Buenos Aires the six months of the (relatively) dry season yield, nevertheless, 44 per cent. of the total rainfall, and at Bahía Blanca 40 per cent. This regularity diminishes in proportion as one approaches the coast. At Rosario the six months of the dry season only yield 30 per cent. of the year's rain; at Villa Mercedes (San Luis province) 25 per cent. When one goes beyond the limits of the prairies the ratio of rain in the dry season decreases rapidly; it is only 20 per cent. at Córdoba and 18 per cent. at San Luis. At Córdoba, the curve of the rainfall indicates a typical tropical regime, with a summer maximum and a very low minimum in winter. Passing south-eastward from Córdoba, at Bellville, Villa Maria and especially Rosario, the dryness of the winter diminishes, and at the same time a secondary minimum appears in the middle of summer (January-February). At Buenos Aires, the form of the curve changes completely. The summer minimum is almost as low as the winter minimum, and most of the rainfall is in the spring (September) and the beginning of the autumn (March). ${ }^{\mathbf{I}}$

I Argentine Mesopotamia, which is a continuation of the Pampean region from the climatological point of view, is also, even in its northern part, without the rigorous dry seasons of the Chaco. Ascending the Paraná, from Corrientes to Posadas, just as in passing from Córdoba to Buenos Aires, one notices that the winter minimum decreases, 


\section{THE CONTOUR OF THE PLAIN 165}

These various shades of the Pampean climate are of essential importance in the history of colonization and the spread of cultivation. The belt of summer rain is the belt of maize-growing, whereas the cultivation of wheat requires spring rain and a comparatively dry summer.

While the isohyetic curves, which represent the precipitation for the whole year, are orientated from north-west to south-east, the curves of rainfall during the cold season, from April to September (dry season in the north), cut diagonally across the preceding, and are oriented directly north and south. Bahía Blanca receives in winter as much rain as Rosario, and General Acha (in the district of the central Pampa) as much as Córdoba. Unless one attends to this, one cannot explain the extension of wheat-growing, in the southwest, as far as the 400 millimetre curve, and even beyond it on the Atlantic coast.

The relief of the Pampean plain is known fairly accurately, thanks to the observations made along the railways. The ground rises slowly toward the west. The Ioo-metre curve describes a deep gulf some 300 miles west-south-west of Buenos Aires. The belt comprised between Ioo and I5O metres above sealevel is more than sixty miles broad in the latitude of Santa Fé, and I30 miles in the latitude of Buenos Aires. Beyond the I50-metre curve the land rises rapidly toward the west and north-west, and reaches 400 metres in the Córdoba district and 500 in the Villa Mercedes district. It is at the altitude of $\mathrm{I}_{50}$ metres, and the break in the inclination which this marks, that the Rio Quinto is lost, near Amarga, south of General Lavalle.

and a secondary maximum appears in the spring. The predominance of the spring rains, which is a characteristic of southern Brazil, is conspicuous on the middle Uruguay. On the lower part of that river the rain-system approaches that of Buenos Aires, with maxima in spring and autumn, a principal minimum in winter, and a secondary minimum in summer. 


\section{6}

\section{THE PLAIN OF THE PAMPAS}

The ridge between the Pampa and the basin of the Salado in the south of the San Luis province is about 450 metres above sea-level. South of the province of Buenos Aires the Sierras de Tandil and de la Ventana are joined together by a ridge which does not fall below 200 metres. Certain irregularities of the surface, such as the depression of Mar Chiquita to the east of Córdoba, the thrust of the plateau on the right bank of the Paraná, south of Villa Constitución and San Nicolas, can, apparently, only be explained by recent tectonic movements.

The Pampean deposits which cover the plain rest upon a rocky base of which the salient representatives are the sierras of the province of Buenos Aires and the hills at Córdoba and San Luis. This base also appears east of the Pampean basin in the granite island of Martin Garcia, in the middle of the estuary of the Plata, and in the hills on the coast of Uruguay. ${ }^{x}$

Underneath the even sheet of the alluvial deposits the surface of the sub-Pampean platform is very irregular. Its shape has been discovered by deep borings in search of arterial waters. It has been warped and cut up by faults, some of these deformations being probably synchronous with the formation of the Pampean deposits which have concealed them as they have been produced. A subterranean rocky ridge continues the Sierra de Córdoba southward and joins it with the sierras of the Colorado. The granite emerges at Chamaico, on the western railway, and on both sides the borings have passed through great depths of clay and sand.2 This ridge isolates the eastern Pampa from

I While the Pampean deposits lie immediately on the crystalline and Paleozoic formations in the sierras of the lower Colorado and of the central Pampa, in the south of the province of Buenos Aires and in Uruguay, they are, on the eastern edge of the Sierra de Córdoba, separated from it by red sandstones and conglomerates of uncertain age, perhaps synchronous with the continental red sandstones of Corrientes which outcrop east of the Parana and have been known since D'Orbigny's time as "granitic sandstones."

2 At Rancul, in the east, 660 feet of loess overlying red sandstone : at Telen, in the west, 2,800 feet of sand, marl, sandstone and gravel. 


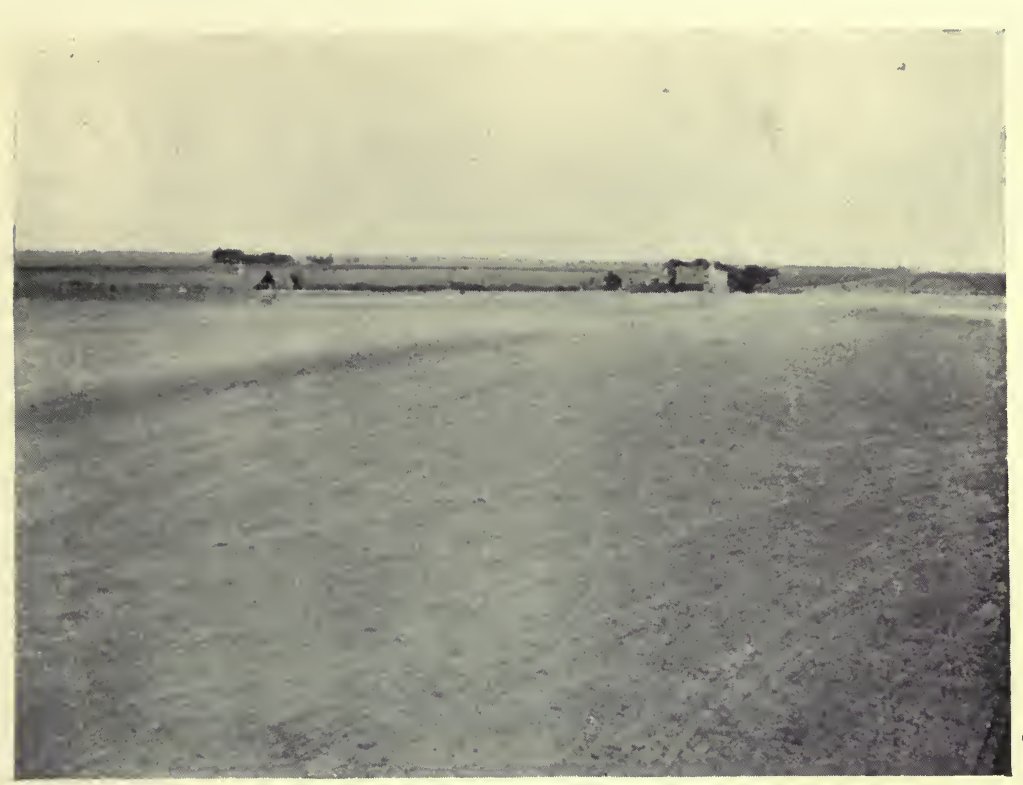

THE PAMPEAN PLAIN. TRES ARROYES (BUENOS AIRES PRAIRIE BETWEEN THE SIERRA DE TANDIL AND THE SIERRA DE LA VENTANA).

Zone of wheat and oats on large scale. The Pampa is a tableland here (400 feet above sea-level), with clay overlying the limestone of the Tosca. The valleys are well marked.

Photograph by the Author.

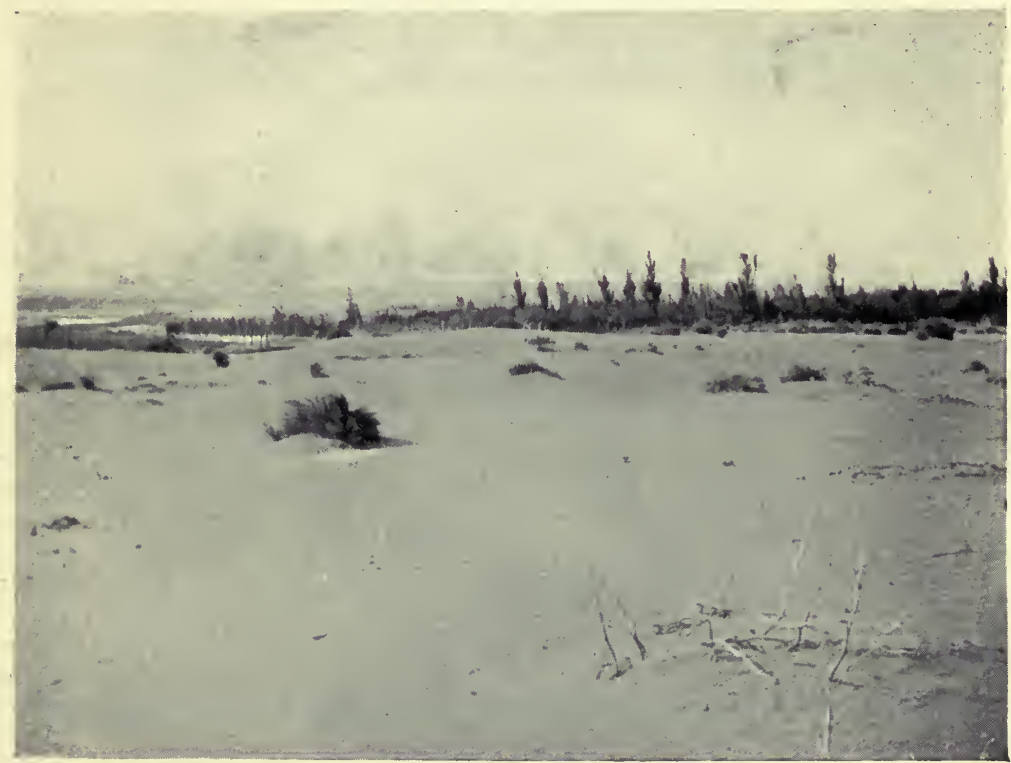

THE PAMPEAN PLAIN. TOAY, ON THE CENTRAL PAMPA (J9O FEET).

The tableland, with a strong framework of limestone Tosca, is cut across by well-marked dry valleys which sink lower toward the east. At the edges of the valleys the sand is the prey of the winds. Here we are near the limit of the wheat belt. Photograph by the Author. PLATE XV.

To face p. 166 . 

the sub-Andean chains, and marks the limit of the area with sheets of underground water. In the north of the Pampean region, between the Sierra de Córdoba and the Paraná, the loose continental formations are more than 2,000 feet thick at Bellville, and more than 3,500 feet north-west of Santa Fé (fodder farms of San Cristobal and El Tostado). At Buenos Aires the granite has been found 985 feet below the surface.

The Pampean formation consists almost entirely of loose deposits, sand and clays of various sorts. There is no gravel. ${ }^{1}$ Even in the vicinity of the sierras the beds of gravel, with round or angular pebbles, are almost always covered by clay, and are exposed only in the banks of the streams. Olascoaga mentions the surprise of the gauchos of General Roca's army when they found Patagonian pebbles on the ground during their stay at Choele Choel on the Colorado, in the course of the compaign on the Rio Negro. Officers and soldiers dismounted to pick them up. Sand and clay form a thick bed of continental alluvia. The Tertiary maritime transgressions, which have left their mark in the clays and limestones of the left bank of the lower Paraná, and the layers of shells at San Pedro on the right bank, never penetrated far into the interior of the Pampean region, and one finds no trace of them when one leaves the coast or the river.

The source of the elements which compose the Pampean alluvia is very uncertain. Their composition does not clearly show their origin. The clays are comparatively rich in calcareous matter, which seems to indicate that they do not come from tropical America or the upper basin of the Paraná. Wright and Fenner insist upon the high proportion of siliceous glass of volcanic origin which they contain, which points to

Roth claims to have found gravel in the San Nicolas barranca on the Paraná. I have myself found small rounded flints in the clay of the Chaco at Tartagal. But these deposits probably come from the left bank of the Paraná, where the beds of river gravel are considerable. 


\section{THE PLAIN OF THE PAMPAS}

an intense eruptive activity during or before their formation. I Doering had already noticed in the Córdoba region the prevalence of beds of volcanic ash, which become thicker as one approaches the sierra. It is certain that the Pampean sierras have had their share in the formation of the Pampean beds. But the main mass is probably of Andean origin. However that may be, as soon as one gets away from the fringe of the mountains, the only variety noticeable in the lands of the Pampa is that which they owe to the conditions in which they have been deposited.

River deposits strictly so called, estuary deposits, lagoon deposits, æolian deposits, æolian deposits redistributed by water, river deposits redistributed by wind-all these different types are represented in the Pampean formation, but their relative importance is still disputed.2

I In Ales Hrdlicka, Early Man in South America (Smithsonian Instit. Bull., 52, Washington, I912).

2 Many attempts have been made to classify the Pampean lands, but the results cannot be regarded as final. Ameghino, who is first and foremost a palæontologist, has done a service in showing the futility of these geological divisions based upon the actual surface of the deposits (colour, fineness, etc.). But even palæontology gives rather uncertain results, as it is impossible to recognize and follow step by step the various stages of the movement of the fossils. All the classifications of the Pampean are based upon a study of two groups of sections. The first group comprises the cliff on the right bank of the Paraná from Rosario to Buenos Aires and the coastal cliff which is a continuation of it, with a break from Enseñada at Mar Chiquita to Bahía Blanca. Ameghino has recognized there a thick series of æolian deposits separated by several discordances, the oldest elements of which, at Bahía Blanca, belong to the Miocene. The second group comprises the cliffs which enclose the valley of the Rio Primero above and below Córdoba. Doering and Bodenbender in this case describe two stages of æolian loess, each covered by torrential gravel.

From the study of these sections geologists have drawn certain conclusions as to the movements which have affected the soil of the Pampa and the changes which the climate has experienced. These conclusions have in each case only a local value, and they have not yet been co-ordinated. The majority of the observers, from Doering to Bailey Willis and Rovereto, seem not to have taken into account sufficiently the fact that in the continental formations the most diverse 
When we confine ourselves to studying the actual conditions in which the deposits were formed, we are first struck by the poverty of the hydrographic network of the Pampa. It is slight except in the vicinity of the sierras, where the slope of the ground is pronounced, and in the eastern area, on the right bank of the Paraná and Entre Rios, where the climate is more humid, and the streams flowing over an impermeable soil more numerous. The only one of the streams born in the Pampean sierras that reaches the Parana is the Rio Tercero or Carcaraña. All the others dwindle as they descend, and disappear in a low-lying district marked by lagoons which they only reach in time of flood. The floods themselves never bring the Rio Cuarto and the Rio Quinto and the Salado de Buenos Aires into touch with each other. The waters of the northern slope of the Sierra de Tandil, and even those of the Sierra de Curumalal, on the other hand, reach the Salado after the rains, either by way of streams which drain the strings of lagoons, or by flood-sheets, which spread over large areas.

The watercourses of the plain are unstable in their direction. The traces of their wanderings remain in the form of stretches of alluvial sand crossing the fine æolian clays. These river sands sometimes spread over extensive areas, the distribution depending upon a hydrographic scheme which is now partially effaced. The sands of the departments of General Lopez (south of the Santa Fé province) and General Arenales (Buenos Aires province), where the Salado is now developed, were probably brought by the Rio Cuarto, and mark an earlier junction of the Cuarto and the Salado. These sands run along the Salado as far as the confluence of the Saladillo, and the contrast between the light soil and the clay of the bank of the Parana is so

deposits may come next to each other in the same series, according to the particular process of deposition, and that their alternation does not imply a general change in the conditions of erosion. 


\section{THE PLAIN OF THE PAMPAS}

striking that the sand has long been regarded as a marine deposit, indicating an ancient shore. Along the Saladillo also, north-west of the Guamini lagoons, there is a sandy belt which corresponds with an important direction taken by the actual flow of the river, crossing the Bolivar and Veinte Cinco de Mayo departments.

While the agency of running water in transporting alluvia is confined to certain sections of the plain, the action of the wind is seen over its entire surface. The wind everywhere supplements or replaces running water. Like running water, it classifies the elements it conveys, and selects them according to their weight and size, the finest clays being deposited in the moist eastern zone and the coarsest sands in the sub-desert zone of the west. The mechanism of erosion explains this contrast. The grains of sand that are driven by the wind travel at the surface of the ground as long as the vegetation is too sparse to fix them. If one goes further east, to a moister district with a thicker vegetal carpet, the grains of sand no longer move at the surface of the ground, but the wind still carries fine particles of clay, which it bears to a great height. The bed of clay does not at all imply an arid climate, as is said sometimes, but corresponds to the region of the steppes, with moderate rainfall. It is, however, during dry seasons that the deposition of clay is at its greatest. Darwin mentions that after the droughts of $1827-1830$ in the area round the Paraná, the marks were buried under dust to such an extent that one could no longer recognize the limits of the various lands. Apart, however, from these sorts of floods or storms of dust caused by the pampero, the summer atmosphere is clearly laden with dust, which colours the skies in the east of the Buenos Aires province, as far as Entre Rios.

The contour of the plain bears, like the soil, the double marks of erosion by running water and æolian erosion. The rivers of the Pampa, when they leave the sierras, 
flow between high cliffs, the height diminishing as one goes downward. Presently these barrancas become low, approach each other, and at last merely mark the banks of a larger bed which the floods fill. There is no trace of valleys. Bailey Willis, surprised at this weakness of watercourses that have, nevertheless, an appreciable fall, attributes it to the fact that the cycle of erosion opened by the last upheaval of the Pampa has not yet had time to penetrate into the interior. In reality, it means that here we are at the limit of the zone of erosion by running water, and that in this climate the essential factor in shaping the landscape is the wind.

The region of the right bank of the Paraná (east of the Salado), which alone has a complete hydrographic network, must be considered apart. From the latitude of Rosario to that of Buenos Aires it is cut by flatbottomed valleys which are sometimes a hundred feet deep. The excavation of these valleys is due to an upheaval which raised this part of the Pampa above the base-level. The rapids of the lower Carcaraña also bear witness to this resumption of excavation. Farther on an inverse movement has put the bottom of the valleys below this level, and led to their being filled up (lagoon deposits of the Lujanense of Ameghino). South of Buenos Aires the upheaval has been less important, and the valleys are not so deep. Some of them (middle Salado and its tributaries on the left bank) are now occupied by long lagoons with steep banks, branching along the side-valleys, and these owe their origin to the same negative movement, subsequent to the excavation of the valleys. The upheaval did not extend to the eastern part of the province of Buenos Aires south of the Salado, a low-lying flat area, badly drained, exposed to floods, the contour of which has been minutely studied in connection with the construction of a great network of drainage-canals. North of Rosario, on the only slightly permeable clay, the water circulates, after rain, not by means of valleys in the proper sense, 
but along broad and almost imperceptible depressions (cañadas) where the current is slow, and the water dries up in the dry season. Their general relations are not yet known.

The loose deposits of the Pampean offer little resistance to erosion. The cycles are run through rapidly, and the traces of earlier cycles are faint, and are soon effaced. ${ }^{1}$

An ancient erosion-surface, dissected by the existing valleys, has survived in the south-west of the Pampean plain, thanks to the presence on the surface of a sheet of hard limestone, the tosca. The tosca is the result of the concentration of calcareous elements contained in clay at the surface in a dry climate. The formation of it implies a prolonged stability of the surface on which it has accumulated. Like the deep decomposition-soils in moister regions, it indicates a peneplain on which erosion has ceased. The bed of tosca covers the whole district between the Sierra de Tandil and the Sierra de la Ventana, the south-western slope of the Ventana, and most of the area of the central Pampa. In the north it does not go beyond the line from Buenos Aires to San Rafael. Its eastern limit goes almost by Ingeniero Malmen, Monte Nievas, and Atreuco, where it joins the southern bank of the lagoons of Carhue and Guamini in the east. ${ }^{2}$ In some places the tosca is about forty feet thick.

To-day the region of the tosca forms a plateau cut by narrow valleys, sometimes 200 feet deep, west of the Sierra de la Ventana and in the central Pampa. These

- Certain features of the hydrographic network clearly have the character of having been superimposed: that is to say, the path of the watercourses has been bequeathed to the actual plain by former erosion-surfaces, which have now disappeared, on which the valleys were originally imposed. That is why in the district of the confluence of the Colorado and the Chadi-Leuvu the valleys pass from Pampean deposits to the crystalline sierras, which were at one time entirely covered with water.

2 In the vicinity of San Luis and Córdoba the hard strata which are called tosca are beds of eruptive ashes. 


\section{SCULPTURE BY WIND}

parallel valleys, with few ramifications, generally lying south-west to north-east, open to the east upon the Pampean plain about the frontier of the Buenos Aires province. On the other hand, the southernmost of them begin at the foot of the Ventana, and seem to blend in the south-west with a general depression that is still little known, though it appears to end at the bottom of the estuary of Bahía Blanca. None of them has permanent running water. $x$ The origin of the dry valleys of the tosca is one of the most obscure problems of the morphology of the Pampean plain. Perhaps they are due to æolian erosion, like the depressions which are found on the plateau of the Colorado and the Rio Negro further south.

The action of the wind in shaping the landscape is more clearly seen in the formation of the dunes. When one starts from Buenos Aires or Rosario, and gets beyond the region of the level Pampas, the dunes are the first feature to meet the eye on the surface of the plain. The first fresh dunes are encountered at Carlota, on the line from the Rio Cuarto ; at Lavalle on the line from Villa Mercedes; and at Trenque Lauquen on the line from Toay. The dunes spread northward as far as the latitude of Mar Chiquita, but do not enter the Chaco. They are also found in parts of the scrub on the west, but their proper domain is the western border of the steppe, the upper part of the plain at the foot of the Sierra de Cordoba, the south of the San Luis province, and the central Pampa.

Any accident that causes the vegetal covering to disappear, such as the tread of cattle near a drinking place or an enclosure, is enough to set æolian erosion at work. The wind raises the sand in a sort of tossing sea. Then the dune assumes a circular shape. A

I The surface of the tosca tableland is further punctuated by a great number of closed depressions of various depths: long tunnels (dolines) which can only be explained, apparently, as an effect of the dissolving of the limestone by water. 


\section{THE PLAIN OF THE PAMPAS}

depression appears in the centre, and it deepens until it reaches the average level of the plain. Frequently there is a little lake in it. From this point onward the deformations are less rapid. The vegetation again creeps over the ground, and the dune falls a prey to the rains, which slowly reduce its mass.

In the central Pampa, where the elevation is considerable, the dunes do not form separate circular patches, but stretch in lines parallel to the valleys-sometimes in the heart of the valley, at other times backing against one of its slopes.

Far to the east of the zone of the quick dunes, in the south of the Córdoba province and the centre of the Buenos Aires province, there are certain soft undulations, covered with vegetation, with a sandier soil than that of the plain around them. These are dead dunes. The district of the dead dunes is characterized by the extreme irregularity of the surface-soil, the humus, which gains in richness and depth, as a general rule, as one goes eastward, because there it is in some places covered by recent æolian deposits.

The distribution of the dead dunes is connected with the stretches of river sand across the Pampa, which have offered an easy victim to the winds. A line of dead dunes follows the upper course of the Salado in the district of Junin and Bragado. On the line from Buenos Aires to San Luis one crosses it between Chacabuco and Vedia, and then one comes again upon the horizontal plain, which has fresh dunes, only further west, at I20 miles from Villa Mercedes. Its elevation is so conspicuous on the level plain that the first breeders who used its pasturage gave it the emphatic name of the cerillada. D'Azara correctly appreciated the nature of it. "It is, " he says, " only a dune of very fine sand." It is only a few yards high. The dead dunes of the Bolivar and Veinte Cinco de Mayo departments, which Parchappe described, have a more conspicuous relief, and in their disposition sometimes 
remind us of the fresh circular dunes with a central lagoon. The lines of coastal dunes in the eastern part of the Buenos Aires province obstruct the proper flow of the water there, and form a group apart, which must be clearly distinguished from the dunes on the plain. ${ }^{x}$

Thus the impression of monotony which the Pampa makes in us is corrected to some extent by close observation. High and low land alternate on it. Parchappe himself had noticed the contrast between the area that stretches from Buenos Aires to the Salado, with its soft undulations and its well-developed hydrographic network, the horizontal plains on the right bank of the Salado, with their irregular dunes, and the southern plateau of the tosca between the Sierra de Tandil and the Sierra de la Ventana.

We may now distinguish the following regions in the Pampa as a whole:

I. The central part of the Santa Fé province forms what is called the district of the "colonies": that is to say, the domain of the colonies established two generations ago, and the zone in which the type of cultivation introduced by them took root. The chief crops here are wheat and flax. Hedges of service trees (paraisos) surround the fields. In contrast with the parts of the Pampa which have remained naked, the region of the colonies seems a veritable grove. It

I Outside the districts with quick and dead dunes, a frequent type of landscape on the Pampa. is a plain thinly sown with very small lagoons, generally circular, between which develop a series of barely perceptible undulations. The inequality is at times so slight that one only notices it by the contrast between the vegetation of the lower and the higher ground. This type of landscape, which is especially seen in the district of Lincoln or of Nueve de Julio, is due to the action of the wind on a plain where the level of the underground water is near the surface. This level marks a limit below which æolian erosion does not take place : a sort of base-level. The periodic variations of level of the underground water reduce or enlarges the undulations of the surface. 


\section{THE PLAIN OF THE PAMPAS}

stretches westward beyond the frontier of the Córdoba province, and it reaches the fringe of the monte between San Francisco and Mar Chiquita. For the north, Miatellogives $30^{\circ} \mathrm{S}$. lat. as the normal limit of the wheatgrowing area; beyond this it suffers both from the low rainfall of winter and the excessive rainfall in summer. As a matter of fact, the large estates only reach this latitude on the line from San Francisco to Ceres. On the Resistencia line, north of Santa Fé, they stop at $30^{\circ} 30^{\prime} \mathrm{S}$. lat. In the intervening district the limit of the region of the colonies almost coincides with that of the department of Castellanos, about $30^{\circ} 45^{\prime} \mathrm{S}$. lat. The area lying between this line and the northern edge of the Pampa is given up to breeding. In the south the region of the colonies stretches as far as Las Bandurias and Irigoyen.

2. South of the region of the colonies, the tableland on the right bank of the Paraná, west of Rosario and San Nicolas, is the maize region, the corn belt of Argentina. Flax is generally cultivated as well as maize. It is the agricultural country par excellence of Argentina. The soil, of fine clay, dark red in colour and retentive of moisture, and the abundant summer rains, are very suitable for maize. The limits of the maize region describe an arc of a circle round Rosario with a radius of 60 to Ioo miles. They do not quite reach the frontier of Córdoba in the west, and they leave out the entire south-western corner of the Santa Fé province. The maize belt touches the Paraná between $32^{\circ} \mathrm{S}$. lat. and the Baradero. In the north it passes suddenly into the region of the colonies. In the south, on the other hand, there is at the edge of the corn belt an extensive transition-area, where maize and wheat occupy pretty much the same surface; it stretches as far as the Rio Salado de Buenos Aires.

3. The region of the lucerne farms is much larger. It comprises the whole north-west corner of the Buenos Aires province, from the Salado, in the district of Junin, 
to the southern limit of the Nueve de Julio and Pehuajo departments, and as far as the latitude of Guamini. The limit of the lucerne farms does not include the lands of the central Pampa, but advances westward and takes in part of the Pedernera department in the San Luis province. The lucerne farms run along the San Rafael line to Batavia, and at this point they reach the limits of the colonized zone. In addition, the zone of the lucerne farms includes the whole south-eastern part of the Córdoba province, as high up as the line from Villa Mercedes to Villa Maria, and the southern part of the Santa Fé province. In the whole of this area, fifteen to twenty-five per cent. of the surface is planted with lucerne. The conditions required for its cultivation are a moderate depth of the underground water and a light soil that allows the roots to penetrate easily. The eastern belt of clays is not good for lucerne, which survives there for much less time than in the west, where it may live fifteen or twenty years.

The lucerne belt is above all a great breeding area for horned cattle, as sheep-pasturage injures the lucerne. It is not nearly so monotonous, however, as the preceding regions. In the south-east, in the Buenos Aires province, the creation of the lucerne farms was undertaken at a time when agricultural colonization had already begun. We therefore find two types of exploitation side by side. The cultivation of maize enters it in the south-west, in spite of the comparatively unfavourable climatic conditions. The centre of the lucerne area in the south of the Córdoba province is also a great agricultural zone; but there agriculture is directly connected with the creation of the lucerne estates. It is, in fact, entrusted to colonists who till the ground for four or five years, and restore it to the owners sown with lucerne at the expiration of their lease. The crops consist almost exclusively of wheat and flax. Lastly, in the west (San Luis province 


\section{THE PLAIN OF THE PAMPAS}

and extreme south-west of Córdoba province) the soil gets increasingly more sandy, and the climate drier. A single tillage suffices to destroy the natural vegetation and clear the place for lucerne. The lucerne fields have been created by the breeders themselves, the sole masters of the region, without the aid of the colonists.

4. Beyond the lucerne belt, at the point where the plain rises toward the Sierra de San Luis and the Sierra de Córdoba, the subterranean water sinks deeper. This zone at the foot of the ranges, unsuitable for lucerne, yet with a soil comparatively rich in humus, has been taken up by agricultural workers. The wheat area extends, in the San Luis province, as far as Fraga and Naschel, in the Conlara depression. The maize area extends to Oncativo, in the Córdoba province, between the Tercero and Secundo rivers, where the summer rainfall is heavier. Thanks to the nearness of the mountains, this area has a water-supply for irrigation, and this sustains several small centres of good farms.

5. The south of the Buenos Aires province and the central Pampa are the wheat zone. The bed of tosca, which is not far below the soil, does no harm to the wheat except in years of drought. The valleys, where the tosca is interrupted, and the dunes, where the soil is deep, are very carefully used for lucerne fields of limited extent. Wheat-growing seems now, both in this and the preceding zone, to have reached its limit, as the dryness makes it improbable that there will be any extension westward.

6. Lastly, the east of the Buenos Aires province, the centre of which is fairly indicated by the little town of Dolores, is the only part of the Pampean plain which has not been reached by agricultural colonization. The land lies low, and is badly drained. The only change that has taken place in the vegetation is a progressive improvement due to the hoofs of the cattle during their long stays there. This pastoral area is 


\section{THE WILD CATTLE}

clearly limited in the south by the Sierra de Tandil. In the north it is continued in the more varied region that lies between Buenos Aires and the lower Salado, where the alternation of winter pasture on the dry lands and summer pasture in the valleys, encourages the best methods of breeding, and has made it the region of the dairy industry.

In the Entre Rios province the limit of the large estates of wheat and flax is marked by $32^{\circ} \mathrm{S}$. lat. The part of Entre Rios which extends north of $32^{\circ}$ and the Corrientes province do not strictly belong to the Pampean region.

Extensive breeding was the first form taken by white colonization on the Pampa. The word breeding is, in fact, hardly the correct name for an industry that mainly consisted of hunting, and was wholly distinct from the patient and advanced methods used at the same time in the northern provinces.

"The real wealth of the province of Buenos Aires," says Dean Funes, "was, and always will be, the trade in hides" (la pelleteria). I A good part of the hides exported came from the hunting of the wild cattle and horses which had grown numerous on the area of the Pampa beyond the Rio Salado. ${ }^{2}$ It was mainly after I778, when trade with Spain had been authorized and there was an increased demand for hides, that the hunting of these ownerless beasts was taken up. Two thousand Spaniards from Buenos Aires, Santa Fé and

- Ensayo de la historia civil del Paraguay, Buenos Aires, y Tucumán (3 vols. in $16 \mathrm{mo}$, Buenos Aires, 1816, t. iii, p. 214.

- The number of wild animals and the area over which they roamed have often been exaggerated. It does not look as if they ever covered the whole of the Pampean plain. A salter who crossed Patagonia and the whole of the Pampa in 1753 (Voyage du San Martin au fort de San Julian, Coll. de Angelis, v.) only found wild herds near the Salado frontier, and he knew by this that he was close to the ranches. At the beginning of the nineteenth century there were no wild cattle left on the right bank of the Paraná. There were still some in Entre Rios. 


\section{THE PLAIN OF THE PAMPAS}

Mendoza hunted every day, says D'Azara, killing an animal for each of their meals in addition to those they killed for hides. From I775 to the Revolution, the Spanish Government made continuous efforts to regulate and reduce the massacre of the herds. It laid down penalties for every person selling hides that did not bear his own mark; it farmed out the right to hunt animals with no mark, and organized the destruction of wild dogs, etc. The ranches developed under shelter of this legislation. Still, the Revolution did not witness the end of this cattle-hunting. D'Orbigny took part in I828 in two hunts of wild horses (baguales) in Entre Rios. The Argentine gaucho long retained the ways of a hunter rather than those of a breeder in the strict sense ; witness Urquiza's soldiers who, says Demersay, during the campaign of 1846 , when they could not find trees to which they could fasten their horses, killed cattle and tied the reins to their horns.

Passing from the hunting country to the zone of ranches, one notices that the main work of the breeder is to prevent his cattle from running wild. "The ranches of this country," said Dean Funes, "having been set up on immense plains, on which it was not easy to confine the herds within fixed limits, it sometimes happened that the animals went vast distances in search of water or pasture, and ended by being regarded as wild and ownerless." When D'Azara wants to show that the ranches of Paraguay are superior to those of Buenos Aires, he is content to say that there the animals are tamer (mansos). With the wild animal (alzado) is contrasted the de rodeo animal: that is to say, the cattle which are rounded up periodically in the centre of the ranch to be taken to the pasture where they must live (aquerenciar). It is the difficulty of preventing the dispersal of the herd that fixes the price of the rincones (surrounded by inundated areas) of Corrientes, in which the animals are captives.

MacKann's description of pastoral life in the Buenos 
Aires province in the middle of the nineteenth century give us a very clear impression of the stage of transition between exploiting the natural increase of a herd that multiplies without man's intervention, and breeding in the strict sense. The value of a horse in the former case is almost exclusively the cost of breaking it in. The breeder is actually anxious when he sees his horses increase, as he fears he may not have the resources for breaking them in. The most formidable of the dangers that threatened the feeble discipline of the herd was drought. That in the year I827 was a disaster. The animals left the ranches in a body to go southward, where they mixed. ${ }^{\mathrm{x}}$

I The water problem is not as important for the history of colonization in the Pampean region as in the north. Primitive breeding was confined to natural supplies of water, lagoons or streams, and to shallow wells (jagueles) dug down to the superficial sheet, which is generally not deep, but is liable to dry up. As colonization improved, the breeder, and subsequently the farmer, were better equipped for boring wells, and no longer feared drought. They got down to the deeper waters, semi-artesian (Buenos Aires district) or artesian (west of the Santa Fé province, round San Francisco). In other places the superficial waters, which are fresher than the deeper layers, were used by adapting new types of filters to the wells (Buena Esperanza district). The only two districts where the quest of water offered any difficulty are the south-west corner of the Pampean region and the northern extremity of the prairie in the Sante Fe province. The sheets of water are very irregular there, often saline, and it was a long time before the ranches got an assured supply.

One remarkable circumstance is the importance of the dunes in connection with the distribution of the underground water. The rain-water accumulates in the dunes and flows slowly through the sand to the sub-soil. The level of the underground sheet in the clay on which the dune rests is always nearer the surface in the neighbourhood of the dune. The dune itself has often a greener vegetation than the land around it. Nothing is more surprising than to find at Medanos (west of Bahla Blanca), in the middle of a plain of arid aspect, fields of lucerne and orchards lodged in the hollows of dunes that are still fresh. In the whole of the Buenos Aires province the dead district of the dunes is, on account of its water-supply, a good place for habitation. D'Azara notices the numerous water-spots which ran along the foot of the dead dunes of the Cerillada. All round were the white bones of the baguales. In the valleys of the central Pampa, where the sheet of water in the centre of the valley is often saline, the underground water improves gradually as one approaches the line of the dunes. 


\section{THE PLAIN OF THE PAMPAS}

Revolutions and wars interrupted the work of taming the cattle. When Galvez went from the Córdoba province to Buenos Aires at the end of the Rosas Government, he was struck by the condition of the ranches. I Many of them had been confiscated, or their owners driven into exile. Cattle were no longer marked, and they had become wild. The troubles of the emancipation-period were much less injurious to the Buenos Aires breeders than to those of Entre Rios. The Entre Rios herd was almost annihilated during the revolution, and some of the ranchers of the left bank crossed to the right bank of the Paraná. After I823 the pastoral wealth of Entre Rios was rapidly restored, thanks to raids on Brazilian territory. They were so profitable that the whole population took part in them. In 1827 the inhabitants of Bajada went there in such numbers that the town was half deserted. Every day thousands of cattle were collected on the bank of the Uruguay, and crossed the river. Some of them were even taken beyond the Paraná, to the Santa Fé province. Woodbine Parish confirms this rapid restoration of Entre Rios, of which D'Orbigny was a witness. But this period of prosperity did not last long. The war with Uruguay, under Rosas, again ruined the Entre Rios ranches, and the drought of I846 helped to scatter the remaining herds. Extensive breeding is only lightly rooted in the soil. The chief centres of production change their locality, as the political circumstances change, from one part of the Pampean plain to another.

Primitive breeding affords few examples of periodical migration for the better use of pasturage. In I822, in the course of a journey amongst the Sierras de Tandil and de la Ventana, Colonel Garcia noticed that the Indians kept their cattle round the temporary lagoons of the plain in the winter, and went up to the mountain-

I V. Galvez, Memorias de un viejo (Buenos Aires, 3 vols. in I6mo, $4^{\text {th }}$ ed, , I889). 


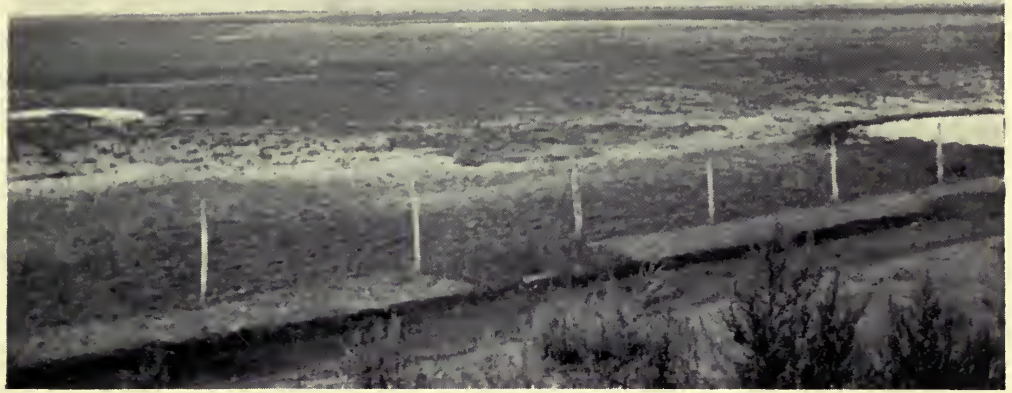

THE PAMPEAN PLAIN. THE RIO BAMBA (IN THE SOUTH OF THE CÓRDOBA PROVINCE, 5OO FEET ABOVE SEA-LEVEL).

Small circular lagoons. The underground water, which comes from the Sierras to the northwest, here reaches the surface. Zone of lucerne farms.

Photograph by the Author.

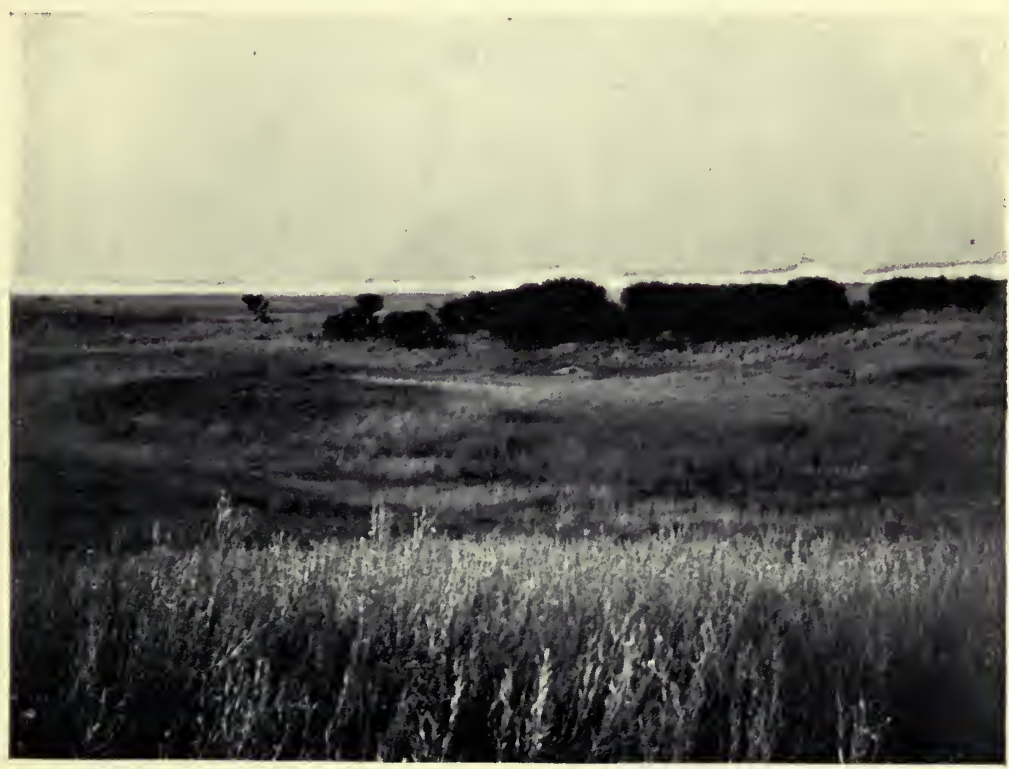

THE PAMPEAN PLAIN. BUENA ESPERANZA (SAN LUIS PROVINCE, I,I66 FEET ELEVATION).

The plain is sown with quick and dead dunes, often shaped in a circle round a lagoon. A dune invaded by vegetation.

Photograph by the Author.

Plate XVI.

To face $p$ 

streams in summer. Transhumation movements of this kind were difficult for the creole ranchers, whose fairly large herds could not be handled easily. The Chascomus breeders, however, at the close of the eighteenth century, drove their cattle to the low banks of the Salado during the dry season. I Garcia also notices the importance of the Salado pastures for the ranches of Salto, Areco, and Lujan.2 The need to remove the herds in the dry season, and to find invernadas within reach of the former ranches, was due to the change brought about in the natural vegetation of the Pampa and the spread of the pasto dulce. The annual herbs which compose the pasto dulce die and disappear after fertilization. Until the autumn rain they leave the ground quite naked, whereas the tough grasses of the pasto duro afforded a thin but permanent pasture.

The first improvements of the pastoral industry of the Pampa are connected with the development of sheep-breeding. Exports of wool began about I840, and made great progress after 1855 ( $I 7,000$ tons in I860, 65,000 tons in I870). From I 850 to about I 890 the economic returns on sheep-breeding were far better than on cattle-breeding. During the whole of this period the multiplication of sheep farms was only restricted by the supply of workers. The first shepherds had been Basques, in the south of the Buenos Aires province, and Irish, in the north. The owner settled them as small farmers in the puestos on the edge of the ranch, the central part of which was devoted to cattle. They could thus, while they guarded their sheep, see that the limits of the estate were respected, and prevent the cattle from roaming.

Wool was for a long time the only product of the

I Diario de un reconocimiento de las guardias y fortines que garnecen la linea de frontera de Buenos Aires (I796), by D. Felix de Azara (Coll. de Angelis, vi.).

2 Nueva plan de fronteras de la Provincia de Buenos Aires por el Colonel Garcia (18r6, Coll. de Angelis, vi.). 


\section{THE PLAIN OF THE PAMPAS}

sheep-rearing industry. From I866 onward it was decided to use the hides and tallow also. As the material of the grease-works was cheap, they spread all over the sheep zone. Many ranches had works of their own. From 1867 to 1877 the saladeros that had been built long before for killing cattle undertook the slaughter of sheep on a large scale. The number of sheep sold to the saladeros rose to $3,000,000$ a year. In 1880 the first cargoes of frozen mutton were sent abroad. The creation of the grease-works had made no difference to the breeding, but the building of the refrigerators brought about a rapid transformation of the flock. The Lincoln breed, heavier and more meaty, displaced the fine-wool Merinos. This substitution of Lincolns for Merinos is now complete throughout the Pampean region.

Until r880 sheep-rearing was concentrated east of the Salado, north and south of Buenos Aires, beginning with a line that passes through Quilmes, San Vicente, Pilar, and Campana, which marks the limit of the suburban zone. In addition it had spread on the right bank of the lower Salado as far as the foot of the Sierra de Tandil, in an area where the first stations date from I823, though the population did not make much progress until after I855. About I880, after the pacification of the Pampa, the sheep-farms began to expand westward. It was then that the wool of the pasto fuerte appeared on the Buenos Aires market. It came from the Azal district in 1870, from Olavarria in 1880 , from Bolivar in 1885 , and from Villegas in I890. The Census of $x 889$ ascribes $5 \mathrm{I}, 000,000$ sheep to the province of Buenos Aires; that of I895 gives much the same figure $(52,000,000)$. Detailed comparison of the two enumerations shows that the expansive movement to the west continued, and was completed during this period. The flocks in the north-west zone of the province (Lincoln, Villegas, Trenque, Lauquen) more than doubled; the flocks of the south-west area 
(Alsina, Puan, Bahía Blanca, Villarino) continued to grow, and increased by a third. Those on the lands of the central Pampa increased threefold. On the other hand, in the departments north and south of the Sierra de Tandil, where colonization is older, sheepbreeding is stationary. The north-east and south-east areas, between the Parana and the Salado, have diminished : one losing a fifth, and the other a half, of its flocks.

From I895 onward the number of flocks of sheep on the Pampean plain decreased rapidly. The number of sheep had sunk from $34,000,000$ in I908 to I8,000,000 in IgI5 for the Buenos Aires province; from 2,800,000 in I908 to $2,300,000$ in I9I4 for the central Pampa. The reduction was general, and found in every district; but it was not equally great everywhere, and did not begin at the same date in every district. Sheep-breeding has almost entirely disappeared from the eastern belt, east of the Salado, which was its cradle. South of Buenos Aires the sheep are giving place to horned cattle, and they had almost disappeared by 1908 . North of Buenos Aires they survived long, but the reduction of the flocks has only been the more rapid since I908. This corresponds with the advance of maize-growing. In six years the Bartolome Mitre and Pergamino departments have lost, respectively, fourfifths and five-sixths of their sheep. In the north-west of the Buenos Aires province the sheep began to be reduced at the time when the lucerne farms were founded, about I900. The decrease has since gone on uninterruptedly. The actual flocks represent onefourth of the flocks of 1895 . In the south-west (wheat belt) there was a rapid shrinkage before I908, but it seems to have almost been arrested since then, thanks to the combining of sheep-rearing with wheat and oats. The actual flocks are about one-half the flocks of 1895. Finally, in the area north of the Sierra de Tandil the sheep retreat before the cattle, as they do 


\section{THE PLAIN OF THE PAMPAS}

further north, but they are not so completely wiped out as in the lucerne belt, and the flocks are still two fifths of the flocks of twenty years ago.

In the province of Entre Rios and south of Corrientes the number of sheep continued to rise until I908, but the increase is only in the northern departments, outside the agricultural belt. The southern departments, which are large growers of wheat and flax, lost one-third of their flocks between I895 and I908.

Cattle-breeding was restricted for a long time by the difficulty of disposing of its products. The hides alone found ready buyers. The making and export of salt beef dates from the eighteenth century, and it was to help this industry that the expeditions to the salt-beds of the Pampa and the journeys of salters to the Patagonian coast were organized. From I792 to 1796 no less than 39,000 quintals of jerked beef were sent from the Rio de la Plata to Havana. But the market for salt meat (tasajo) was always limited. It consisted only of the Antilles and Brazil, and the saladeros never fully exploited the meat-producing capacity of the Argentine herds. The crisis of the saladeros occurred before the time when the refrigerators began to compete with them. By I889 there were only three left in the province of Buenos Aires.

Although the price of cattle was not very remunerative, and provided no incentive to improve the breeding ; although the saladero was not at all exorbitant, merely asking for animals in good condition, the improvement of the herd by introducing selected pedigree-breeders had begun about the middle of the nineteenth century. The Basque dairies established in the district near Buenos Aires sold pedigree-calves to the ranches, and these were used for breeding purposes. ${ }^{x}$ About 1880 the advance of sheep-breeding pressed the cattle-ranches

I This is, in a special form, the first instance of specialization, in the cantons of the Pampean region, in the breeding industry, properly so called (producing breeders). 
back and disputed the space with them more and more, within the ancient Indian frontier. The smallness of the market for cattle and their slight mercantile value were very favourable circumstances for the occupation of the new lands, thrown open at this date by the submission of the Indians. The herds which found no buyers were sent to the campos de afuera. The ranches developed very rapidly. Daireaux has very accurately described this period of pastoral colonization, and the starting of convoys that were intended to give a population to the west of the Pampa. Cattle were there several years before sheep. As a matter of fact, breeders do not regard cattle as having a value of their own. They are merely auxiliaries that must improve the pasture and prepare the ground for sheep. The cattle themselves are preceded by troops of half-wild horses which first take possession of the virgin field and begin the transformation of it.

The number of cattle increases rapidly. In I875 it was estimated that there were $5,000,000$ head of cattle in the province of Buenos Aires. In I 889 there were $8,500,000$. Since that date the variations have been comparatively slight. The Census of 1895 gives $7,700,000$; that of 1908 gives $10,300,000$; that of I9I4 gives $9,000,000$; and that of I9I5 gives II,300,000. ${ }^{\mathrm{I}}$ But the value of the cattle has gone up rapidly. The exports of live meat, which lasted from I889 to I900, were the beginning of the rise. It was strengthened when the refrigerators ceased to confine themselves to killing sheep and began to buy cattle. The exports of chilled or frozen beef increased after 1898. The value of them rose to $10,000,000$ gold piastres in I904, double that in I909, and more than quadruple in IgI4.

I The variations in number are less considerable for the Pampean region than for the whole of Argentina. It is better supplied with capital than the other breeding districts, and can rapidly replace the losses caused by excessive export by buying cattle in the adjoining provinces. 


\section{THE PLAIN OF THE PAMPAS}

The difference between the price paid by the refrigerators for pedigree-cattle and the price of animals of creole blood, which the local market takes, hurries up the transformation of the herd. In order to watch reproduction and nurse the pasture, the ranches put up wire-fences. But the breeding methods are especially modified by the introduction of lucerne. It spread in the south of Cordoba and west of the Buenos Aires province from I895 onward, and from I905 onward in part of the San Luis province. There were already small lucerne farms in the Buenos Aires province. A description that was written at the end of the eighteenth century speaks of lucerne farms round the town which were reserved for feeding draught cattle. ${ }^{\text {I }}$ But the area from which the cultivation of lucerne started at the close of the nineteenth century is the district of the Córdoba province that is crossed by the line from Rosario to Córdoba, completed about I870 to Bellville and Villa Marina. The lucerne farms there were not created by the breeders, and the lucerne was at first intended for export to Rosario and Buenos Aires in the form of dry fodder. The trade in dry fodder has remained good there. The I908 Census gives I28 square kilometres of lucerne for cutting in the Tercero Abajo department (Villa Maria) and 267 square kilometres in the Union department (Bellville). ${ }^{2}$

The lucerne spread southward and south-westward from this point; and the improvement of the herds kept pace with it. I have shown elsewhere how this improvement was checked north of a line along the course of the Paraná, the northern frontier of the

- Fernando Barrero, Descripcion de las provincias del Rio de la Plata (published by the Argentine Ministry of Foreign Affairs, Buenos Aires, I9II).

- Amongst the specialized industries connected with the development of the lucerne farm - we must mention the growing of lucerne for seed, which has settied in the dry zones, where the lucerne is not so much invaded by other species ; for instance, the district of Madanos, west of Bahía Blanca. 


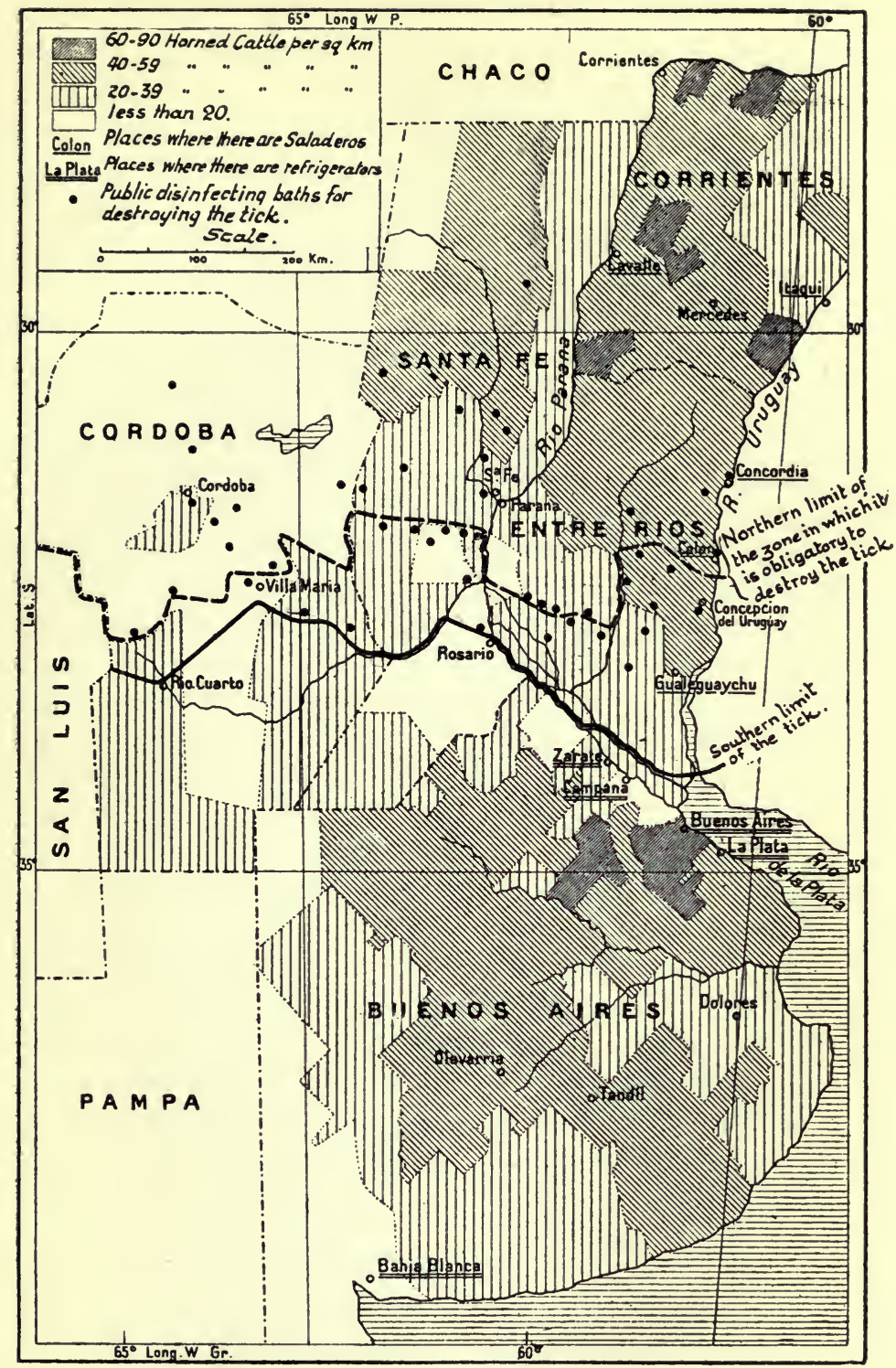

MAP III. - THE CATTLE-BREEDING AREAS.

The density of the herd is slight in the maize belt. It is considerable in the centre and east of the Pampean region, which supply the refrigerators with pedigree stock of good weight. The density is considerable also in the north of Mesopotamia, but the cattle there are less valuable and are taken by the saladeros of the Uruguay. The presence of the tick, which inoculates cattle with Texas fever, is the chief obstacle to the improvement of the herd in the north of Argentina. 

Constitución and General Lopez departments, in the province of Santa Fé and on the Rio Cuarto, and in the Córdoba province, by the presence of the garrapate, which inoculates the cattle with a dreaded disease, Texas fever. The creole cattle are immunized against the garrapate, but pedigree cattle quickly succumb to it. In order to protect the southern zone, where the garrapate does not reproduce, the Argentine Government imposes severe restrictions on the transport of cattle from north to south; the cattle have to have disinfectant baths at the frontier-stations. This cuts pastoral Argentina in two. While the Durham cattle of the south are intended for the refrigerators, the creole cattle of the north still supply the saladeros, which have disappeared from Buenos Aires, but survive on the Uruguay. Yet the advantages of crossing with European breeds are such that the northern breeders, in spite of the risk and the expense, have not given up all hope of accomplishing it. The transformation of the herd, however, is bound to be very slow. Pedigree breeders are brought from the south and kept in the stable. Their progeny, born on the spot, resist Texas fever better and can be put out to pasture. There has been more progress in the contaminated zone on the right bank of the Paraná than in Entre Rios and Corrientes. Pedigree animals have been introduced at Santa Fé, not only in the region of the colonies, but further north, in the extreme northern corner of the Pampa (San Cristobal department), colonized by ranchers from the north of Buenos Aires and the south of Santa Fé, who were ousted by the progress of maize. They have brought with them to the new lands the cultivation of lucerne and the methods they followed on their former property. At Corrientes, on the other hand, breeding is an historic industry. The staff of the ranches is indigenous. The pastoral traditions are unchanged.

When we study the variations in the numbers of cattle in different parts of the Pampa, by comparing 


\section{THE PLAIN OF THE PAMPAS}

the results of recent Censuses we find that the number has risen rapidly since $\mathrm{I} 895$ in the whole of the eastern area, north of the Sierra de Tandil. The increase is particularly conspicuous north of the Rio Salado, in the dairy district. (Mean density in I9I5, 40 to 60 horned cattle per square kilometre.) In the southwest region (wheat belt) the density has always been low (I2 per square kilometre), and it shows no tendency to increase. In the north and western region of Buenos Aires (lucerne belt) there has been a rapid increase, especially between I895 and I908 (creation of the lucerne farms), and it has not been interrupted since (density 50 to the square kilometre). There is the same increase in the whole area of the lucerne farms in the Córdoba, Santa Fé, and San Luis provinces, where the herds doubled beween 1895 and I908. Only two regions have suffered a reduction: the agricultural area of the centre (Chacabuco, Chivilcoy), where there has been a decrease since I895, and the maize district (north of Buenos Aires), where cattle-rearing did not diminish until after I908.

Agriculture had begun to develop by the end of the eighteenth century in the district round Buenos Aires. D'Azara admits the enormous preponderance of breeding, but mentions that the right bank of the Parana exported flour to the left bank, which was exclusively pastoral. Barrero also observes that between the belt of orchards and lucerne fields, about a league in width, which surrounded Buenos Aires, and the area of the ranches, which did not begin for six or eight leagues, there was an agricultural belt, the district of the chacras de pan llevar. The main crop was wheat, and the tillage was chiefly done in the rich soils at the bottom of the valleys, which are called cañadas in the local dialect (cañada de Moron, cañada du Rio Lujan, etc.).

It was, however, not at Buenos Aires, but in the Santa Fé province, that modern agricultural coloniza- 
tion began in the nineteenth century. It goes back to the foundation (in I854) of the colony of Esperanza, west of Santa Fé, from which it was separated by the strip of forest which follows the course of the Salado. European immigrants-Swiss, French, and Piedmontese -had settled there. The early years of colonization at Santa Fé were difficult, and the colonies did not begin to develop rapidly until after I870. About that date we can distinguish three nuclei of agricultural colonization at Santa Fé. The first group of colonies was settled in the north, on the bank of the Paraná. In the centre the Esperanza group advanced steadily westward. A third group of colonies lay along the Central Argentine railway from Rosario to Córdoba.

The Esperanza colonists had at first grown maize, but the prosperity of the colonies was mainly due to wheat. Zeballos, who visited the colonies in I882, describes them as a vast lake of wheat. Wheat predominates, not only in the department of Las Colonias, west of Santa Fé, where it survives in full strength, but further north, at Garay, whence it has since been displaced by flax and earth-nuts, and in the south, round Rosario, in the belt which is now given up to maize. It is for the wheat that the mills of Carcaraña and the granaries of Rosario have been built. The land sown with wheat at Santa Fé rose in I882 to I02,000 hectares out of a total of I27,000 hectares of cultivated land. $x$ By 1889 the area of wheat was quadrupled. It spread like a drop of oil, reaching Rafäela and Castellanos on the west. In I895 the advance was still more rapid. Wheat-growing has crossed the Córdoba frontier, and spread round San Francisco and east of Mar Chiquita (departments of San Justo and Marcos Juarez). The agricultural regions in the centre of the Santa Fé province and

- The population of the Santa Fé colonies in 1882 was 52,000 , of whom 12,000 were in the colonies of the San Javier, north of the town of Santa Fé. 


\section{THE PLAIN OF THE PAMPAS}

those of the Central Argentine have met, and the wheat has invaded the whole of the San Martin department. It extends even south of the old colonies of the Central Argentine toward the south-west of Santa Fé, in the General Lopez department.

The I908 Census shows a very different state of things. The density of the wheat-cultivation has continued to grow appreciably in the whole of the northern region, and also in the south-west of the province, at some distance from the Paraná (General Lopez department). On the other hand, it has been reduced in the adjoining district of Rosario (departments of Iriondo, Belgrana, Caseros, and Constitución), where maize-growing has developed. Maize has won part of the wheat belt.

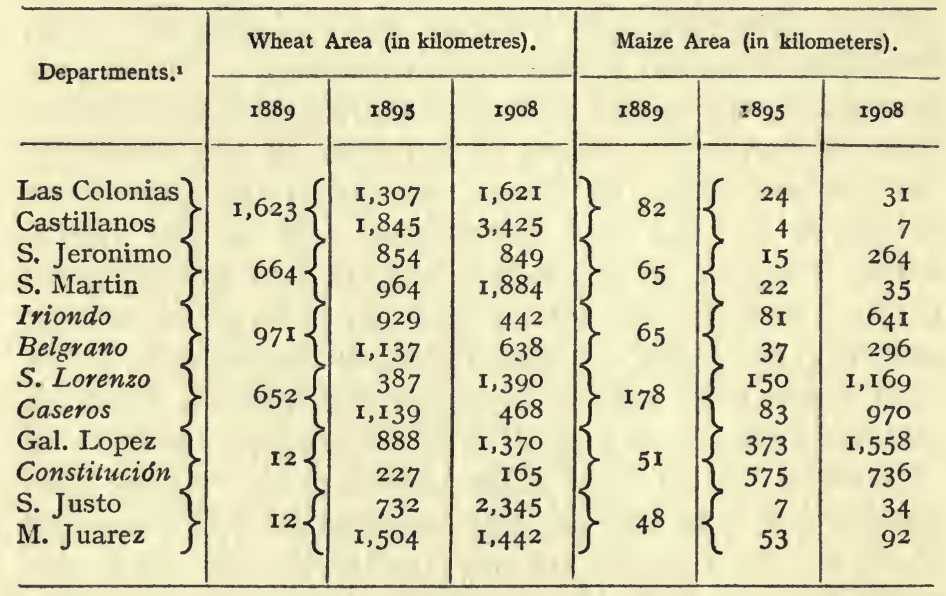

Restricted in the south by the extension of the maize belt, the region of the colonies has now a very distinctive character amongst the agricultural areas of the Pampa.

× The names of departments which belong in their entirety to the maize region are given in italics. The department of San Jeronimo straddles the maize region and the region of the colonies. The General Lopez territory also extends, in the south-west, far beyond the limit of the maize belt. 
This originality is not so much in virtue of its crops (hard wheat and flax) as on account of the age of colonization and the division of property. Most of the colonists are owners, and estates of 50 to 200 hectares are the rule. The houses are comfortable ; they are surrounded by orchards and kitchen-gardens. Moreover, the rural economy has been complicated, and it has assumed a familiar aspect for the European observer, owing to the introduction of cattle-rearing on a small scale by the farmers. The number of horned cattle doubled between I908 and I9I4 in the Castellanos department, and increased by a third in Las Colonias. The area of lucerne has extended in proportion. The farms have been multiplied on the low lands (cañadas), unsuitable for wheat, which the older colonists had disdained; but they are now regarded as the best bits of land. The recent rise in the value of land in the region of the colonies is connected, not with an increase of agricultural production, but a development of breeding. A few co-operative diary societies have been established. In general, however, breeding is solely for the meatmarket. The cattle-trade goes on very different lines from those of the large estates and ranches. It has remained in the hands of small dealers (Jews of Moisesville).

Agricultural colonization in the Buenos Aires province was at first entirely independent of the Santa Fé colonization. The crops of the adjoining region of Buenos Aires never disappeared altogether. In the period to which Daireaux's description of the economic life of the Pampa refers (I880-89), the farmers disputed with the breeders a belt some ten leagues broad round the capital. But sheep-breeding left no place for agriculture in the next belt, which enclosed the first on every side, and extended almost as far as the Salado. Agricultural colonization had found free land only beyond the sheep-farm area, I70 miles west of Buenos Aires, round Chivilcoy, Chacabuco, and 


\section{THE PLAIN OF THE PAMPAS}

Bragado. As early as 1872 the Chivilcoy district produced 130,000 hectolitres of wheat; or nearly half the total production of the Buenos Aires province. In I889 it formed a comparatively dense agricultural patch, the cultivated area being devoted half to wheat and half to maize.

\begin{tabular}{|c|c|c|c|}
\hline Chivilcoy & - & $\begin{array}{l}\text { Wheat. } \\
307 \mathrm{kms} \text {. }\end{array}$ & $\begin{array}{l}\text { Maize. } \\
399 \mathrm{kms} \text {. }\end{array}$ \\
\hline Chacabuco & .. & I $55 \quad$, & I64", \\
\hline Bragado & .. & $\ldots \quad \mathrm{I} 47$, & $26 I$ \\
\hline
\end{tabular}

At that date the whole west and south of the Buenos Aires province was exclusively pastoral. There were only two isolated nuclei of agricultural colonization. The first was round Olavarria, on the old Indian frontier, where Russo-German colonies had been established in I878. The second was in the Suarez department, at the extreme north of the Sierra de la Ventana, where a group of French colonists settled five years later, at Piguie. I The opening of the line from Buenos Aires to Bahía Blanca ought, one would think, to have prepared the way for agricultural colonization in this section. However, the I895 Census shows a check to these first attempts at tillage in the south. It fell by one half at Suarez, and by three-fourths at Olavarria. The Pigüe colonists have succeeded in keeping to their lands, but those of Olavarria have abandoned them, and most of them have emigrated to the Entre Rios province.

On the other hand, colonization has kept the land won in the district of the middle Salado, and it extends in a sporadic way toward the south-west and west. (Nueve de Julio, 252 square kilometres of wheat and 400 of maize: Veinte Cinco de Mayo, 84 square kilometres of wheat and 2 I8 of maize: Junin, I97 square kilometres of wheat and 204 of maize in I895). It has been maintained ever since, with slow progress, but without being ousted by breeding. This is one

I Wheat-area in 1889 in the Olavarria department, 319 square kilometres; in the Suarez department, II 8 square kilometres. 


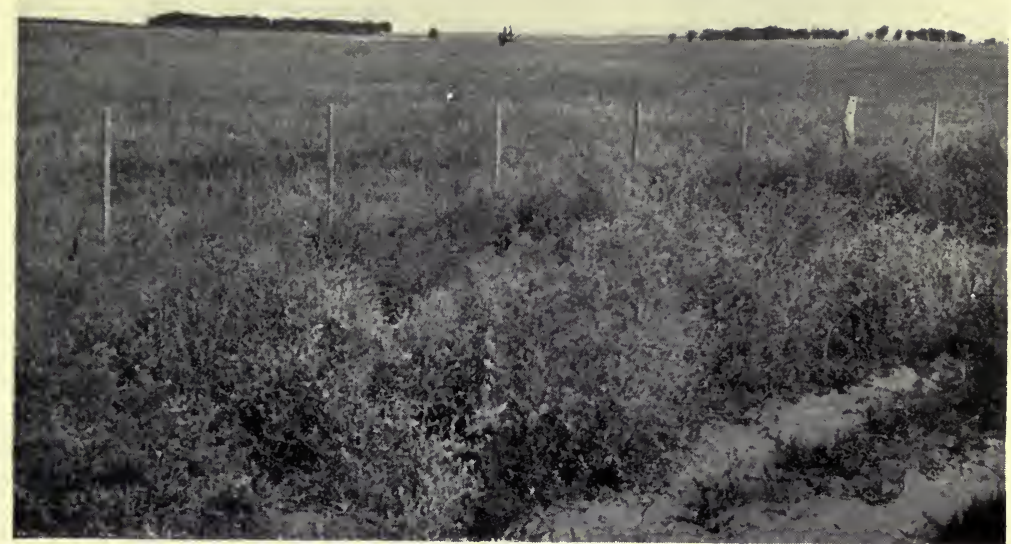

THE PAMPEAN PLAIN. BUENA ESPERANZA (SAN LUIS PROVINCE). The first chañares.

Photograph by the Author.

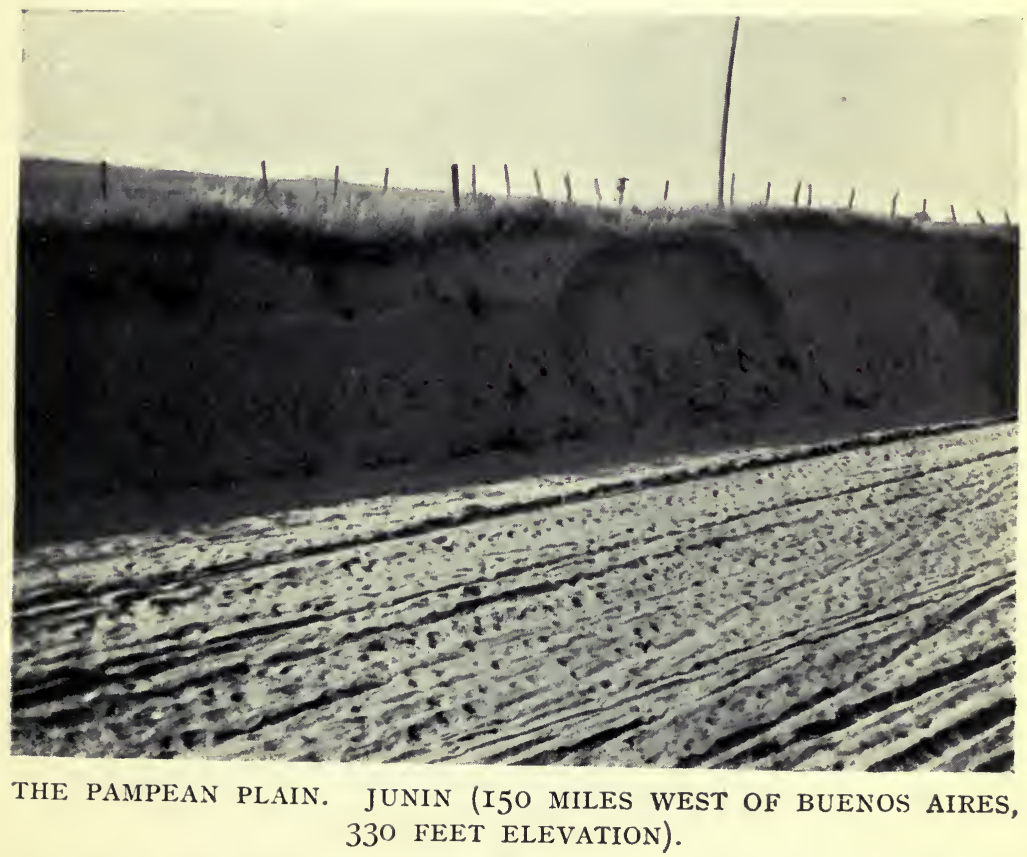

The clays. A line of dead dunes crosses the Junin district, following the course of the Salado. They are indicated by light, sandy soil, very different from the clays of the north of Buenos Aires province. Pt,Ate XVII. 

of the regions of the Pampa where the most different types of rural exploitation are mingled together. Agricultural colonization has been carried on both by small proprietors and farmers or tenants. Wheat and maize seem to be permanently associated, and the climate is equally good for both; the maize crop being the better if the summer is wet, and the wheat crop when the summer is dry. The two cereals follow each other on the same land, in rotation, the wheat being helped by the constant weeding and clearing which the maize requires. The colonists use oxen in the work, and fatten them afterwards. ${ }^{x}$

Agricultural colonization in the lucerne region dates from 1895 to I905:

\begin{tabular}{|c|c|c|c|c|c|c|c|}
\hline & & & & \multicolumn{2}{|c|}{$\begin{array}{l}\text { Wheat Area } \\
\text { (in kilometres). }\end{array}$} & \multicolumn{2}{|c|}{$\begin{array}{c}\text { Flax Area } \\
\text { (in kulometres). }\end{array}$} \\
\hline & & & & 1895 & 1908 & 1895 & 1908 \\
\hline \multicolumn{8}{|c|}{ Buenos Aires : } \\
\hline Lincoln & .. & .. & .. & 152 & 819 & - & 100 \\
\hline Pehuajo & .. & .. & .. & 106 & 727 & - & - \\
\hline Guamini & .. & .. & .. & 20 & 528 & - & - \\
\hline \multicolumn{3}{|c|}{ Trenque Lauquen } & .. & 100 & $\mathbf{1 , 4 3 9}$ & - & 59 \\
\hline Villegas & .. & .. & .. & 4 & 812 & $\mathbf{I}$ & 84 \\
\hline Pinto & .. & .. & .. & - & 469 & - & 60 \\
\hline \multicolumn{8}{|l|}{ Córdoba : } \\
\hline Gal. Roca & .. & .. & .. & - & 1,009 & - & 89 \\
\hline Rio Quar & & .. & .. & 5 & I, 156 & - & 172 \\
\hline Juarez Ce & & .. & .. & I 44 & 1,679 & - & 183 \\
\hline Union & .. & .. & .. & 373 & $2,54^{8}$ & 12 & 316 \\
\hline
\end{tabular}

I have shown how this was bound up with the development of the lucerne farms themselves. The extreme

1 Draught animals in 1908: at Chivilcoy, 17,000 cattle and 10,000 horses; at Junin, 15,000 cattle and 6,000 horses ; at Nueve de Julio, I 5,000 cattle and 6,000 horses. In the region of the Santa Fé colonies : at Castellanos, I 7,000 cattle and 54,000 horses; at Las Colonias, 6,000 cattle and 35,000 horses. In the wheat belt (South of Buenos Aires) : at Puan, (no cattle) 29,000 horses. At the sierras (no cattle), 14,000 horses. 
west of the lucerne belt (Pedernera department and San Luis) is the only place where the cultivated area was reduced. The contracts by which the ranchers entrust their lands to the colonists, on condition of returning them sown with lucerne, were gradually modified as the stream of colonization developed. The land was at first left to the colonist rent free, the rancher being paid by the creation of the lucerne fields. But in proportion to the increasing volume of the stream of immigrants, and the keener competition of the colonists, the rancher asked better terms. There are similar contracts in regard to the restoration of lucerne fields which have been worn out by pasturage, so that the land has to be ploughed up periodically. The men who clear the land in the lucerne belt have mostly been recruited in the district of the old colonies of Santa Fé, where the new generation had begun to feel the pinch. The crops which they raise during the four or five years of their lease are chosen without any idea of sparing lands which they are not to keep. Wheat succeeds wheat, and the first and last crop is often flax. The proportion of flax is lower only in the southern part of the lucerne belt. In the Buenos Aires province the colonist grows lucerne on his own account, either to sell as dry fodder or for breeding or fattening.

Colonization does not in these parts correspond with the division of property. Not only does the farmer not become the owner of the soil, but he does not live on it permanently; he is a veritable nomad. His house has a temporary look that strikes one at the first glance. The area cultivated is almost stable, if the region is considered as a whole. But cultivation passes periodically from one section to another, and its removals cause sudden alterations or crises in the railway traffic and the development of the urban centres.

The lucerne belt has been peopled by Santafecinos, and it has in turn sent colonists to the western agricul- 


\section{INCREASE OF MAIZE CROPS 197}

tural belt at the foot of the Sierras de San Luis and de Córdoba. They have less suitable climatological conditions, but they have the advantage of greater stability, as the breeders do not dispute the land with them.

While agricultural colonization has been an aid to pastoral colonization in the north-west of Buenos Aires, it tends to displace breeding, or restrict its sphere, in the north-east and the south. Maize-growing started on the banks of the Paraná, where it was already paramount in I889, between Campana (north of Buenos Aires) and San Nicolas. In I895 it advanced up the Paraná as far as the Santa Fé province (Constitución) and spread over the interior for some sixty miles in the Salto department. In the next few years it made rapid progress toward the west and north-west, covering the departments of Pergamino, Rojas, and Colon, and part of General Lopez, San Lorenzo, and Constitución in the province of Santa Fé.

\begin{tabular}{|c|c|c|c|c|c|c|}
\hline \multirow[t]{2}{*}{ f } & \multicolumn{3}{|c|}{ Maize Area. } & \multicolumn{3}{|c|}{ Flax Area, } \\
\hline & I889 & 1895 & 1908 & 1889 & 1895 & 1908 \\
\hline Campana . & 67 & 45 & 22 & I 5 & $3 I$ & 17 \\
\hline Baradero & 339 & 260 & 291 & 26 & 78 & I 73 \\
\hline S. Pedro & 398 & 353 & 420 & 5 & 73 & 235 \\
\hline Arrecifes & 124 & 126 & I 55 & I 5 & 50 & 265 \\
\hline Salto... & I6 & 326 & 236 & 13 & 3 & 75 \\
\hline Gal. Lopez & & $\int 373$ & $1,53^{8}$ & - & 70 & 752 \\
\hline Constitución & $5 \mathrm{I}$ & $\left\{\begin{array}{l}575 \\
575\end{array}\right.$ & 736 & - & 270 & 404 \\
\hline Pergamino & I 68 & 160 & $34^{\circ}$ & 50 & 30 & 275 \\
\hline Rojas & 86 & $8 I$ & 247 & 4 & 23 & 275 \\
\hline Colon... & - & 44 & 126 & - & 14 & 78 \\
\hline S. Lorenzo & 178 & I 50 & 1,169 & I I & 36 & 450 \\
\hline Caseros & - & 83 & 990 & - & 13 & 319 \\
\hline
\end{tabular}

Export of Argentine maize on a large scale began in I895. Flax-growing was not added to maize until I900.

The heavy land requires a good deal of harrowing, 
and the weeding and harvesting of the maize give employment to a comparatively large staff. The estates are of moderate size, often only 50 hectares. Ownership was not divided at the period of colonization, the land, thanks to the breeders, having already acquired so high a value that the colonists could not buy it. On the lands which have been farmed out there has developed a rural, and often far from docile, proletariat. It is in the maize region that the worst agricultural strikes have taken place. The struggles of the owners and the colonists are the more prolonged because the sowing of the maize can be put back to the end of the spring without much harm being done. The adjoining zone of the Paraná produced some of the maiseros who have scattered over the north-west. But the modern colonies include, in addition, a large proportion of immigrants who have recently landed from Italy and Spain. The maize growers do not mix with the wheat-growers. Each group has its own area.

The increase of wheat-growing in the south dates only from 1898 :

\begin{tabular}{|c|c|c|c|c|c|}
\hline & & \multirow[b]{2}{*}{ 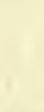 } & \multirow[b]{3}{*}{.. } & \multicolumn{2}{|c|}{ Wheat Area (in kilometres). } \\
\hline & & & & 1895 & \multirow{2}{*}{$\begin{array}{c}\mathbf{I 9 0 8} \\
\mathbf{I , 2 9 6}\end{array}$} \\
\hline Alsina ... & .. & .. & & 45 & \\
\hline Puan .. & .. & .. & .. & 52 & 1,321 \\
\hline Suarez .. & .. & .. & .. & 104 & 978 \\
\hline La Madrid & .. & .. & .. & 75 & 249 \\
\hline Pringles & . & .. & .. & 13 & 724 \\
\hline Darrego & .. & . & .. & - & 885 \\
\hline \multicolumn{2}{|c|}{ Terr. de la Pampa } & .. & .. & - & $\mathbf{I}, 73 \mathbf{I}$ \\
\hline
\end{tabular}

Wheat first spread along the line from Buenos Aires to Bahía Blanca, west of the Sierra de la Ventana, then in the coastal district, east of Bahía Blanca. These two wheat-areas became connected after I904, when the opening of the direct line from Olavarria to Buenos 


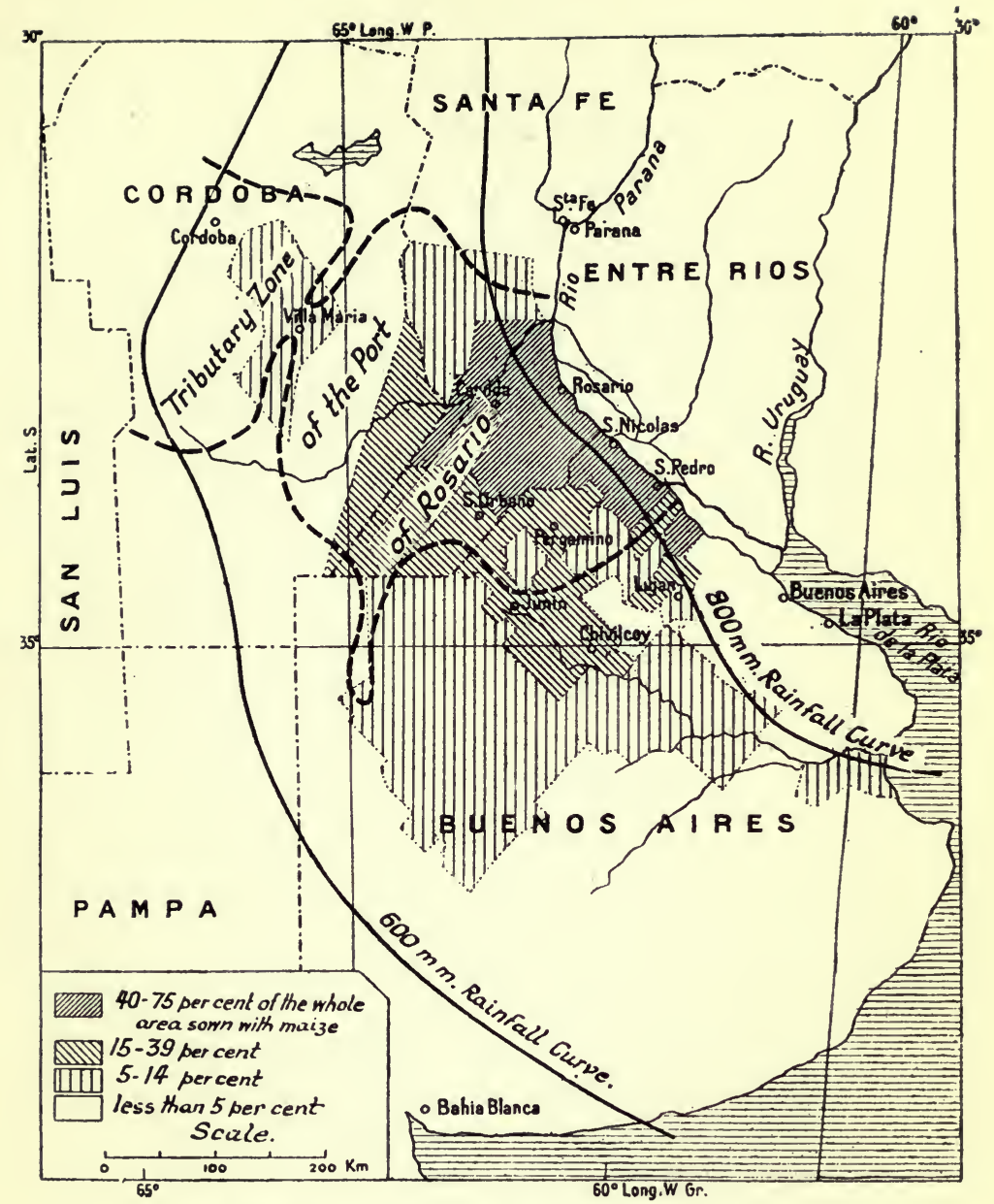

MAP IV.-DENSITY OF THE MAIZE CROP.

As it needs more heat and moisture than wheat, the maize does not go so far to the west and south. It is concentrated for export at the ports of the Rio de la Plata and the Paraná, especially at Rosario. The Argentine "corn belt," the chief maize area, extends back of Rosario and San Nicolas to beyond Casilda and Pergamino. 

Aires facilitated the development of the intermediate region (Pringles-Laprida). From Bahía Blanca it spread to the west and north-west along the Toay line, and southward as far as Colorado on the coast. In the whole area of the Central Pampa it is still possible to distinguish two strata of immigrants, of different dates, one superimposed upon the other: the sheepbreeders and the farmers. Round Toay the contrast between the two elements of the population is even more striking, because the first pastoral colonization, which dates from I890, was to a great extent the work of creole puntanos (from the San Luis province). The actual agricultural colonies, on the other hand, include recent European immigrants and colonists from other parts of the provinces of Buenos Aires and Entre Rios.

The yield of the wheat grows less and less as one goes westward. The harvest may be injured either by late frost or drought, or, especially, by hot winds which scorch the plants and blight the half-realized hopes of the farmers in the weeks just before the harvest. But the relative poorness of the return is compensated by the extent of the farms and the cheapness of labour. The harvest is often done with machines that peel and pack the wheat, and the workers are not compelled, as they are at Santa Fé, to wait for the threshing machine. The aridity does not permit flax-growing, but oats can be grown, especially between the Sierra de la Ventana and the Sierra de Tandil; and it is good to sow oats when the land has been impoverished by consecutive crops of wheat. Exports of oats through Bahía Blanca began in 1906.

The displacement of breeding by farming is less thorough than in the maize belt. Oats, sown about the beginning of autumn, serve for fodder. The animals are kept in the fields during the winter, and the oats are cut and put into the mill, without being threshed, as a reserve fodder. Moreover, the wheat 


\section{THE PLAIN OF THE PAMPAS}

farmers have themselves taken to rearing sheep, and the sheep feed in the stubble and fallow.

From this short account of the history of colonization we draw certain important conclusions. At the time when agricultural colonization began, it was admitted that farming was the best way to exploit the soil, and that the Pampa would sooner or later pass from the pastoral to the agricultural cycle; or, to use the local phraseology, that the "colony" would replace the ranch everywhere. This idea was wrong. The only area in which the facts seem to give it any support is the corn belt. The general rule is, on the contrary, that in its progress colonization develops a mixed type of exploitation, combining farming and breeding; either one alternates with the other in a sort of periodic rotation, as in the lucerne area, or both proceed together, the farmers including breeding amongst their occupations, as in the district of the Santa Fé colonies or in the wheat area in the south of the Buenos Aires province.

It seems, moreover, that the development of colonization depends not only upon physical conditions, but upon factors of a purely economic or social character, which the geographer must not overlook. It will be enough here to indicate the chief of these.

We have seen the part that has been played in the exploitation of the soil by groups of colonists who swarm from one area to another. Whether we think of the ranchers of the eastern part of Buenos Aires transplanting themselves to Córdoba or north of Santa Fé, the sheep-breeders moving westward, or the Santa Fé colonists settling in the lucerne area, they all take with them their own habits and methods of work, and they take time to adjust them to a new environment.

The colonist, whether breeder or farmer, is not left to himself. Colonization is sustained and directed by speculation in land, and is influenced by it. Speculation discounts the work of the colonist, and attaches 


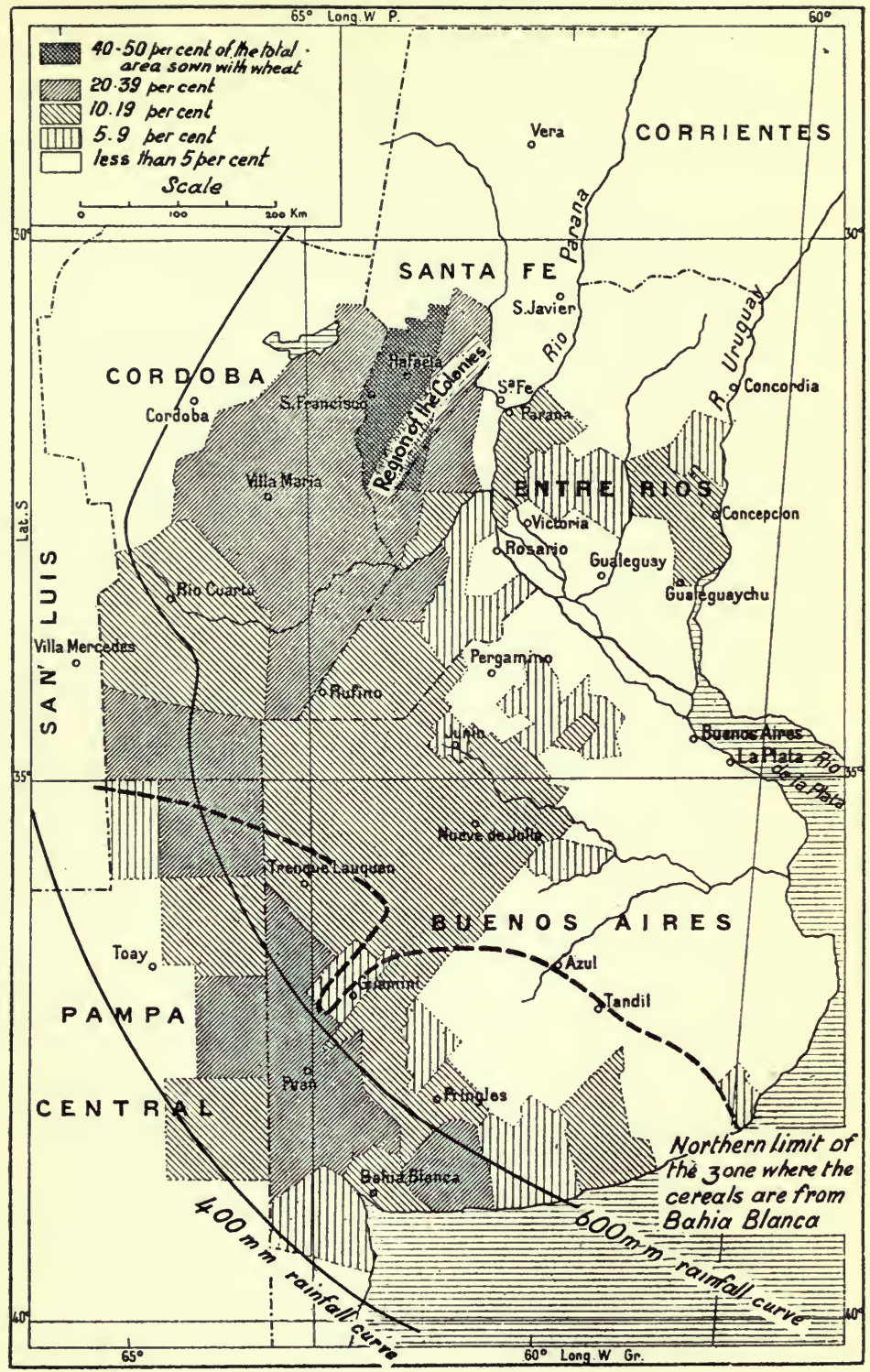

MAP V.-DENSITY OF THE WHEAT CROP.

The wheat belt stretches in a broad section of a circle from Bahia Blanca to Santa Fé, which is now reached by maritime vessels. The cultivation of wheat crosses the line of 600 millimetres of rainfall, and even the 400-millimetre line, in proportion as one passes from the area of summer rain to that of spring and autumn rain.

To face p. 200 . 

to the land a value which is not based upon the revenue it has produced, but upon that which the speculator calculates that it may produce in the future. If the speculator is audacious, he does not let himself be discouraged by initial bad experiences; it takes repeated checks to exhaust his optimism. The colonist, even if his farming accounts do not show a profit, may nevertheless gain something if the value of his land goes up. The increase of his capital conceals from him the smallness of his returns, especially as he can easily get advances on the value of his property from the banks, and this enables him to draw upon his wealth every year.

Speculation is concerned with new lands on the fringe of the area already colonized, where the soil is, as a general rule, already in the hands of the exploiters themselves. The speculators, having paid a high price for these lands, try to organize the development of them. It is partly owing to their influence that colonization continuously enlarges its domain, instead of concentrating its labour in the older districts where it might sometimes be more productive. In fine, speculation in land has a profound influence on the conditions of colonization, making it more difficult for the colonist to buy the land he is developing. The owner who grants him the use of the land means to keep for himself any increment of its value. He rents, but he will not sell.

Thus the history of colonization cannot be separated from the traffic in land. The special features of this traffic in the Pampean region-its concentration at Buenos Aires; the creation of a land-market resembling a stock market ; the practice of selling on the instalment plan, which enables small capitalists to enter the market; the repeated transfers of pieces of land which the buyers have never seen and which they know only from plansare one of the most original aspects of modern Argentina. They are partly due to a fact of a geographical nature- 


\section{THE PLAIN OF THE PAMPAS}

the uniformity of the Pampean plain, on which every piece of land is worth about as much as the adjoining piece.

Colonization is easy and rapid in proportion as it requires less capital and labour. The expansion of breeding in the west between 1880 and 1890 was facilitated by the low market price of cattle at that time. Breeding has the advantage over farming of not needing so large a staff, but it requires a larger capital. Of the crops, assuming that the conditions of soil and climate are equally favourable, wheat is better than maize for colonization, because the preparing of the soil and the harvest can be done more speedily, and the same number of hands can plant a larger area with wheat than with maize.

The action of the Argentine Government and the provincial authorities has been restrained, apart from the earliest period of the establishment of the Santa Fé colonies, both as regards the securing of immigrants, the distribution of lands, and the administration of the colonies. ${ }^{x}$ Colonization has been, on the whole, a private affair. The work of organizing colonization has at times been undertaken by the proprietors themselves; they leased pieces of land and got a good price for them, at the same time increasing the surplus value of the plots they kept for themselves by promoting the increase of population. Sometimes it was undertaken by Colonization Companies, which bought land to divide and sell. More frequently it was undertaken by merchants who advanced credit to the colonists they settled, on condition that the colonists bought

- The Agricultural Centres Law, passed in 1887 by the province of Buenos Aires to encourage colonization, has not had good results. By the terms of this law, owners who professed themselves willing to devote their lands to colonization received an advance on the value of the lands in the form of mortgages, the interest and repayment of the mortgage being charged to the colonists. Many owners took advantage of the law, but, after a pretence of colonization, kept the ownership of their lands. 


\section{THE MARKETS OF THE PAMPA 203}

what they needed of the merchants, and entrusted them with the sale of their crops. The migration of the Santa Fé colonists was partly due to, and sustained by, a corresponding migration of merchants who had acquired wealth in the older colonies, and who thus got a larger body of customers. The merchant who organizes colonization often acts as the intermediary between the owner and the colonist, guaranteeing the owner a fixed rent for his land and receiving so much per cent. of his harvest from the farmer. This system is very widespread in the corn belt, but it is found all over the plain of the Pampas. It tends to disappear when the colony is older and deeper-rooted, as the colonist gradually earns his independence; he buys his lease, his equipment, and his furniture, and controls the sale of his own crops. In the districts where he has not become owner, the leases are generally variations of two types: farming leases, where the colonist has capital enough for working, and renting leases, where the capital is provided by the owner or the middleman.

Lastly, colonization can make no progress unless it finds markets on which it can put its produce. Up to the present western Europe has been the chief market for the wool, leather, meat, and cereals of the Pampean region; tropical America absorbs part of the output of the saladeros, flour, and dry fodder; and North America has recently begun to compete with Europe for wool, leather, and frozen meat. The facility with which the products of the Pampa have found their way into the world's markets, as is seen in the comparative stability of the returns, explains the continuous advance of colonization and the short duration of the crises which have disturbed it.

The home market, however, has had an importance in connection with colonization that must not be overlooked. When wheat-growing spread at Santa Fé the crop was at first devoted to supplying Buenos 


\section{THE PLAIN OF THE PAMPAS}

Aires, and as late as 1883 Zeballos thought that the essential result of agricultural colonization was the fact that Chilean flour was beaten off the Argentine market. Even to-day the districts on the outskirts of the cereal area depend upon the home market. The Villa Mercedes mill supplies Mendoza. Córdoba and Santa Fé send their flour to Tucumán. The price of cereals still shows slight fluctuations in these parts as compared with prices in Buenos Aires.

Pastoral colonization, again, has not been entirely

Table of Exports of the Chief Products of the Pampean region (in thousands of tons):

\begin{tabular}{|c|c|c|c|c|c|c|c|}
\hline & & & 1901 & 1905 & I9ro & I9I3 & I914 \\
\hline Wheat.. & . & .. & 904 & 2,868 & I, 883 & $2,8 \mathrm{r} 2$ & 980 \\
\hline Maize .. & - & .. & I, I I 2 & 2,222 & 2,660 & 4,806 & 3,542 \\
\hline Flax $\ldots$ & -. & .. & 338 & 654 & 604 & I, oI 6 & $84 r$ \\
\hline Flour .. & .. & .. & 71 & I 44 & I 5 & 124 & 67 \\
\hline Wool .. & .. & $\therefore$ & 228 & I9I & 150 & 120 & I I 7 \\
\hline Salted hides & .. & .. & 28 & 40 & $6 x$ & 65 & 63 \\
\hline Dried hides & . & .. & 26 & 24 & 29 & $2 I$ & 14 \\
\hline Chilled beef & .. & .. & 44 & 152 & 253 & 306 & 368 \\
\hline Chilled mutton & & - & 63 & 78 & 75 & 45 & $5^{8}$ \\
\hline
\end{tabular}

The heading "cereals" appears in the statistics of Argentine exports in 1882 . In 1900 the value of the agricultural produce exported is equal to that of the products of breeding. In 1904 it is higher.

independent of the home market. Martin de Moussy says, it is true, that the area which sent the products of breeding to Europe in 1865 extended as far as the Sierra de Córdoba. But this statement needs correction. The hides from the whole of this zone were, in point of fact, sent down to the ports on the Rio de la Plata, but live animals were sent to Chile from the whole of the north-west of the Pampean region. It was for the purpose of selling cattle to Chile that ranches were multiplied about 1860 in the neighbourhood of Villa Mercedes and lower down, on the Rio Quinto. Jegou's 
description shows that even in 1883 the breeders of the San Luis province devoted themselves exclusively to supplying the Chilean market. ${ }^{x}$ Buyers from Chile and the Andean provinces still visit Villa Mercedes, and until a recent date they came to Villa Maria, in the province of Córdoba. The Santa Fé ranches found their customers, until the opening of the Córdoba line (I870) amongst the troperos, who bought draught oxen for their waggons. The loss of these customers and the crisis that followed are one of the reasons why agricultural colonization met with so little resistance on the part of the breeders, and was able to take root so easily at Santa Fé. In the San Cristobal department the breeders who settled there after I89o found their first market in the obrajes of the neighbouring forest. The opening of the railway to Tucumán afterwards enabled them to send their cattle to the provinces of the north-west. The Buenos Aires buyers were late in this remote canton of the Pampean plain. They did not arrive until IgII.

The importance of the Pampean region itself as a market of consumption grew in proportion to the increase of its population. The extent to which it absorbs the products of breeding and agriculture varies a good deal. For some of them it is paramount. Horsebreeding, for instance, which is still one of the great industries of the Pampa, has never contributed to the export trade. It is the same with regard to potatoes, which are concentrated in two strictly limited districts, round Rosario and north of the Sierra de Tandil. Only a small part of the dry fodder is exported. As regards cereals, a comparison of the statistics of production with the statistics of export shows that the home consumption is about one-third of the production. It is almost nil for flax, and nearly fifty per cent. for wheat.

I A. Jegou, "Informe sobre la provincia de San Luis," Ann. Soc. Cientifica Argentina, xvi. 1883, pp. 140-152, 192-200, and 223-230. 


\section{THE PLAIN OF THE PAMPAS}

The average of production and export for the years I9I2, I9I3, and I9I4, in thousands of tons, is :

\begin{tabular}{|c|c|c|c|c|c|c|}
\hline & & & Wheat. & Maize. & Flax. & $\begin{array}{c}\text { Total } \\
\text { (including Oats) }\end{array}$ \\
\hline Production & & .. & $4,24 \mathrm{I}$ & 6,398 & $93 I$ & 12,662 \\
\hline Export & -. & .. & 2,140 & 4,227 & 790 & 8,038 \\
\hline
\end{tabular}

As the chief centres of consumption are the ports themselves, it follows that the commercial currents that have to supply them are confused with the currents which maintain the exports. The exchanges between the various regions of the Pampa are more interesting to the geographer. In their tendency to specialize, these regions have ceased to be self-contained, and they have to look to adjoining regions. The feeding of the mills necessitates the transport of wheat in different directions. The chief mills are at Buenos Aires, where they are suitably located to work both for the home market and for export ; and the mills in the interior have some difficulty in competing with them. Some of these, however, are still active. They mix hard wheat, bought in the district of the Santa Fé colonies, with the soft wheat that is grown in the middle and south of Buenos Aires province.

But this inter-regional transport of cereals is a small thing in comparison with the transport of cattle. The extension of the lucerne farms has developed the fattening industry in many districts, while others still confine themselves to breeding in the ordinary sense, and they feed the other centres. The most specialized fattening district is that of Villa Mercedes and the western part of the lucerne belt, while the eastern part of the province of Buenos Aires and Entre Rios are still areas of production. The differentiation of the pastoral zones can be gathered from a study of the statistics. According to the I908 Census, milch 
cows represent 53 per cent. of the whole of the cattle in all the departments which form the heart of the breeding area east of Buenos Aires, and only 45 per cent. in the departments of the north-west of Buenos Aires and south of Córdoba and in the Pedernera department of San Luis, where fattening is common.

According to the I9I4 Census oxen are 24 per cent. of the herd in the same departments of eastern Buenos Aires ; 24 per cent. also in Entre Rios ; and the proportion rises to $3 \mathrm{I}$ per cent. in the lucerne area. Dolores department (eastern Buenos Aires) has 64 per cent. milch cows and 2I per cent. oxen. Pedernera department (San Luis, in the lucerne area) has 49 per cent. cows and 38 per cent. oxen. General Roca department (Córdoba) has 48 per cent. cows and 34 per cent. oxen. Arenales (Buenos Aires) has 39 per cent. cows and 46 per cent. oxen. ${ }^{\mathrm{I}}$

Oxen intended for the refrigerators are bought either on the ranches or at Buenos Aires, where beasts in good condition are consigned to buyers, but oxen for fattening are bought at fairs which are held periodically in the towns of the interior. Another transaction at these fairs is the trade in pedigree breeders. The best known of them is held at Villa Mercedes (province of San Luis), where 8,000 oxen are sold every month. At the Mercedes fairs one may see Durham steers from the east of Buenos Aires which are to be fattened and sent back to the refrigerators or the slaughter-houses of Buenos Aires. There are also creole cattle from the north of the San Luis province and Rioja which will later be eaten in Mendoza or in Chile. There is, in fact, on the western frontier of the Pampa no line of demarcation corresponding to that set up in the north by the limit of the area contaminated by the garrapate, separating the district of creole breeding from that of selective breeding. There is free communication here between the two

For Argentina as a whole the percentage is : milch cows, 55 per cent.; oxen, 26 per cent. 


\section{THE PLAIN OF THE PAMPAS}

zones, and the lucerne fields for fattening at Villa Mercedes are used in common by the breeders of the Pampa and of the bush. ${ }^{x}$

Cultivated Areas in the Argentine Republic

(in square kilometres, almost exclusively in the Pampean region).

\begin{tabular}{rr|r|r|r|r|r}
\hline & & Wheat. & Maize. & Oats. & \multicolumn{1}{|c|}{ Flax. } & Lucerne. \\
\cline { 3 - 6 } & & & & & \\
1896 & $\ldots$ & 25,000 & 14,000 & - & 5,600 & 8,000 \\
1900 & $\ldots$ & 33,000 & 12,000 & - & 6,000 & 15,000 \\
1902 & $\ldots$ & 36,000 & 18,000 & - & 15,000 & 17,000 \\
1905 & $\ldots$ & 56,000 & 22,000 & 700 & 10,000 & 29,000 \\
1910 & $\ldots$ & 62,000 & 32,000 & 8,000 & 15,000 & 54,000 \\
1912 & $\ldots$ & 69,000 & 38,000 & 12,000 & 17,000 & 59,000 \\
1913 & $\ldots$ & 65,000 & 41,000 & 11,600 & 17,000 & 66,000 \\
1914 & $\ldots$ & 62,000 & 42,000 & 11,400 & 17,000 & - \\
\hline
\end{tabular}

Exports for I9I3, 1914, and I9I5 at each port.

\begin{tabular}{|c|c|c|c|c|c|c|}
\hline & Wheat. & Maize. & Flax. & Oats. & Totals. & Average. \\
\hline & 782 & 1,757 & 275 & 13 & 2,829 & \\
\hline \multirow{3}{*}{ Rosario .. } & 242 & $1,95^{2}$ & 248 & I & 2,445 & 2,716 \\
\hline & 717 & 1,790 & 366 & - & 2,875 & \\
\hline & $44 \mathrm{I}$ & $1,3^{89}$ & 246 & 240 & 2,318 & \\
\hline \multirow[t]{3}{*}{ Buenos Aires } & 297 & 906 & 255 & 78 & 1,537 & 2,051 \\
\hline & 5 I I & I,349 & 342. & 96 & 2,299 & \\
\hline & 927 & 2 & - & 462 & 1,393 & \\
\hline \multirow[t]{3}{*}{ Bahía Blanca } & $24 I$ & 一 & - & 222 & 463 & 1,075 \\
\hline & 921 & - & - & $44^{2}$ & 1,364 & \\
\hline & 5 & 910 & 74 & - & 989 & \\
\hline \multirow[t]{3}{*}{ S. Nicolas. . } & I & 430 & 60 & - & 492 & $65 I$ \\
\hline & 5 & 420 & $4^{8}$ & - & 474 & \\
\hline & 333 & $35^{8}$ & I4 & I 70 & 876 & \\
\hline \multirow[t]{3}{*}{ La Plata .. } & I6o & $5^{I}$ & I6 & 49 & 278 & 459 \\
\hline & 152 & 45 & 6 & I6 & 222 & \\
\hline & 265 & $5 \mathrm{I}$ & 158 & - & $47^{6}$ & \\
\hline \multirow{2}{*}{ Santa Fé .. } & 7 & 23 & 128 & 一 & I 59 & 278 \\
\hline & I I 4 & 7 & 77 & - & โ99 & \\
\hline
\end{tabular}

I A large number of the cattle which are to be fattened are bought at the market in Buenos Aires; but these do not, as a rule, come from the Pampean region. 


\section{ROADS AND -RAILWAYS}

Roads on the plain-The salt road-The "trade route"-Transport by ox-waggons-Arrieros and Troperos-Railways and colonization-The trade in cereals-Home traffic and the reorganization of the system.

THE chapter devoted to primitive breeding and the transport of cattle contains a sketch of the network of routes over the Andes. One cannot expect to find in the scheme of routes over the Argentine plains the stern and obvious influence of natural conditicns. The surface of these plains is, as a whole, broadly open to traffic. Still, the map of the roads bears much evidence of geographical exigencies.

The hills which rise like islands out of the alluvial plain are not all incapable of being crossed, and the roads do not always skirt them. The road from Buenos Aires to Peru runs north of $30^{\circ} 40^{\prime} \mathrm{S}$. lat. on the very axis of the granite peneplain which forms the northern part of the Sierra de Córdoba. The Dean Funes ridge, which begins with an altitude of 2,500 feet between the Sierra Chica and these tablelands, has always been used for communication between Córdoba and the north-western provinces. There the railway has taken the place of the primitive track. Another important track crosses the Sierra de Córdoba in the north of the Pampa de Achala, and used to join Córdoba with Villa Dolores and the north of the San Luis province. The southern part of the Sierra de Córdoba and the Sierra de San Luis are, on the 
other hand, an insurmountable obstacle, which diverts southward the high road to Chile via Achiras, Sar José, del Morro, and San Luis.

The sierras of the Buenos Aires province are not so high and extensive. They are, moreover, broken into isolated hills with the plain passing between them. As early as 1822 Colonel Garcia pointed out the importance, in connection with the migrations of the Indian tribes, of the passage between the Sierra Amarilla and the Sierra de Curaco, that is to say, the Olavarria ridge. It is there that the first railway between Buenos Aires and Bahía Blanca crosses the line of sierras. It then skirts the Sierra de la Ventana, to the north, by the Piguie ridge, between the mass of Curumalan and the Puan hills. The dunes of the western Pampa also are an impediment to traffic, not so much because of their height as because of the looseness of the ground. The strip between General Acha and Toay was very trying for the stage-coaches. Travellers had to cross the dunes on foot during the winter season, when the horses were in a bad condition. ${ }^{\mathrm{I}}$

Natural supplies of water increase in number as one gets away from the Andean zone toward the east. Still, the chief work, often the only work, to be done in making a road is the arrangement of permanent supplies of water. Martin de Moussy mentions the digging of wells on the new road from Córdoba to Rosario, which was opened about 1860. The aiguade was generally a represa, a reservoir, where the water accumulated behind a barrier of earth raised across the course of an intermittent stream. The upkeep of the represa is the chief duty of the post-master. The edge of the sierras and the opening point of the ravines which come down them is a good place for making represas, and the roads frequently keep to these (variant

× J. B. Ambrosetti, "Viaje a la Pampa central," Bol. Instit. Geog. Argent., xiv. 1893, pp. 292-368. 


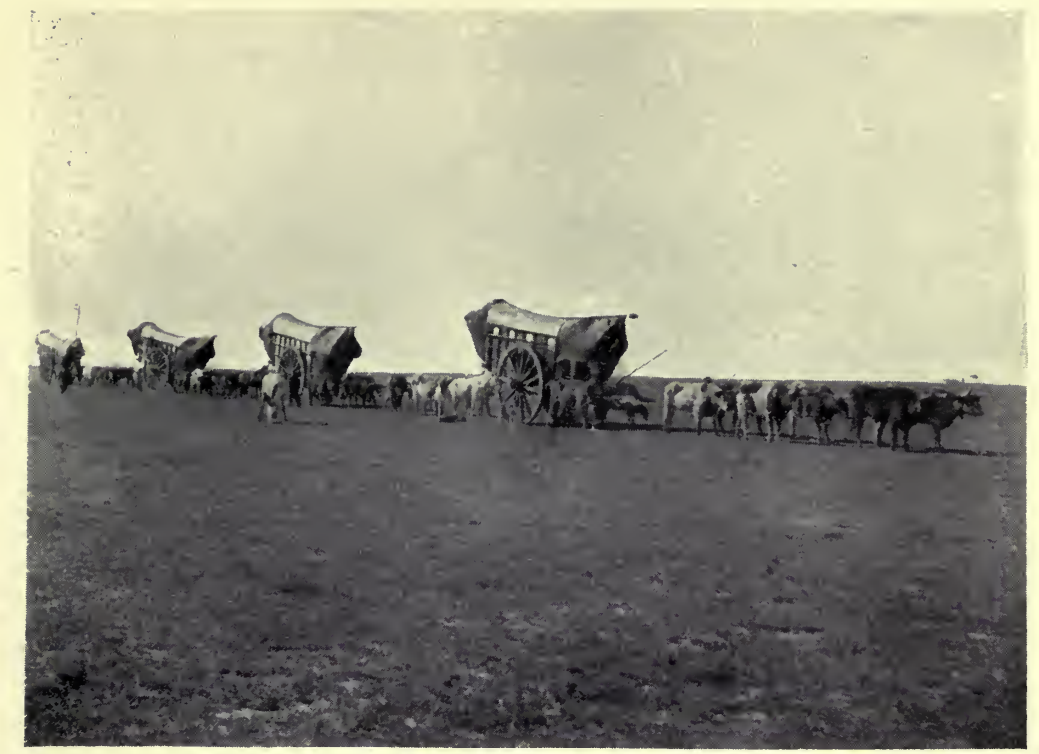

AN OX WAGON.

Photograph by Soc. Fotografica de Aficionados.

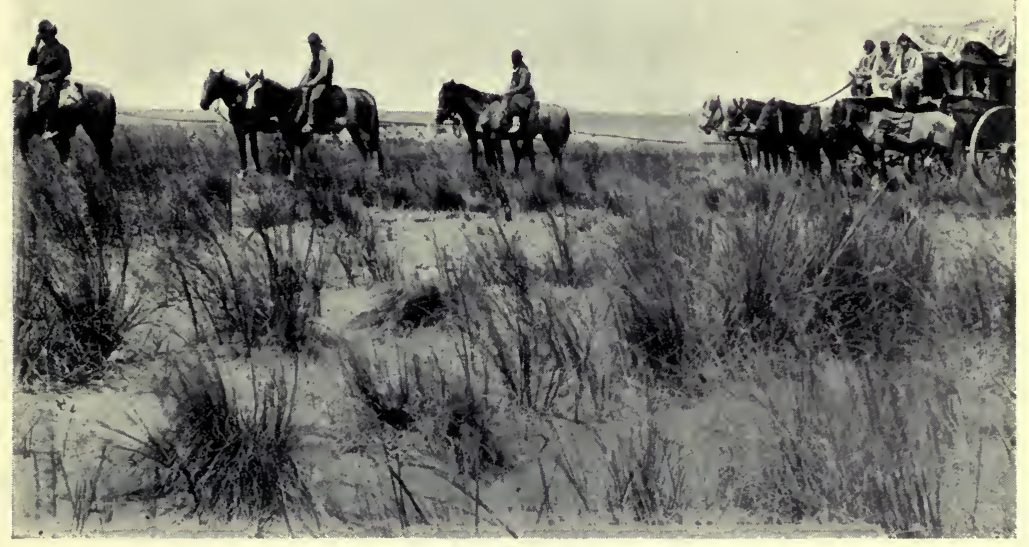

THE MAIL COACH.

The horses saddled with the cincha.

Photograph by Soc. Fotografica de Aficionados. 

of the road from Córdoba to Tucumán via Totoral, Dormida, Rio Seco and Sumampa, on the eastern edge of the Sierra de Córdoba, etc.) Long stages with no water supplies, the travesias, are not found on the made roads, as a rule, except west of the meridian, of Córdoba. However, the direct road from Santa Fé to Santiago del Estero by the lagoon of Los Porongos, which was used in the eighteenth century, seems to have been abandoned afterwards, as much on account of the difficulty of supplying water as because it was exposed to attack from the Indians.

The only difficulty which the caravans encountered on the roads over the plain was the crossing of the rivers. They were forded. Fords with a muddy bottom on the lower course of the rivers, such as that on the Saladillo near the confluence of the Rio Tercero, were more difficult for wagons than the fords with sandy bottoms in the upper course, near the fringe of the mountains, such as those of the Rio Tercero on the Córdoba road, or of the Rio Cuarto on the road to Chile. After rain, certain parts of the plain are flooded and impassable. That is the case in the district to the south of the lower Salado, at the very spot where Père Cardiel notices the lack of water in the dry season (I747). The direct road from Buenos Aires to the sierras was at that point exposed, alternately, to drought and flood. The line of the Southern railway, which crosses this low district, is still cut periodically on both sides of Las Flores by floods. The lack of an organized network of streams, the irregularity of the rains, the difficulty of ascertaining the inclination, and the flow of the waters over a plain which seems to the eye to be perfectly level, have led to more than one miscalculation on the part of the railways, which were constructed hurriedly, and before the general survey of the Pampa was finished. Some lines, on the Pampa or on the Chaco, 
have had to be partially reconstructed, and raised higher, after a series of rainy years. ${ }^{\mathbf{I}}$

The colonization of that part of the plain which actually constitutes the province of Buenos Aires was late. It belongs to the era of the railways. There is only one historic road crossing this area, which remained until the last third of the nineteenth century in the hands of the Indian tribes. This is the salt road. We do not know exactly when it began to be used. In the eighteenth century, in spite of the competition of salt from Cadiz and Patagonia, imported by sea, the Pampa salt was the main part of the supply of Buenos Aires. The salt road was not abandoned until after I8ro. We still have the diary of several journeys from Buenos Aires to the salt-pits. They were military expeditions. Hundreds of wagons, with a strong escort, collected at Lujan and Chivilcoy, and they reached Atreuco, west of the Guamini and Carbuë lakes, after a fifteen to twenty-five days' march.

The itinerary was fixed in detail. In I796 D'Azara noticed the wells sunk by the salters, north of the Palentelen lagoon (Bragado), when they found the lagoon dry. From Palentelen south-westward the salt road followed the track used by the Indians of the south-west in their expeditions against the ranches of the Buenos Aires frontier. Near Lake Epecuen, north of Carbuë, it was joined by another track which came from Olavarria, the stages of which were marked by the streams that came from the Sierra de Curumalan. The Carbuë district, the cross-roads of the

I Certain duplications in the actual scheme of the railways are due to this need to correct a line that had been planned hastily and was useless. The line from Justo Daract to $\mathrm{La} \mathrm{Paz}$ (1912), on the Pacific railway, avoids the steep inclinations of the first line, which followed the course of the wagon-road via San Luis. The interpretation of the relief is particularly difficult in a country which has not been shaped by normal erosion. Blunders detected by later topographical inquiries were similarly committed in constructing the Patagonian railways. 
tracks, was one of the places where the tribes collected. "This place," says the diary of the 1778 expedition, " is the first point where the hostile Indians meet and rest when they leave the Sierra and on returning from their invasions. They not only rest there, but have their winter pasture there" (in the dry season).I Zeballos has described the Indian track, the rustrillada, between Epecuen, Atreuco and Traru Lauquen, where the travesia on the road to Chile began. ${ }^{2}$ It was not less than $I, 000$ feet in width. At the foot of the dunes there were deep parallel grooves made by the feet of the raided cattle, which were taken away by the " Chileños."

The two main roads of the colonial period are the roads to Chile and Peru. On leaving Buenos Aires there was one road for a distance of about 320 miles. The "trade road" passed through Lujan, Areco and Sauce, and reached the Carcaraña, or Rio Tercero, at Esquina. It therefore kept at some distance from the Paraná (32 to 16 miles), on the tableland, crossing the valleys which were embedded in it and represented so many bad parts. It then ascended the Tercero on the right bank as far as the Paso Fereira, at the spot where Villa Maria is to-day. At Esquina de Medrano (Villa Maria) the road to Chile branched off to the south-east, reached San Luis by following the Rio Cuarto, going through Achiras and San José del Morro, and, after a travesia seventy-eight miles in length, came to the Rio Tunuyan at $\mathrm{La} \mathrm{Paz}$, and ascended the river to Mendoza.3

Coll. de Angelis, v.

- Est. Zeballos, Descripcion amena de la Republica Argentina, vol. i, "Viaje al pais de los Araucanos" (Buenos Aires, 1881).

3 Martin de Moussy says that a more direct route, avoiding the detour to the north by the Rio Tercero, was followed in the eighteenth century between Buenos Aires and San Luis, by way of Salto and the Rio Quinto as far as the latitude of fort Constitucion (Villa Mercedes). Woodbine Parish's map (1839) and Napp's map (1876) both show a road by way of Salto and Melincue to the Rio Cuarto, where it joins the ordinary road. However that may be, these roads were 
From Esquina de Medrano the Peru road made for Córdoba in the north-west. From the tablelands which continue the Sierra de Córdoba northward it descended toward the Rio Dulce, which it reached west of Atamisqui, and which it followed as far as Santiago del Estero, where it crossed to the north bank. It crossed the Sali in the latitude of Tucuman, and, passing through Tracas and Metan, followed the depression which separates the Andes from the subAndean chains. From Salta it went north to Jujuy, and passed through the Quebrada de Humahuaca to reach the Puna.

The influence of rivers is not much seen in the scheme of the primitive roads. There were in the sixteenth century many routes from Peru to the Paraguay, across the Chaco, but not a permanent road in the strict sense. In the eighteenth century there was a direct road from Santa Fé to Tucumán, by the north of the Los Porongos lagoon and the course of the Rio Dulce. There was another from Santa Fé to Córdoba. These roads were not exclusively used for conveying cattle. The river route which they joined at Santa Fé provided them with a certain amount of traffic coming from the higher provinces. Paraguayan maté reached the Andean regions by this road, and in return the boatmen at Santa Fé loaded up with the wines and dried fruit of the Andean provinces to take to Asunciôn.

The question of joining the road on to a river was not of very great importance until the time when the Paraná began to be used for Argentine imports and exports, and to maintain the communication of the interior provinces with Europe. This question of connection with a river controls the history of the

never used regularly, from fear of the Indians or-which comes to the same thing-because the area they cross, in the south of the actual territory of the provinces of Santa Fé and Córdoba, was not yet colonized, 
construction of the railway system. But the great importance of it can be seen from the first half of the nineteenth century. D'Orbigny had a presentiment of it. Speaking of the future of Santa Fé, he says: "When peace is restored, it is certain that the wares of Córdoba may, instead of going by land from that town to Buenos Aires, be sent to Santa Fé, where shipping them to the Argentine capital will reduce to one-third the journey by land, which is always more costly than going by water." Martin de Moussy, foreseeing the making of a road across the Chaco from Tucumán to the Paraná, in the latitude of Corrientes, calculates that Corrientes may later serve as port for part of the west and north of Argentina. At the date of the publication of his book, however, it was neither Santa Fé nor Corrientes, but the new town Rosario, that began to play the part of interior port, and led to the construction of a new system of roads. Traffic between Rosario and Córdoba at first followed the old road from Buenos Aires to Peru, which one struck after leaving Rosario and making a detour to the south-west, on the right bank of the Carcaraña (at Rio Tercero). But this itinerary was presently replaced by a direct road to the west-northwest, following the line which the railways would adopt. ${ }^{x}$

In the greater part of Argentina transport was by

- Between 18.52 and 1862 , during the period when relations were suspended between the Argentine Confederation and Buenos Aires, there was a beginning of a general reorganization of the roads in harmony with the new political conditions. The road from Santa Fé and Paraná to Concepción (in Uruguay) across the Entre Rios tablelands, and from there to Montevideo, had owed its initial importance to the closing of the lower Parana under Rosas, and Woodbine Parish records that there was already a good deal of smuggling there. This road became an essential artery when Parana made itself the federal capital under Urquiza. He intended to connect Paraná with the western provinces, and he created a mail service from Santa Fé to Córdoba. Ephemeral as the good fortune of Paraná was, its influence on the organization of the roads of Argentina was too material to be ignored by the geographer. 
means of wagons before railways were constructed. The limit between the area of wagon-transport and the area in which goods were conveyed on the backs of animals is quite stable. It is still of some significance, in spite of the development of the railways; wagons and mules are used at each station to collect and distribute goods. The area of farming and of selective breeding on the Pampa, the sheep-area in Patagonia, and the timber belt on the Chaco, still make use of wagons; and goods are carried on the backs of mules in the Andean area. The Peru road was, broadly speaking, fit for wagons as far as Salta, but it is rough between Tucumán and Salta, and wagons that used it generally stopped at Salta. In this way wagons avoided the ford of the Sali, which was easier for mules. On the plain itself the water-sources were often so distant from each other, and the stages so long, that mules had to be used instead of wagons. Wagons could easily get to Mendoza by the road along which the Tunuyan runs at its driest section, but all the convoys from Córdoba to San Juan, or Rioja to Catamarca, were composed of mules. Hence Córdoba was, like Tucumán, a station for changing on the road from Buenos Aires to the north-west. Lastly, while the scrub presented no insuperable obstacle to wagons, they could not enter the humid tropical forest, where the soil never dries. On the fringe of the Misiones forest, the wagons that came from San Tome unloaded at San Javier, and mules took the goods on to the yerbales.

The two areas of different kinds of transport were not sharply distinct. The muleteers (arrieros) sometimes avoided the domain of the wagoners, and competed with them as far as the banks of the Paraná. In 1860 (Hutchinson) the muleteers carried about a fifth, in weight, of the goods from the interior to Rosario, and they got more than a third of the transport from Rosario to the interior. They had, how- 
ever, to offer to carry goods at two-thirds the price charged by the wagoners. It appears that this invasion by the muleteers is connected with a transportcrisis in the Andean area, which left a number of the San Juan muleteers without work. It did not last. By 1862 mule-back transport between Rosario and the interior was almost over.

The wagons of the Argentine plain have often been described by travellers. They were heavy vehicles, carrying I5O, sometimes I80, arrobes (I,725 to 2,070 kgs.), covered with a leather hood stretched on hoops. A long spur decorated with ostrich feathers was balanced on a ring fixed in the roof, and was used to guide the front pair of oxen. An earthenware pot containing water enough for each stage hung between the rear uprights. As a rule, three pair of oxen were yoked to it, one pair being in the shafts. At Corrientes it was necessary to cross the marshes and esteros, and a special type of wagon had been evolved. It had a sort of horizontal division forming an upper story, and the driver sat in this. Everywhere, on the Pampa as well as at Corrientes, the wheels were enormous; sometimes, as Darwin says, ten feet in diameter. They were, therefore, able to get through the bad parts. Mud was, as a matter of fact, the worst enemy of the convoys. The soil of the Pampa is clayey and soft in the districts near the river. As the road was not limited in width, the wagons turned to the right or the left when the ruts became too deep, and the track in time covered a broad belt of ground. This, however, could not be done in the vicinity of towns, where the traffic was concentrated. Buenos Aires came to be surrounded by formidable quagmires that dried up only in the summer. The paving of the streets and environs was becoming a problem of national importance when the construction of the railway began.

Wagons did not travel singly. The tropero, or 
contractor for transport, organized caravans. In peaceful districts, where no military escort was required, the convoys could be split up; they consisted, as a rule, of from fifteen to fifty wagons. Besides the six oxen yoked to the wagon, there had to be others for relief as well as horses for the staff. Usually they allowed ten oxen to each wagon; in exceptional cases twenty. ${ }^{\text {I }}$ The convoy to the salt-lakes in 1778 had no less than 12,000 oxen to 600 wagons. There was a driver to each wagon, but there had also to be drivers for the starting animals, and carpenters to make repairs. The leader of the caravan, the capataz, was generally a master-carpenter. He looked after the interests of the tropero. There were about three men to each wagon. The carreros were an original type, nomadic, and very different in costume and character from the gauchos (breeders) of the plain. At the close of the eighteenth century Buenos Aires had more than a thousand wagons employed in the traffic to Mendoza and Tucumán (Borrero).

The stages were rarely more than four or five leagues of five kilometres each (thirteen to sixteen miles). At this rate it took a convoy forty to fifty days to go from Buenos Aires to Mendoza, thirty days from Rosario to Tucumán, three months (with the necessary rests) from Buenos Aires to Salta. ${ }^{2}$ When water ran short, the journey might be greatly prolonged, as the animals could do less work, or not work at all if the

I According to the details given us by De Angelis (1837, Introduction to the Diario del viaje al Rio Bermejo de Fray Francisco Moritto, Coll. de Angelis, vol. vi) a convoy of fourteen wagons from Salta to Tucumán required three relays of oxen. The first, comprising a hundred animals, went from Salta to Tucumán; the second, of r $_{30}$ animals, went from Tucuman to the Buenos Aires frontier; the third (84 animals); went on to the capital. The first and last relays were hired animals, the second alone being the property of the tropero.

- Thirty days from Buenos Aires to Mendoza, and seventy days from Buenos Aires to Jujuy, says Barrero (F. Barrero, Descripcion de las Provincias del Rio de la Plata, end of the eighteenth century, published by the Ministry of Foreign Affairs, Buenos Aires, I9I1). 
aiguades had dried up. The season was a matter for consideration. In the Buenos Aires district the winter made the ground sodden and traffic difficult. Farther north, winter is the dry season, so that pasture was scarce, and it was difficult to feed the tropas. The summer had difficulties of its own. In January and February the floods of the Rio Dulce often made it impossible to cross the ford at Santiago. The carriers preferred to start from the northern provinces about the end of the summer, in April or May. The best season for leaving Buenos Aires was the spring, from August to November. In this way each tropa could make the double journey once a year.

There had been attempts to speed up the transport before the railways were made. The galera (diligence), with its swarm of horses harnessed with the cincha (saddle to which the lasso was attached), did not carry goods. It did not replace the convoy of wagons, but the tropilla of spare horses which travellers on the plain drove before them. The galeria went from Rosario to Córdoba in three days and to Mendoza in ten days, and from Côrdoba to Salta in fourteen days. About 1860 a quicker goods service was organized, light wagons drawn by mules replacing the ox-wagons. They made the journey from Rosario to Córdoba in six days. Similarly, on the Pampa, the ox-wagons had been replaced before I 889 by quicker wagons, drawn by horses, to convey wool from the ranches to the railway stations.

The cost of transport by wagon was, naturally, high. It also varied a good deal, but we cannot possibly go into these variations here. It will be enough to give, by way of illustration, the details which Hutchinson gives for the year 1862. The freightage was fixed either for a complete load of I50 arrobes (I,725 kgs.) or so much per arrobe (II $\frac{1}{2}$ kgs.). Conveying a load from Rosario to Córdoba cost forty to fifty piastres (eight to ten pounds). The 
cost of carrying an arrobe from Rosario to Mendoza was five to six reales (about two shillings to two-andsix); from Rosario to Tucuman nine reales (three shillings and fourpence); from Rosario to Salta eighteen reales (seven shillings and sixpence). The tropas were, therefore, quickly ousted by the railways. In a few places they made a very unequal fight against the railways. The Memoria del departemento de Ingenieros de la Nacion of 1876, quoted by Rebuelto, mentions the competition of the tropas with the Andino railway, opened from Villa Maria to the Rio Cuarto in I873 and to Villa Mercedes in 1875 . The merchants of San Juan and Mendoza continued to use them. The railway had to sign a contract with the troperos by which wagons were to bring goods as far as Villa Mercedes, where they could be entrained. The total freight was fifty Bolivian centavos (about two shillings) per arrobe from Mendoza to Rosario, and sixty centavos from San Juan. Of this the share of the railway was fifteen centavos.

The first Argentine railway was opened in I859, between Buenos Aires and Maron, a distance of about thirteen miles.

In 1870 the Argentine railways formed two independent systems. The first radiated fan-wise from Buenos Aires (Western line, open as far as Chivilcoy in I870, and Southern line, open as far as Chascomus in 1865). Farther north a line (the Central Argentine) started from Rosario, and reached Bellville in 1866 and Córdoba in 1870.

The political isolation of Buenos Aires between I852 and I862, during the time when the first concessions were issued, made upon the railway system an impression that would not be effaced until twentyfive years afterwards. It was not until 1886 that Rosario was connected by rail with Buenos Aires. The line to Mendoza and Chile, begun in 1870 


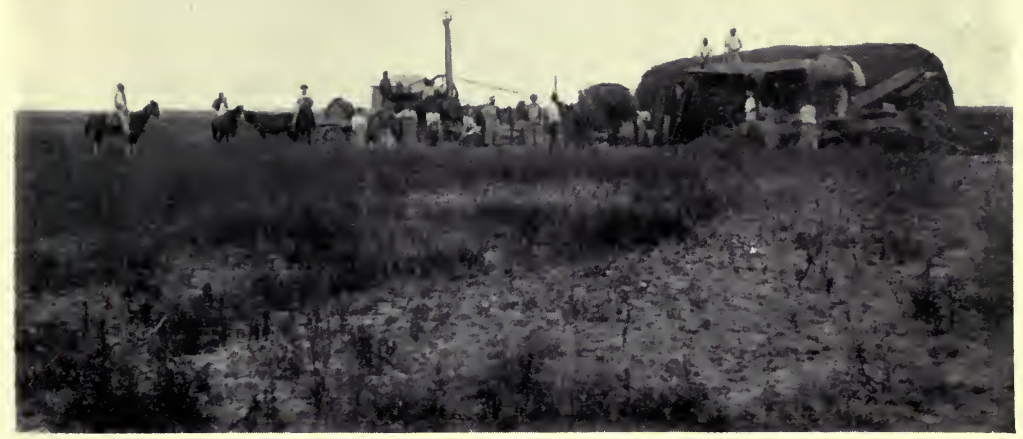

THRESHING ON THE PAMPA.

Photograph by Soc. Fotografica de Aficionados.

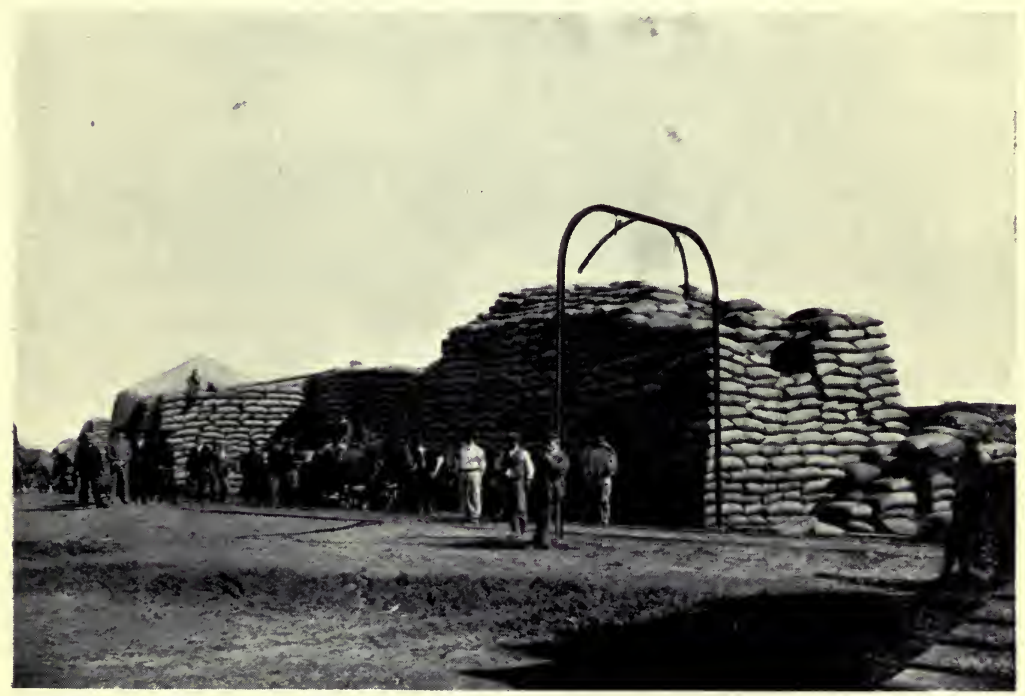

SACKS OF WHEAT READY FOR LOADING ON THE RAILWAY.

There are elevators only in a few of the ports.

Photograph by Soc. Fotografica de Aficionados.

Plate XIX.

To face p. 220 . 

(F. C. Andino), joins the line from Rosario to Córdoba. It reached Mendoza at the foot of the Andes before going on to Buenos Aires; and it was in 1888 that the Pacific railway was completed between Buenos Aires and Villa Mercedes, and established direct communications between the capital and the province of Cuyo.

The line from Rosario to Córdoba is, therefore, the chief branch round which the Argentine system developed. It is remarkable that at the time of the original concession in 1855 a westward extension was contemplated, and that there was some idea of making. it a stage in a trans-Andean. The first concessionaire, Wheelwright, had made the oldest railway in South America, from Caldera to Copiapo, in Chile in I85I. The 1855 concession authorized Wheelwright to extend the Cordoba line westward and link it with the Copiapo line. When he opened the Córdoba station in I870, Wheelwright, not suffering himself to be discouraged at the slowness with which the line had crossed the Pampa, still said that the goal was the Pacific, by way of Rioja, Copacabana and the San Francisco pass. This ambitious programme deserves to be recalled, if only as a reminiscence of the former orientation of the trade of Rioja and Tinogasta toward the Pacific, and as a proof of the importance, in the imagination of the men of that generation, of the old trans-Andean roads from north-western Argentina.

Even before the Rosario line had reached Córdoba, it had been continued northward as far as Tucumán. The work was pushed vigorously, and Tucuman was reached in 1875 . The Córdoba-Tucumán line was the first to be constructed entirely in the region of the scrub, and quebracho sleepers were then used for the first time. The earliest lines of the Buenos Aires province and the Argentine had, on the model of the Indian railways, a gauge of 5 feet 8 inches, but the Central Córdoba, from Córdoba to Tucumán, had a 
narrow gauge of forty inches. Hence goods coming from Tucumán had to be transferred at Córdoba. At the same time (1875) the line from Concordia to Monte Caseros was opened, and this made it possible to avoid the rapids of the Uruguay, which was to be a source of supply to the whole Mesopotamian system. Its gauge was fifty-seven inches. Differences of gauge are, and will continue to be, one of the characteristics of the Argentine system.

During the period from I875 to 1890 were constructed the main lines which took the place of the old roads from province to province. The Andean railway reached San Luis in $\mathrm{I} 882$ and Mendoza and San Juan in 1885 . Branches of the Central Córdoba reached Santiago del Estero in I884 and Catamarca in I889. In I89r the Central Argentine opened a new direct broad-gauge line from Rosario to Tucumán; and almost at the same time the narrow-gauge line of the Central Norte, from Santa Fé to Tucumán, was finished further north. The Tucumán line was continued northward to the foot of the Andes as far as Salta. In the province of Buenos Aires the Bahía Blanca line was opened in I884. Since I900 the railways have pushed on to the frontiers and are linked. in various directions with those of the adjoining countries. The Cumbre tunnel on the Mendoza transAndean was completed in I9I0, and traffic with Chile by rail is now permanent. The Salta line was continued in 1908 to the Bolivian tableland. In Mesopotamia, in fine, the north-eastern line reached Posadas in IgII and effected a junction with the Paraguay line.

These details, however, give a very imperfect idea of the history of the development of the Argentine railway system. It has not merely been superimposed upon the old roads, but has, on the other hand, helped to open up and develop new lands, which could not have been colonized without it. As early as I883 
Valiento Noailles, examining the general plan of the system, noticed the profound difference between the railways of Argentine and those of Europe. "In Europe," he said, "the railways are constructed to serve existing centres of production and consumption ... Our Argentine railways are to facilitate colonization." Corresponding to each occupation of a new area of the Pampean plain by the farmer or the breeder is the construction in that area of a new network of lines which are fed by its traffic and in turn help it to increase its production. The more productive the region is, the closer are the meshes of this network. They are wider in the pastoral than in the agricultural areas. The period of the development of the southern lines in the province of Buenos Aires corresponds with the expansion of breeding when the Pampa had been pacified. The railway reached Azul in 1876. The Ayacucho branch was opened in I880, and continued as far as Tres Arroyos in 1887. The completion of the Bahía Blanca line, via Azul and Olavarria, in I884, is itself merely one of the dates in this colonizing period. The great period of agricultural colonization at Santa Fé and the construction of the system of lines that serve it begin a little later, and last from I880 to I89o (extension of the Central Argentine system, the railways of the province of Santa Fé, and the narrow-gauge railway from Rosario to Córdoba).

The part that the railway has played in colonization is plainly seen in the present completion of the system which has developed freely on the even surface of the Pampean plain. The lines radiate round the port of Buenos Aires and, in a less degree, round the ports of Rosario and Bahía Blanca. What seems at first sight to be the symmetry of the railway map will be found on closer examination to be less perfect; while the Atlantic coast between La Plata and Bahía Blanca has no ports, the Paraná has quite a number of suit- 
able places for shipping cereals. La Plata, San Nicolas and Villa Constitución are served by lines which cut across the lines going to Rosario and Buenos Aires. This complexity of the system west of the Parana continues to the north of Rosario, where the lines that go to Santa Fé cut across all the lines going to Rosario. The lines which run along the southern frontier of the province of Buenos Aires (at Juancho, Necochea, etc.) have, unlike the lines serving the secondary parts of the Paraná, all their traffic directed toward the interior, and they serve only to bring to Buenos Aires and Bahía Blanco the crops of the districts they cross. They are dependencies of the main lines of the southern system, and not rival lines.

When the most fertile part of the Pampean plain, on which there is a regular rainfall to guarantee the crops, had been completely colonized and covered with railways, the national Government took up the policy of colonization by rail in the national territories. The minister Ramos Mejia has attached his name to this work. It has been suspended since the beginning of the war, but it filled the last period of construction of the Argentine railways. Ramos Mejia's railways include the lines penetrating the Chaco opened toward the north-west from Resistencia and Formosa, and the lines leading to the interior of Patagonia from the ports of San Antonio, Puerto Deseado, and Rivadavia. We must add the line from Neuquen to the Andes, made by the Southern Company, but with a Government subvention. ${ }^{x}$ These lines, serving districts with little population and inadequate resources, will not for a long time make any profit.2

I The line from Bahia Blanca to the Rio Negro, of which the Neuquen line is a continuation, was constructed in $\mathbf{1} 896$.

- The continuation of many of these lines was contemplated for the future, so as to secure for them at a later date a long-distance traffic. The Resistencia and Formosa lines, which reach the Andes, 
Hence railway construction must be regarded in modern Argentina as one of the aspects of the problem of developing the soil. The railway companies have been compelled to intervene directly in the work of colonization. In 1863 the Central Argentine received from the Government a strip of land three miles wide on each side of the line it was making, between Rosario and Córdoba, on condition that it colonized the land. The company had its own immigration agents and its colonizing staff, and it opened its first colonies west of Rosario between 1870 and 1872 . This kind of concession is exceptional in Argentina. On the other hand, the irrigation law of 1909 obliges the railway companies to undertake, on behalf of the Government, the work that is necessary to develop irrigation in the areas they serve, such work being immediately reflected in an increase of population and traffic. In compliance with this law the Southern railway is constructing a canal which will water the whole valley of the Rio Negro below the confluence of the Neuquen. The Central Argentine and the Pacific also have undertaken to construct dams on the Rio Tercero and Rio Quinto, in the provinces of Córdoba and San Luis.

As it is the essential function of a railway to convey the produce of the area it serves to the exporting port, the problem of the relations between the administration of railways and the administration of ports is of primary importance. The chief ports served by different companies, such as Rosario and

may compete for traffic with the Rosario and Tucumán lines. In Patagonia, the continuation across the Andes of the line from San Antonio to Lake Nahuel Huapi has been considered. A pass has been found at a height of 4,000 feet. When this plan is carried out, the Trans-Andean from Nahuel Huapi would be in a position to compete successfully with the Trans-Andean from Uspallata, which is condemned by its elevation to remain a passenger line. These plans, still far from realization, do not deprive the Ramos Mejia lines of their character as colonization lines, entirely devoted at present to conveying the timber of the Chaco and the wool of Patagonia. 
Buenos Aires, may maintain their independence, but a secondary port will be at the mercy of the single line which conveys goods to it. In such circumstances the ports have become, in many cases, mere dependencies of the railways. The port of Colastiné belongs to the railways of the Santa Fé province. The port of Bahía Blanca consists of a number of distinct ports constructed by the different railway companies, and run by them. Each of them ships the goods which it brings. The port Ingeniero White, which belongs to the Southern Company, was constructed in 1885 , immediately after the opening of the line from Buenos Aires to Bahía Blanca. Puerto Galvan belongs to the Pacific Company. Puerto Belgrano is the port of the line from Rosario to Bahía Blanca. At Buenos Aires the Southern Railway Company has acquired control of the Buenos Aires Southern Dock Company. At La Plata it manages the docks.

The spread of agricultural colonization was at first hampered by the cost of freightage which cereals could bear over an area with a radius of about 200 miles from the ports. That is the figure given by Girola in the Investigacion Agricola of Ig04. The period I895-I905 saw the birth of a series of plans for making canals in the Pampean region for the purpose of transporting grain in the area which the railway did not seem able to serve economically. Not one of them was carried out, but the railways quickly enlarged their sphere of influence in the interior. There is, however, a reminiscence of this pause in colonization in what Argentinians call " the parabolic tariffs." The Argentine railways practically, apart from cases of competition with rival lines, use proportional tariffs up to a distance of 218 miles, and degressive tariffs beyond that limit. In this way the railways have helped in the conquest of the west. Degressive tariffs have certainly played a part in the spread of colonization during the years antecedent to I9I2. They 


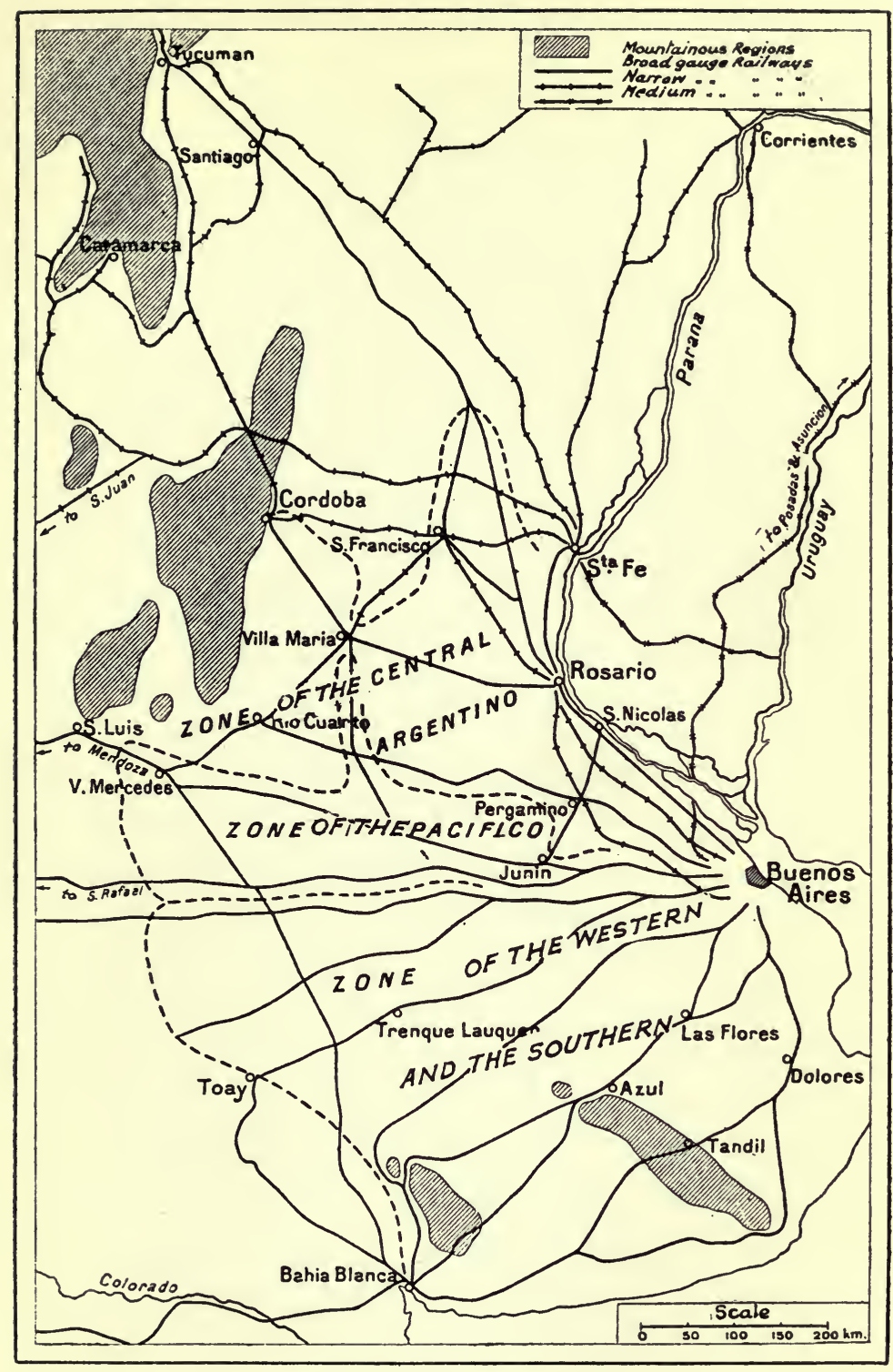

MAP VI.-THE RAILWAYS.

It is impossible to give the entire system. Only the main lines are given. Of the narrow-gauge lines of the Pampean region only those which connect the system of northern Argentina with Buenos Aires are given. The map shows the double direction of the Pacific system from Villa Mercedes, to Buenos Aires and Bahía Blanca. It gives only an imperfect idea of the way in which the lines ending at the ports of the Paraná and the Rio de la Plata (Santa Fé, Rosario, San Nicolas, Buenos Aires and La Plata) overlap and cross each other. 



\section{EFFECTS OF COMPETITION}

have helped to mask the inferiority of the new land to the better land in the east. ${ }^{x}$

The rise in the value of land and the advance of colonization led, at each of those crises of development which characterize the recent history of Argentina, to a multiplication of railway concessions granted by the national Government and the various provincial authorities. These have to be bought up by the leading companies, as each of them wanted to keep exclusive control of the region in which it had established itself. This concentration could not be accomplished in a perfectly methodical way, and the various systems now overlap, which is not to the interest of the companies. Thus Villa Maria, on the Central Argentine line from Rosario to Córdoba, is also served by a line belonging to the Santa Fé railways and by a line of the Pacific Company which puts it in communication with Buenos Aires. On the other hand, the Central Argentine penetrates to the very heart of the area of the Pacific at Junin.

However, competition between the various companies has had the effect of dividing the Pampean plain into three great spheres of influence. The first, in the north, is that of the Central Argentine and the Buenos Aires y Rosario line. In I908 the Argentine Government officially sanctioned the fusion of the two companies, though it had really been accomplished a few years before. The second sphere, in the south, is that of the Pacific, the attraction of which was the line from Buenos Aires to Villa Mercedes, and which in I907 bought the line from Villa Mercedes to Mendoza and the Trans-Andean, a natural continuation of its system. Moreover, in I904 the Pacific absorbed the line from Bahía Blanca to the north-west, which has been linked up once more with its original system at

× J. Lopez Mañan, El actual problema agrario (Buenos Aires, r9r2, Ministerio de agricultura, Direccion General de agricultura y defensa agricola). 
Villa Mercedes. It thus has two outlets, to Buenos Aires and Bahía Blanca, and completely encloses the third sphere with its branches. The third sphere, which comprises the centre and south of the Pampean plain, is the domain of the Southern and Western Companies. In I9I2 these two companies asked the Argentine Government to authorize them to amalgamate. Although they withdrew their proposal in I9I4, in face of the conditions imposed upon them, they are still closely associated. Part of the traffic of the western lines of the Western passes over Southern lines at Carbuë, and is shipped at the port Ingeniero White. At Buenos Aires also, and at La Plata, part of the Western Company's traffic in cereals and cattle uses the premises of the Southern Company. The Western and the Southern, jointly, bought in I908, before it was finished, the narrow-gauge Midland of Buenos Aires line at Carbuë, which was to cross their sphere of influence. It was opened in IgII.

The importance of the transport of cereals in the life of the leading Argentine systems will be seen from the following figures. In percentages of the total of goods carried, both from the interior to the ports and vice versa, the tonnage of exported cereals was:-

\begin{tabular}{lll|l|l|l|l}
\hline & & & I913 & I914 & I916 & Average. \\
\cline { 5 - 6 } & & & & & \\
Southern & $\ldots$ & $\ldots$ & $3 \mathrm{I} \cdot 0$ & $34 \cdot 3$ & $32 \cdot 5$ & $32 \cdot 6$ \\
Western &. & $\ldots$ & $53 \cdot 3$ & $6 \mathrm{I} \cdot 7$ & $55 \cdot 1$ & $58 \cdot 4$ \\
Pacific .. & $\ldots$ & $\ldots$ & $29 \cdot 0$ & $4 \mathrm{I} \cdot 8$ & $33 \cdot 8$ & $35 \cdot 0$ \\
Central.. &. &. & $36 \cdot 5$ & $46 \cdot 6$ & $34 \cdot 8$ & $39 \cdot 5$ \\
\hline
\end{tabular}

The figures are rather less for the Southern, which covers an area that has remained chiefly pastoral and, by means of its Rio Negro line, serves for part of the transport of cattle from Patagonia (cattletransport on the Southern, average for the years I9I3, 
I9I4 and I9I6: I7'2 per cent. of the total tonnage, I9 per cent. of total receipts; I*4 per cent. of tonnage and 6.5 per cent. of receipts). They are higher for the Western, the only system that lies entirely in the Pampean region and has no continuations beyond it, as the Pacific has to Mendoza and the Central to Tucumán.

The share of each company in the total traffic varies from year to year according to the harvest. Of the four to ten million tons of cereals carried every year, the greater part-about a third-falls to the Central Argentine, and one-sixth to the Southern. The Central Argentine carries the greater part of the maize and flax, the maize alone representing 26 per cent. of the total tonnage carried by the line, and the flax $5^{\circ} 6$ per cent. Of the other lines the Western alone carries any appreciable quantity of maize, which comes from the Junin district (I9 per cent. of its tonnage, but only I2 per cent. of its receipts, because of the slight distances the stuff is carried). The transport of wheat is about equally divided amongst the four leading lines, but the proportion of it to total traffic is highest in the case of the Western $\left(34^{\circ} 4\right.$ per cent. of total traffic). The Southern is the chief carrier of oats (9.8 per cent. of the total tonnage). The tonnage carried annually is particularly irregular in the case of the Central, on account of the irregularity of the maize crops, and the Pacific, because its lines northwest of Buenos Aires serve a wheat-area that is exposed to drought (wheat carried by the Pacific in I9I3, I5.9 per cent. of the total tonnage; in I9I4, $27^{\circ} 2$ per cent.).

The clearing of the cereals gives the Argentine railways a delicate problem in the organization of traffic. The crops of flax, wheat and oats must be cleared in the four to six months following the harvest (December-January). The maize harvest, which is later, is also much slower; it lasts the whole of the 
autumn. Hence the removal of the maize is spread over a long period, and sometimes the work of one year runs into that of the next. This gives the Central an advantage over the other lines. The wool also must, on account of its great value, be transferred to the ports speedily after the shearing; but this is only a matter of about a hundred thousand tons. ${ }^{\text {I }}$

Export, however, is by no means the one source of traffic on the Argentine railways. Transport of goods for home consumption is chiefly a question of a large part of the wheat crop. Building materials alsobricks, lime and stone-are an important item on the various lines which link Buenos Aires with the Sierra de Córdoba and the Sierra de Tandil. In I9I3 the Southern line carried I,I34,000 tons of minerals, including 997,000 tons of stone and IOI,000 tons of lime from the Sierra de Tandil and 34,000 tons of salt from the salt-mines of Lavalle, between Bahia Blanca and the Colorado. In the same year, the Pacific, Central Argentine, Central Córdoba and State railway carried 880,000 tons of minerals (half being lime) from the Sierra de Córdoba. ${ }^{2}$ All the timber carried on the lines of northern Argentina, except the quebracho from the banks of the Paraná, is for home use : sleepers, fence-posts, firewood and charcoal are the chief items on most of the lines in the scrub. The war has checked railway construction and reduced the use of sleepers, but it has also deprived Argentina of combustible minerals and increased the transport of firewood. Even on railways like the Pacific and Central Argentine, which have very few of their lines on the scrub, the tonnage of wood carried is 6 per

I The war and the difficulties of marine freightage have lessened the seriousness of the problem of carrying goods rapidly by rail in Argentina.

2 The transport of mineral stuff, apart from salt, has been greatly reduced by the war. In I916 it was only 637,000 tons for the Southern and 157,000 tons for the whole of the lines of the Central Argentine, Pacific, Central Córdoba, and State. 
cent. of the whole (average for I9I3, I9I4 and I9I6), and the proportion rises to 30 per cent. of the total tonnage on the Central Córdoba. For several companies the sugars of Tucuman and the wines of Mendoza are an important element of their receipts, not so much on account of the tonnage as the high cost of freightage and the great distance to the centres of consumption in the Pampean region. The carriage of wine and casks brings the Pacific 38.3 per cent. of its receipts (I9I3-I4-I6). The transport of sugar on the Central Argentine in a normal year amounts to 5 per cent. of its receipts. On the Central Córdoba the tonnage of sugar-cane and sugar carried amounted in I9I4, a year of exceptional harvest, to 42 per cent. of the total tonnage, and was still 20 per cent. in IgI6, a year of very poor crop. The supplying of meat to the market of Buenos Aires and the Pampean area, with its dense population, means a good deal of longdistance traffic in cattle; the refrigerators taking the better cattle of the adjoining region for the foreign market, and the slaughter houses of Buenos Aires being forced to content themselves with inferior beasts reared in the provinces and the adjoining districts.

The importance of these currents of internal traffic has made itself felt in the organization of the Argentine system. It has made it necessary for each system to have not only an outlet to an exporting town, but a direct connection with the chief centre of home consumption, Buenos Aires. The narrow-gauge system, which until the end of the nineteenth century had been restricted to the northern half of Argentine territory, north of the latitude of Rosario, developed in the province of Buenos Aires after I900, and ventured to compete in the carriage of cereals with the broad-gauge system (Company of the Province of Buenos Aires and Provincial railway of $\mathrm{La}$ Plata). This system connected with the narrow-gauge lines of the north. The Central Córdoba, which had reached 
Rosario in IgI2 and so had escaped the need to transfer its export-traffic at Córdoba to the broadgauge, began immediately afterwards to effect a direct communication with Buenos Aires (Central Córdoba, extension to Buenos Aires, opened in I9I3). The line from Rosario to Buenos Aires of the Province of Buenos Aires Company also serves to carry trains of the Province of Santa Fé Company, which is closely associated with it. The medium-gauge lines of Mesopotamia also have effected a communication with Buenos Aires by means of a ferry-boat that plies on the Paraná between Ibicuy and Zarate, and by using a section of the Buenos Aires Central.

The concentration of narrow-gauge and mediumgauge lines seemed to be issuing in a complete fusion of their interests in Igr3. The Argentine Railway Company got control of the lines of Entre Rios, Corrientes and the Paraguay. It promoted the development and extension of the Central Córdoba, and it also had large interests in the French companies of the Buenos Aires and Santa Fé provinces. All the narrow-gauge lines would have concentrated in its hands if it had been able to get the State railway. The broad-gauge line from Rosario to Puerto Belgrano had, as its interest conflicted with those of the great broad-gauge English systems, joined the narrow-gauge group engineered by the Argentine railway. But the amalgamation attempted by the Argentine railways did not succeed, and, after its failure, the companies it had temporarily brought together resumed their independence.

The river-route of the Paraná has sometimes been an auxiliary, at other times a rival, of the railways.

Until the line from Buenos Aires to Rosario was opened in I886, the navigation of the Paraná was the only link between the system of northern Argentina and that of the Buenos Aires province. Before the line was completed, the company had established a 


\section{RIVER AND RAILWAY}

service of boats on the Paraná, and in this way it kept up a traffic in goods consigned to stations on the Central Argentine, to be transferred at Rosario. These combinations of railway and river service disappeared when the line from Buenos Aires to Rosario was finished.

In regard to export traffic the railways have not attempted to compete with the river anywhere where it is open to maritime navigation; they have merely been concerned to connect with it. On the other hand, the railway and the river are rivals for the home traffic and the traffic of the upper districts which sea-going boats do not reach. Before the time of the railways the river had taken all the goods traffic, but had tolerated on its left bank a post-road between Santa Fé, Corrientes and Asunción. The railway still has the advantage over the river in regard to speed (in carrying passengers between Rosario and Buenos Aires, and live cattle from the Chaco and the Paraguay for Buenos Aires or the salting works of the lower Uruguay). Even in regard to certain kinds of heavy goods-quebracho timber-the river has not secured a monopoly, and there is a good deal of transport by rail. 


\section{THE RIVER-ROUTES}

The use of the river before steam navigation-Floods-The river plain-The bed of the Paraná and its changes-The estuary and its shoals-Maritime navigation-The boats on the Paraná.

The problem of the use of the river-routes of the Parana and the Paraguay is not of interest to Argentina alone. It affects the whole history of colonization in South America. The very name of the Rio de la Plata is a reminiscence of the anxieties of the early navigators who landed there, chiefly in search of a route to the mineral districts of the Andes [Plata $=$ silver]. It is remarkable that the Amazon, which opens a more direct and better route to the Andes, was never used for reaching Peru. It was at the most, and only occasionally, used as a returnroute, whereas expeditions to the Cordillera were organized on the banks of the Parana during the whole of the sixteenth century. The routes linking the Parana and the Paraguay with the tableland furrow the whole plain of the Pampa and the Chaco, from the latitude of the estuary to about $16^{\circ} \mathrm{S}$. lat.

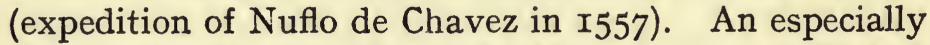
close network starts from the river between $18^{\circ}$ and $22^{\circ}$ S. lat. and ends at Santa Cruz, the most northern centre established by the Spaniards on the plain, at the foot of the Andes, as a consequence of the use of the Paraná. ${ }^{1}$

I There is still a certain amount of goods traffic in this latitude between the river and the Santa Cruz district by the Puerto Suarez and Puerto Pacheco tracks. 


\section{THE PORTUGUESE FORTS}

Spanish colonization, however, did not succeed in making permanent settlements on the Chaco. The Indians, who were masters of it, disputed their passage, and the only practicable route was the southernmost of the roads to the tableland, south of the Rio Salado, which ends at the estuary. From this time onward the prosperity of Buenos Aires eclipsed that of Asunción. The river ceased to be a great continental route.

The division of the Parana between the Spanish and the Portuguese was a check upon the full development of the river-route. The Portuguese held the upper part of its basin, which now belongs to Brazil. They expelled the Spanish missionaries from the upper Parana about the middle of the seventeenth century, and made themselves masters of the Paraguay north of $20^{\circ} \mathrm{S}$. lat. Their forts at Coimbre and Albuquerque prevented any from ascending. D'Azara insists that it would have been Spain's interest to disarm these forts ; it would have enabled them to go up the river as far as the Spanish missions to the Mojos and the Chiquitos. On their side, the Portuguese only used the upper section of the river, where it is joined by the Paulist road north of the Coimbre, as a means of access to the gold mines of the Matto Grosso. Even now, although the Paraná is open to every flag, the development of the river-route is not independent of political conditions. In making the railway from Saint Paul to Corumba, and so creating on its own territory a means of direct communication with the upper Paraguay, Brazil diverts from the lower districts part of the traffic which ought normally to go there. Again, the ports of southern Brazil and the lines which go to them try to attract to the Atlantic the produce of the basins of the Uruguay and the upper Paraná, which would have followed the thread of the river to foster the trade of Buenos Aires if the frontiers had been fixed otherwise. 
Before the Revolution the river-trade was confined to exchanges between the Misiones and Paraguay on the one hand, and Buenos Aires and the Andean provinces on the other. After the extinction of the missions Paraguay was the chief centre of traffic on the river. At the close of the eighteenth century it had a fairly large population. According to D'Azara, it amounted to 97,000 , and 47,000 for the area of the former Missions (Misiones), while Buenos Aires, Santa Fé, Entre Rios and Corrientes had not more than I03,000 inhabitants collectively. Paraguay exported tobacco, maté and timber by the river. The Buenos Aires Estano received 800 tons of tobacco a year. The exports of maté from Paraguay to Peru, Chile and the interior provinces amounted to 1,725 tons, and 2,250 tons went to Buenos Aires. The timber came mostly from the Tebicuary, where the angadas (loads of timber) were formed. The chief constructive sheds also were on the Tebicuary. Boats of twenty to 200 tons were launched there; and they had armed boats, when they went down the river, to detect ambushes of the. Indians, who were masters of the right bank north of Santa Fé.

The development of navigation on the Paraná during the first half of the nineteenth century was checked by the disturbances and wars of the period of the emancipation and unification of Argentina. The river was blockaded several times and traffic interrupted. Only a few smuggling schooners succeeded in getting through the side branches, which the ships stationed in the river could not watch. Robertson escaped the Spanish vessels in this way. The picture which D'Orbigny has given us of the life of the river belongs to the year 1827. At that time the estuary was blockaded by the Brazilian fleet in the whole area of the delta as far as San Pedro. Piracy was so rife, and the insecurity so great, on the Uruguay and the Paraná, that few ventured as far as Buenos 

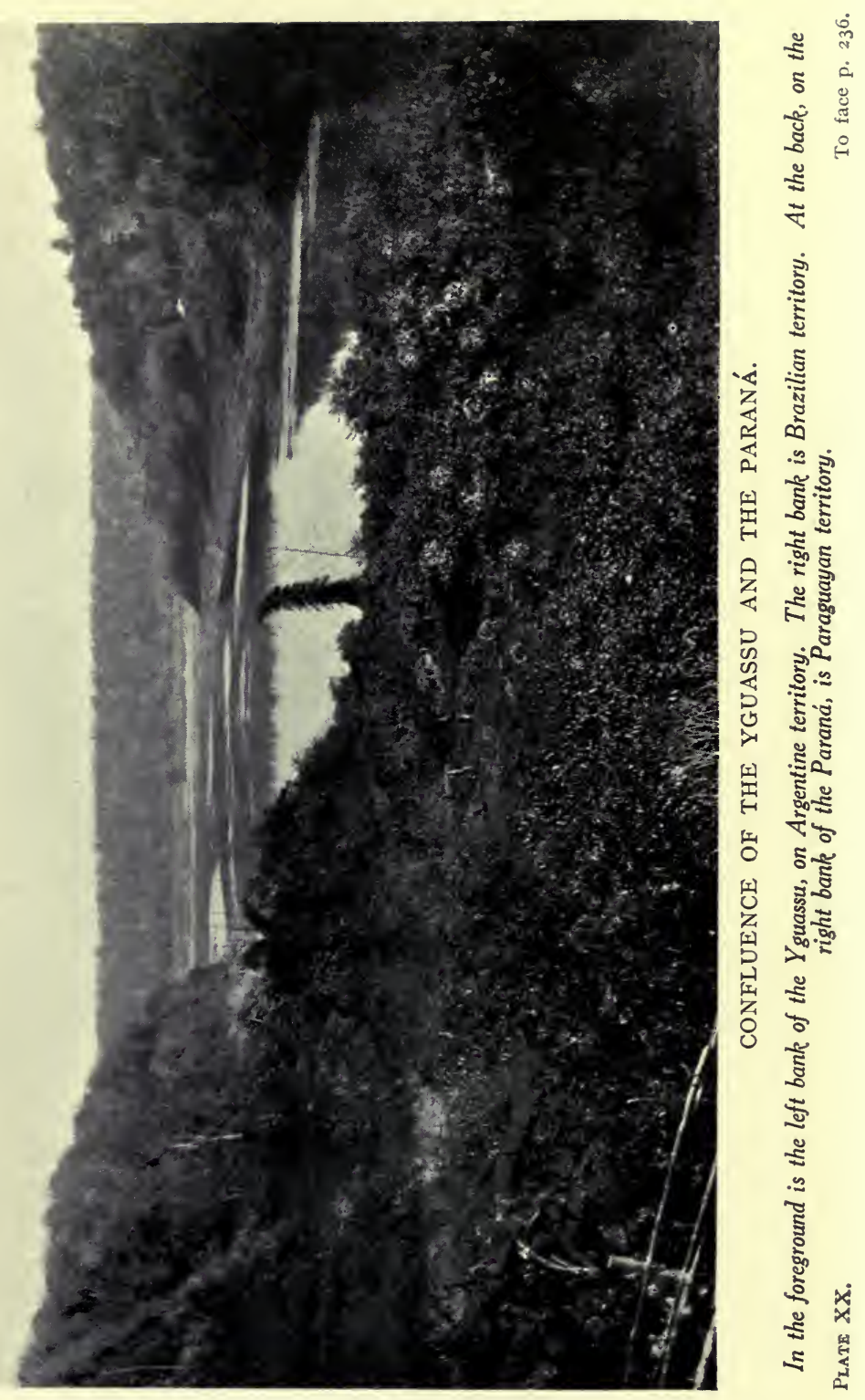

Aires, the ships being linked in convoys. Up stream, Corrientes was the limit of navigation. The dictator Francis closed the Paraguay, and even the small boats no longer sailed on the upper Paraná, along the frontier of Paraguay. The Correntinos, who spoke Guarani, could merely get permission at rare intervals to send a few boats up river. Armed boats convoyed these as far as Neembucu, and they returned with hides and maté. Corrientes thus became the market-centre of the upper river and replaced Asunción in the trade. The flotilla on the Paraná included flat-bottomed barges, which were only used in coming down, and strong keeled ships-schooners, sloops and brigswith their ropes made of leather. Down stream there was a little more diversity in the traffic. The island sent cargoes of firewood and charcoal to Santa Fé and Buenos Aires. The orchards of the delta provided Buenos Aires with oranges and peaches. Hides for export were shipped at Goya and Santa Fé. But the chief freight was lime from La Bajada, which was burned in the kilns on the Barranca, at the outcrops of the beds of conchiferous limestone.

The navigation was fairly easy, the journey from Corrientes to Buenos Aires (675 miles) lasting, as a rule, from fifteen to twenty days. Going up, the time was more irregular. They had to stop when there was no south wind, or a little progress was made by hauling (silgar). D'Orbigny took a month to travel up. ${ }^{1}$ In I822, before the war with Brazil, there were $65 \mathrm{I}$ boats entered at Buenos Aires for coasting trade on the rivers and r,035 at San Fernando or on the Tigre, the advance port of Buenos Aires. In I833 Isabelle put at one thousand the number of vessels at work on the Parana and the Uruguay.

I The local south winds which help the voyage upward below Rosario may be due to the high temperature of the water of the river; this also gives rise on the lower Parana to thick fog of which warning is given. 
In I84I Rosas forbade navigation on the river. There was then a double blockade checking the trade of Argentina. The Franco-British fleet closed the Rio de la Plata and blockaded Buenos Aires, where the Government of Rosas was established. In addition, Rosas's troops on the barranca of the right bank prevented any from going up the Paraná, and cut off the interior provinces from the rest of the world. The injury then done to interests which were already fully self-conscious may be gathered from the agitation provoked by the decision of France and England in I845 to break the blockade of the river. A convoy was at once organized at Montevideo, consisting of no less than ninety-eight ships, of 6,900 tons in all (MacKann). It went up the Paraná under the protection of warships, which removed the chains slung across it by Rosas. The convoy dispersed up river as soon as it was out of range of Rosas. But it had needed so great an effort that the attempt could not be made again before the fall of Rosas.

The closing of the Paraná compelled a diversion of the trade of Paraguay toward the south-east. It crossed the isthmus of Misiones, between the Parana and the Uruguay, and passed down the Uruguay. At this time the whole commercial activity of Paraguay was concentrated at Itapua, on the upper Paraná. The prosperity of the Uruguay was some compensation for the misery that reigned on the Paraná. The populations of Paysandu and Montevideo greatly increased.

In I852, at the fall of Rosas, the modern period began for the Paraná. The river-population changed rapidly. It ceased to be exclusively creole. Basques, and later Italians, had settled upon the Uruguay ten years before, and they now spread along the Paraná. In I850 MacKann found fifty vessels, of 20 to Ioo tons, belonging to Italians at Santa Fé. This wave of immigration coincided with the development of 


\section{DURING THE REVOLUTION}

relations between the Paraná and the port of Montevideo. From 1852 to I860 Buenos Aires was isolated, and it remained outside the economic life of Argentina. Montevideo took its place. Urquiza's administration sought, in addition, to establish direct maritime communication between over-seas ports and the ports on the river: Gualeguy in Entre Rios, and Rosario in Santa Fé. Under a system of preferential duties (I857-59), which reduced the burden on goods carried by the river, Rosario grew rapidly, and between 1853 and 1858 increased its population from 4,000 to 22,700 . The period from 1852 to 1860 was also the time when steam-navigation was developing, and this doubled the value of the river-route. From I860 onward Buenos Aires was connected by regular services of steamboats with Rosario, Santa Fé, Corrientes, Asunción and Cuyaba. On the upper Paraná goods (timber, tobacco and oranges) were still carried by sailing boats between Corrientes and Apipé, where they stopped at the commencement of the rapids. Steamboats did not sail up the rapids of Apipé until I868. I From I850 to I860 there were repeated explorations of the Salado and the Bermejo, as the interior provinces hoped to be able to find a connection with the vivifying artery of the Parana (voyage of Page on the Salado from Salta in 1855, and of Lavarello on the Bermejo in I855 and I863).

In 1860 the entry of Buenos Aires into the Confederation re-established the normal condition of free competition between Buenos Aires and Rosario. From that time the life of the river reflects the advance of colonization in the Pampean region. The Paraná became the highway for the export of cereals.

The two rivers, of which the Rio de la Plata forms the common estuary, differ considerably in their features. The Uruguay has irregular floods, especially

s According to Rengger, sailing ships sometimes succeeded in crossing the Salto d'Apipé. 
in autumn (May) and at the end of the winter (August-October). Low water is in summer (JanuaryFebruary). Its basin belongs to the temperate zone, and does not extend northward as far as the area of tropical summer-rain. The Uruguay also differs from the Paraná in its low capacity for transport and alluvial deposit. While the Paraná has built up a vast deltaic plain, the Uruguay ends in an ordinary estuary, with rocky or sandy bed and clear water. The estuary of the Uruguay is I30 miles long and five or six miles wide. The eastern shore is rocky and broken. The Argentine shore is low. It is formed in the south by the deposits of the delta of the Paraná, while further north, from Gualeguacha to Concepción, the hills of Entre Rios are hidden behind a screen of flat islands covered with palms, formed by the stuff brought by the streams of Entre Rios. The riverfloods are lost in the great sheet of the estuary. The tide in the estuary or a flood in the Paraná is enough to turn the current.

Maritime navigation goes beyond the estuary and beyond Paysandu, as far as the rapids which prevent further advance at Salto. The twin towns of Concordia (right bank) and Salta (left bank) mark the limit of navigation on the inner course of the river. It begins again above the falls, at Monte Caseros, from which the river-boats go to San Tomé and occasionally to Concepción. Small ships go higher, as far as Salto Grande in Misiones (27 $20^{\prime}$ S. lat.). ${ }^{\prime}$

The navigable system of the Parana is four times as large. The first survey of the river was made about the middle of the nineteenth century by the British Navy. At the beginning of the twentieth century the Argentine Government took up the study of the bed and the peculiarities of the Paraná, and

I At one time the boats on the upper Uruguay saved transport by going from Salto to Arapehy, midway between Monte Caseros and Concordia (see Isabelle). 
the Ministry of Public Works published a map, on the scale $I: I 00,000$, of the course of the river between Posadas and San Pedro, at the beginning of the delta. A precise survey was made, and twenty-six fluviometrical scales were established, the zero of which represents mean low-water. ${ }^{I}$ Transverse soundings were taken at equal distances of 670 and I,000 feet, the distance being reduced to 160 and even 80 feet at critical points. Thanks to this work, the Paraná is now, no doubt, the best known of all rivers of that size.

Its output is estimated at 6,000 cubic metres a second at mean low-water, in the latitude of Rosario, and 25,000 to 30,000 cubic metres a second during flood at a height of six metres above low-water. ${ }^{2}$ Its features bear the mark of its tropical origin. The tropical character is typical on the Paraguay, which is, by its situation in the central South-American plain, the real continuation of the lower Paraná. The slightness of the fall of the Paraguay, however, and the extent of the marshes over which it spreads in Brazil and Paraguay, have the effect of regulating and retarding the flood, which only attains its maximum at Asunción in May. The flood of the Paraguay extends the period of high water on the lower Parana until the end of autumn. The upper Paraná has most of its basin in the tropical zone of

It is as well to notice that the profile determined by the altitude of the zero of these different scales, or the low-water profile, is of a purely theoretical character. The river is never at low-water over its whole course. The real profile is always varied by slight movements of flood and ebb.

2 Observations of the sediment held in the water have been made at Campana, 32 miles from the estuary. At this point the Parana only holds in suspension fine particles of clay, but sand travels slowly along its bed. The weight of the clay in suspension varies from $\mathbf{I} 79$ grammes per cubic metre in March during the flood, to 42 grammes at low-water in July. The stuff mostly comes from the Bermejo, which carries 5 kilogrammes of sediment per cubic metre. The load of the Parana is much heavier than that of the Uruguay, but far lower than that of the Mississippi. 
summer rain. But its behaviour is also influenced by the spring or autumn rains of the southern part of the Brazilian tableland. Its floods are sudden and violent. They reach a height of sixty or seventy feet in the region of the confluence of the Yguassu. They sweep rapidly down stream, and reach the lower Paraná before the flood of the Paraguay, which they hold back.

From Posadas the flood-waves reach Corrientes in five days (235 miles). From Corrientes they reach Paraná in eight days (380 miles), travelling about two miles an hour. That is one-third the speed of the current, as the flood is retarded, and more or less absorbed, by the ramifications of the broader bed in which it moves.

At Bajada Grande the lowest water is in September. The flood appears in December or January, though sometimes in October or November. The maximum is in March or April. The rise is rapid at first, but it gradually moderates, and the level of the water is raised about one metre per month during three months. It then sinks in corresponding order. The $\mathrm{ebb}$ is often interrupted in June, and sometimes as late as August, by a sudden leap upward of the curve, representing an ascensional movement of the water three times as rapid as that of the main flood (one metre in ten days). The level reached in this late flood is sometimes higher than that of the normal flood in April or May. The range of the ordinary flood-movements is from ten to sixteen feet. Exceptional floods rise to a height of twenty-three feet above the low-water mark.

The curves established for the years I908 to I9Io by the Argentine hydrographical service enable us to analyse the mechanism of the flood with a good deal of confidence. The beginning of the flood at Bajada Grande in October corresponds to the first flood of the upper Paraná. During this first phase the curve 
of the Bajada is parallel (thirteen days later) to that of Posadas. There is the same parallelism in November, December and January. If the summer rains are light on the upper Paraná, the flood is late on the lower Paraná, and the water is still low there in December (0.20 below the low-water mark on December 3I, I9IO). At the beginning of March, before the maximum of the flood, the curve of Bajada Grande differs from the curve of Posadas. It is the time when the flood of the lower river is caused by the rise of the Paraguay. The secondary floods of June and July again have their origin in the upper Paraná, but, as they are added to the flood of the Paraguay on the lower river, they reach a higher level there than at Posadas; the difference gradually disappears as the flood of the Paraguay subsides. It is the addition of the late floods of the upper Parana to the flood of the Paraguay that causes on the lower river the abnormal floods that occur there at irregular intervals (in I825, I833, I858, I878, I905 and I9I7).

Below the Bajada the height of the floods progressively declines. On the estuary they are no longer perceptible; variations of level are due entirely to the tides. In the channels of the delta of the Paraná the tide does not reverse the current as it does in the estuary of the Uruguay, but it causes a slight rise of the water; and this has been observed sometimes, at very low water, as far as Rosario.

It is near Corpus, about forty miles above Posadas, that the upper Parana escapes from the restraint of the Brazilian tableland, which imprisons its valley, from the falls of the Guayra, in a deep fissure between lofty basalt cliffs. Below Posadas the river leaves the region of hills and red earth. Below Corrientes it flows everywhere over its own alluvia. Even above Corrientes its form has surprising characteristics of youth. The precise survey done on its banks has brought to light a very distinct break of its fall above 
Villa Urquiza, about 400 miles from Buenos Aires. The fall, which from Corrientes onward remains between sixty and forty millimetres per kilometre, sinks suddenly to thirteen over a stretch of twenty-five miles, and then rises again to thirty to forty-five millimetres. 1 Below Rosario the mean descent is twelve millimetres to the kilometre, below San Pedro only six.

Above Corrientes the width of the main arm of the Paraná varies, as a rule, from 2,600 to 6,500 feet. The width of the river-plain over which the floods spread is still more irregular. Between Santa Fé and Paraná, where it is especially narrow, it is still ten miles wide. Lower down it gradually broadens to a width of sixty-five miles at the head of the estuary. The scenery is not the same in all sections of it. The vegetation on the islands is richer and more varied up river, and tropical essences (laurel-timbo) are found below the Bajada, forming clumps of trees covered with creepers.

But the different scenes of the river region are most of all due to different conditions of erosion and formation. Above Rosario the configuration is due to floods. Each succeeding flood alters it and leaves some trace of itself in the topography. The beds of sand that it lays down are fixed by rushes and floating weeds, then by willows (Salix humboldtiana). This screen of vegetation encourages accretion, and the edges tend to rise higher. In the middle of the island are low, marshy lands. The irregularity of the alluvial deposits causes marked undulations in the whole region of the river, and everywhere gives rise

I The district on the right bank of the Paraná, above Santa Fé and Paraná, seems to be due to a recent subsidence. The river is, on the other hand, compelled to effect active erosion in crossing the high lands between Santa Fé and Buenos Aires. It is curious that the break or fall at Villa Urquiza occurs precisely above the bend of the Paraná. A less marked break has been recognized further north, in the latitude of Lavalle, above the Goya bend. It seems that the diminution in the excavation of the valley is due to the erosion which the current effects laterally on the cliffs of the left bank. 


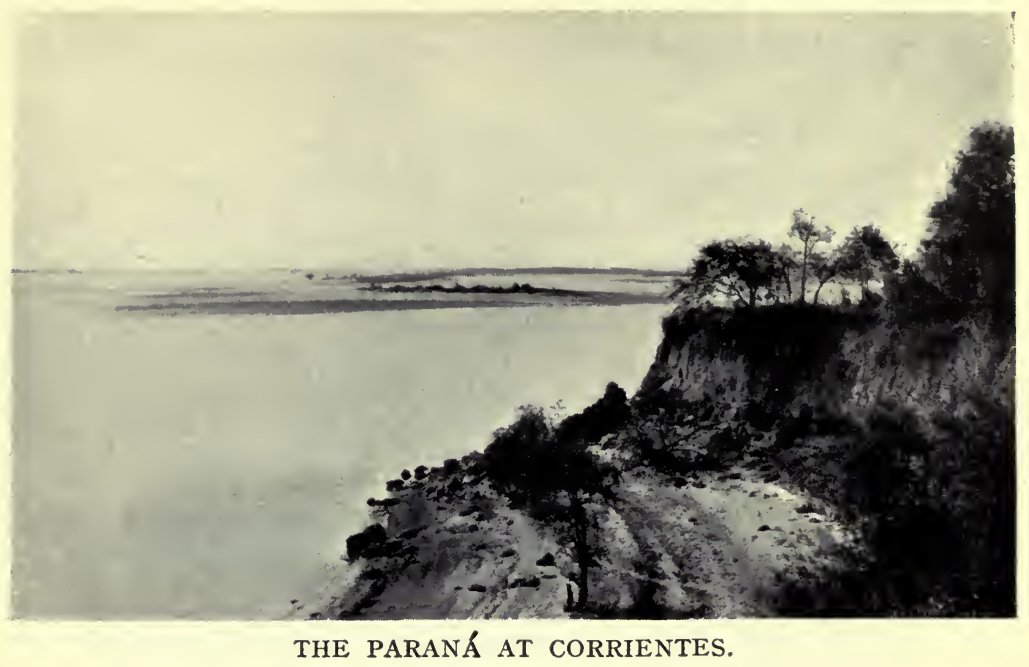

Banks and islands partially fixed by vegetation.

Photograph by Widmayer.

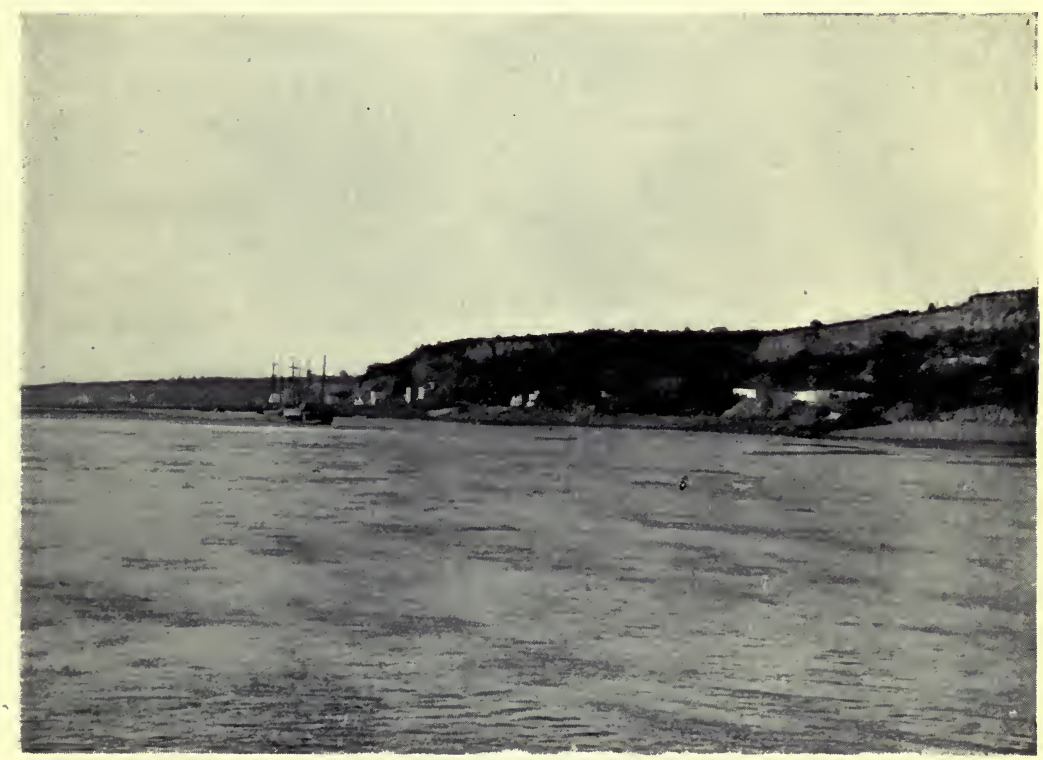

THE BARRANCA AT PARANÁ (ENTRE RIOS), LEFT BANK.

It is composed of clays and of beds of conchiferous terrestrial limestone, which have supplied the lime-kilns for more than a century. Plate XXI.

Photograph by Boote. To face p. 244 . 

to alternate beds of clay and sand. Below Rosario the river gradually loses its power. The islands become more stable and flatter. Clumps of willow and spiny ceibos (Erythrina cristagalli) still cover the edges of them, and sometimes spread over the interior. But as the climate is now less humid, the vegetation fixes the soil less firmly, and the wind becomes the chief sculptor of the landscape. It heaps up the sand during the low-water season, and makes dunes which rise above the level of the greatest floods. These dunes form an unbroken line along the land in the southern part of Entre Rios, in the north of the main arm, with ridges at right angles, advancing toward the south, which rest upon the river clay; like the one which the Ibicuy railway follows across the floodable area. The cattle of the district take refuge on the dunes during floods. During periods of drought, on the other hand, they retain a quantity of water, and this is drawn from surface-wells at their base.

The limits of the zone of the river are clearly marked on the whole of the lower Paraná. It is enclosed on both sides by high barrancas (cliffs), vertical in places where the main current washes their feet, but sloping slightly where there is only a secondary arm with little erosive power. The cliff is broken only at the confluences of small valleys, the flat, filled-up bottoms of which are on the level of the alluvial plain of the Paraná. The cliffs are at their highest in the district of Villa Paraná, where they rise in places to a height of 300 feet. On the right bank the cliffs show a section of the upper layers of the Pampean clays. On the left bank there are æolian clays only at the top of them. Below these are Tertiary marine strata (marls and sandstones with beds of shells). The cliffs of the left bank stretch northwards, with a few breaks, as far as Corrientes, and even into Misiones. Their height gradually diminishes, and the Tertiary marine strata 
are replaced by granitic red sandstone. ${ }^{1}$ On the right bank the height of the cliffs gradually diminishes up river. They are still conspicuous at the confluence of the Carcaraña, but at Santa Fé they rise only about thirty-four feet. North of $3 \mathrm{I}^{\circ} \mathrm{S}$. lat., and for some distance beyond Pilcomayo, the plain of the Chaco is very low, and it is impossible to define exactly the limit of the alluvial zone of the Paraná. The fine clays, grey and white, which form the soil of the Chaco, reach the left bank north of Corrientes, in the esteros of Neembucu. The red sandstone hills of the Asuncion district rise like an archipelago out of this level bed of lacustrine deposits.

There is no obstacle to navigation in the entire stretch from Posadas to the falls of the Guayra on the Parana and the Salto Grande on the Yguassa. Sixteen miles below Posadas the Paraná passes through a series of graduated rapids for about sixty miles ( 1,467 kil. to I,558 kil. from Buenos Aires) wrongly called the Salto de Apipé. The current then rises to a speed of eight knots, and the depth is three feet at low water. These rapids are due to beds of melaphyre, which emerge amongst the granitic sandstone, and the water makes its way between large rocky islands. At Ituzaingo ( $\mathrm{I}, 455$ kil.) the current loses force. There is, however, still a rocky bottom lower down, for ninety miles, at a depth of five feet. Below this the rock only appears on the left bank, and in a few ridges near the bank, or in isolated reefs which it has been easy to mark with buoys.

From Corrientes to $\mathrm{La} \mathrm{Paz}$ the river flows from north to south at the feet of the Corrientes cliffs. These line the main stream between Corrientes and Empedrado, and for thirty-five miles south of Bella-

I In the space between the frontier of Entre Rios and the Rio Empedrado, south of Corrientes, the cliffs expose, above the red sandstone, beds of sand and clay, fluvial alluvia left by former beds of the Parana, the traces of which can be followed from the north-east to the south-west diagonally across the province of Corrientes. 
vista. In the latitude of Riachucho, especially about Bellavista, the cliffs form a series of creeks and capes, in which the west winds create a heavy sea that was dreaded by ships of light draught coming down the river. North of Bellavista, and for more than a hundred miles south of Goya, the main stream is separated from the cliff by a series of alluvial islands ; behind these are lateral arms (riachos) into which pour the rivers of Corrientes. These arms were much used by the early navigators.

Between Esquina and $\mathrm{La} \mathrm{Paz}$ the main bed, which is not in touch with the land on either of its banks, flows in a meandering path for some seven miles, the scale of the bends being double that of the meandering of the Paraguay north of the confluence. The islands are very small, and are strung in a rosary at the top of each bend. The depth is sixty feet at the top of the bend. The shallows are in a line with the islands at the point where the current runs evenly again before the next curve. The depth here is seven, and sometimes even five feet. ${ }^{1}$ These shallows change their places quickly, and it is not always the same bad spot that determines the maximum draught for ships that are to be used in this section. This migration of the shallows is very different from the permanence of the rocky bottom of the stretch between Corrientes and Posadas.

From La Paz to Paraná the main course is outlined by the Entre Rios cliffs. There is no further meandering. The cliffs of hard rock offer far more resistance than the soft alluvia over which the river wanders freely. The permanence of the bed in front of the cliffs leads to a depth of as much as eighty feet. Only here and there a fringe of alluvial stuff separates the

I In point of fact, the ridge is lower at the time of low water, when the current is concentrated in the main channel, so that one always finds one or two feet greater depth there at low water than soundings taken at high water would lead one to expect. 
channel for a time from the cliff. These curves seem, as a rule, to coincide with the confluence of rivers, which bring a heavy load of clay from the tableland; as, does, for instance, the San Feliciano, north of Hernandarias. They are marked by shallows, in strong contrast to the great depths of the straight sections. The San Feliciano paso, which is twelve feet broad to-day, was only six feet broad in Igo8. It appeared on Sullivan's map in $1847 .^{1}$

Below Paraná, as far as the estuary, the careful observations that have been made since I903 on the movement of the river have enabled us to learn some of its laws. ${ }^{2}$ We can distinguish four sections of unequal length. From Paraná to Diamante the river remains in touch with the cliffs of the left bank. It is not straight; it describes a series of linked crescents of equal radius, which seem to be traces of so many meanders. Only one in two of the windings of the cliff is followed by the channel. The wandering of the river is confined within limits as in a fixed mould. The Paracao shallow; which for a long time prevented ships from reaching Santa Fé (gradually deepened by dredging from eight to nineteen feet between I907 and I9II) is at the angle where two of these curves meet. On the right bank the secondary arms continue to follow the river (Paraná viejo, Riacho de Coronda). 3

I A little above its actual position.

- In studying the variations of the bed of the Parana it is necessary to avoid comparing maps drawn at dates separated by long intervals. The differences of such maps are such that they do not enable us to follow the processes by which the actual forms have been derived from earlier forms. The analogies which they show are sometimes due, not to the permanence of the topography, but to the return of a complete cycle of changes, or of conditions analogous to the earlier conditions.

3 The secondary arms of the right bank, north of Santa Fe, were not explored until 1870. Sullivan's map (1847) only mentions the Riacho de San Jeronimo, which is visible for a short distance below $20^{\circ} \mathrm{S}$. lat. The right bank was the domain of the Indians, and the Correntinos would not venture near it. In 1870 ships began to use 


\section{WANDERING OF THE RIVER 249}

Below Diamante the river leaves the cliff on the left bank and slants across the alluvial plain to the clift on the right bank, which it reaches at San Lorenzo. Over the whole of its thirty miles width it resumes the freedom and regularity of features which it had above La Paz. A comparison of the successive maps of the river shows that the scheme of its movements, which one would be tempted to draw up with a regular migration of the islands and loops down river, would not be accurate. The changes of the bed of the river are essentially due to variations in the volume of the different arms, which are constantly changing their size and adapting their shape to the body of water that flows in them. The radius of the curve of each arm is proportional to its volume. A long island is formed between two arms of equal size which both describe symmetrical curves. If the volume of one of them is reduced, its original curve is replaced by sinuosities of smaller radius, and these nibble the edges of the island and give it an irregular shape. If the volume increases again, the winding bed is abandoned and becomes a dead bed, and a larger meander begins. The track followed by the ships then breaks up into a series of meanders over a course of about eight miles and a half, and this means the concentration in a single channel of the greater part of the water of the river, and in narrower bends in the sections where the current is divided between several arms.

From San Lorenzo to San Pedro the river flows by the cliff of the right bank. It is remarkably regular, and has only one slight bend: an exceptionally good site, on which the town of Rosario is built. At almost equal intervals, differing by only about ten to thirteen miles, the river leaves the cliff, and is separated from

the San Javier arm, on which many colonies arose. Further north the Paraná Mini has been used since 1890 for exporting quebracho timber. 
it by an alluvial strand, or by an insular zone a few miles in width. ${ }^{\mathrm{I}}$ Below this bend the current again touches the cliff and landing is easy. The small, older ports of the Paraná-Constitución, San Nicolas, Puerto Obligado and San Pedro-are built on similar sites. It does not seem that the islands at the foot of the cliff tend to extend downward in front of these ports; the points where the river reaches the cliff are fixed. The depth is often considerable at the foot of the cliff (I38 feet opposite Puerto Obligado). The shoals are distributed irregularly at the bends, where the channel moves away from the cliff. They all have to-day a minimum depth of twenty-one feet.2 On the left bank the secondary arms sprawl over the alluvial plain for thirty-five miles north of the river.

The delta begins at San Pedro. The Paraná Guazu, or main arm, leaves the cliff on the right bank and passes to the Uruguayan bank opposite Carmelo. The Paraná de las Palmas, which branches off from it to the south and passes before Campana and Zarate at the foot of the tableland, is deep and easy to navigate, but it is closed at the bottom of the estuary by a six-foot bar, which makes it a sort of blind alley opened only above. The arms of the zone of the delta differ from those of the river-zone proper in the irregularity of their course. Flowing between long islands, they sometimes lie in straight stretches and at other times in meanders or almost perfect buckles. The channels of the southern part of the delta, near Buenos Aires, are called caracoles (snails) on account of their winding shape. The weakness of the current,

x As between $\mathrm{La} \mathrm{Paz}$ and Paraná, it seems possible to show some relation between these alluvial stretches at the foot of the cliff and the confluence of the small valleys of the Pampean plain.

2 The Paso Paraguayo, which has cost the Argentine hydrographic service most work, did not exist at the middle of the nineteenth century. It seems that the channel then kept to the cliff as far as Benavidez, and was continued as far as the source of the Parana Pavon by a very pronounced buckle, of which the Monriel lagoon is a scar. In 1895 the Paso was only fifteen feet deep. 


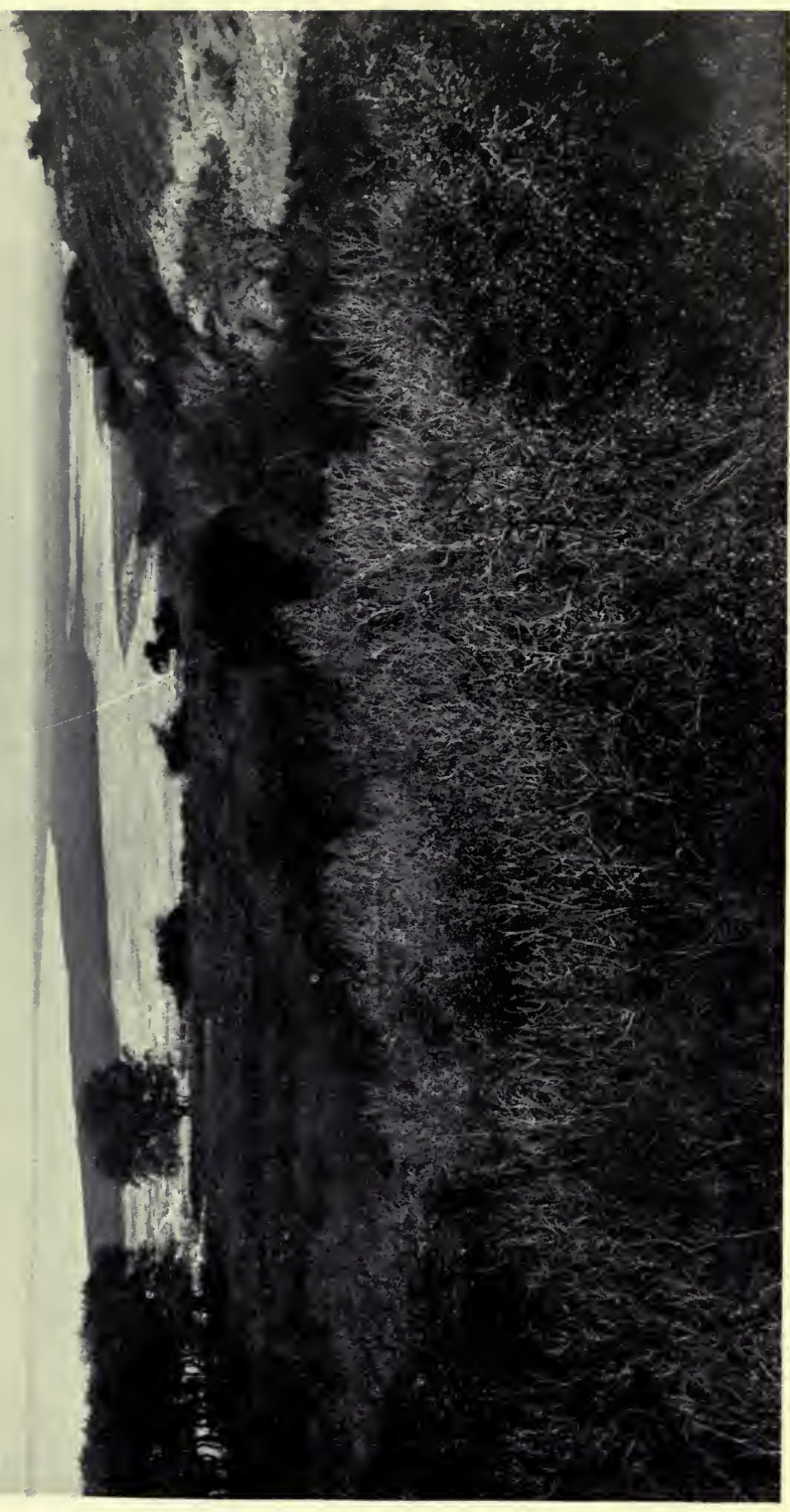

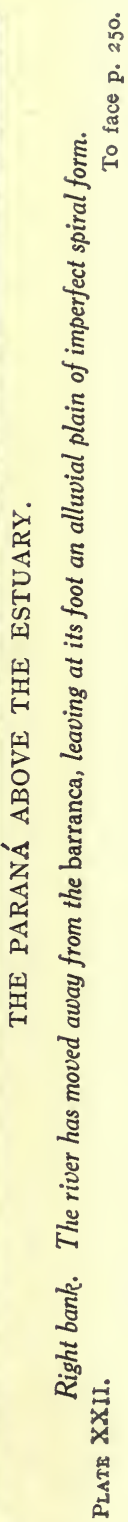





\section{THE ESTUARY}

which is held up by the tide, is seen also in the distribution of the greater depths; they are no longer uniformly found along the concave edge of the bends, but are scattered irregularly. On the Paraná Guazu a depth of 130 feet has been ascertained. Its minimum depth is twenty-two feet.

The study of the estuary may be taken separately from that of the river. It consists of three parts, unequal in size, which open with increasing breadth toward the Atlantic. The upper Rio de la Plata, above Colonia and Punta Lara, has a width of about thirty-five miles. The middle Plata, twice as wide, extends to the latitude of Montevideo and Punta de las Piedras. Then the outer harbour opens between Maldonado and Punta Rasa. The water is still fresh in the middle estuary up to eighty miles below Buenos Aires.

The bottom is alluvial except in the channels between Martin Garcia and Colonia. I Differently from up the river, where the channels have sandy bottoms, while the banks are of fine clay, the channels of the estuary have bottoms of mud and clay. In the outer harbour the pilots recognize the approach of banks by the sand which is brought up by the sounding-lead. The action of the waves, which is not found in the river, accunulates stuff of comparatively large size and weight on the banks.

In spite of the conclusions embodied in the nautical instructions, which describe the estuary as a theatre of rapid changes " occasioned by the continual deposits of sand brought down by the Paraná and the Uruguay," 2 the estuary is, as a matter of fact, in a remarkable state of equilibrium, and there is no trace of a gradual accumulation of alluvia, or of important

The granite which outcrops at Martin Garcia also forms the platform of the English Bank in the outer harbour.

2 The water in the estuary, worked up by waves and tide, contains more sediment than the water of the river. 
changes of channel. The shore of the delta north of the Paraná de las Palmas, covered with rushes which protect it from the attack of the waves, shows neither advance nor retreat. The broad lines of the hydrography of the Rio de la Plata are plainly indicated on Woodbine Parish's map. The English Navy map of I869 (on the basis of observations in I833, I844 and 1856 ) only differs in detail from the present map. The stability of the channels is surprisingly different from the changes in the bed of the river in the floodzone. The permanence of the bottom, in spite of the loose deposits of the estuary, is explained by the regularity of the currents. These currents, which determine the submarine topography of the Rio de la Plata and the distribution of the banks, are not of river origin. They are tidal currents.

There are two groups of shoals in the estuary. The first, the Playa Honda, occupies the whole western part of it up to a line drawn from Buenos Aires to Colonia. These banks leave a narrow passage in the north, opposite the Uruguayan shore, and this is followed by ships going to Uruguay and the Paraná Guazu. The second group of shoals is the Ortiz Bank, triangular in shape, which rests in the north on the Uruguay coast below Colonia, while its point extends south-eastward to eighteen miles north of the Puntá de las Piedras. It keeps the zone of deepest water in the middle estuary to the south, near the Argentine shore. In the latitude of the point of the Ortiz Bank, on a line from Montevideo to Puntá de las Piedras, the middle estuary is separated from the outer harbour by a bar (barra del Indio) with thirty-eight feet of water, caused by the transverse currents which circulate from point to point inside the English Bank.

The tide in the estuary is very irregular. The southeast winds increase the flow and retard the ebb. When they are blowing, it often happens that the level of the water in the upper estuary keeps up from one 
tide to the next, sometimes for several days. The tide, which is slight at Montevideo, is greater at the bottom of the harbour on the Barra del Indio, sometimes rising nearly forty inches there. From there it advances with difficulty northward, over the Ortiz Bank, along the Uruguayan shore, whereas it passes freely into the deeper zone on the Argentine side. ${ }^{x}$ At Buenos Aires it still has a depth of thirty inches. From there it advances northward by the Martin Garcia channels beyond the Playa Honda. The channel of the Pozos del Barca Grande, which crosses the Playa Honda bank from north to south, parallel to the edge of the delta, is oriented in conformity with the tidal currents and maintained by them. It is not attached to the river, and it is separated from the mouths of the Paraná de las Palmas or the Paraná Mini by shallows which are navigable only to small boats. The Rias of the Uruguay, where the tide raises the water twelve inches, forms a sort of reservoir which, at the ebb, feeds a strong current round Martin Garcia and sweeps the channels there.

The work done for the improvement of the estuary includes the deepening to thirty feet of the Barra del Indio and the dredging of a straight channel from that point to Buenos Aires. Steamers of large tonnage going up the Paraná leave this channel twentysix miles east of Buenos Aires, and turn north in order to pass east of Martin Garcia, and enter the river by the Paraná Guazu or the Paraná Bravo. Since IgoI the Argentine Government has considered a plan of opening a direct route from Buenos Aires to the Paraná de las Palmas, either by cutting an artificial canal at the foot of the cliffs, across the Tigre archipelago, or by using the channel of the Pozos del Barca Grande and cutting the narrow bar which closes the Paraná de las Palmas below. If

I The current at high tide is stronger than at low tide, and it has shifted to the north-east the streams which find an outlet on this side. 
this were done, the ports of the Paraná de las Palmas would have direct access to the sea. Moreover, the new route from the Parana to the Atlantic would be entirely within Argentine territory, out of range of the Uruguayan shore, and Buenos Aires would become a necessary port of call both on departure and return.

Above the estuary, the work for the improvement of the Paraná began in 1904 and I905. Since I9ro the material dredged from the bed of the river has risen to $3,500,000$ cubic metres a year on the average. The experience gained in the course of this work has enabled the Argentine hydrographic service to adjust its methods to the incomparable force of the river. It is impossible to maintain a general rectification of the bed and the banks, as is possible with European rivers. The only thing to do is to submit quietly to the plan which the river sketches for itself, and be content to deepen the difficult passages on the line of the main arm. Suction dredges, which work easily in the sand, attack each ridge or paso from below, making a channel into which the waters flow, so that it tends to enlarge itself up stream. The dredges are shifted from bank to bank according as the soundings tell of the formation of fresh obstacles to navigation. They were at first concentrated below Rosario, where the Argentine Government had to carry out certain engagements contracted with the Port Company; then they were scattered as far up as Santa Fé. The actual equipment suffices to carry out the programme that had been drawn up-to maintain a depth of twenty-one feet as far as Rosario and of nineteen feet as far as Santa Fé.

As regards the section above Santa Fé, the engineer Repossini advises that, instead of adopting a programme of expensive dredging with uncertain results, they should first think of adjusting navigation to the natural conditions, and they are such as would be considered very favourable in Europe. The hydro- 


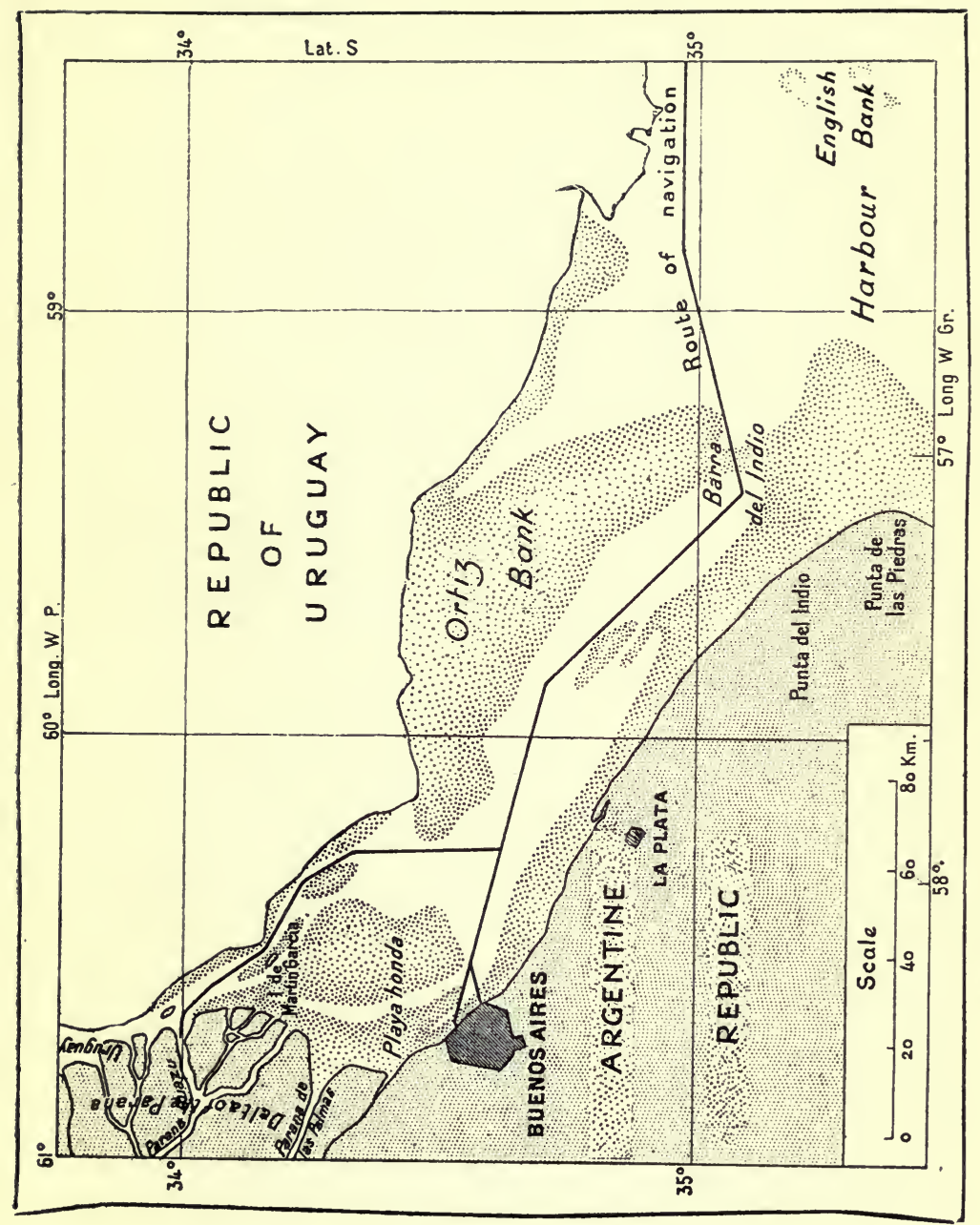

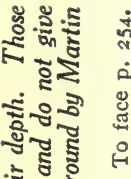

$\div 8$

ปे की

훙요

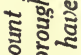

पुํ워 के

स

嵌

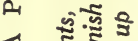

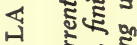

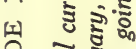

- 귫

मี 표 के

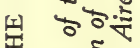

ज ธू๊

(1) ปัँป๊

म

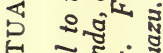

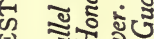

(되 진.

కิ

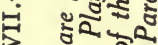

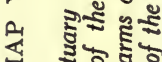

近 矛次文

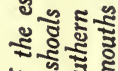

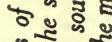

ज्ञ

हू้

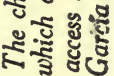



graphic service would, however, still have two functions: in the first place, the topographical study of the river and the constant placing of buoys, and, in the second place, the observation of its behaviour and anticipation of variations of level. The utility of the work of foreseeing floods, which has been carried on since 1907, has been abundantly proved. It published a daily bulletin of forecasts, based upon observation of the pluviometric scales of the upper river, which is equally valuable to the navigators and to breeders in the floodable area. It enables the breeders to get their cattle into safety before the floods come. On the other hand, the ship can, thanks to the bulletin, foretell what depth of water it will find at critical passages, and calculate exactly the load it can carry, and so complete its cargo lower down. The service of forecast of floods has morally improved navigation on the Paraná by suppressing every possible pretext for wilful stranding, which had become a current form of speculation.

Nothing is more varied than the fleet which now serves the Paraná. It includes tramps, and long, slim European ships, which load up with cereals and meat; large river boats, luxurious and light; barges and tugs, lighters and schooners, which have compensation for their slowness in their cheapness.

As regards navigation, the river is now divided into three sections. Maritime navigation ascends as far as Santa Fé. At Rosario and Santa Fé it goes right to the heart of the zone of cereals and to the fringe of the forest area. The upper section, between Rosario and Santa Fé, is less safe than the lower section, and this is reflected in the cost of freightage from Santa Fé.

The ports of the lower Paraná, between Santa Fé and Buenos Aires, may be classed in three categories. The ports of the first group are built on low land 
that is liable to be flooded. Every year the floods threaten their traffic. That is the character of Colastiné, east of Santa Fé, which specializes in shipping quebracho timber, or Ibicuy, on the Paraná Pavon, in the south of the province of Entre Rios, which, however, is protected by excellent works. The small ports of the barranca of the southern bank, on the main river and on the Paraná de las Palmas, form a second group. They ship meat (Campana and Zarate) and cereals (San Nicolas and Villa Constitución), and they are admirably adapted for this by their natural situation. Steamers come right up to the cliff without any need of special works on the shore. The sacks of wheat are let into the ships down sloping gangways from stores excavated in the cliff or from wagons. None of these ports are equipped for receiving imports. The third group comprises ports with complete apparatus for both export and import. The chief of these is Rosario. It was the increase of imports between I850 and I860 that stimulated its early progress. To-day the tonnage of the goods unloaded at Rosario is nearly one-half the tonnage of the cereals shipped there. Yet, in spite of appearances, it is the imports that account mainly for the busy life of its quays. The port company does the unloading itself, as well as the handling and storing of the goods imported, but it is content to receive dues on all exports within the area for which it has a monopoly. Only a small part of the cereals exported uses its elevators. A deep-water port, equipped like that at Rosario for import and export, has just been constructed at Santa Fé. Already it competes with Colastiné for the export of quebracho. Its import trade is still small, as such trade requires large capital and a whole network of relations with the adjoining country, and that is not the work of a day.

The second section of the river stretches from Santa Fé to Corrientes, and is continued up the Paraguay. 
The transport of quebracho timber and tannic acid is the chief item of its trade. The maximum draught of the vessels it admits at normal low water is six feet. Some of the ports on the left bank (Esquina, Goya) and all the ports on the right bank (Reconquista, Barranqueras, etc.) are at some distance from the main bed, or lateral arms. The Chaco works have generally a flotilla of steamers and barges. It is the exporters of timber and extract of quebracho to Europe who most strongly demand the deepening of the bed of the Paraná above Santa Fé. Sailing ships share with the river steamers the transport of the products of the Paraguay and of Corrientes (hides, tobacco and matê). The transport of oranges alone from San Antonio, Villeta, Pilar and Humaïta represents an item of tens of thousands of tons.

The third section of the river stretches from Corrientes to Posadas, and beyond. Sailing ships have disappeared from this section, as they cannot make the Apipé rapids. Steamers of four and a-half feet draught and $5_{50}$ tons are now used on it, but they cannot proceed at low water. They provide a direct service between Buenos Aires and Posadas, though the service is not very economical, because it does not permit them to use to the full the transport-capacity of the river below Corrientes. Most of the goods for Posadas are, therefore, trans-shipped at Ituzaingo, below the rapids, or at Corrientes. The steamboat companies which serve Posadas are obliged, in order to secure the economical transport of goods shipped on the upper Paraná, to maintain lines which go up the Paraguay as far as Asunción, and take on at Corrientes the goods that come from Posadas. Higher up, the falls of the Guayra and the Yguassu set an impassable limit to the enterprise of Argentine vessels. Boats on the stretch above Yguassu on the Parana feed the railways of the Brazilian tableland. The traffic of the upper Paraná consists chiefly of maté from Misiones 
and cedar-planks from the Posadas saw-mills. Rafts of timber are stopped at Posadas and rarely follow the river further.

The Argentine statistics of navigation are obscure. They confuse under one heading the river-traffic between Posadas and Brazilian territory, or between Corrientes and the Paraguay, and the exports of the Pampean region to Europe. It is difficult to get from them an idea of the real traffic, or to distinguish the tonnage loaded or unloaded at each port from that which merely touches its quays in ships going up or coming down the river. They credit a score of ports with a total tonnage of (entries and clearances together) more than 500,000 tons.

At all events, they do enable us to distinguish between ports exclusively devoted to river traffic and those with direct relations to oversea ports. Nearly all the boats destined for the Paraná touch at Buenos Aires, which remains the chief importing centre, on the way up, and unload there. They then go empty to Rosario, San Nicolas, or Santa Fé to take on a full cargo of cereals or timber, and set out down the Paraná for Europe without calling at Buenos Aires. Clearances for interior navigation at the port of Buenos Aires are far more numerous than entries. From IgI2 to I9I4 Buenos Aires received on the average, coming from interior ports, $I, 750,000$ tons, of which $I, 635,000$ were cargo. It cleared for the same ports ships totalling $3,275,000$ tons, of which $1,580,000$ were in ballast. The latter figure fairly represents the tonnage of seagoing ships sent up river empty after discharging on the quays of Buenos Aires. At Rosario, San Nicolas and San Pedro, on the other hand, the tonnage of clearances for Argentine ports is much less than the tonnage of entries. I The total movement of goods at

$\times$ Movement of internal navigation at Rosario (average I9I2-1914) : entries, I, I08,000 tons, of which 690,000 in ballast; clearances, 580,000 tons. At San Nicolas: entries, 400,000 tons, of which 
the port of Rosario is 410,000 tons entries and 375,000 tons clearances for interior navigation, and $I, 100,000$ tons entries and I,824,000 tons clearances for navigation abroad.

According to Repossini's calculations the tonnage of exports on the lower Paraná south of Santa Fé rose in I9Io to $4,000,000$ or $4,500,000$. The imports, almost entirely confined to Rosario, were about a fourth of this figure. For the middle and upper Paraná, Repossini estimated the volume of the traffic at 800,000 tons, of which quebracho was two-fifths.

The navigation of the Parana is one of the chief sources of the prosperity of Buenos Aires. Even if the development of the import trade at Rosario or Santa Fé is partly at the expense of the capital, and the boats laden with cereals do not stop at its quays, still the coasting traffic on the river is in great part meant for Buenos Aires. In returning, rather than go empty, the boats take cargoes of European products bought from the Buenos Aires importers. By means of the Parana the import-trade sphere of influence of Buenos Aires reaches beyond the frontiers of Argentina, as far as Paraguay and part of Brazil. Buenos Aires is, moreover, the main centre for equipping the steamboats of the river. Its capital dominates the Paraná. Lastly, the Parana supplies it with an export freight which must not be overlooked. It is at Buenos Aires that the hides, tobacco and timber and extracts of quebracho for oversea markets, shipped on schooners in the upper reaches of the river which are impassable for steamers, are trans-shipped for abroad.

440,000 in ballast; clearances, 4,000 tons. The difference between the entries and the clearances represents ships starting straight for Europe. 


\section{CHAPTER IX}

\section{THE POPULATION}

The distribution of the population-The streams of emigration to the interior-Seasonal migrations-The historic towns-The towns of the Pampean region-Buenos Aires.

A LARGE-SCALE chart of the mean density of the population for each province-like those which were published in the latest Argentine Census-reportshas no geographical value for the west and northwest, where oases of slight extent are separated by vast desolate stretches, deserted because of the lack of water. In the Pampean region, on the other hand, the population is distributed in a very regular manner, and the mean densities calculated fairly represent the facts.

To the several types of exploitation, of which we have studied the distribution on the Pampa, there correspond unequal densities of population. Cattlebreeding, for instance, requires only a thin population. The early pastoral colonization of the plain on the west of the Salado was carried out, between I88o and I890, with a very small number of workers. A large ranch of 400 square kilometres on the northern edge of the Pampa (the Tostado ranch) only employs about a hundred men, or one for four square kilometres. The density increases appreciably for sheepbreeding on the pastos tiernos of Buenos Aires province, where a ranch of a hundred square kilometres, devoted to producing wool, with fifty or sixty shep-

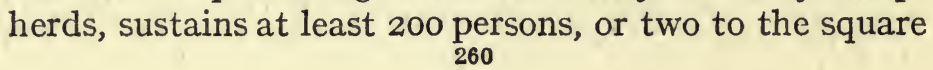


kilometre. ${ }^{I}$ The density is not appreciably greater in the area of wheat-growing on a large scale, where the extent cultivated by one family reaches, including fallow, 200 hectares. But it may, even apart from the urban population, be more than ten to the square kilometre in the maize belt.

The growth of the population of Argentina can be followed closely from the middle of the eighteenth century. A Census taken in I774 gives the Buenos Aires district within the first line of forts 6,000 inhabitants. At the end of the eighteenth century (Census of I797, quoted by D'Azara) the population of the province of Buenos Aires, without the town, was a little over 30,000 souls, the zone occupied having been extended in the meantime, at least in part, as far as the Salado. Woodbine Parish estimates the population at 80,000 in 1824 , at the time when the expansion southward, beyond the Salado, as far as the Sierra de Tandil, began. It doubled between I824 and 1855. The northern departments then counted 45,000 inhabitants, the western 58,000 and the southern 63,000 . The density was still a little greater in the north, along the road to Peru, but the advance of sheep-rearing in the south was beginning to change the centre of gravity of colonization. The first regular Census of the Argentine Republic in I869 showed a still more rapid advance. The population of the Buenos Aires province had grown to 315,000 inhabitants. The increase was greatest in the west, where tillage began to extend round Chivilcoy, beyond the pastoral area, and in the south, where sheep-farms multiplied. The population of the southern departments more than doubled in fourteen years ( 137,000 inhabitants to 70,000 square kilometres in occupation, or two to the square kilometre).

However, the Pampean region-Buenos Aires (includ-

I The density is twenty times less in the ranches which use the meagre pastures of the Rio Negro. 
ing the capital), Santa Fé, and the southern part of Córdoba-still had a smaller population than that of the northern and north-western provinces: 626,000 as compared with 813,000 . The Mesopotamian provinces had then 263,000 inhabitants.

The proportion was reversed twenty-five years later at the 1895 Census. The population of the Pampas had increased threefold, and was more than a half of the entire population of the country. That of the western and north-western provinces was about a third of the whole, and had only increased by fifty per cent.

If one considers in detail the distribution of the population of the Pampean plain in I895, one sees that beyond the suburbs of Buenos Aires the area of greatest density - five to eight per square kilometrewas in the north-west, between San Andres de Giles and Pergamino, a district of advanced methods, where the cultivation of maize was beginning to occupy a good part of the land. The population was confined to the west of the preceding zone, in the agricultural area of Junin, Chacabuco and Chivilcoy. This area, where maize and wheat were next each other, already embraced Viente Cinco de Mayo (five to the square kilometre) on the west and Nueve de Julio $(2 \cdot 5)$. In the south of Buenos Aires, the departments of the left bank of the Salado, which were entirely given up to breeding, but long colonized, had a density of three to five per square kilometre. The region lying between the lower Salado and the Sierra de Tandil, a sheep-breeding area, then giving good returns but of recent colonization, had not more than three. The density falls rapidly as one goes westward. It sinks to less than one in the northwest and west of the Buenos Aires province, in the area where the cattle-breeders from the east had settled. At Santa Fé, the region of the colonies, at the level both of Rosario and Santa Fé, had five inhabitants per square kilometre. But beyond the Córdoba 


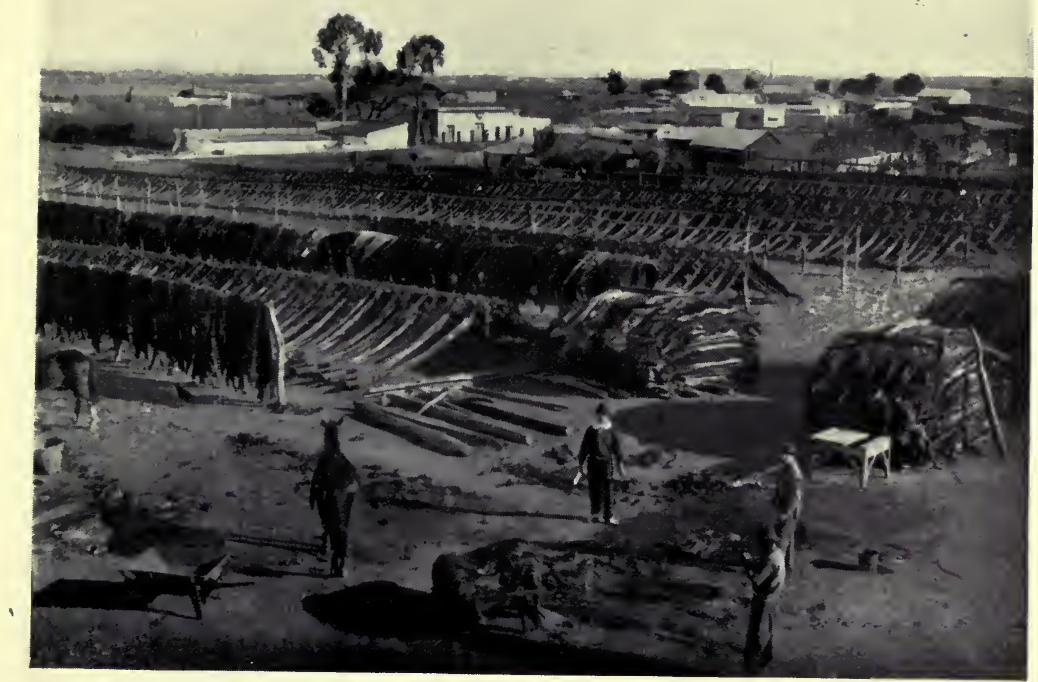

THE OLDER INDUSTRIES OF THE PAMPA: DRYING HIDES.

Photograph by Soc. Fotografica de Aficionados.

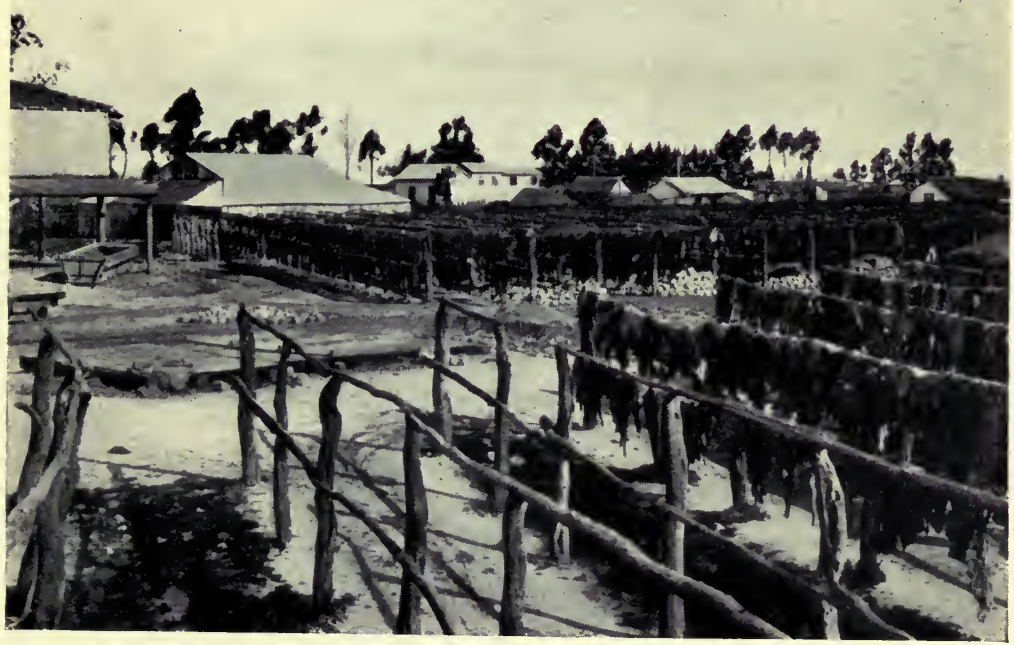

DRYING SALT MEAT.

Photograph by Soc. Fotografica de Aficionados. To face p. 262 . 

frontier the density falls to two in the San Justo department, and still less further south, at Marcos Juarez, Union and General Lopez.

In I9I4 the density was more than fifteen in the whole of the maize area in the Buenos Aires and Santa Fé provinces, and it approached this figure in the departments of the old agricultural colonies on the middle Salado. In the region of the lucerne farms it was three to five, except in the south-east (departments of Veinte Cinco de Mayo, Nueve de Julio and Bolivia), where it rose, thanks to the co-existence of ranches and of wheat and maize. It sank to between two and three in the wheat area in the south and southeast of Buenos Aires. At Santa Fé the district of the colonies had seven to the square kilometre.

The growth of the population is partly explained by immigration from Europe. Foreigners were, in I9I4, 30 per cent. of the total population. ${ }^{\text {I The }}$ proportion of foreigners to the total population is one of the indications by which we can best follow the advance of colonization. As soon as it relaxes in any region, the number of immigrants diminishes. (The children born of foreign colonists in Argentina are considered indigenous in Argentine statistics.) In I869 the proportion of foreigners rose to 4I7 per I,000 in the province of Buenos Aires (without the capital). This was the great period of pastoral colonization and the development of sheep-breeding. It was then only 156 per I,000 at Santa Fé. In I895 the proportion of foreigners sank to 309 per $\mathrm{I}, 000$ at Buenos Aires, but rose to $4 \mathrm{I} 9$ at Santa Fé, where the date almost marks the end of the great period of agricultural colonization. In I9I4 the proportion of foreigners at Buenos Aires rose to 340 per I,000 (development of the maize region and the southern

- All Europeans, except a few tens of thousands of Bolivians in the Salta and Jujuy provinces, a few thousand Brazilians in Misiones, and a few thousand Chileans at Neuquen. 
wheat area). It sank at Santa Fé (350 per I,000), in spite of considerable immigration in the southern maize-growing departments. At the same time there was a great influx of foreign population in the province of Córdoba (200 per I,000) and in the area of the Central Pampa ( 360 per I,00o). I

The recent enumerations also enable us to follow the displacements of the indigenous population on Argentine territory and the part this has had in colonization. Outside the Pampean region the parts of the country which have proved centres of attraction for the Argentine population are the sugar provinces of Tucumán and Jujuy and the province of Mendoza. In I895 Tucumán had 40,000 inhabitants who had been born in other provinces, Jujuy $I_{5,000}$ and Mendoza 19,000. The attraction of Tucumán was mainly felt in the adjoining province of Santiago (I2,000 immigrants) and Catamarca (I2,000). At Mendoza the immigrants came mainly from San Juan $(7,000)$ and San Luis $(3,000)$. The attraction of the timber region is more difficult to estimate, because most of the obrajes are in the province of Santiago, which found the workers itself, and the enumerations have not taken into account displacements within each province. Nevertheless, immigration into the land of the quebracho Chaqueño, along the Paraná, can be recognised from I895 onward. It was maintained by the Corrientes province. Santa Fé has I0,000 immigrants from Corrientes, of whom 6,500 are in the forestry departments of Reconquista and Vera. The Chaco region maintains 2,000 Corrientes wood-cutters and several hundred from Santiago

I I have referred elsewhere to the magnitude of the stream of European immigration at Mendoza. In Patagonia (territory of the Rio Negro, the Neuquen, the Chubut, the Santa Cruz, and Tierra del Fuego, of which the total population is only 104,000) sheep-breeding has attracted a considerable number of immigrants ( 428 foreigners per 1000 in 1914). 
and Salta. Corrientes has also sent 5,000 emigrants to Misiones.

In the Pampean region the population of Buenos Aires in I895 included very few who came from other provinces. The population of Santa Fé was more mixed. The attraction of the agricultural colonies had brought 65,000 Argentine immigrants. They came mainly from the left bank of the Paraná and Córdoba. The immigrants from Córdoba are localized along the railway from Rosario to Córdoba, in the Belgrano and Iriondo departments and the town of Rosario. The migration of the Santa Fé colonists to the new lands in the west had scarcely begun at that time. They were still only 3,000 in the Buenos Aires province, and 5,000 at Córdoba; most of them were in departments adjacent to the old colony area. The colonization of Córdoba began simultaneously in the east, toward Santa Fé, and in the south-west, in the Rio Cuarto department, to which the breeders from San Luis went. Similarly, the Argentine population of the Central Pampa includes elements from the east as well as European colonists and elements from the north-west (10,000 immigrants from the Buenos Aires province, 3,000 from San Luis).

The I9I4 Census has less complete details in regard to interior immigration than its predecessor. The migrations had not ceased. The attraction of Tucumán and Mendoza had, in fact, decreased. The province of Tucumán had 55,000 Argentine immigrants, the province of Jujuy 15,000 , the province of Mendoza 34,000. The provinces of Mendoza and Corrientes remained nuclei of considerable immigration (38,000 and 63,000 immigrants). At Santa Fé the number of emigrants who left the province to settle at Córdoba and in the remainder of the Pampean region rose from 14,000 to 87,000 . The Patagonian territory also had a large excess of immigrants from other provinces. 
Periodic migrations with no definitive change of residence are not given in the official statistics. The importance of these migrations in northern Argentina has been noted in the chapters we devoted to Tucuman and the forestry industry. They occur also in the Pampean region, where they are due chiefly to he need of labour for the harvest and the threshing of wheat and flax, and for reaping the maize. Miatello has given us a detailed analysis of the phenomenon for the province of Santa Fé in I904. The period when the wheat and flax growers need help is from November to February. It begins in March for the maize farmers, and lasts so much longer when the harvest is good. The temporary immigrants come partly from Europe. Not only is the stream of immigration to Argentina fuller during the months which precede the harvests, while the stream of re-emigration to Europe is greatest in the autumn, but it is not a rare thing for Italians to go every year to Argentina merely to stay there during the harvest, when wages are high. This seasonal immigration from Italy is of long standing; it is mentioned by Daireaux in 1889 . These foreigners, however, are only part of the adventurous crowd enlisted for the harvests on the Pampean plain. Seasonal migration is everywhere a national practice. The labour employed in reaping the maize includes elements borrowed from the towns near the maize belt. But all the provinces round the Pampean region send their contingent of temporary immigrants. Some even come from the valley of the Rio Negro at Bahía Blanca, from San Luis, and even from Mendoza to the Central Pampa and the Córdoba province.

The oldest, and still the largest, stream is that which comes from the Santiago province. D'Orbigny notices in 1827 the temporary streaming of Santiagueños to the coast. In that year slow progress was made with the wheat-harvest of Buenos Aires 
because of the shortage of labour. "The forced levies for the army prevented the Santiagueños from going to hire themselves, as was their custom, in fear lest they should be compelled to serve." r

Temporary emigration began, no doubt, with the journeys which brought the northerners to Buenos Aires as drivers of convoys of wagons. Santiagueños were numerous amongst these troperos. Lorenzo Fazio collected reminiscences of these journeys in the land of the bañados. ${ }^{2}$ They go back to the first quarter of the nineteenth century, the period before the diversion of the Rio Dulce and the ruin of Salavina and Atamisqui. "My father," said one of his informants, "drove wagons of wheat to Córdoba, and sometimes to Buenos Aires, where he sold them and bought goods-stuffs in exchange. $\mathrm{He}$ bought the wheat at Loreto, Atamisqui or Salavina. It was a year before he got back, because it was necessary to wait for the rain and the growth of the vegetation, otherwise his animals would have died of thirst or hunger on the road." The journeys of the troperos meant a long spell of idleness in the Pampean region, precisely at the harvest season. Naturally, they would lend a hand in it.

The temporary emigration of the Santiagueños continued throughout the nineteenth century. It was maintained even during the disturbances under the government of Rosas, which almost entirely put an end to commercial relations between Buenos Aires and the northern provinces. When Galvez passed through the villages on the Rio Dulce he noticed that there were few men in them. They had scattered over the roads or were, as he says, andariegos. Only the women remained. The province of Buenos Aires received the Santiagueños in crowds, offering their

D'Orbigny, Voyage dans l'Amerique méridionale, vol. i. p. 528.

2 Lorenzo Fazio, Memoria descriptiva de la provincia de Santiago del Estero (Buenos Aires, 1889). 
services. Chivilcoy and the whole region of the chacras of maize and wheat received their caravans for the harvest, and some were kept for the sowing. Even the ranchers took advantage of this reinforcement, and hired the men for marking. In the autumn they went back with their tropillas, much dreaded by the breeders whose land they crossed, stealing any horses that were not well guarded.

The province of Santa Fé, especially in the agricultural departments of the north-west, is now the chief theatre in the Pampean region for the immigration of the Santiagueños. It does not always come by rail, but has to some extent preserved its primitive and picturesque features. The immigrants arrive in troops on mules and horses, and scatter in November over the colonies.

The population of Argentina has also felt the attraction of the urban centres. The growth of the towns is due to both foreign and national immigration. The development of urban life, which is one of the characteristic features of modern Argentina, is a recent phenomenon. There was no indication of its coming in the eighteenth century. D'Azara was, on the contrary, struck by the absence of communal life (pueblos unidos). The scattering of the population was a result of the predominance of breeding. "If these people found profit in agriculture, one would see them gather together in villages, instead of the whole population being dispersed in ranches." I It is this scattering of the population rather than an absolute numerical inferiority-the solitude, "the desert, the universal horizon that forced itself into the very entrails of the land " 2-that moulded the fiery soul of the gaucho.

The primitive urban sites were all either on the

I F. de Azara, Memorias sobre el estado rural del rio de la Plata en I80I, p. Io.

- Sarmiento, El Facundo, p. I9. 


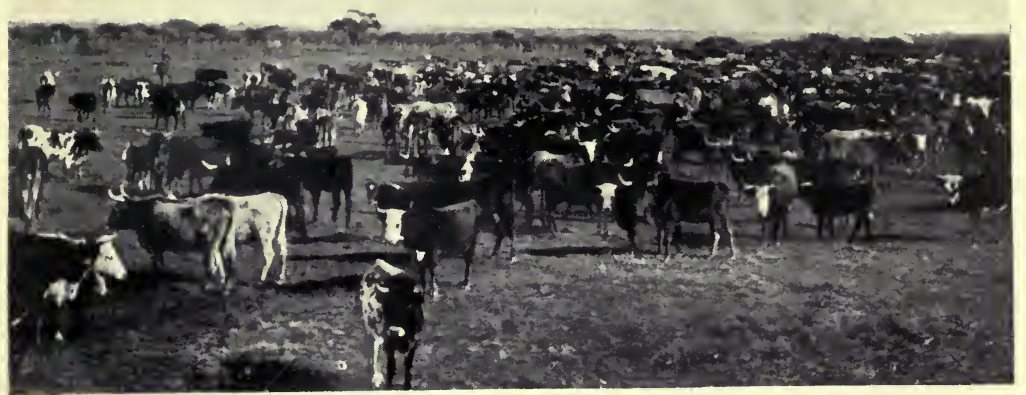

A HERD OF CREOLE CATTLE.

Photograph by Widmayer.

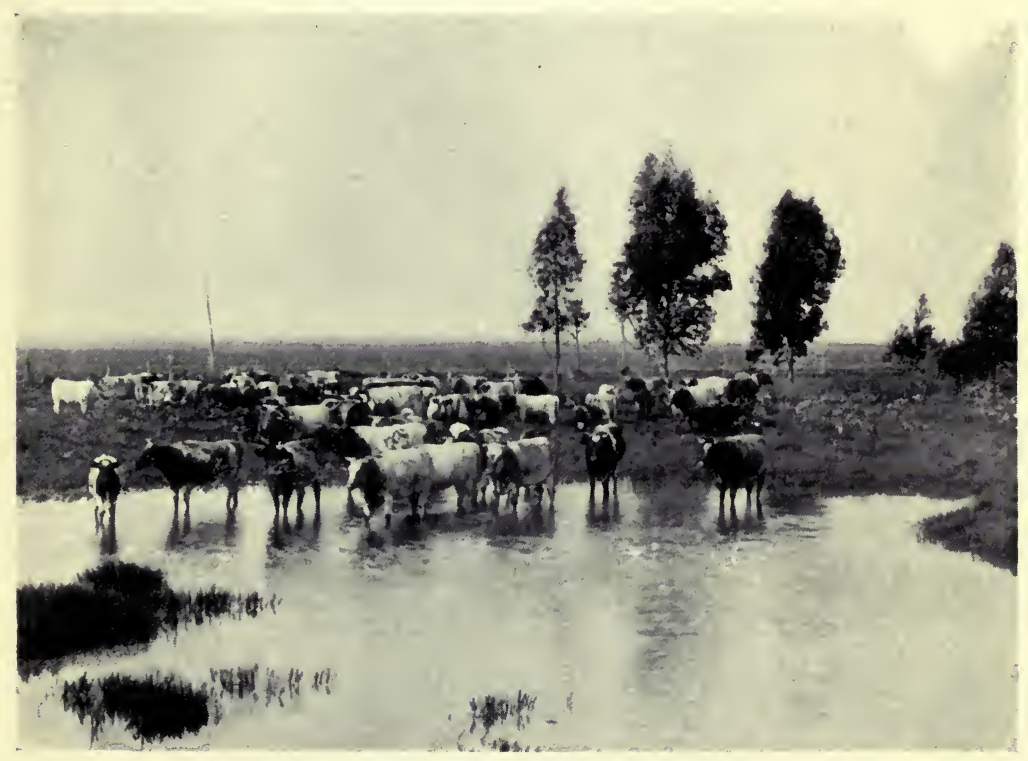

A HERD OF DURHAM CATTLE.

Photograph by Soc. Fotografica de Aficionados. To face p. 268. 

river or on the historic roads to Chile and Peru. The only towns of the Parana region at the end of the eighteenth century were Buenos Aires, Santa Fé and Corrientes. As to towns in the interior, Helms's journey in 1778 gives us some idea of their size. Córdoba, at the crossing of the Peru road and the tracks to the province of La Rioja, had then I,500 white inhabitants and 4,000 blacks. As it was near the Sierra, which provided granite and lime, it had some semblance of architecture, and had paved streets, which struck even the traveller from Buenos Aires. The attraction of its schools was felt over a wide area. We still have a list of students from Paraguay who studied at Cordoba University in the eighteenth century. ${ }^{\mathbf{x}}$ Tucumán and Salta, especially Salta, also were busy centres. Salta had 600 Spanish families and 9,000 inhabitants in all, and its influence extended as far as Peru and Chile. Jujuy, on the other hand, was a very small town. Helms mentions the decay of Santiago del Estero. The trade which had once flourisned there had, he says, gone in a different direction. The prosperity of Santiago was, as a matter of fact, connected with traffic on the direct route from Santa Fé to Tucumán, which ceased at the close of the eighteenth century. Santa. Fé also was a decaying town at the close of the eighteenth century, and would remain such until the middle of the nineteenth. Its distress was due, not merely to the suspension of its direct trade with Peru, but also to the decay and isolation of Paraguay, which had provided most of its trade and for which it acted as intermediary with the Andean provinces.

The great development of urban life in Argentina dates from the time of the colonization of the Pampean region. The ratio of the urban population has risen considerably during the last twenty-five years. In 1895, II3 centres with more than 2,000 inhabitants

sublished by the Revista del Instituto Paraguayo (vol. iv. p. 334). 
comprised 37 per cent. of the total population of Argentina; in I9I4 the number of urban centres was 322 , and they comprised 53 per cent. of the population. The population of towns with 5,000 to 20,000 inhabitants has increased threefold in twenty years, rising from 312,000 in 1895 to 977,000 in I9I4. Large new towns like Rosario and Bahía Blanca were created. The relative sizes of the older towns changed rapidly. Tucumán and Mendoza (I2I,000 and 92,000 inhabitants) shot beyond Santiago and Salta $(22,000$ and 28,000 inhabitants). The towns of the northwest, Catamarca and Rioja, are, on the other hand, scarcely developed.

When one examines a chart of the urban population of the Pampean region, one finds that colonization has led to the creation in it of ten chief centres, of from 15,000 to 25,000 inhabitants, and some fifty secondary centres, of from 5,000 to 12,000 inhabitants, which all have a distinctly urban character. This association of urban centres and a scattered agricultural or pastoral population is one of the original features of the way in which the Pampa was peopled. There is no village, or purely rural group. The distribution of these centres on the plain is fairly regular. They are a little closer together in the districts near the Paraná, to the north of Buenos Aires, where the population is older, and where the density, even of the rural population, is at its highest. The territory of the Pampa is divided between the spheres of influence of these various centres. Their radius is as low as ten miles in the north-west, and is about twenty miles in the south of Buenos Aires and twentyfive in the extreme west.

A secondary railway nucleus has generally settled the sites of them (San Francisco-Pergamino, Junin). Their population comprises all the workers needed for the flow of the economic life of the Pampa: agents for the exporters of cereals, merchants who supply the 
colonies with imported goods-especially agricultural machinery-bankers and insurance companies, surveyors and lawyers. Those which have the best service of trains have a certain amount of industrymills and breweries-the products of which are absorbed locally. These towns derive all the elements of their life from the Pampean region itself, and have no direct relations either with foreign markets or with other parts of Argentina. ${ }^{x}$

But the towns of the Pampa which have grown most rapidly are the ports. Rosario rose from 23,000 inhabitants in I869 to $9 I, 000$ in I895 and to 245,000 in I9I4; Bahía Blanca from 9,000 in I895 to 62,000 in I9I4. The actual population of the Pampa ports is not at all in proportion to the part which each plays in the export of Pampean products :-

\section{Export of Cereals in thousands of tons.}

(Average for 1913-19I5)

$\begin{array}{cccccc}\text { Rosario. } & \text { Buenos Aires. } & \text { Bahía Blanca. } & \text { San Nicolas. } & \text { La Plata. } & \text { Santa Fé. } \\ 2,7 \text { I } 6 & 2,051 & \text { I,075 } & 65 \text { I } & 459 & 278\end{array}$

Population in 1914 .

$245,000 \quad 1,575,000 \quad 62,000 \quad 19,000 \quad 137,000 \quad 64,000$

Some centres, such as Campana, Zarate, San Pedro or San Nicolas, which load up meat or grain in great quantities, have nevertheless remained small towns. Neither the trade in meat nor that in cereals is enough of itself to sustain a busy urban life. In point of fact, the growth of the Pampa ports is mainly connected with their function as importing ports and markets of capital. The close dependence of Bahía

- Only two of them, Villa Mercedes and Villa Maria, are on the edge of the Pampa. We have seen elsewhere the part which the extensive breeding of the north-west plays in the business of the Villa Mercedes cattle-market. Villa Maria also derives some advantage from its nearness to the scrub. Its limekilns receive limestone from the Sierra de Cordoba, but they get their fuel locally, from the men who clear the scrub. 
Blanca upon Buenos Aires in both these respects seems to forbid it all hope of ever becoming the equal of Rosario. The prosperity of Rosario was founded during the time when Buenos Aires was isolated, between 1853 and 1860 ; this enabled them to organize an import trade there and to accumulate a nucleus of independent capital. ${ }^{x}$

The development of Buenos Aires must be studied separately. It does not merely reflect the success of the colonization of the Pampa; it is a phenomenon of a national order. The attraction of Buenos Aires has been felt throughout the whole land. In I895, of a total population of Argentine birth of 318,000 souls, more than a half-I67,000-were born in the provinces. ${ }^{2}$ The way in which the prosperity of Buenos Aires is bound up, not only with that of the adjacent territory but with that of the whole country, is seen in the stability of the figure representing the number of the inhabitants who have come from foreign lands. While the proportion of foreigners in each of the provinces varies from one census to another, according to the displacements of the stream of colonization, it remains almost the same at Buenos Aires: 496 per $I, 000$ in 1869,520 in 1895,493 in IgI4.

The population of the city of Buenos Aires was estimated by Helms in I788 to be between 24,000 and 30,000. D'Azara put it at 40,000 in I799. The Revolution did not interrupt its growth. According to the estimate of Woodbine Parish the city had 8I,000 inhabitants in I824. On the other hand, the Rosas Government involved a period of stagnation $(90,000$ inhabitants in I855). But after I855 Buenos Aires

× Buenos Aires and Rosario alone have independent grain markets, though it is differently organized in each case. At Buenos Aires the exporters have entered into direct relations with the producers and eliminated intermediaries. At Rosario they have to use the services of a strong body of agents.

2 The I914 Census does not give reliable details on this point 
resumed its progress, even before the political unity of Argentina was re-established, and has never since relaxed. Its population has doubled almost regularly at intervals of fifteen years: 177,000 in 1869 , 433,000 in $1887,663,000$ in 1895 , and $1,575,000$ in 19I4. The latter figure, in fact, is inadequate. Greater Buenos Aires, including the outlying parts, has really $I, 990,000$ inhabitants.

The site on which the city is built is a regular plateau, sixty-five feet above sea level, cut by flat-bottomed, marshy valleys. The Riachuelo, at the mouth of one of these valleys, provided Buenos Aires with its first port. The low and badly drained lands of the valleys are occupied by the poorest quarters. Their sides, the barrancas, bear the aristocratic residences, and the gardeners have been able to use the sites to great advantage in their plans.

As a whole, the growth of Buenos Aires presents the same feature of regularity, on account of the uniformity of the soil, as the spread of colonization over the plain of the Pampas. The city is distributed in concentric zones, and it is thus a model on a small scale of the distribution of the various types of exploitation on the Pampa which surrounds it. The central nucleus, the business quarter, contains not only the offices, but the warehouses of imported goods. Round this centre, with a radius of one to three miles, are the residential quarters in which the density is greatest (250 to 350 to the hectare). Beyond this the density sinks to less than 200 per hectare and less than fifty on the outskirts. The central quarters developed the maximum density after I900. Those of the first outer zone have gained greatly between 1904 and I909. Since the latter date, the progress of these quarters has been arrested in turn, and the recent growth is mainly in the remote working-class suburbs in the south and on the bank of the Riachuelo. 
Buenos Aires has preserved in its central district, and reproduces in all its outer districts, the primitive draught-board plan of a Spanish colonial city. This plan is not suited to its needs to-day. The rapid growth of the city and its expansion-the mean density is not more than fifty-four inhabitants to the hectare, as against 360 at Paris-complicate the problem of transport. At the present time the city is considering plans for reconstructing its thoroughfares and making diagonal streets, starting from the centre and following the direction of the main streams of traffic. In this way the city would reproduce the fan-wise distribution of railways over the Pampean plain.

Buenos Aires is the intermediary between the provinces and oversea countries. It has three titles to this profitable part. In the first place, it is the chief centre of the import trade. The melchants of the cities in the interior are customers of the Buenos Aires importers, and are closely bound to them by a system of long-term credit. Buenos Aires is, secondly, the centre for the distribution of the European capital which has been used in the development of the country. Lastly, it divides immigrant workers amongst the provinces, just as it divides capital. As an immigration port its position is unrivalled. The efforts that were made to divert part of the immigrants to Bahía Blanca failed, and direct immigration to the Santa Fé province ceased at the close of the first period of colonization, about 1880 . It is also at Buenos Aires that immigrants who are not going to settle in Argentina embark; re-emigration, which is regarded as a national plague by Argentine economists, is another source of profit to the capital. Hence the fortune of Buenos Aires is due in the first place to the close contact between the economic life of Argentina and that of Europe and North America.

But its very growth has led to a gradual change in the part it plays in the interior of the country. In 


\section{WEALTH OF BUENOS AIRES 275}

proportion as its population and wealth grew, it became a great national market. The products of the provinces go to it, not merely to meet its own needs as consumer, but in order to be distributed over the entire country. The figures of the cattle trade on the Buenos Aires market are instructive in this respect. From January to July I9I9 there were I,I30,000 head of cattle sold, 240,000 being for the supply of the capital and 700,000 for the refrigerators. ${ }^{x}$ Of the remainder, I20,000 were bought for fattening and 40,000 by the butchers of other towns. The capital of its own which has accumulated at Buenos Aires is invested either in real estate or in industry, which has found great profit both in the development of local consumption and in the great stock of labour provided by immigration. Buenos Aires is not now content to be merely an intermediary between the country and foreign lands. It contributes by its own resources and work to the task of colonization and the supply of manufactured articles to the agricultural and pastoral districts. It is, finally, a luxurious city, with every opportunity for the men who have grown rich by the rise in the price of lands to spend their income, and providing pleasure for the country folk who come up occasionally, tired of their laborious, rough and solitary existence.

I During the same period the Argentinian refrigerators killed I,490,000 head of cattle. Therefore, about half of these were bought at Buenos Aires. 



\section{BIBLIOGRAPHY}

I give here only the most important and most recent works. A list of the articles I have consulted would be long and uninteresting, while a complete list of those which might have been consulted, and from which information might have been gleaned, is impossible. For a work of this character there is no account of travel, no study of the soil, the climate, or the vegetation, no statistical document or journal or purely historical text, that has not a perfect right to be regarded as a source.

\section{Periodicals.}

Of the periodicals published in Argentina, and partly or wholly devoted to the study of the land and its development, the principal are :-

Boletin del Instituto Geografico Argentino (Buenos Aires, since 1879 ; vol. i, I879, vol. ii, I88I ; one vol. yearly from I88I to I90I; has appeared irregularly since).

Anales de la Sociedad Cientifica Argentina (Buenos Aires, 2 vols. yearly from 1876 ).

Revista de la Sociedad Geografica Argentina (Buenos Aires, only appeared from 1883 to I889).

Boletin de la Academia Nacional de Ciencias de Córdoba (Córdoba, since I874, 23 vols. to I9I8).

The publications of the Buenos Aires and La Plata museums also contain, besides copious anthropological, archæological, palæontological, and historical material, a large number of articles of interest to geographers:-

Anales del Museo Nacional de Historia Natural de Buenos Aires. Begins I864, 25 vols., folio and quarto, to IgI4.

Anales del Museo de la Plata. First series I890-1900, second series from $190 \%$. 
Revista del Museo de la Plata. From I890-I89I, I7 vols. to IgIO-IgII.

All these reviews contain especially articles on the parts of the country which were last explored-Patagonia, Chaco, Misiones. They contain little about the parts that were early colonized, though these are not always the best known.

\section{MAPS.}

The maps published in the eighteenth century (D'Anville's map, I733, in the Lettres édifiantes, Igth collection, Paris, I734: Bellin's map in vol. ii of the Histoire du Paraguay of the R.P.P.F.X. de Charlevoix, Paris, I756, 3 vols., etc.) are based upon information collected by the Jesuit missionaries.

D'Azara's map (I809) shows a remarkable advance.

Important corrections of D'Azara's map are found in Woodbine Parish's map (I838).

Brackebusch's two maps are essential documents: Mapa del interior de la Republica Argentina, por el Dr. L. Brackebusch, I: I,000,000 (Gotha, I835) and Mapa geologico del interior de la Republica Argentina, I : I,000,000 (Gotha, I890).

The results of earlier work have been used in the Atlas de la Republica Argentina construido y publicado por el Instituto Geografico Argentino (Buenos Aires, I894), which includes a list of its sources.

Since that date many maps have been published: maps of the various provinces and surveys drawn up by the railway companies, the Chile Frontier Commission (see Patagonia), the Mines Division (see Natural Regions), and the Ministerio de Obras Publicas (see River Routes). A brief account of the history of Argentine cartography and a list of maps of provinces will be found in Colonel B. Garcia Aparicio, La carta de la Republica (Anuario del Instituto Geografico Militar, i, I9I2, Buenos Aires, pp. I-27).

The Military Geographical Institute has itself published a large number of maps, either on the basis of fresh surveys or by compiling earlier work, chiefly :-

About thirty sheets on the scale I:25,000 (Pampean region) since I904, interesting for studying the relief of the plain. 
"Governacion de la Pampa," I : 500,000 (Estado Mayor, 3A Division, Buenos Aires, I909).

Three sheets on the scale I : I,000,000 (Buenos Aires, Concordia, and Corrientes). Buenos Aires, provisional edition IgII of a map of Argentina on the scale I : I,000,000, which is to comprise twenty-one sheets.

A convenient reference map, though of no scientific value, is the map of the railways, on the scale $I: 2,000,000$, in three sheets, published in I9Io by the Ministerio de Obras Publicas.

\section{Statistics.}

A summary of the chief statistics is published annually in The Argentine Yearbook (from 1902 at Buenos Aires; from Igog at Buenos Aires and London).

The Anuario de la Dirección General de Estadistica, which has appeared since I880 in one, two or three vols. quarto, gives the figures of trade, immigration, agriculture, railways, navigation, etc. (last volume consulted is for I9I4, Buenos Aires, I9I5).

In the third volume of the Amuario for I9I2 will be found a list of the publications of the Dirección de Estadistica. Besides the Anuario the Dirección publishes a bulletin with commercial statistics (last number consulted I8I, "El comercio exterior Argentino en los primeros trimestres de I9I8 y I9I9," Buenos Aires, I9I9). Boletin I76 contains a review of Argentine trade from I9Io to I9I7.

The statistical department of the Ministry of Agriculture, under the direction of $\mathrm{E}$. Lahitte, publishes the Boletin Mensual de Estadistica Agricola (last volume consulted, $\mathrm{xxi}$ IgIg).

\section{General Descriptions. ${ }^{\mathrm{I}}$}

The scientific study of this part of South America may be traced back as far as D'Azara. His observations are

I Besides the publications of the Jesuits, which can easily be consulted, a fairly large number of texts bearing upon the history of colonization have been published or re-published in the nineteenth and the twentieth century. See especially:

Relaciones Geograpicas de Indias (vol. i, I88I ; vol. ii, 1885, Madrid). 
collected in Don Felix de Azara, Voyages dans l'Amérique meridionale, published by Walckenaër (Paris, I809, 4 vols. in $12^{\mathrm{mo}}$ and atlas) and Descripción e historia del Paraguay y del Rio de la Plata, published by D. Agustin de Azara (Madrid, I847, 2 vols. octavo).

The Voyage dans l'A mérique méridionale of Alcide d'Orbigny contains his observations on the Paraná, the province of Corrientes, the Pampa (Parchappe's voyages), and Patagonia (I828). (Historical section, vol. i, Paris, I835; vol. ii, Paris, I839-43; vol. iii, third part, geology, Paris, I842).

Darwin also visited the coast of Patagonia and crossed the Pampa (I833): Narrative of the Surveying Voyage of H.M.S. "Adventure" and "Beagle" . . . vol. iii, as Journal and Researches (London, I839).

Sir Woodbine Parish's work, Buenos Aires and the Provinces of the Rio de la Plata (London, I838), is remarkably wellinformed, and is based upon a thorough study of previous publications and archives.

W. MacKann's Ten Thousand Miles' Ride through the Argentine Republic (London, I855, 2 vols.) is interesting, and the work of a close observer.

Martin de Moussy, Description géngraphique et statistique de la Confédération argentine (Paris, I858, 3 vols. octavo and atlas), is unequal, but full of information.

The work of H. Burmeister, Description physique de la République argentine (Paris, 2 vols., I876), is of little value, and has been overrated.

Richard Napp, Die Argentinische Republik (Buenos Aires, I876, I vol. octavo), includes a valuable chapter by P. G. Lorentz on the flora ("Vegetationsverhaeltnisse Argentiniens," pp. 87-I49).

Anales de la Biblioteca Nacional, Buenos Aires, Publicacion de documentos relativos al Rio de la Plata (from 190o).

Publications of the Junta de Historia $y$ Numismatica Americana (Buenos Aires, 7 vols., octavo, from 1905 to I915).

Valuable notes on some of the most important historical documents will be found in E. Boman, Antiquités de la region andine (see NorthWest Argentina).

The most curious collection of all for the geographer is: Pedro de Angelis, Coleccion de obras y documentos relativos a la historia antigua y moderna de las provincias del Rio de la Plata (Buenos Aires, 1837. 6 vols. octavo, containing many itineraries, journals of expeditions, etc., together with notes by D'Azara). 
The second volume ("Territoire") of the Second recensement de la République argentine (Buenos Aires, 1898) includes a joint geographical study by a number of writers.

Géologie, by J. Valentin.

Climat, by G. G. Davis.

Flore, by E. L. Holmberg.

Some attempt at a general consideration of our geographical knowledge of Argentina has been made by E. A. S. Delachaux, "Las regiones fisicas de la Republica Argentina (Rev. Mus. Plata, xv, I908, pp. I02-I3I).

Our physical knowledge of Argentina has been greatly promoted by the work of the Dirección de Minas. The results are summarized in the Memorias de la Dirección general de Minas, Geologia, e Hidrologia, published from I908 onward (Anales del Ministerio de Agricultura, Sección geologia, mineralogia, y mineria: last volume published for the year 1915, Buenos Aires, vol. xii, No. 2).

Special works are published in the same section of the Anales del Min. Agric., and in the Boletines de la Direccion de Minas, Geologia, e Hidrologia. See, especially, series B (Geologia). These reports and the accompanying maps are the basis of all work on the geography of Argentina. They already cover a great deal of Argentine territory. The work of Keidel, in particular, which is an essential contribution to the geological history of the South-American continent, and that of Windhausen, are largely concerned with physical geography, the study of the relief, and the influence of the climate on the landscape.

A summary of the history of study of the soil of Argentina will be found in E. Hermitte, La geologia y mineria Argentina in IgI4 (Tercer Censo Nacional, vol. vii, pp. 407-494).

As to climate: Buenos Aires Ministerio de Agricultura, Servicio Meteorologico Argentino, Historia y Organisacion, con un resumen de los resultados, preparado bajo la dirección de G. G. Davis (Buenos Aires, I9r4, quarto), dispenses one from consulting any previous works.

There is a very complete bibliography of works on the botany and geographical botany of Argentina in F. Kurtz, "Essai d'une bibliographie botanique de l'Argentine" (2nd edition, Bol. Acad. Nac. Ciencias Córdoba, xx, I915, pp. 369467). 
There is a convenient summary of our knowledge of the primitive population in Felix F. Outes and Carlos Bruch, Los aborigenes de la Rep. argentina (Buenos Aires, I9Io).

\section{North-West Argentina.}

The most complete general work on irrigation is that of E. A. Soldano, La irrigación en la argentina (Buenos Aires, Igro, octavo). See also C. Wouters, "La irrigación en el valle de Lerma" (An. Soc. Cient. Argentina, lxvi, I908, pp. II7-I45).

The best description of the Puna de Atacama and the country of the Valles is in Eric Boman, "Antiquités de la région andine de la Republique Argentine et du désert d'Atacama" (Mission scientifique G. de Crequi, Montfort, et E. Senechal de la Grange, Paris, I908, 2 vols.).

L. Brackebusch, "Ueber die Bodensverhaeltnisse des nordwestlichen Teiles der Argentinischen Republik mit Bezugnahme auf die Vegetation" (Petermann's Mitteilungen, I893, p. I53) is a general description of the whole of northwestern Argentina; but Brackebusch's description of his journey, "Viaje a la provincia de Jujuy" (Bol. Inst. Geog. Argent., iv, I883, pp. 9-I7, 204-2II, and 2I7-226) is fresher and more useful.

I have mentioned in the note to p. 40 Bodenbender's work on the province of La Rioja.

Of the various articles, from all quarters, on North-Western Argentina the following may be noticed:-

J. B. Ambrosetti, "Viaje a la Puna de Atacama de Salta a Caurchari" (Bol. Inst. Geog. Argent., xxi, I900, pp. 87-Ir6).

F. Kühn, "Descripción del camino desde Rosario de Lerma hasta Cachi" (Bol. Inst. Geog. Argent., xxiv, I9Io, pp. $42-50)$.

H. Seckt, " Contribución al conocimiento de la vegetación del Nordeste de la Rep. Arg.-Valles de Calchaqui y Puna de Atacama" (An. Soc. Cient. Arg., lxxiv, I9I2, pp. I85225).

Juan F. Barnabe, "Informe sobre el distrito minero de Tinogasta" (An. Min. Agric., Seccion Geol. Mineralogia y Mineria, x, No. 4, Buenos Aires, I9I5).

On the Puna de Atacama: 
L. Caplain, "Informe sobre el estado de la mineria en el Territorio de los Andes" (An. Min. Agric., Seccion Geol. Mineralogia y Mineria, vii, No. I, Buenos Aires, I9I2).

On the sub-Andean chains :-

Guido Bonarelli, "Las Sierras subandinas del Alto y Aguaragüe y los yacimientos petroliferos del distrito minero de Tartagal" (ibid., viii, No. 4, Buenos Aires, I9I3). See also Dirección General de Minas, Geol., e Hidrol, Boletin, series B, No. 9 (Buenos Aires, I9I4).

On the Chaco Salteño:-

L. Arnaud, "Expedición al Chaco" (Bol. Inst. Geog. Argent., vi, I885, pp. 20I-2I0).

On the part of the San Luis province that lies in the zone of the scrub :-

Avé-Lallemant, "Datos orograficos e hidrograficos sobre la Provincia de San Luis" (Bol. Inst. Geog. Argent., v, I884, pp. I9I-I96, and 222-224), and "Apuntes sobre represas y baldes en San Luis" (An. Soc. Cient. Arg., xi, I88I, pp. I78I88).

A. L. Cravetti, "Investigación agricola en la Provincia de San Luis" (Buenos Aires, I904, An. Min. Agric., Sección Agric., Botanica, y Agronomia, vol. i, No. 5).

On the scrub south of Mar Chiquita:-

H. Frank, "La repoblación forestal en la region de la Mar Chiquita" (Bol. Dep. gen. Agric. y Ganaderia, Prov. Córdoba, ii, I9I2, pp. 52-57), and "Contribución al conocimiento de la Mar Chiquita" (ibid., pp. 87-Ior).

\section{Tucumán and Mendoza.}

On Tucumán see Emilio Lahitte, La industria azucarera, apuntes de actualidad (Buenos Aires, I902).

The best source of the economic history of the sugar industry is the file of the Revista azucarera ("organa de los cultivadores de caña y fabricantes de azucar," Buenos Aires).

On Mendoza, "Investigacion vinicola" (Buenos Aires, 1903, Anales, Min. Agric., Sección Comercio, Industrias, y Economia, i, No. I). 


\section{Forestry INDUSTRIES.}

Rudolf Leutgens, " Beiträge zur Kenntniss des QuebrachoGebietes in Argentinien und Paraguay" (Mitteil. Geogr. Ges. Hamburg, xxv, I9II, pp. I-70).

\section{Patagonia.}

\section{A. The Tableland.}

Apart from Villarino's journey on the Rio Negro in the eighteenth century, the first journey across the Patagonian tableland is that of G. Chaworth Musters, At Home with the Patagonians (London, I87I).

In the early volumes of the Bol. Inst. Geog. Argent. will be found the results of various explorations between I 878 and 1885 by Argentine travellers.

With this group of documents, which provided the first material for his conclusions, we may associate the geological studies of Florentino Ameghino, "L'âge des formations sédimentaires de Patagonie" (An. Soc. Cient. Argentina, 1, I900, pp. Io9-I30, I45-I6o, and 209-229; li, I90I, pp. 20-39 and 65-9o ; lii, I90I, pp. I89-I97 and 244-250 ; liii, I902, pp. I6I-I8I, 220-249 and 282-342) and "Les formations sédimentaires du crétacé supérieur et du tertiaire en Patagonie" (An. Mus. Nac. Buenos Aires, series ii, vol. viii, I906, pp. I-568).

On the southern part of Patagonia, south of $50^{\circ} \mathrm{S}$. lat. :-

Svenska Expeditionen till Magellanslaenderna (Wissenschaftliche Ergebnisse der Schwedischen Expedition nach den Magellans Laendern, I895-I897, unter Leitung von Dr. Otto Nordenskjoeld, Band I, Geologie, Geographie und Anthropologie, Stockholm, I907).

On the Magellan region and that of the Santa Cruz:Reports of the Princeton University Expeditions to Patagonia, r896-9, i, J. B. Hatcher, Narrative of the Expeditions, Geography of Southern Patagonia (Princeton and Stuttgart, I903).

On the Rio Negro district:-

S. Roth, "Apuntes sobre la Geologia y la Paleontologia de las Territorios del Rio Negro y Neuquen" (Rev. Mus. Plata, ix, I899, pp. I4I-I96). 
Of more recent works we must especially notice those of the engineers of the Dirección de Minas:-

R. Stappenbeck y F. Reichert, "Informe preliminar relativo a la parte sudeste del Territorio del Chubut" ( $A n$. Min. Agric., Sección Geol. Mineral., y Minas, vol. ix, No. I, Buenos Aires, I909).

Ricardo Wichmann, various studies of the eastern part of the plateau of the Rio Negro (ibid., xiii, Nos. I, 3 and 4 , Buenos Aires, I9I8 and I9Ig).

A. Windhausen, studies on the Rio Negro and the Neuquen (ibid., x, No. I, Buenos Aires, I9I4). The geological results of Windhausen's work are summarized in articles that appeared in the American Journal of Science (4th series, xlv, I9I8, pp. I-53) and in the Bol. Acad. Nac. Ciencias Córdoba (xxiii, I9I8, pp. 97-I28 and 319-364).

We must add G. Rivereto, "La valle del Rio Negro" (Bol. Soc. Geologica Ital., xxxi, I9I2, pp. I8I-237, and xxxii, I9I3, pp. IOI-I42).

\section{B. The Andes.}

Numerous articles in the Bol. Inst. Geog. Argent. and the An. Soc. Cient. Argentina, immediately after the military expedition of 1879-I880 (Host, Avé-Lallemant, etc.).

A detailed study of the Andean region was undertaken at the time of the frontier-quarrel between Argentina and Chile, and this led to a number of publications. The work done by the Argentinians under F. P. Moreno is used in Frontera Argentina-Chilena, Memoria presentada al tribunal nombrado por el Gobernio de su Majestad Britanica (London, I902, 2 vols. quarto, I vol. maps, and I vol. photographs), and in the Breve Replica a la memoria Chilena (London, I vol. quarto, I902). See a summary of the results in L. Gallois, "Les Andes de Patagonie " (Annales de Géographie, $\mathrm{x}$, I90I, pp. 232-259).

In the Revista and the Anales of the La Plata Museum will be found part of the research made during this period (I897-1900) by Argentine experts; especially the work of Burckhardt and Wehrli on the Neuquen Cordillera. The Chilean work which served as the basis of the Statement presented on behalf of Chile in reply to the Argentine Report 
(London, Igo2, 4 vols. and 2 vols. as appendices) is, on the whole, less valuable.

Of later travellers we must mention P. D. Quensel, "On the influence of the Ice Age on the continental watershed of Patagonia" (Bull. Geol. Inst. Univ. Upsala, ix, I908-9, pp. 60-92), and "Geologisch-petrographische studien in der Patagonischen Cordillera" (ibid., xi, I9I2, pp. I-II4).

Very important surveys in the Cordillera and on the plateau of the Rio Negro were made under the direction of Bailey Willis (Northern Patagonia, Ministry of Public Works, Bureau of Railways, Argentine Republic; text and maps by the Comisión de Estudios hidrologicos, Bailey Willis Director, I9II-I9I4, New York, I9I4, I vol and atlas).

On the Patagonian forest (Argentine slope from $40^{\circ} \mathrm{S}$. lat. to Cape Horn) see Max Rothkugel, Los Bosques Patagonicos (Minist. Agric., Dirección Gen. Agric. y Defensa Agricola: Officina de Bosques y Yerbales, Buenos Aires, IgI6).

\section{The Pampean Region.}

The occupation of the western part of the Pampa between I875 and I880 led to a fairly large amount of research. The most important work is the Informe oficial de la Comision cientifica agregada al Estado Mayor General de la Expedición al Rio Negro, vol. iii, Geologia, by Dr. Ad. Doering (Buenos Aires, I882). We must also notice G. Avé-Lallemant, "Excursión al Territorio indio del Sud" (Bol. Inst. Geogr. Argent., ii, I88I, pp. 4I-49) ; D. Dupont, " Notas geograficas sobre el païs de los Ranqueles (Bol. Inst. Geog. Argent., I790, pp. 47-56); and Est. Zeballos, Descripción amena de la Republica Argentina, vol. i, Viaje al païs de las Araucanos (Buenos Aires, I88I).

Of general works on the Pampa and the Pampean deposits :

Fl. Ameghino, La formación Pampeana (Paris and Buenos Aires, I88I), and "Las formaciones sedimentarias de la región litoral de Mar del Plata y Chapalmalan" (An. Mus. Nac. Buenos Aires, series ii, vol. x, I908, pp. 348-428).

G. Bodenbender, "La cuenca del valle del rio Primero en Córdoba: Descripción geologica del valle del rio Primero desde la Sierra de Córdoba hasta la Mar Chiquita" (Bol. 
Acad. Nac. Ciencias Córdoba, xii, I89o, pp. I-54); and "Die Pampa Ebene in Osten der Sierra von Córdoba in Argentinien" (Petermann's Mitteilungen, 1893, pp. 20I-237 and 258-264).

Santiago Roth, "Beobachtungen ueber Entstehung und Alter der Pampasformationen in Argentinien" (Zeitschrift der Deutschen Geol. Ges., xi, I888, pp. 375-464) ; "Beitrag zur Gliederung der Sedimentablagerungen in Patagonien und der Pampas Region" (Newes Jahrbuch für Min., Geol., und Paleont., Beilage, Band xxvi, Stuttgart, Ig08, pp. 92-I50); and "La construcción de un Canal de Bahía Blanca a las provincias andinas bajo el punto de vista hidrogeologico" (Rev. Museo de la Plata, xvi, Igog).

Nouvelles recherches sur la formation pampéenne et l'homme fossile de la Republique argentine. A collection of scientific articles published by R. Lehmann-Nitsche (Rev. Mus. Plata, xiv, I907, pp. I43-488), which contains, especially, one by C. Burckhardt, "La formation pampéenne de Buenos Aires et Santa Fé," and one by Ad. Doering, "La formation pampéenne de Córdoba."

Ales Hrdlicker, Early Man in South America (Smithsonian Institution, Bull. 52, Washington, I9I2-geological part by Bailey Willis).

On the district of the Central Pampa, R. Stappenbeck, "Investigaciones hidrogeologicas de los valles de Chapalco y Quehuë y sus alrededores" (Min. Agric., Dir. Gen. Minas, Geol., e Hidrol., Bol. No. 4, Buenos Aires, 19r3).

On various points in detail one may consult :Lavalle y Medici, "Las nivelaciones de la Provincia" (Bol. Inst. Geog. Argent., vii, I866, pp. 57-7r).

P. A. Bovet, El Problema de los Medanos en el Pais (Buenos Aires, I9I0).

R. Velasco, "Los Medanos de la Provincia de Córdoba" (Bol. Dep. Gen. Agric. y Ganaderia, Prov. Córdoba, i, pp. I55I73).

Among descriptions of an economic character, which are generally of poor value, we must make an exception in favour of Emile Daireaux, La vie et les moeurs a la Plata (Paris, I889).

A few useful notes on colonization will be found in Teod. Morsbah, "Estudios economicos sobre el Sud de la Provincia 
de Buenos Aires" (Bol Inst. Geog. Argent., ix, I888, pp. I43I5I) and in E. Segui, "La provincia de Buenos Aires" (Bol. Inst. Geog. Argent., xix, I898, pp. 4I9-440).

A very useful summary of the results of a general inquiry into agriculture will be found in "Investigación agricola en la Rep. argent" (Anales Min. Agric. Agronomia, vol. i, No. I, 2 and 3, Buenos Aires, I904: "Preliminares," by Carlos D. Girola, "Investigación agricola en la region septentrional de la Provincia de Buenos Aires," by Ricardo J. Huergo, and "Investigación agricola en la Provincia de Santa Fé," by Hugo Miatello).

With this inquiry is associated G. D. Girola, El cultivo del trigo en la provincia de Buenos Aires (Buenos Aires, I904).

Agricultural censuses have been taken repeatedly. For I888 F. Latzina, L'agriculture et le bétail dans la République argentine (Paris, I889). For I895 (Secundo censo, see Population) the results are given in C. P. Salas, Bureau central de Statistique de la province de Buenos Aires and L'agriculture, l'élevage, et le commerce dans la province en I895 (La Plata, I897; maps by Delachaux). For I908, Censo agro-pecuario nacional. La ganaderia y la agricultura en I908 (Buenos Aires, 3 vols. quarto, I909). Vol. iii contains a series of monographs dealing not only with the Pampean region, but the economic history of the whole country.

For IgI4 (Tercer censo, see Population) the publication of vol. v, relating to agriculture, is unfortunately delayed. There is also available a census of cattle made in I9I5 for the Buenos Aires province, Provincia de Buenos Aires, Min. Obras Publicas, Censo Ganadero (IgI6).

\section{Io. The RaIlways.}

For the history of the railways see Rebuelto, "Historia del desarollo de los ferrocarriles argentinas" (Bol. Obras Publicas, vol. v, I9II, pp. II3-I72, vol. vi, I9I3, pp. I-48 and 8 I-IIO, and vol. viii, I9I3, pp. I-32), and the entire series of the Boletin de Obras Publicas.

A sort of annual of the Argentine railways has been published every year since 1906 under the title Killik's Argentine Railway Manual (London, I vol. with map, last issue IgI8). 


\author{
Ir. The Paraná.
}

E. A. S. Delachaux, "Los problemas geograficos del territorio Argentino" (Rev. Univ. Buenos Aires, rgo6, v), includes a study of the floods of the Paraná.

The chief source is the memoir of Repossini, "Memoria sobre el rio Paraná" (Bol. Obras Publicas, vol. vi, I9I2, pp. I4I-I68 and 254-264, vol. vii, I9I2, pp. 3I-48 and I63-186, and vol. viii, I913, pp. 33-99). It contains on a reduced scale the map issued by the Ministry of Public Works, which is not available in France. The defect is supplied by the English Admiralty Charts, "Rio de la Plata," I869 (No. 2544 in the Catalogue of Admiralty Charts), and “River Paraná," parts i, ii, iii, iv, v, and vi of 1905 (Nos. I982/A and I982/B).

There is an interesting economic summary in W. S. Barclay, "The River Paraná, an economic survey" (Geogr. Journal, xxxiii, I909, pp. I-Io).

On the estuary:-

Alej. Foster, "Regimen del Rio de la Plata y su corrección " (An. Soc. Cient. Argent., lii, rgor, pp. 209-234).

G. Rovereto, "Studi di geomorfologia argentina," ii, "Il rio della Plata” (Bol. Soc. Geol. Ital., xxx, IgrI).

\title{
I2. Population.
}

Besides municipal and provincial censuses, there have been three general censuses:

First census made in I869, one folio volume published in I872. I have only been able to consult Oficina del Censo. Informe sobre la operación y resultado del Primer censo argentino (Buenos Aires, 1870, octavo).

Second census of the Argentine Republic, May Io, 1895 ( 2 vols. quarto, Buenos Aires, 1898).

Tercer Censo Nacional levantado el $\mathrm{I}^{\circ}$ de junio de IgI4 (ro vols. quarto, Buenos Aires, IgI6-I9I7). Only the fifth volume, on agriculture, is not yet to hand.

A geographical interpretation of the distribution of the population was attempted by E. A. S. Delachaux, "La población de la Rep. Argent." (Rev. Univ. Buenos Aires, iii, I905). 



\section{INDEX}

Abipones, the, 24

Acequia, the, 45, 69, 83

Aconcagua, 19, 38, 59, 70, 7 I

Eolian deposits, 21, 124, 170

Agricultural Centres Law, the, 202

Aguadas, 61, 210

Algarrobas, 39, 54, 64

Alhuampa, II 3

Alumine, the, 128, 129

Ambrosetti, J. B., I36, 282

Ameghino, F., I68

Andalgala, 42

Andes, the Argentine, 19, 37, 46, $54,57,70,126$

Andes, the Patagonian, I9, 120, I26, 129

Añecon, 122, 151

Antofágasta, 54, 55

Apipé rapids, the, 239

Apostoles, I I 6

Araucanians, the, 24, I21

Argentine hydrographic service, 254

Arrieros, the, 51, 216, 217

Arroyo del Rey, 26

Asses, trade in, 53

Atamisqui, 97, 98

Atuel, the, 81, 84

Azcarate, 5I, 52

Bahía Blanca, 25, 32, 148, 155 , I64, I68, 173, 198, 223, 227 , 271

Bajada Grande, the, 242, 243

Bamboo, 133

Bañados, the, $62,63,67,97,98$, Ior

Barra del Indio, the, 253

Barrancas, I7, 245

Basalt, 122, 125, 149
Basques in Argentina, 183, I 86

Bellavista, 246

Bellville, 167,188

Bermejo, the, 40, II 5

Bodegueros, 87-90

Bodenbender, G., 40, 57, 168, 286

Bolivia, relations with, $48,50,52$, 53,70

Boman, E., 47, 282

Brackebusch, L., 48, 54, 278, 282

Brazil, 109, I 16, 182, 235

Breeding, 22, I31, I79, I88, I89

British Navy in Argentine waters, $238,24,252$

Buenos Aires, 17, 29, 30, 32, 57 , I09, I1 2, I55, I59, I64, I 84, 209, 218, 220, 239, 254, 259, 272-275

Burruyacu, Sierra de, 72, 73

Calchaqui, 48, 54

Caldenes, 163

Cañadas, 107

Cañadones, 122-14I

Candelaria, I10, I 16

Cañeros, the, 74, 75

Carcaraña, the, I 7 I, 21 2, 246

Carilaufquen, the, I4I

Carmen, 130

Carri Lauquen, Lake, I 28, I 51, 157

Catamarca, 3I, 43, 45, 55, 80

Cattle, creole, 22, I31, 179-183, I 89

Cattle, pedigree, 22, I88, I 89

Cattle fairs, 209

Cattle trade, the, $48,50,53,66$, 8o, I3I, I 79-189, 206-2n8

Catuna, 62 291 
Central Argentine Railway, 76, I9I, 220, 225

Central Cordoba, 74, 76, 91, I04, 221

Central Norte Railway, I 4

Cerco, the, 63

Cerro Payen, the, $119, I_{3} 6$

Cerros Colorados, I50, I5I

Chaco, the, 32, 78, 96, 104-II5

Chaco, Salteño, the, 58-6o

Chamical, 62

Chañares, 163

Charcoal-burners, I 12

Chicago and Buenos Aires, 17

Chile, relations with, 25, 29, 30, $48,49,53,54,57,134,137,138$, 204, 205, 210

Chile road, the, 210, 213

Chilean flour, 79

Chiriguanos, the, 79

Chivilcoy, I90, I94, 195, 21 2, 263

Choele Choel, I33, 134, I49

Chosmalal, 120, 137, 144

Chubut, the, I38, I 40,155

Climate, 46, 70, 71, 72, 77, 80, 92, I I9, I 20, 139

Coilrue, the, 127

Colalao del Valle, 42

Colastiné, 226, 253

Colonia, 25I, 252

Colonies, the, I91, I93, I95, I96

Colonization Companies, 202

Colonos, 75

Colorado, the, 172

Conlara, 178

Cordillera, the, I9, 20, 48, 8I, I2I, 126, 129

Córdoba, 29, 33, 50, 57, 164

Córdoba, Sierra de, 209

Corrientes, 32, 49, 102, 107, 108, I 89, 215, 257, 269

Costa, the, $4 \mathrm{I}, 42,60$

Cruz Alta, 73, 74, 75

Cuarto, the Rio, 25, 2 I I

Cuenca Vidal, I 55

Cumbre Tunnel, 222

Cuyo, 79, 85, 86, 96

Cypresses, 127

Daireaux, E., I87, I93, 287
Dairies, 186, 190, 193

Dams, 69-70

Darwin, C., 23, 123, 133, 170, 217 , 280

D'Azara, F., 25, 28, 49, I02, I74, I $80,212,279,280$

Dead valleys, 122,129

Demarcación, 44

Diamante, 248, 249

Diamante, the, $8 \mathrm{I}, 84$

Diez y seis de Octubre, I20, 144

Doering, A., 168, 286

Dolores, 178

D’Orbigny, A., I30, I31, 133, I42, I $80,236,237,280$

Drainage, 83

Drought, 65, 66, I05, 120

Dulce, the Rio, 97,98

Dunes, I73, 174, I81

Durham cattle, 189,207

English Bank, the, 252

Entre Rios, 169, I82, 186, 194

Epecuen Lake, 212

Exhibition, San Francisco, 7

Falda, the, 73, 74

Famatina, Sierra de la, 40

Fiords, the Patagonian, 20, 128

Flax, 176, 196, 197

Floods, 97, 99, 211

Floods on the rivers, $240,24 \mathrm{I}$

Forests, 23, 96-1 I 8

Forts, the early, 26, 27

Frontiers, early, 25

Funes, Dean G., 30, I79

Galeria, the, 218

Gallegos, I20, I21, 136

Garcia, Colonel, 27, I82, I83, 210

Garrapate, the, 22, I89, 207

Gauchos, 218

Gauge, differences of, 22I, 222, 231, 232

General Lavalle, 165

Geological formations, 40, I2I, I22, I24-126, I29, I66, I68

Glaciers, the Patagonian, 19, 36, 123, 128,129

Gold, 138 
Goods, traffic, analysis of, 228-23I Granite, I21, 125, 149

Guapichas, 54

Guayra, the, 246

Harvest, labour and the, 266

Helms, A. Z., 51

Hides, I 78-1 80

Holmberg, E. L., 23, 28I

Hrdlicka, A., I68, 287

Huari, 56

Hutchinson, F. J., 50

Immigration, 9, I16, 137, I91, 263,264

Indians, relations with the, $24-28$, 47, $131-135$

Indians, the Patagonian, 131-135

Ingeniero White, 226

Intrusos, 139, 157

Invernadas, the, $51,53,60,65,183$

Irrigation, 36, 4I-46, 61, 64, 74, $83-86,144,154$

Itinerary of author, 6

Ituzaingo, 246, 257

Japan, trade with, 8

Jegou, A., 205

Jerked meat, II 5

Jesuit missions, I 10

Jujuy, 38, 56, 77

Junin, 194

Labour-supply, 76, 77, 79, 88, 108-I I I

Lacar, Lake, I 44

Land-ownership, 6I, 20I-203

Land, speculation in, 201

Lanin, Mount, 128-147

Larch, the, 146

La Rioja, 32, 33, 59, 80, 209

Ledesma, 78

Lenga, the, 127

Lima, 29, 48

Limay, the, 120, 123, 124, 130, I 46,154

Lincoln sheep, 184

Los Sauces, 4 I

Lucerne-farms, 53, 67, 155, 176178 , 196
Lumbrera, Sierra de la, 58, 70, 77

Mackann, W., I80, 280

Maize, 71, 192-194, 197, 198, 230

Mallin, 124, 125, 142, 151

Manantiales, 142, 148

Maquinchao, 148, I50, I5I, I53, 158

Mar Chiquita, 113, 162, 173, 176, I9I

Markets, Argentine, 203-210

Martin Garcia, 166, 251, 253

Matacos, the, 79

Maté, 33, 109-112, II 7

Matto Grosso, 11 7, 235

Mayten, 128

Mejia, Ramos, 224

Mendoza, 19, 32, 33, 50, 57, 79$93,218,270,271$

Merced, the, 61,67

Mercedario, 19

Merino sheep, I 84

Mesopotamia, the Argentine, I8

Miatello, 176

Migrations of cattle, $65,143,157-$ 159

Migrations of indigenous population, 264-267

Misiones, 33, 109-112, I I 5

Molle, 127

Monte, the, 22, 96

Montevideo, 238, 25I

Moussy, Martin de, 25, 50, 204, 210

Muleteers, the, 216-7

Mule-trade, the, 49, 5I-2, 53, 55

Nahuel Huapi, Lake, I20, I26, 127, I 30, 132, I33, I 44, 225, 245,247

Navigation, statistics of, 258

Negro, the Rio, 32, 80, I 19, I2I, I30, I53

Negroes captured, I3I

Neuquen, the, 129, 130, 137, 138, I53

Oases, 36, 4I, 86

Oats, 199

Obrajes, the, 103-105, 107 
Olavarria, 194

Olta, 62

Omber, the, 163

Ortiz Bank, the, 252

Otway Water, x29, I36

Pagancillo, 40

Pampa, the, I7, 21, 33, I6I-208, 26I, 262

Pampa, extent of the, 102

Parabolic tariffs, 226

Paracao, 248

Paraguay, 109, xxo, 236, 269

Paraguay, the river, I $16,165,235$, 241,247

Paraisos, I75

Paraná, the, I7, 26, I I I, I I 2, I 7 I, $214,234,236-50$

Paraná de las Palmas, the, 250, 252, 253

Parana Guazu, the, 25I

Parana Mini, the, 253

Parish, Sir Woodbine, 30 , 100, 130 , I 82,2 I 3,2 I $5,26 \mathrm{I}, 280$

Paso Paraguayo, the, 250

Pasto dulce, 23, 24, 183

Pasto duro, 23, 24, 183

Pasto fuerto, 23

Patagones, I53, I54

Patagonia, II9-160

Pehuenches, the, 24, 131

Peru, relations with, 28, 29, 49, 5 I

Peru road, the, 209, 210, 213,214 , 216

Piedra Blanca, 43

Pine forests, 109

Plata, Rio de la, 28, 29, 234, 239

Playa Honda, the, 252, 253

Poma, 56

Poncel, B., 31, 53

Population, growth of, $26 \mathrm{I}-263$

Ports, 225

Portuguese, relations with the, 235

Posadas, I I I, II6, 242, 248, 249

Potatoes, 205

Pozos del Barca Grande, 253

Protectionism, 93, 94

Puerto Belgrano, 232

Pumpkin, the, Ioo

Puna, the, 37,38
Puna de Atacama, 47, 48

Punta Arenas, I36

Quebracho, the, 23, 96, 103, 256-7

Quebracho Herrado, 26

Quebradas, 38, 4I, 53

Quetriquile, I5I

Quinto, the Rio, 26

Quiroga, 59

Railways, 74, 76, 91, I04, I I4, I9I, 2II, 220-233

Railway tariffs, 226

Rainfall, 21, 38, 39, 71, 72, 80, I20-I 21,164

Ranqueles, the, 24, I3I

Refrigerators, I43, 187, 188, 209

Repossini, 254

Represa, the, 64, 210

Riachucho, 247

Rincones, 180

River-floods, 240, 24I, 243

River-traffic, 235-258

Roads, 210-220

Roca, General, 26, 27

Rosario, 92, 164, 171, 173, 191, $215,22 I, 239,245,253$

Rosario de Lerma, 55, 56

Rosas, General, 30, 238

Saladeros, I84, I 89

Salado, the, 23, 26, I I 2, I 7 I

Sali, the, 69, 77

Salitral, 124, 149

Salt Lakes, the, 24

Salt Road, the, 212

Salta, 29, 32, 33, 38, 46, 48, 5I, $59,70,214,218$

San Cristobal, II4

San Feliciano, 248

San Javier, I Io, 114, 249

San José, I 16,134

San Juan, 19, 32, 33, 50, 66, 79, 82

San Lorenzo, 249

San Luis, 33

San Pedro, 78, 289, 250

San Rafaël, 80, 81, 82, 172, 177

Sancho, 7 I

Santa Cruz, the, I20, I21, 122 
Santa Fé, 26, 52, I12, I14, I75, 191, 196, 198, 253

Santa Maria, 55, 56, 77

Santiago del Estero, 26, 28, 50, $60,77,97$, I I 3

Saw-mills, 106-8

Scrub, the, 22, 96

Seasonal migrations, 266

Selective breeding, 21, 179, 188, I 89

Sheep-breeding, I39-144, I83-186

Shipping, 236, 740, 253-259

Sierra de los Llanos, 59-63, 67

Sierra d'Ulapes, 66

Somuncura, 122, 152

Spaniards, the early, 28, 29, $4^{8}$

Stage-coaches, 2 Io

Straits of Magellan, 129

Sugar-industry, the, 69-79

Suerte de agua, the, 85

Tablelands, the alluvial, 17,37

Tandil, Sierra de, 25, 172, 179, 182, 184,190

Tannin, 102, 105, 106, 107

Tehuelches, the, I3I

Texas fever, 22, I89

Teran, M. J. B., 7

Tercero, the Rio, $2 I_{1}, 2$ I 3

Tierra del Fuego, I28, 140

Tinogasta, $4^{8}$

Tobacco, IoI

Tobas, the, 24,26

Toma, the, 63

Tosca, the, 123, 172, 173, 178

Tostado, II 4

Trans-Andean railway, 220, 22I, 222

Transhumation, $143,156-159,182$

Transport, evolution of, 215-220, 228

Travelling, early difficulties of, 2II-219, 237-238

Travesias, the, $52,60,142,21$ I

Tronador, Mount, 128, 147

Troperos, the, 217-19

Tucumán, 29, 32, 33, 69-79, 218, $22 \mathrm{I}, 270,27 \mathrm{I}$

Tunuyan, the, 81,82
Tupungato, 19

Turno, the, 44, 85, 86

United States, comparison with 32,34

United States, trade with, 8

Urban centres, 268, 269

Urquiza, 26, I80, 215

Uruguay, I 6

Uruguay, the river, I10, 235, 238, 259

Useless Bay, 129

Valcheta, 122, 123, I 49, I 50, I 53

Valle de Lerma, 48, 54

Valle Viejo, 43, 45

Valles, $37-4^{8}$

Vegas, 54, I 44

Veinte cinco de Mayo, 194, 262

Ventana, Sierra de, I 72, I82, I98, 199

Villa Concepción, I ro

Villa Maria, II3, 213

Villa Mercedes, 25, 66, II3, I64, I74, I77, 207, 221

Villa Paraná, 245

Villa Rica, I Io, I I I

Villarino, I 30,133

Villa Urquiza, 244

Vilque, 56

Viñatores, 87-93

Vineyards, 80-93

Volcada de agua, 45

Volcanic eruptions, 122, 125

Wagons, travel by, 216, 217

War, the European, effect of, 8

Water-power in Patagonia, 146

Water-rights, 43-46, 6r, 64, 84-86

Water-supply, 36, 38, 39, 4I-46, $6 \mathrm{I}, 64,72,83-86, \mathrm{I} 4 \mathrm{I}, \mathrm{I} 54, \mathrm{I} 8 \mathrm{I}$

Welsh in Patagonia, 138

Wheat, 190-192, 194, 198, 199, 230

Wheelwright, 22 I

Wild cattle, I79-I 8 I

Willis, Bailey, I38, I46, I47, I52, I 7 I

Wind, action of the, 20, 124, 170 
Wine-industry, the, 80-95

Wool, I39, I 83-185

Yerbales, the, 49, Io9-II2, II5, I 17
Yguassu, the, 242, 246, 257

Zapala, 156, 158

Zeballos, 204, 213

Zonda, the, $4 \mathrm{I}$ 



